Naoko Sonoda Editor

New Horizons

for Asian

Museums and

Museology

Springer Open 
New Horizons for Asian Museums and Museology 

Naoko Sonoda

Editor

New Horizons for Asian

Museums and Museology

照 Springer Open 


\author{
Editor \\ Naoko Sonoda \\ National Museum of Ethnology \\ Suita, Osaka, Japan
}

\author{
ISBN 978-981-10-0885-6 \\ ISBN 978-981-10-0886-3 (eBook) \\ DOI 10.1007/978-981-10-0886-3
}

Library of Congress Control Number: 2016943142

(C) The Editor(s) (if applicable) and the Author(s) 2016. This book is published open access.

Open Access This book is distributed under the terms of the Creative Commons AttributionNonCommercial 4.0 International License (http://creativecommons.org/licenses/by-nc/4.0/), which permits any noncommercial use, duplication, adaptation, distribution and reproduction in any medium or format, as long as you give appropriate credit to the original author(s) and the source, provide a link to the Creative Commons license and indicate if changes were made.

The images or other third party material in this book are included in the work's Creative Commons license, unless indicated otherwise in the credit line; if such material is not included in the work's Creative Commons license and the respective action is not permitted by statutory regulation, users will need to obtain permission from the license holder to duplicate, adapt or reproduce the material.

This work is subject to copyright. All commercial rights are reserved by the Publisher, whether the whole or part of the material is concerned, specifically the rights of translation, reprinting, reuse of illustrations, recitation, broadcasting, reproduction on microfilms or in any other physical way, and transmission or information storage and retrieval, electronic adaptation, computer software, or by similar or dissimilar methodology now known or hereafter developed.

The use of general descriptive names, registered names, trademarks, service marks, etc. in this publication does not imply, even in the absence of a specific statement, that such names are exempt from the relevant protective laws and regulations and therefore free for general use.

The publisher, the authors and the editors are safe to assume that the advice and information in this book are believed to be true and accurate at the date of publication. Neither the publisher nor the authors or the editors give a warranty, express or implied, with respect to the material contained herein or for any errors or omissions that may have been made.

Printed on acid-free paper

This Springer imprint is published by Springer Nature

The registered company is Springer Science+Business Media Singapore Pte Ltd. 


\section{Preface}

The international symposium "New Horizons for Asian Museums and Museology" was held at the National Museum of Ethnology, popularly known as Minpaku, Japan, February 21-22, 2015. This symposium aimed to build a new framework for sustainable international cooperation which would contribute to the future development of museums, promoting the network of museums and museology that had already been formed.

Minpaku was founded in 1974 as an Inter-University Research Institute in order to serve as a research center for cultural anthropology and related disciplines, according to the Japanese government higher research and education policy. The exhibitions were opened to the public in 1977. Our 60 researchers have conducted fieldwork on societies, cultures, and socio-cultural changes caused by globalization at sites worldwide.

Every year, we also organize 40 research projects and 20 international symposia, and receive more than 1,000 scholars from overseas and Japan to join these activities. In the Asia-Pacific region, this museum may be the largest research center for socio-cultural anthropology and ethnology. We provide graduate education at the doctoral level.

To pursue deeper understanding of cultures and values, our staff collect and preserve ethnographical, audio-visual, and documentary materials. Minpaku has collected upwards of a half million artifacts and audio-visual materials. And around 10,000 artifacts are exhibited in the permanent gallery and 700 films are offered in our Videotheque. Our permanent and temporary exhibitions receive over 200,000 visitors each year.

Since 1994, we have been organizing an international training course on museology with financial support by the Japan International Cooperation Agency (JICA) and in collaboration with the Lake Biwa Museum, Japan. The course covers a wide range of museum activities, from collection planning, acquisition, documentation, conservation, exhibition, education and public relations. More than 200 museum professionals from all over the world have participated in the course.

In fiscal 2012, Minpaku launched a 3-year project called "New Horizons in Asian Museums and Museology." This was sponsored by the Japan Society for the 
Promotion of Science (JSPS), and has the objective of establishing a common platform for sharing knowledge and experience, whereby museum specialists and researchers in Asian countries can communicate with each other about their activities and research results.

The international symposium "New Horizons for Asian Museums and Museology" was an opportunity to present outcomes from the 3-year project, and to evaluate our 20-year-long effort of the training course, and to present new perspectives on international cooperation and human resource development for museums and museology. Researchers and other experts at museums and in the field of museology came from Mongolia, Myanmar, Thailand, and Japan to share research findings and case studies on the development and maturing of museums, based on their respective historical, social, and cultural backgrounds.

It is my honor and pleasure to have welcomed 15 invited speakers from Mongolia, Myanmar, Thailand, and Japan. In particular I am so delighted that Mr. Ichinkhorloo Lkhagvasuren and Mr. Galbadrakh Enkhbat from Mongolia, Ms. Nu Mra Zan and Ms. Aye Aye Thinn from Myanmar, Ms. Jarunee Incherdchai and Ms. Nitaya Kanokmongkol from Thailand joined us and made presentations. We are also extremely grateful to all speakers and participants of the symposium for sharing ideas and insights, and making productive and successful presentations and discussions over the two days.

This collection of papers presents the results of the above symposium. We hope it will contribute to the development of effective dialogue and networks among museums in the Asian region.

We are extremely grateful to the National Institutes for the Humanities, Japan, for supporting the symposium and to JSPS for supporting the project on which the symposium was based. We offer sincere gratitude and appreciation to JICA and the Lake Biwa Museum for their support and cooperation of long standing in organizing the training courses in museology.

This volume is published with support of the National Museum of Ethnology, Japan (Program for the Promotion of External Publication).

National Museum of Ethnology

Ken'ichi Sudo

Suita, Japan

January 2016 


\section{Contents}

Introduction: Twenty-Year of International Cooperation for Museums and Museology

Naoko Sonoda

\section{Part I Asian Museums Today}

Museums in Myanmar: Brief History and Actual Perspectives

Nu Mra Zan

The Current Status of Mongolia's Museums:

Changes Taking Place in the Practical Activities

of Museums Since the 1990s

Ichinkhorloo Lkhagvasuren

Policies for National Museum

Management: Solutions and Development

Jarunee Incherdchai

Part II Museums in the Info-Age

The Creation of a Registration and Information Database

for Cultural Heritage in Mongolia

Galbadrakh Enkhbat

Rewiring Museum Information: Mobile and Cloud

Atsushi Nobayashi

Managing and Analyzing Museum Environmental Data.

Naoko Sonoda 
Part III Balance Between Conservation and Access for Museums

Exhibition, Conservation, and Documentation at

the National Museum (Nay Pyi Taw)

Aye Aye Thinn

Conservation Science Research at the Museum:

Development of Carbon Dioxide Treatment for Museum Collection

Shingo Hidaka

Part IV Museums and Local Communities

The Situation of Community Museums in the North of Thailand

Nitaya Kanokmongkol

Interactive Museum Activities That Provide Venues

for Innovation: Case Studies from the Lake Biwa Museum

Taisuke Ohtsuka

Museums as Hubs for Disaster Recovery

and Rebuilding Communities

Isao Hayashi

Part V Museums and International Cooperation

JICA's Cooperation in Museum Construction

and Capacity Building of Human Resources.

Shinichi Yoshihara

Museums and Community Development:

With Special Reference to Zambian Cases

Kenji Yoshida

\section{Part VI Afterword}

Twenty-Year of Cooperation

Tsuneyuki Morita 


\title{
Introduction: Twenty-Year of International Cooperation for Museums and Museology
}

\author{
Naoko Sonoda
}

Museology emerged in Europe and North America, leading to museum standards and examples, and producing abundant literature that applies to these areas. In comparison to this, information about Asian museums and museology is still limited in number. This book presents up-to-date information about museums and museology in present-day Asia, focusing on Japan, Mongolia, Myanmar and Thailand.

The peer-reviewed chapters in this volume are written versions of the invited lectures delivered at the international symposium "New Horizons for Asian Museums and Museology" held on 21, 22 February 2015 at the National Museum of Ethnology, Japan (Minpaku). ${ }^{1}$ The symposium was an opportunity to present the outcomes of the Japan Society for the Promotion of Science (JSPS) Core-to-Core Program "New Horizons in Asian Museums and Museology" (FY2012-2014). At the same time, it represented one of the achievements of Minpaku's more than 20-year-long efforts in international cooperation and human resource development for museums and museology.

This proceedings of the symposium provides museum professionals and museology students with chosen examples of museum activities, for example, database construction and sharing information, conservation of and access to museum collections, relationships between museums and local communities, and international cooperation in the field of cultural heritage. Throughout the course of this book, the reader will understand that a museum is not only a place for collecting, representing, and preserving cultural heritage but also plays a fundamental role in community development.

\footnotetext{
${ }^{1}$ The symposium was supported by the Japan Society for the Promotion of Science (JSPS) Coreto-Core Program "New Horizons in Asian Museums and Museology" (FY2012-2014) and by the President's Leadership Fund of the National Institutes for the Humanities, in cooperation with Japan International Cooperation Agency (JICA).

N. Sonoda $(\bowtie)$

National Museum of Ethnology, Senri Expo Park, Suita, Osaka 565-8511, Japan

e-mail: sonoda@idc.minpaku.ac.jp 
In this introductory chapter, the history and outline of 20-year museology training courses at Minpaku are briefly described to help the understanding of the project background. Then, results of studies carried out as a part of the project during FY2012-2014 are summarized, and the objective and contents of the symposium described.

\section{International Human Resource Development in Museology since 1994}

The history of training programs in Minpaku goes back two decades. In the early 1990s, Minpaku was receiving many requests from Asian countries to conduct museum-related training. In 1993, taking advantage of the concurrent visits to Minpaku of researchers of museology from Laos, Myanmar, and Thailand, Minpaku held a short international cooperation seminar on museology. That year became "year zero" for international training in museology at Minpaku.

\subsection{Museology Training Courses}

In FY1994, Japan International Cooperation Agency (JICA) decided to hold a 6-month course called "Museum Management Technology (Collection, Conservation and Exhibition)," in which a then professor of Minpaku, Tsuneyuki Morita played a central role. Minpaku as an institution was commissioned to provide a 2-week "International Cooperation Seminar on Museology" as part of the JICA's course and accepted participants subsequently. Although it was initially begun as a 2-week seminar, a week-long study trip was added later, which was planned and guided by Minpaku. Around ten participants enrolled annually in this JICA course, and always formed a diverse group of individuals in terms of age, experience, position, and responsibility.

Around the tenth year, the course was completely revised. Organizational changes at both JICA and Minpaku also prompted the revision, with JICA transitioning from a special public institution to an independent administrative institution, and Minpaku becoming a member of the Inter-University Research Institute Corporation's National Institute of the Humanities. Upon launching the revised program, Minpaku decided to partner with Lake Biwa Museum known for its pioneering of community-based activities to formulate improved course content. Since then, fully commissioned by JICA, it became the joint responsibility of Minpaku and Lake Biwa Museum to plan, operate, and implement the training course. The name of the course was changed to "JICA Intensive Course on Museology," and it became a three-and-a-half month intensive program. Previously, the course had been geared for a wide range of people - from museum directors to young 
staff - and to meet their different needs, the course had to cover many fields, from museum top management to practical skills for general museum activities. To redress that difficulty, the audience of the reshaped course was focused on people seeking to acquire practical skills.

In FY2009, when the Intensive Course was undergoing another renewal, JICA decided to place a stronger emphasis on defining the desired outcomes of the training. This shift was in response to a movement in Japan to reassess the overall status of the country's international cooperation. To ensure that the training would yield beneficial outcomes in the participants' home countries, JICA decided that, in principle, training would be provided to participants from the same set of countries for 3 years consecutively. Minpaku, however, strongly requested that JICA ensure that their decisions would not exclude countries where demand was high but museum staff was limited in number.

In FY2012, the course title was changed to "Comprehensive Museology Course" and the course was continued for another 3 years. In the new program, the curriculum was revised to enhance content related to museum management, and disaster management.

\subsection{Outline and Features of Museology Courses}

One of the main features of these museology courses has always been a comprehensive approach to covering matters related to museums, rather than focusing on a single topic.

From FY2004 onwards, all courses have been comprised of a 10 week general program (for all participants) and a 3-week specialized program (various electives).

The general program includes an overview of museology, such as collection, conservation, exhibition, collaboration with society, and museum management. The lectures and practice cover these topics, and participants are asked to give presentations resulting from their own experiences and to take part in study trips. The study trips are designed for experiencing the diverse styles and conditions of Japanese museums. In addition to this, during weekends and holidays throughout the course, participants visit museums in the region, according to their own interests and specialties. Usually, they visit a total of 40-50 museums during their stay in Japan. For a 3-week specialized program, three specialized programs are offered each week, from which participants select one. For example, the specialized programs for the 2014 curriculum were; first week, 'Preventive Conservation,' 'Management of a Local History Museum,' or 'Photography,' second week, 'Conservation and Restoration of Objects,' 'Museum and Local Communities,' or 'Filming,' and third week, 'Excavating and Controlling Archaeological Resources,' 'Exhibition Design,' or 'Documentation and Databases.'

Interactive exchange of experiences and information, in other words "forumoriented" learning, instead of unilateral classroom lectures, is what the courses seek to achieve. To that end, participants are given many opportunities to share their 
Table 1 Participants of the museology courses (FY1994-2014) including observers

\begin{tabular}{l|l|l}
\hline & $\begin{array}{l}\text { Number of } \\
\text { participants and } \\
\text { observers }\end{array}$ & Countries and regions \\
\hline Africa & 48 & $\begin{array}{l}\text { 16 (Benin, Botswana, Cameroon, Côte d'Ivoire, Egypt, } \\
\text { Eritrea, Ethiopia, Ghana, Kenya, Madagascar, Mauritania, } \\
\text { Nigeria, Senegal, Swaziland, Tanzania, Zambia) }\end{array}$ \\
\hline Asia & 84 & $\begin{array}{l}\text { 16 (Bhutan, Cambodia, China, Indonesia, Korea, Laos, } \\
\text { Malaysia, Maldives, Mongolia, Myanmar, Nepal, Pakistan, } \\
\text { Singapore, Sri Lanka, Thailand, Viet Nam) }\end{array}$ \\
\hline Europe & 8 & 4 (Armenia, Bulgaria, Finland, Macedonia) \\
\hline $\begin{array}{l}\text { Latin } \\
\text { America }\end{array}$ & 41 & $\begin{array}{l}\text { 10 (Bolivia, Brazil, Chile, Colombia, Costa Rica, Ecuador, } \\
\text { Guatemala, Guyana, Jamaica, Peru) }\end{array}$ \\
\hline $\begin{array}{l}\text { Middle } \\
\text { East }\end{array}$ & 25 & $\begin{array}{l}\text { 6(Iran, Jordan, Palestinian Authority, Saudi Arabia, Syria, } \\
\text { Turkey) }\end{array}$ \\
\hline Oceania & 10 & 4 (Australia, Fiji, Papua New Guinea, Solomon Islands) \\
\hline Total & 216 & 56 countries and regions \\
\hline
\end{tabular}

experiences and ideas through discussion during lectures, museum report presentations, specialty report presentations, a public forum, and final report presentations. In their museum reports, participants are expected to introduce their home museums and discuss the current environment impacting museums in their countries. Having this opportunity at the onset of the course allows other participants and teaching staff to have common understanding of each other's background and of the represented countries. In the specialty reports, participants are asked to report on their specialties and activities at their home museums. The public forum is an opportunity for participants to share the status of their museums with the general public in Japan, and to interact with them. In the final reports, participants attempt to present workable solutions to the challenges they face in their countries. These final reports are prepared utilizing knowledge gained throughout the course, and should help them plan the initial phase of activities at their home museums after their return.

All operations at museums, such as collection, conservation, exhibition, education, social collaboration, public relations, and other services, are interconnected and interdependent. That is why Minpaku and Lake Biwa Museum consider it important for museology to be comprehensive, covering all the main areas of museum activity. The comprehensive nature of the international training courses, over the past 20 years, sets these courses apart from others inside and outside Japan, and is their raison d'etre.

The number of past participants and observers totals 216, from 56 countries and regions (Table 1). Each year, a "Minpaku Co-operation Newsletter" is published, with most content provided by participants in the course that year. This helps to communicate course updates to former participants and represents a growing resource of information for future participants. 


\section{New Developments in International Cooperation}

Many participants of the museology courses are now playing pivotal roles in the operation of museums and in human resource development in their respective countries and regions.

Considering this fact, Minpaku launched in FY2012 a 3-year project, the JSPS Core-to-Core Program "New Horizons in Asian Museums and Museology," as a new initiative of international cooperation though museology. The objective of the JSPS project is to establish a common platform for sharing knowledge and experience, whereby museum specialists and researchers in Asian countries can communicate to each other their activities and research results. The project is carried in collaboration with Mongolia, Myanmar, and Thailand. ${ }^{2}$ The reason for the choice of these three countries was that among the 56 countries and regions that participated to the museology courses to date, these countries all sent participants and observers of around ten in number.

Prior to the international symposium "New Horizons for Asian Museums and Museology" at Minpaku in 2015, joint research meetings for specialists as well as public seminars for students and the general public were organized by Minpaku within the project, in Mongolia (2012), Myanmar (2013), and Thailand (2014).

\subsection{International Workshop on Asian Museums and Museology in Mongolia (2012)}

The first International Workshop on Asian Museums and Museology was held in Mongolia in July 2012. It was composed of three joint research meetings and one public seminar (Sonoda et al. 2014).

A joint research meeting on "Preventive conservation" focused on the problems of museum storage re-organization was held at Kharakhorum Museum in Kharakhorum. A case study from Mongolia was presented by Chogdon Natsagnyam (Kharakhorum Museum, Mongolia). This concerned a UNESCO support project for museums in Mongolia with reference to Erdene Zuu Museum. Within the project, basic and fundamental improvements were made, and museum staff was trained. Erdene Zuu can be considered the ultimate difficult case as it necessitates a balance between the needs of conservation, access to cultural heritage for continuing its activities as a Buddhist monastery, and serving a large number of tourists, as shown

\footnotetext{
${ }^{2}$ Overseas coordinators of the project are: Jarunee Incherdchai from Thailand, one of the 1994 (inauguration year) JICA participants (now Director of the Kanchanaphisek National Museum); Ichinkhorloo Lkhagvasuren from Mongolia, a 1994 observer (now Professor at Mongolian National University of Science and Technology); and Nu Mra Zan from Myanmar, another 1994 observer (now museum consultant to the Myanmar Ministry of Culture). Naoko Sonoda (present author) is from the National Museum of Ethnology, Japan, and has been coordinator for the entire project.
} 
by the presentation of Naigal Tumutbaatar (Erdene Zuu Museum, Mongolia). Present author gave a presentation on an ongoing storage re-organization project at Minpaku, taking as examples the re-organization of two special storage rooms, one for fur/skin/feather and the other for carpets.

Joint research meetings on "Documentation" and "Museum and local community" were held at Mongolian National University of Science and Technology in Ulaanbaatar. Documentation implies sharing information between people from three sides, namely, site people who are the owners of, ethnological researchers who are the developers of, and the third party people who are the users of, the cultural resources, as noted by Masatoshi Kubo (National Museum of Ethnology, Japan). Kubo remarked that this necessitates consideration of different rights regarding sharing cultural resources. An example of nationwide project of registration and documentation for cultural heritage in Mongolia was presented by Dalkhaa Narantuya (Center of Cultural Heritage, Mongolia). To link the museum and local communities, the active involvement of local children and adults in museum activities was required. Public programs carried out at one museum in Mongolia were described by Oyunkhisig Tsanjid (National Museum of Mongolia, Mongolia). Connections with local people were also discussed in detail with the example of the Lake Biwa Museum by Yasushi Kusuoka (Lake Biwa Museum, Japan).

A JSPS Core-to-Core Program Public Seminar on "The Great East Japan Earthquake and the Preservation of Cultural Heritage" was held at Mongolian National University of Science and Technology in Ulaanbaatar. The Great East Japan Earthquake and the subsequent tsunami occurred in March 2011, bringing unprecedented damage in Japan. It affected many tangible and intangible cultural properties. In Mongolia, it might not be necessary to worry about earthquakes and certainly not tsunami. It might not even possible for people in Mongolia to imagine the disaster caused by them. However, other kinds of disaster might occur, such as drought, extreme cold, or fire. This Public Seminar was aimed at sharing information on how disaster may affect both tangible and intangible cultural heritage. The experience of an unprecedented disaster in Japan would surely be helpful for thinking generally about the problems of disaster prevention and response. Rescue activities for tangible and intangible cultural properties were described based on the experiences of researchers at Minpaku: Shingo Hidaka presented work to preserve Japanese folk objects, while Isao Hayashi spoke about the resurrection of local dance traditions; and Kenji Yoshida emphasized the importance of transmitting memories of the disaster to future generations. Tsuneyuki Morita introduced in his closing remarks the notion of failsafe. Failsafe is the concept of a safety zone, used in the worlds of military affairs and IT. It is a place or activity that in the event of a specific type of failure, responds in a way that will cause no harm, or at least a minimum of harm, to other devices or personnel. As a place for the accumulation of human wisdom and survival knowledge, the museum can be thought of as a failsafe for human understanding and heritage.

We hoped that this Public Seminar served an opportunity and starting point to think about disaster prevention in the field of museums and cultural properties in Mongolia. 


\subsection{International Research Meeting on Museology in Myanmar (2013)}

The International Research Meeting on Museology was held in Myanmar in September 2013 (Sonoda et al. 2015a). The Opening Address was kindly read by $\mathrm{Nu}$ Mra Zan (Ministry of Culture, Myanmar) on the behalf of the Union Minister of the Ministry of Culture, and the Closing Speech given by the Vice Minister of the Ministry of Culture. The Meeting was composed of joint research meetings using two venues, one in the North at Bagan Archaeological Museum, the other in the South at the National Museum (Yangon), and these were followed by a JSPS Coreto-Core Program Public Seminar at the National Museum (Yangon).

Some key concepts for museums of our era became evident during these events. A museum today has not only the classic basic functions of collection, conservation, exhibition, and museum education. There are larger potentials as suggested by Tsuneyuki Morita (National Museum of Ethnology, Japan). Kyaw Shin Naung (National Museum (Nay Pyi Taw), Myanmar) observed that an organization is only as good as the individuals it employs, and emphasized the necessity for capacity-building.

The notion of the museum as a forum was frequently mentioned by speakers. The importance of mutual communication and collaboration with exhibition source communities was emphasized with examples of regional museums in Myanmar by Marlar Aung (Lashio Cultural Museum, Myanmar) and ethnographic museums worldwide by Kenji Yoshida (National Museum of Ethnology, Japan). Shigeki Kobayashi (National Museum of Ethnology, Japan) also considered exhibitions as forums. Mie Mie Thet Nwe (National Museum (Yangon), Myanmar) argued for the necessity of school teachers and museums to work together. Masatoshi Kubo (National Museum of Ethnology, Japan) stated that the concept of forum-type collaboration plays an important role also in managing cultural resources. Yoshida underlined in his presentation with reference to an art historian Duncan Cameron's discussion that the museum in our era is required to be a forum where people can encounter the unknown in ways that generate discussion and debate, and is no longer a temple where people come to worship "treasures" with pre-established value.

The concept of forum-type museum leads us to develop relationships and cooperation between the museum and local communities. A good example of the involvement of the local people in museum activities was given taking example of the Lake Biwa Museum, Japan, by Yasushi Kusuoka. Relationships between the museum and local communities is attracting increased interest not only in Japan but in the world of the museum today, as it is directly connected with museum education, lifelong education, and the economic and cultural development of local communities.

Tsyuneyuki Morita (National Museum of Ethnology, Japan) stated that the strong point of a museum lies in the collection of objects. Here, whatever may be said, we come to the consideration that, even for a museum in the twenty-first century, the basic functions of storage and preservation remain and cannot be neglected. This was shown by the presentations of Baby on the conservation of archaeological 
objects at Bagan Archaeological Museum (Myanmar) and Shingo Hidaka (National Museum of Ethnology, Japan) on the rescue operations of objects in emergency situations, and by Aye Aye Thinn on the documentation and conservation of objects at the National Museum (Nay Pyi Taw), Myanmar. Access to collections and realization of the forum-type museum only becomes possible when a museum properly performs its fundamental functions.

\subsection{International Workshop on Asian Museums and Museology in Thailand (2014)}

The International Workshop on Asian Museums and Museology was held in Thailand in August 2014 (Sonoda et al. 2015b). The workshop was supported by the Department of Fine Arts, Ministry of Culture, Thailand. It included a joint research meeting at Kanchanaphisek National Museum, and a JSPS Core-to-Core Program Public Seminar at the National Museum Bangkok.

Through these Workshop presentations, the diversity of museums developed and thriving in Thailand today was introduced. According to Patcharin Sukpramool (Office of National Museums, Thailand) and Jarunee Incherdchai (Kanchanaphisek National Museum, Thailand), more than 77,000 items are arranged and stored by material type at the Kanchanaphisek National Museum and the Central Storage. This Museum and Storage is a good example of visible storage, though the Central Storage is not yet fully open to the public. This initiative deserves special attention as it allows access to collections that would otherwise be out of public view. Access to the collections naturally requires proper collection care and sustainable collection management as stated by the present author's presentation. Collection management refers not only to activities under normal circumstances but also in emergency cases. Sopit Panyakhan (Office of National Museums, Thailand) described the conservation of palm-leaf manuscripts affected both by fire and the water used to extinguish fire. Responses to natural disaster were illustrated by two interventions, one from Nopparat Thepthepha (National Science Museum, Thailand) with the example of severe flood in Thailand, and the other from Shingo Hidaka (National Museum of Ethnology, Japan) with the example of earthquake in Japan, both events occurred in 2011.

Another issue that should be emphasized is the importance of the relationships between museums and people or local communities. Watcharawadee Wichiansri (Songkhla National Museum, Thailand) described community cooperation in a refurbishment project at Songkhla National Museum. Kenji Yoshida (National Museum of Ethnology, Japan) remarked that museums throughout the world are now increasingly assuming the role of a forum in which participants are not only the exhibitor and the audience, but also representatives of the culture exhibited. Museums today are becoming increasingly involved in community-based activities as can be seen at Chiang Mai National Museum (Nitaya Kanokmongkol, Chiang 
Mai National Museum, Thailand) and Lake Biwa Museum (Yasushi Kusuoka, Lake Biwa Museum, Japan). The relations with local communities are capturing increased interest as they can be connected with museum education and lifelong education. Kanokwalee Suriyatham (Roi-Et National Museum, Thailand) introduced the educational programs of Roi-Et National Museum. Museums are also expected to contribute to the economic and cultural development of local communities, as shown by the establishment of Chonburi City Museum (Wised Phetpradab, Fine Arts Department, Prachinburi, Thailand).

We can therefore conclude, with reference to Tsuneyuki Morita (National Museum of Ethnology, Japan)'s keynote speech, that the museum is no longer simply a place to conserve valuable materials, with multiple meanings, for admiration by visitors. We should make more effort to reveal further unknown visual meanings hidden in objects and to establish new methods and technologies to activate them. It is time to reconsider the values and new possibilities of the museum.

\section{The International Symposium "New Horizons for Asian Museums and Museology"}

The international symposium "New Horizons for Asian Museums and Museology", the last in our meeting, was held at Minpaku (Japan) in February 2015.

\subsection{Asian Museums Today}

Three speakers described how their museums are evolving and adapting to their historical, social and cultural environments.

$\mathrm{Nu}$ Mra Zan (Ministry of Culture, Myanmar), in her presentation "Museums in Myanmar: Brief History and Actual Perspectives" retraced the history of Myanmar museums from the earliest such as ancient palaces and Pitaka libraries, through museums established before independence such as Bagan Archaeological Museum, to the most recent-days. Establishment of the Ministry of Culture in 1952, 4 years after regaining independence, led to construction of the first national museum (Yangon) and several other museums. Currently, Myanmar museums supported by the Ministry of Culture can be classified as national museums, archaeological museums, regional cultural museums, and memorial museums. Other kinds of museum are now appearing under other ministries and in the private sector in Myanmar. $\mathrm{Nu}$ Mra Zan pointed out the urgent need for collaboration between these different museums to form a nation-wide museum organization, in order to work together for the improvement of Myanmar museums, and to facilitate international cooperation.

Ichinkhorloo Lkhagvasuren (Mongolian National University of Science and Technology, Mongolia) presented “The Current Status of Mongolia's Museums: Changes Taking Place in the Practical Activities of Museums since the 1990s". 
From the middle of 1920s to the 1990s, the museum affairs of Mongolia were dominated by communist-socialist ideology, demolishing the culture of the exploiter class and creating the culture of the exploited class. The democratic movement since the 1990s brought a big change in the field of culture, particularly for the protection and conservation of historic and cultural heritage, and for the museum activities. It was necessary to improve working conditions in museums, train professional staff, and to participate in international cooperation between museums. New museums were set up as to replace dissolved museums, and other museums were established anew including those under private ownership. Lkhagvasuren remarked that although Mongolia's museums have achieved much in the implementation of their goals, much remains to be accomplished.

Jarunee Incherdchai (Kanchanaphisek National Museum, Thailand) explained the history, role and function of national museums in Thailand in "Policies for National Museum Management: Solutions and Development." There are 41 national museums over the whole country. Since the Act on National Education of 1997, national museums have been expected to provide more educational services and facilities, but a lack of museum personnel and inadequate budgets remain big problems. Recently the decision was made to reduce the number of national museums, and the smallscale national museums, formerly monastery museums, have returned to being monastery museums. To improve the image of national museums, three pilot projects are undergoing: the first project is establishment of seven national museum storage units - a main central storage unit in Pathumthani Province and six regional national museum storage units -; the second project is renovation of the National Museum Bangkok; and the third project is development of the Kanchanaphisek National Museum which will represent all ethnic groups in Thailand.

\subsection{Museums in the Info-Age}

The potential of museums in the twenty-first century, the age of IT, has been explored from diverse angles: nation-wide database construction; sharing of museum information; and computer analysis of the museum environment.

Galbadrakh Enkhbat (Center of Cultural Heritage, Mongolia) gave a detailed account of the "The Creation of a Registration and Information Database for Cultural Heritage in Mongolia." Under the "National Project for Digitization of Cultural Heritage" started in 2005, a total of 42 organizations are involved in the registration and information state database of cultural heritage, using $\mathrm{RCH}$ (Registration of Cultural Heritage) software. So far, 45,645 names and 65,211 movable objects have been registered. For immovable historical and cultural properties, the registration is conducted using RICH (Registration of Immovable Cultural Heritage) software. So far, a total 32,124 historical and cultural immovable properties from 3,100 cultural sites in 15 provinces have been registered. Registration for ICH (Intangible Cultural Heritage) covers 329 soums (sub-provinces) and 9 districts, and 7,206 individuals identified as ICH bearers. In 2014, the "National Project for 
Digitization of Cultural Heritage-2" was approved, aiming to register and document cultural heritage, to take control of conservation and preservation of cultural heritage, to create a digital database for tangible and intangible cultural heritage, and to improve the system used for registration and information database of cultural heritage.

Atsushi Nobayashi (National Museum of Ethnology, Japan) presented "Rewiring Museum Information: Mobile and Cloud". At the National Museum of Ethnology, Japan (Minpaku), ImageFinder was designed to connect different kinds of information on an object through a new digital device: People search information not by using text but images of the objects instead. Another instrument called MAP (Minpaku Anthropological Phototheque) shows pictures taken by Minpaku staff in their fieldwork. These examples show that rapid progress in the design of digital devices and growth of the Internet community have changed the way to offer information on exhibitions and the museum itself. By connecting the information, visitors and users might find additional information or produce new contents and feed them back to the museum. As Minpaku collects materials concerned with human culture, we can show the existence of material culture in each period all over the world. Nobayashi believes that objects and information related to them would be our inheritance of intelligence on this planet.

Present author gave a presentation on "Managing and Analyzing Museum Environmental Data". Two specially customized computer programs have been developed at Minpaku to facilitate the analysis of the museum environment: a pest monitoring data analysis program and a temperature/relative humidity monitoring data analysis program. These analysis programs improve understanding of the museum environment and support efficient and quick discovery of any abnormalities from a preventive conservation point of view. Daily and advanced uses of these data analysis programs were described. For example, a comparative study of the results of temperature and humidity control under the normal regime and under the power-saving regime was carried out based on actual readings, and permitted use of more energy-efficient air-conditioning control since FY2014. For the next development, it is intended to incorporate these analytical programs into "data analysis small packages" that can be used freely by other museums and related institutions.

\subsection{Balance Between Conservation and Access for Museums}

During this session, we discussed two initiatives aimed at balancing the access to and the conservation of museum collections, which is a fundamental need for museums.

Aye Aye Thinn (National Museum (Nay Pyi Taw), Myanmar) presented an initiative of the new national museum in Myanmar in "Exhibition, Conservation and Documentation at the National Museum (Nay Pyi Taw)." The National Museum (Nay Pyi Taw) is under construction and the first phase was scheduled to open in March 2015. The exhibition policy is: to present national prestige and integrity; to 
reveal national cultural heritage to show the soft power and ability of the nation; to build a museum fitting the nation's prestige and grade; and to construct the museum as a good, modern, and attractive one with the right preservation techniques and of a high standard. A total of 9,047 objects have been collected, some excavated from ancient sites and others provided by donation, exchange, or given as awards. Each object arriving at the museum is systematically documented and is being conserved with simple chemicals and ordinary equipment. Aye Aye Thinn recognized the necessity for modern techniques of conservation, documentation, and exhibition.

Shingo Hidaka (National Museum of Ethnology, Japan) reported on "Conservation Science Research at the Museum: Development of Carbon Dioxide Treatment for Museum Collection". He described the development of an enclosure-type insecticidal treatment for ethnographic/folklore artifacts using carbon dioxide. After the successful installation of the system, the technique was applied on a larger scale using a special enclosure-type bag $(11.5 \mathrm{~m}$ in length, $10 \mathrm{~m}$ in width, and $2 \mathrm{~m}$ in height). Since one of the preconditions for development of the system was that the treatment procedures could be performed by museum staff, close attention was paid to worker safety. Other challenges faced were to: minimize the decrease in humidity inside the bag when carbon dioxide is supplied; achieve a uniform distribution of carbon dioxide concentration in a large-scale treatment facility; and establish supplementary methods for killing insects that resist by carbon dioxide treatment (e.g. longicorn beetles).

\subsection{Museums and Local Communities}

To serve local communities, museums today are expected to act as centers for education, local development, and disaster recovery.

Nitaya Kanokmongkol (Chiang Mai National Museum, Thailand) spoke about "The Situation of Community Museums in the North of Thailand". The community museums in the North of Thailand have different patterns: Ethnicity museums and local historical museums. Most ethnicity museums are located in the community of those ethnic people, and present ethnic identity, history, and folklore. Local historical museums are located in historical areas related to the folk life of the communities, and present the history of the areas and the communities. Nitaya considers community museums in Thailand just one type of local museum managed by people, temples, and private units. The situations of the local museums might not be as stable as those of the national museums because the idea of each community unit is different in its understanding of the museum's social function. And nowadays, most local museums are just used as tourist places for the community economy.

Taisuke Ohtsuka (Lake Biwa Museum, Japan), in his presentation "Interactive Museum Activities That Provide Venues for Innovation: Case Studies from the Lake Biwa Museum," considered how to define and construct a better relationship of coexistence between humans and nature through interactive museum activities. The Restoration of Fish Breeding in Paddy Fields project was analyzed as a social 
innovation generated by collaborative and interactive activities in which the museum has been engaged. The museum's researchers contributed no more than the idea and some related knowledge, and other actors such as farmers, prefectural agencies, and researchers in other research institutes organized and advanced the project. Further innovation along these lines is expected to contribute to a "better relationship of coexistence between humans and lakes."

Isao Hayashi (National Museum of Ethnology, Japan) considered "Museums as Hubs for Disaster Recovery and Rebuilding Communities." Among many museums throughout Japan that address the subject of disaster, the attention was drawn to the Chuetsu Earthquake Memorial Corridor which is composed of four facilities and three parks. One facility in Nagaoka acts as gateway to the Corridor, another in Ojiya is responsible for disaster prevention education, the one in Kawaguchi aims to reveal the connections born between people, and the one in Yamakoshi recounts the history, culture, and reconstruction of the village. Memorial parks were established in Myoken as a "park for prayer," in Kogomo as a "park for remembering," and at the Epicenter as a "park for beginnings." The author thus introduced the significance of involving the local people in the planning process and management of facilities that represent and reflect their own experiences.

\subsection{Museums and International Cooperation}

Shinichi Yoshihara (Japan International Cooperation Agency (JICA), Japan) gave a full account of "JICA's Cooperation in Museum Construction and Capacity Building of Human Resources". For many years, JICA assisted developing countries in various fields as the executive agency for Japanese Official Development Assistance (ODA). JICA provides assistance through technical cooperation, loan aid, and grant aid in an integrated manner. The Agency also assists developing countries through dispatch of volunteers, emergency disaster relief, and citizen participatory cooperation. Yoshihara gave examples of assistance to museums in Asia. However, he recognized that, in comparison with other sectors such as infrastructure, health, and education, projects and training for museum development remain small scale.

Kenji Yoshida (National Museum of Ethnology, Japan) gave a presentation on "Museums and Community Development: With Special Reference to Zambian Cases". He emphasized that the museum is not only a storage place for tangible objects of the past, or a destination for tourists, it is also a base for the accumulation and dissemination of local culture, and for creating people's pride in or identity to the community. He argued that only when people have pride in themselves and their own culture, can they challenge and overcome various difficulties. Examples of movements in Africa, especially those in Zambia where he has been working for more than 30 years, clearly demonstrate that the museum, an institution for constructing cultures, can also be appreciated from the viewpoint of community development. He noted that the identity museums to be created should be open-minded 
and those that admit cultural diversity, otherwise it will result only in creating a nationalistic ideology. The networking of museums, both nationally and internationally, is thus essential.

\section{Conclusions}

To a large extent, museums in Japan reached their current state by adapting and modifying what previous museum leaders learned during studies in Europe and/or North America. Developing countries and regions are more or less in the same situation as Japan was and can use Japan's experience. When our international training in museology commenced in 1994, an advantage of getting trained in Japan was the involvement of experts with first-hand experience of the post-war "dawning" of Japanese museums, which was what the participants were experiencing in their homelands. Those people in Japan are now retiring, and the relationship between course participants and Japan is also changing. The result is a shift from a unilateral teaching of experiences to a bilateral sharing of knowledge and experience, in which each party influences the other.

After nearly two decades, many former participants came out to play a central role in the museum activities in their respective countries. Considering this fact, we started a new project in collaboration and organized international meetings and seminars overseas, focusing in Asia. Through the international meetings and seminars held in Mongolia (2012), in Myanmar (2013), and in Thailand (2014), we shared activities, experience, and knowledge about each country's museums. We were especially delighted to learn that, in Mongolia, former participants and observers were working together to hold domestic seminars, suggesting that young experts were being developed. In Myanmar, former participants and observers were teaching a Museology Diploma Course in hope of generating a new workforce, which is a pressing challenge. In Thailand, the diversity of museums encountered - such as one dedicated to visible storage, several kinds of community museums - suggests that the country's museums are gaining momentum.

The meetings and seminars served to strengthen relationships between the project participants' countries in matter of museology, and there was more consequence than that. Museums in remote areas as well as those belonging to other governmental sectors or private section also participated in the meetings and seminars. The meetings and seminars were occasions to connect different museums in the respective countries.

The last of the series, the international symposium "New Horizons for Asian Museums and Museology" was held in Japan (2015) gathering researchers from the above Asian countries. It was conceived as a wrap-up symposium of 3 years collaboration and was aimed to build a framework for sustainable international cooperation which would contribute to the future development of museums. There, the need to continue a museology training course in Japan was strongly requested by all symposium participants, and we learnt that there was a latent demand for more advanced training courses. Museum-based international cooperation indeed 
continues with a new project (JICA Knowledge Co-Creation Program (Group \& Region Focus) "Museums and Community Development") scheduled to be conducted by Minpaku and Lake Biwa Museum in the period FY2015-2017. The new program reflects the present global trend calling for museums to shift their role towards achieving closer relationships with society and users, and promoting collaboration with local communities.

At the same time, importance of academic exchange between museums and/or museum specialists to connect Japan and overseas countries was recognized and emphasized. Actually some former participants came back to Minpaku as visiting researchers and some others are preparing a doctorate in Japanese universities.

New possibilities offered by the current info-age revealed highly promising for further networking and sustainable development for museums. Nowadays, it becomes easy to connect each other, inside and outside the country or region, in order to share information not only between researchers but also connecting the site people and the users in the field of museums, leading to a forum-type and worldwide database sharing.

The symposium, and as a result this volume demonstrate that, Asian countries have, at present, very active and unique museum activities based on their respective historical, cultural and social backgrounds. Each country has developed or is developing its own museology and museums, which is not a simple copy of other countries' museology or museums. Such a tendency is not limited to Asia but can also be seen in other countries, suggesting that Minpaku's 20 year-long effort in international cooperation and training is bearing fruit.

Open Access This chapter is distributed under the terms of the Creative Commons AttributionNonCommercial 4.0 International License (http://creativecommons.org/licenses/by-nc/4.0/), which permits any noncommercial use, duplication, adaptation, distribution and reproduction in any medium or format, as long as you give appropriate credit to the original author(s) and the source, provide a link to the Creative Commons license and indicate if changes were made.

The images or other third party material in this chapter are included in the work's Creative Commons license, unless indicated otherwise in the credit line; if such material is not included in the work's Creative Commons license and the respective action is not permitted by statutory regulation, users will need to obtain permission from the license holder to duplicate, adapt or reproduce the material.

\section{References}

Sonoda, Naoko, Konagaya,Yuki and Lkhagvasuren, Ichinkhorloo, eds. 2014. Ajia ni okeru hakubutsukan, hakubutsukangaku no ima: Mongoru myujiamu kurirutai (Asian Museums and Museology Today - Museum "Quriltai" in Mongolia). Ulanbaatar: Center of Cultural Heritage. (In Japanese and in Mongolian).

Sonoda, Naoko, Tamura, Katsumi, and Nu Mra Zan, eds. 2015. Asian Museums and Museology 2013 - International Research Meeting on Museology in Myanmar- (Senri Ethnological Reports 125). Osaka: National Museum of Ethnology.

Sonoda, Naoko, Hirai, Kyonosuke, and Incherdchai, Jarunee, eds. 2015. Asian Museums and Museology 2014 - International Workshop on Museology in Thailand - (Senri Ethnological Reports 129). Osaka: National Museum of Ethnology. 
Part I

Asian Museums Today 


\title{
Museums in Myanmar: Brief History and Actual Perspectives
}

\author{
Nu Mra Zan
}

\begin{abstract}
The history of Myanmar museums from the earliest such as ancient palaces and Pitaka libraries, through museums established before independence such as Bagan Archaeological Museum, to the most recent-days is described. The establishment of the Ministry of Culture in 1952, 4 years after regaining independence, led to construction of the first National Museum (Yangon) and several other museums. Currently, Myanmar museums under the Ministry of Culture can be classified as national museums, archaeological museums, regional cultural museums, and memorial museums. Other kinds of museum are now appearing under other ministries and in the private sector in Myanmar. There is an urgent need for collaboration between these different museums to form a nation-wide museum organization, in order to work together for the improvement of Myanmar museums, and to facilitate international cooperation.
\end{abstract}

\section{Introduction}

The Cultural Policy of Myanmar aims to raise national prestige and integrity through the preservation and safeguarding of cultural heritage and national character. According to the Cultural Policy, the mission statement of the Ministry of Culture is to "Honor the State with Culture" (Department of Cultural Institute 2000: 8).

Myanmar has an abundant and diverse cultural heritage in both tangible and intangible forms. This heritage is mainly preserved in the National Museum (Yangon) and Bagan Archaeological Museum together with other regional cultural museums and other archaeological museums under the Ministry of Culture.

Museums under the Ministry of Culture can be classified as national museums, archaeological museums, regional cultural museums as ethnological museums, and memorial museums. Not only under the Ministry of Culture but also some religious museums, private museums, and historic houses under other institutions are undertaking the duties and tasks of preserving the cultural heritage of Myanmar.

N.M. Zan $(\bowtie)$

Department of Archaeology and National Museum, Ministry of Culture,

Office No 35, Nay Pyi Taw, Myanmar

e-mail: numra.museum@gmail.com 
Nowadays, other types of museum are appearing more frequently under other ministries and the private sector in Myanmar.

\section{History of Museum Establishment in Myanmar}

\subsection{Earliest Museums}

\subsubsection{Ancient Palaces and Pitaka Libraries}

The ancient palaces of successive periods and Pitaka libraries can be defined as the earliest museums of Myanmar. Arimaddanapura Zeyabon Palace in Bagan, Kamboza Thardi Palace in Bago (Fig. 1), Myanan Sankyaw Palace in Mandalay (Fig. 2), and Shwebonyadanar Palace in Shwebo (Fig. 3) are some examples while Bagan Pitaka Library of King Anawrahta and Chron-Kite Pitaka Library of Mrauk-U are other examples of the earliest museums, which are the only first-generation collection-centered type of museum.

\subsubsection{The First Museum: Phayre Museum}

After the end of the Second Anglo-Burmese War in 1852 came the colonial period in Myanmar, and a museum appeared honoring Sir Arthur Phayre, namely the Phayre Museum, based on the collection of Sir Arthur Phayre, Bago Division commissioner and owner of the collection (Min Naing 1978: 5).

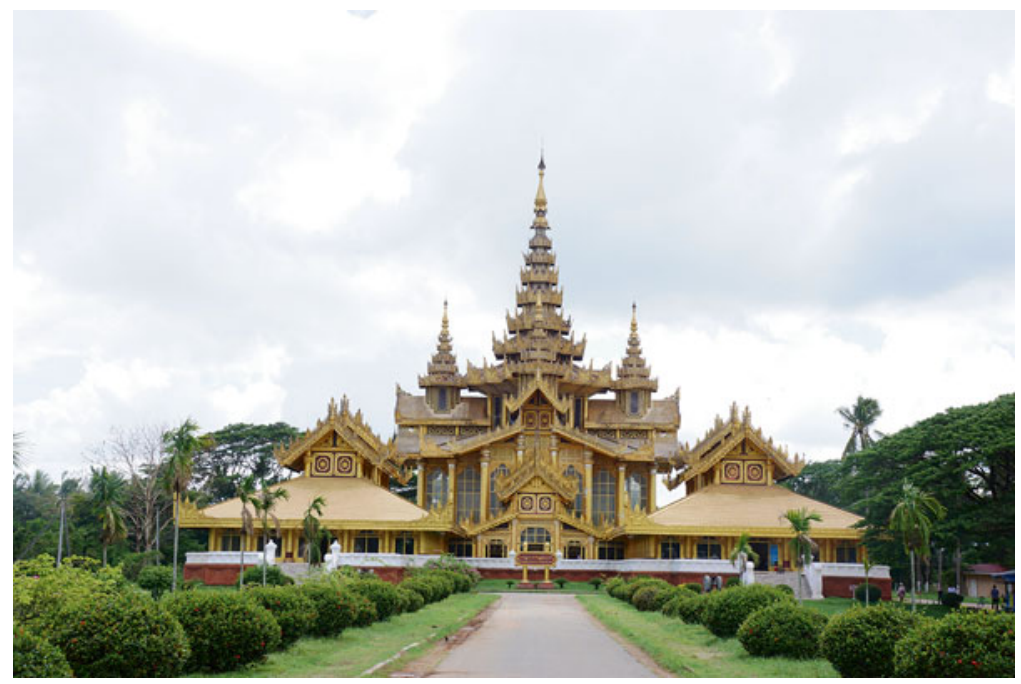

Fig. 1 Kamboza Thardi Palace in Bago 


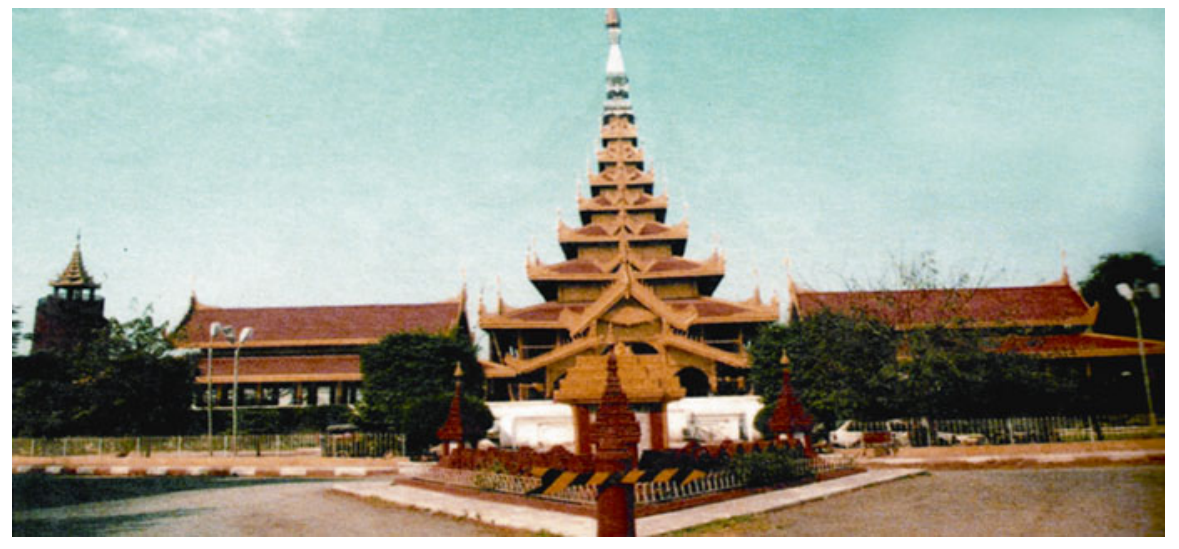

Fig. 2 Myanan Sankyaw Palace in Mandalay

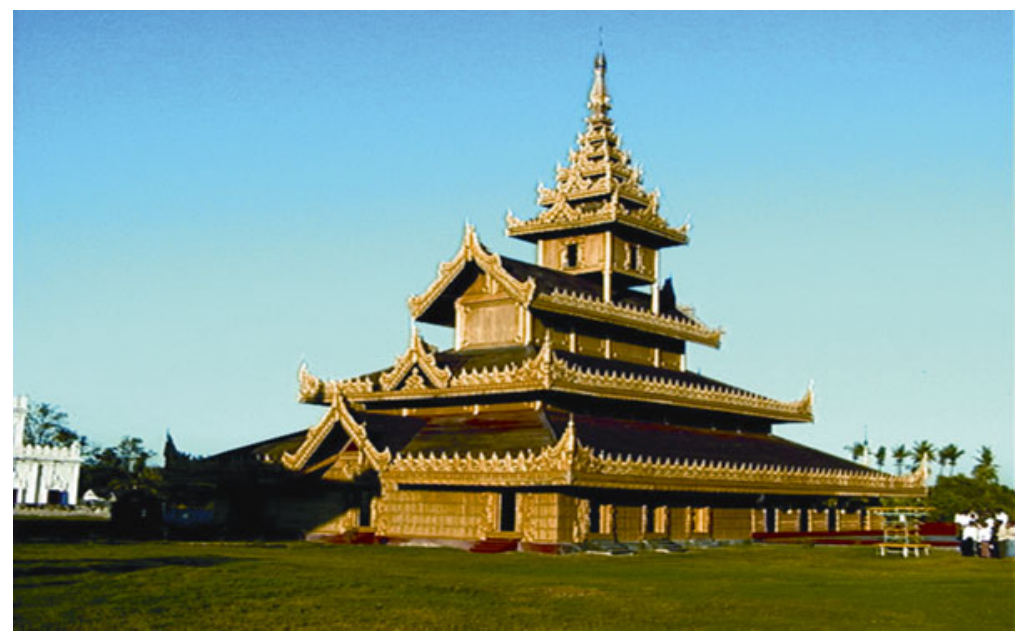

Fig. 3 Shwebonyadanar Palace in Shwebo

The Phayre Museum was built in the gardens of the Rangoon Agri-Horticultural Society in 1871, and it was later dismantled to make way for the Rangoon General Hospital (Taylor 1924:3). After dismantling it, a museum that could be converted into the Phayre Museum in Rangoon (now Yangon) did not appear till 1952 although it can be said that establishment of the Phayre Museum first shaped the Myanmar National Museum. 


\subsection{History of Museums Established in Myanmar Before Independence}

\subsubsection{Brief History of the Bagan Archaeological Museum}

Myanmar was annexed by the British in 1885 and before independence, very few site museums were established. Among them, Bagan Archaeological Museum was the first. The first Bagan Museum (Fig. 4 upper left) was established in 1903 near the famous Ananda Temple and was newly constructed in 1937-38.

After the 1940s, to avoid destruction in the Second World War, all artifacts of Bagan Museum were buried very safely in the earth. When Myanmar regained her independence, the Ministry of Culture, which was established in 1952, arranged to unearth the artifacts and reopened the museum to the public in 1954 (Min Naing 1978: 8, 9).

Museum collections increased year by year and a new octagonal-shaped museum building was built in 1979 (Fig. 4 upper right). As that building also became full of artifacts, the present big four-storied building was established in 1995 and opened to the public on April 17, 1998 (Fig. 4 lower) (Department of Archaeology and National Museum 1997: 2).
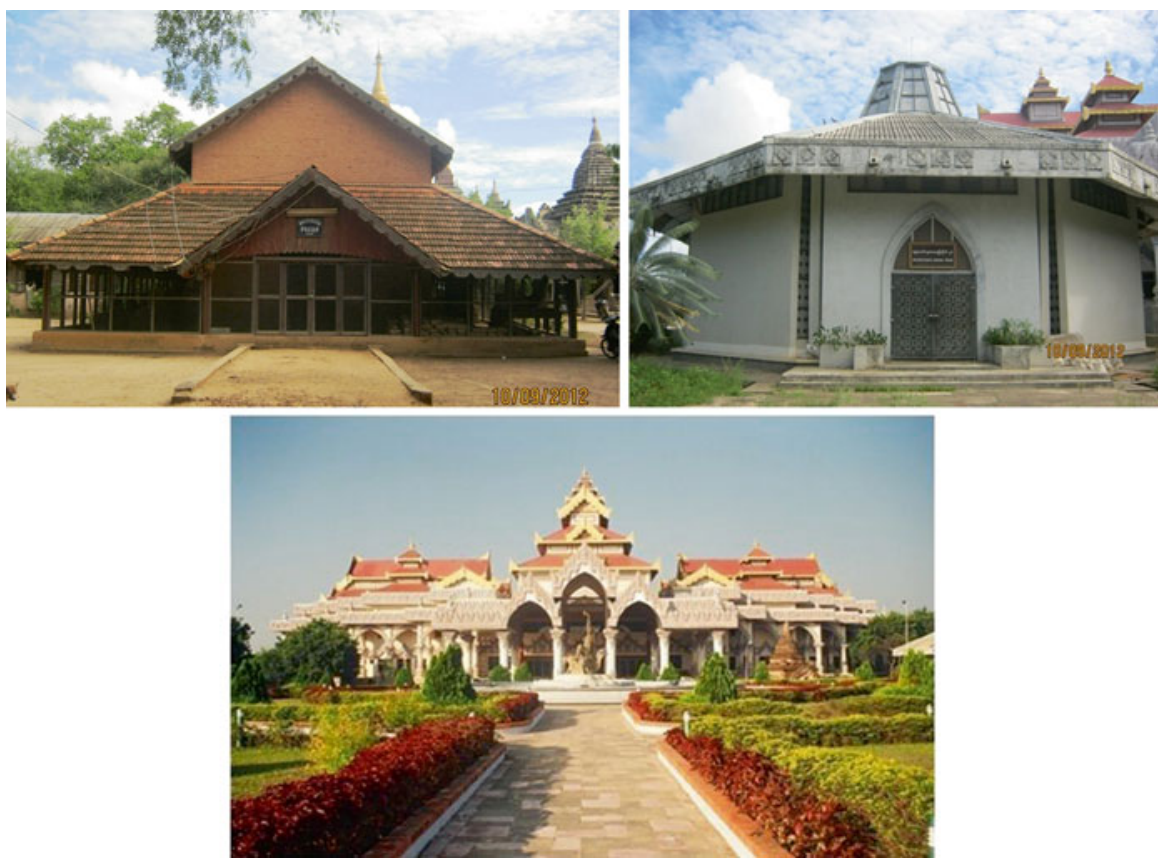

Fig. 4 Bagan Archaeological Museum: The first museum (now storage) (upper left); the second museum (now storage) (upper right); the present museum (lower) 


\subsubsection{Brief History of the Sri Ksetra Archaeological Museum}

One of the most important earliest museums of Myanmar, established in Hmawza Village in Pyay (Prome), was the Sri Ksetra Archaeological Museum. In the 1900s, the Epigraphy Department explored and collected antiquities within the area of Sri Ksetra and, to store them, a small building called Thayet Taw Museum was established near the ancient palace site of Sri Ksetra between 1907 and 1910. After it was burnt down in 1915, Kyaukka Thein was constructed as the first museum of Sri Ksetra in 1915.

The current museum building near Kyaukka Thein Museum and the Monastery Museum was built in 1960-1961 and opened to the public 1 year later (Min Naing 1978: 10).

\subsubsection{Brief History of Other Early Museums}

One of the earliest museums in Myanmar is Mrauk-U Archaeological Museum (Fig. 5) located in Mrauk-U, the last capital of Rakhine Kingdom and now an ancient city of Rakhine State, which was established in 1904. The museum is located just next to the site of the House-of-Jewels on the terrace of the Mrauk-U Palace site (Min Naing 1978: 11).

Another early museum was established in Shwebo in 1904. At first, the Indian government provided subsidies but later it was difficult for it to stand permanently. It has now been substituted by the Shwebonyadana Palace Museum, built in 1994

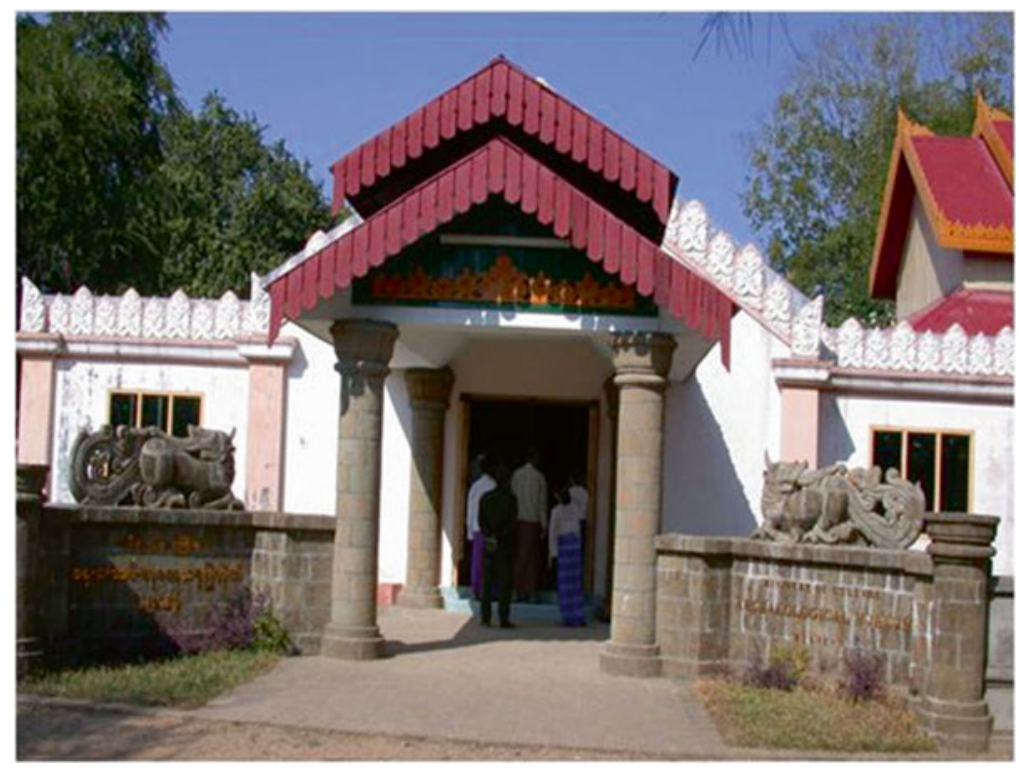

Fig. 5 Mrauk-U Archaeological Museum 
and opened in 1999. Another early museum was located in Mandalay. It was established in 1905 in Mandalay Palace City and called the Mandalay Palace Museum. It is totally different from the present Mandalay Palace Museum, because its collection, comprising objects related to the Palace and various other artifacts, was destroyed by fire because of bombing during the Second World War (Min Naing 1978: 11-13). Today, there is the Myanansankyaw Palace Museum, which was opened to the public in 1996.

Not only were these regional museums opened and governed by the government, but religious museums were also opened by the trustee boards of the pagodas. Among them, the most famous one is the Shwedagon Pagoda Museum whose establishment started from around the 1900s. The present-day Shwedagon Pagoda Museum building was constructed in 1992 (Min Naing 1978: 14).

\subsection{History of Museums Established in Myanmar After Independence}

Four years after regaining independence, the establishment of the Ministry of Culture in Myanmar in 1952 saw the birth of the first national museum in Myanmar (Min Naing 1978: 5).

\subsubsection{Background History of the National Museum (Yangon)}

After regaining independence, the National Museum was opened at the Jubilee Hall Building on the Shwedagon Pagoda Road in June 1952. The collection gradually increased and in 1957, the Royal Lion Throne was moved from the President's Residence to the National Museum and exhibited there. In 1968, it moved to a building in Pansodan Street, which was a former private bank, and it was opened to the public on February 8, 1970 with six exhibition rooms.

Twenty-five years later, the National Museum moved to its present location on 66/74 Pyay Road, Dagon Township in Yangon, and was opened to the public on September 18th, 1996 (Fig. 6).

\subsubsection{Brief History of Regional Cultural Museums in States and Divisions}

According to the policy guideline of the Ministry of Culture, a project to establish regional museums and libraries in some areas of Myanmar was conducted in 1955. After Cultural Councils were organized in respective regions, state or divisional museums appeared in Mandalay for the Mandalay Division (Fig. 7), Kyauk Pyu for the Rakhine (Arakan) Division and Mawlamyaing for the Taninthayi (Tanessarim) Division in 1955. In 1964, these museums were governed by the Ministry of Culture and Rakhine State Museum moved to Sittwe (Akyab), the capital city (Fig. 8). 


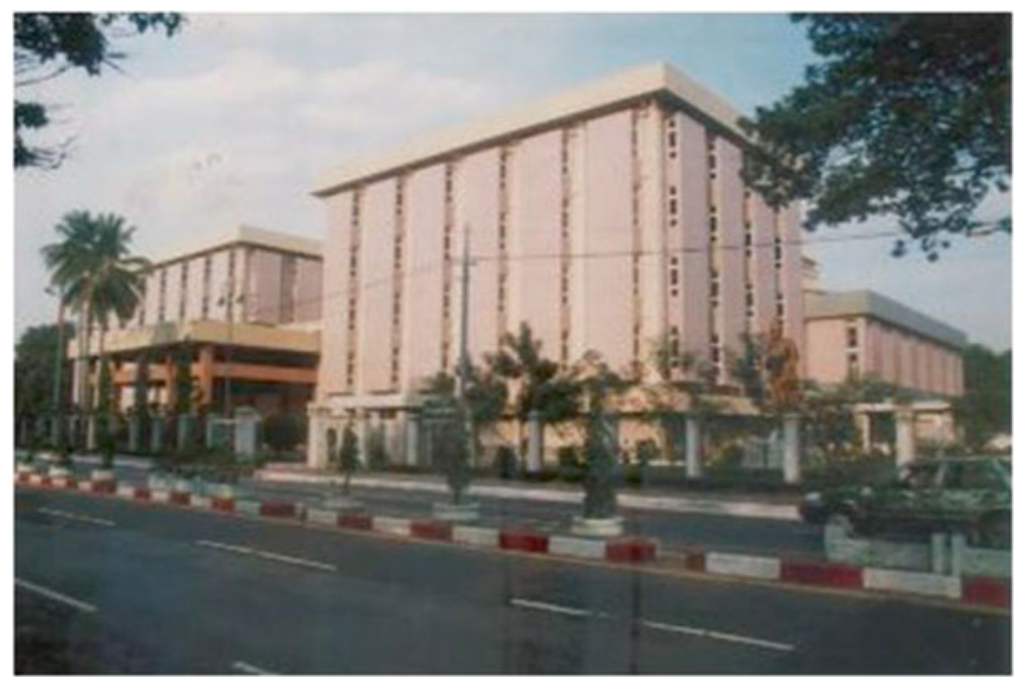

Fig. 6 National Museum (Yangon)

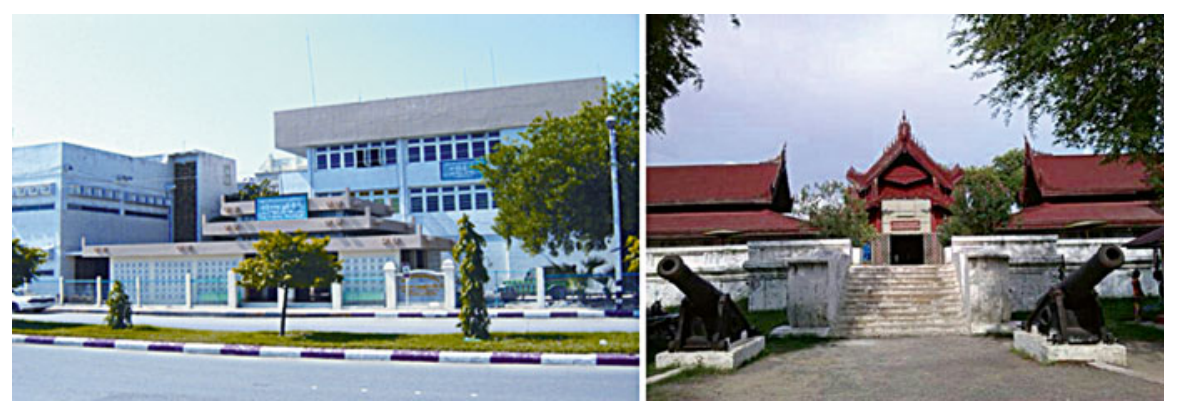

Fig. 7 Regional cultural museums in Mandalay: Mandalay Cultural Museum (left); Mandalay Palace Cultural Museum (right)

Mawlamyaing Cultural Museum (Fig. 9) became the regional museum of Mon State in 1974 (Min Naing 1978: 16).

In the Ayarwaddy Division, the history of the Pathein Cultural Museum (Fig. 10) is different from other regional museums. It started as the Bogyoke Aung San Library in 1960 and 3 years after its establishment, it was handed over to the government and became the Ayarwaddy Division Museum and Library (Min Naing 1978: 17).

Bogyoke Aung San Museum (Fig. 11), where General Aung San lived with his family from 1945 to 1949 till he was assassinated, was opened to the public in 1963. Bogyoke Aung San Residence Museum, where he was born and lived with his parents till he passed matriculation in Nat Mauk, also became a memorial museum in 1972 (Min Naing 1978: 20). 


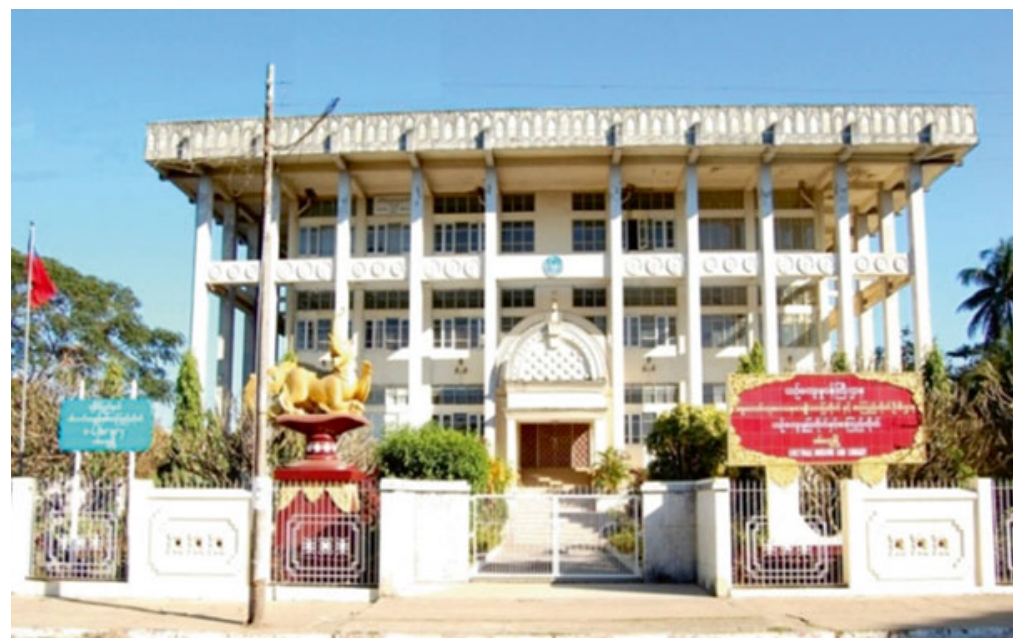

Fig. 8 Sittwe Cultural Museum

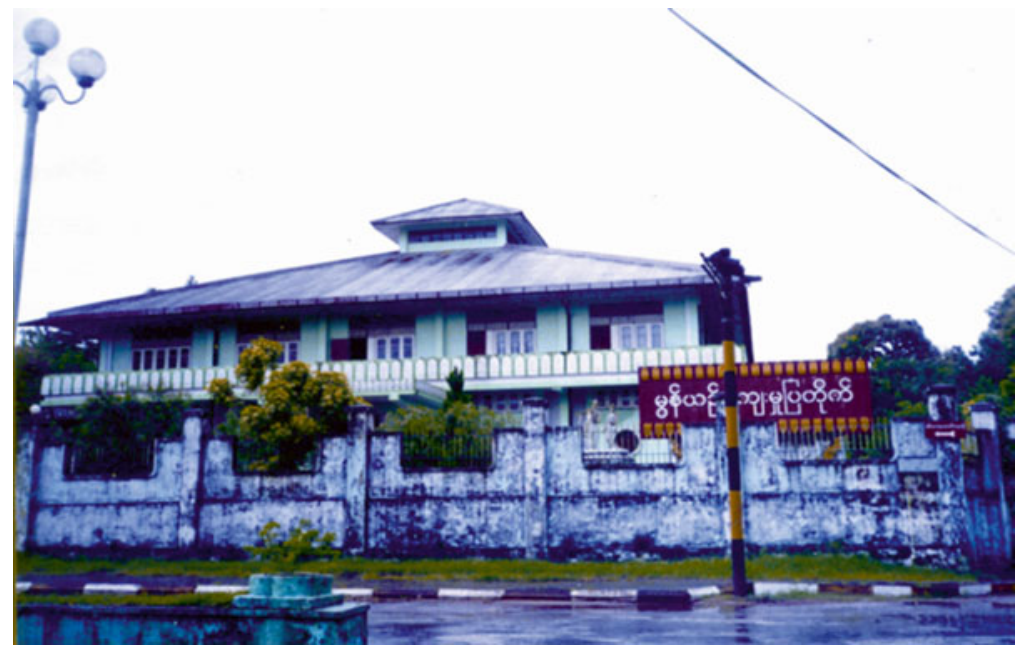

Fig. 9 Mawlamyaing Cultural Museum

Kachin State Cultural Museum (Fig. 12) in 1963 in Myitkyina, Kayah State Cultural Museum (Fig. 13) in 1967 in Loikaw, Kayin State Cultural Museum (Fig. 14) in 1955 in Hpa-an, Shan State Cultural Museum (Fig. 15) in 1956 in Taung Gyi, and Chin Special Divisional Museum (Fig. 16) in 1963 in Haka were established by their respective state governing bodies and handed over to the Ministry of Culture in 1972, and became government-run regional level cultural museums (Min Naing 1978: 17, 18). 


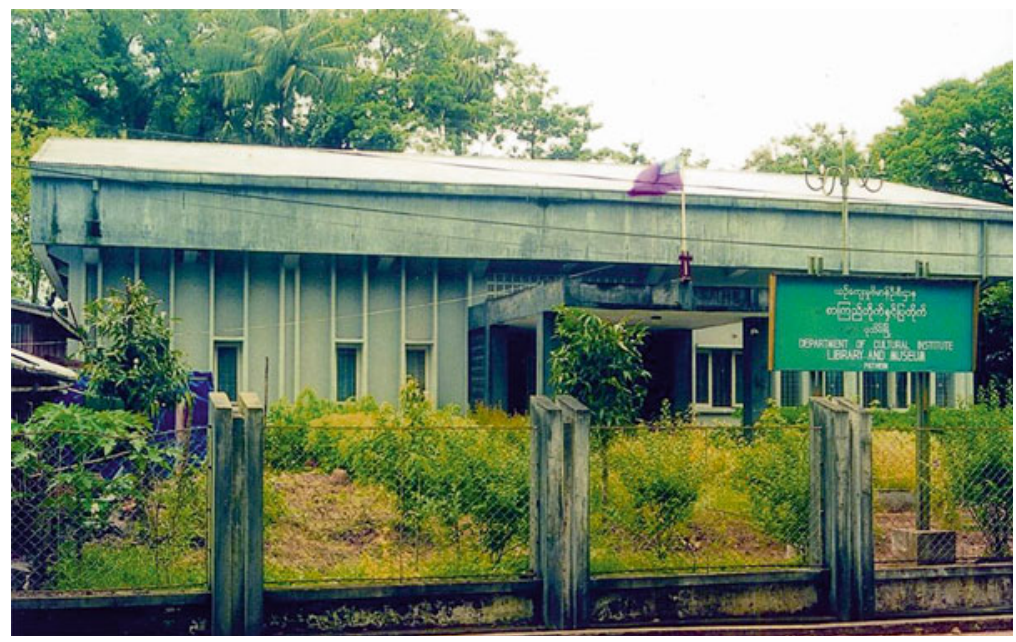

Fig. 10 Pathein Cultural Museum

Now, all of their buildings have been newly constructed in large compounds during the military government's time. Most of the regional cultural museums acquired ethnic materials together with some archaeological finds, found in their regions.

Memorial museums have collections that are different from those of regional cultural museums; they house the belongings of the person remembered, for instance, the clothing, furniture, books, utensils, and documents of General Aung San and U Thant. At present, U Thant's House Museum is also established by a private sector in Yangon.

\subsubsection{Brief History of Archaeological Museums}

Three ancient cities, namely, Sri Ksetra, Beikthano, and Halin are now in the World Heritage List. Among them, Sri Ksetra Museum (Fig. 17) is the one of earliest museums, established in the 1900s before independence.

Beikthano Archaeological Museum (Fig. 18) was established in 2008 and opened to the public in September 2009. It was built on a grand scale with the characteristics of Beikthano Pyu.

Halin Archaeological Museum was established in 2012 and opened in January 2013 as the last established archaeological museum by the Ministry of Culture to date.

There is not only Sri Ksetra, Beikthano, and Halin, but also other new site museums such as Tagaung Archaeologcial Museum (Fig. 19) (Department of Archaeology and National Museum 2014: 2). 
Fig. 11 Bogyoke Aung San Museum (Yangon)

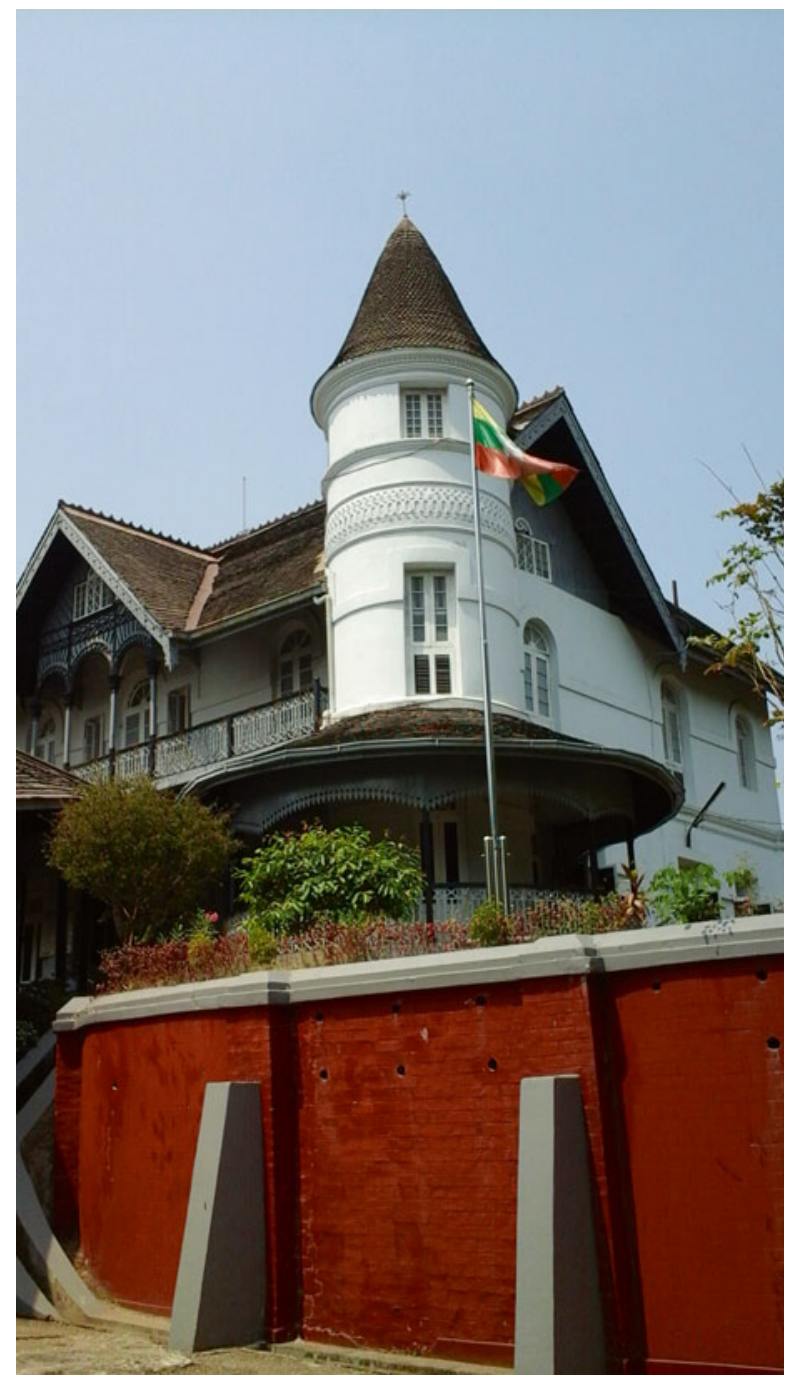

\subsubsection{Brief History of the National Museum (Nay Pyi Taw)}

After moving the capital city from Yangon to Nay Pyi Taw in 2006, the government decided to establish a new national museum in Nay Pyi Taw. The construction works started in 2011 and it is now nearly finished (Fig. 20). Display work has now started and the museum is intended to open to the public phase by phase at the end of fiscal year 2014-2015 (Department of Archaeology and National Museum 2014: 4). 


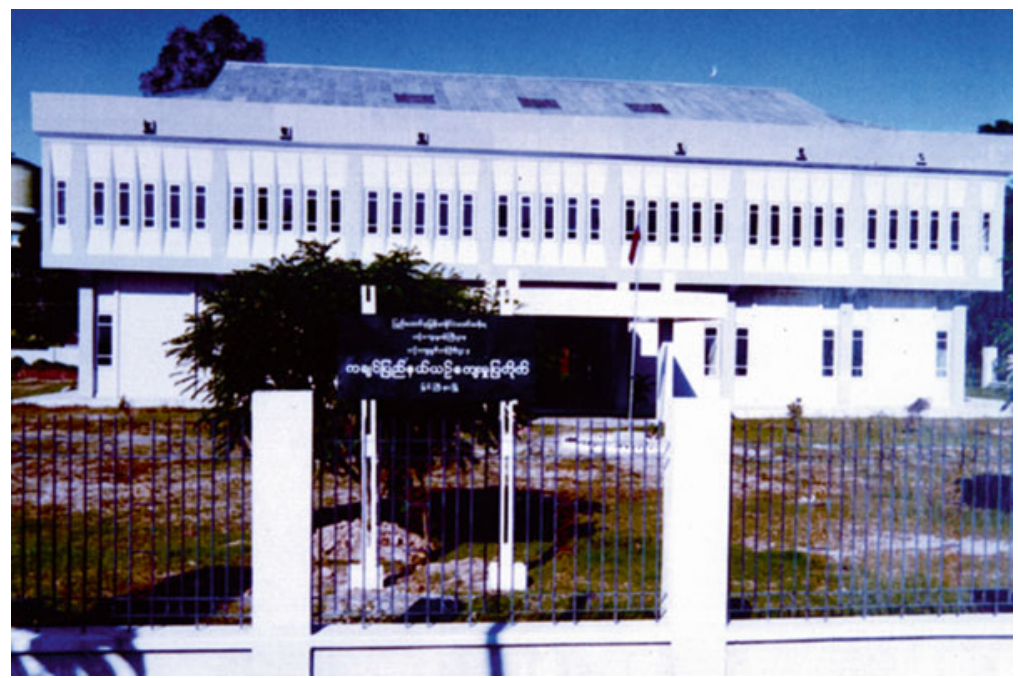

Fig. 12 Kachin State Cultural Museum

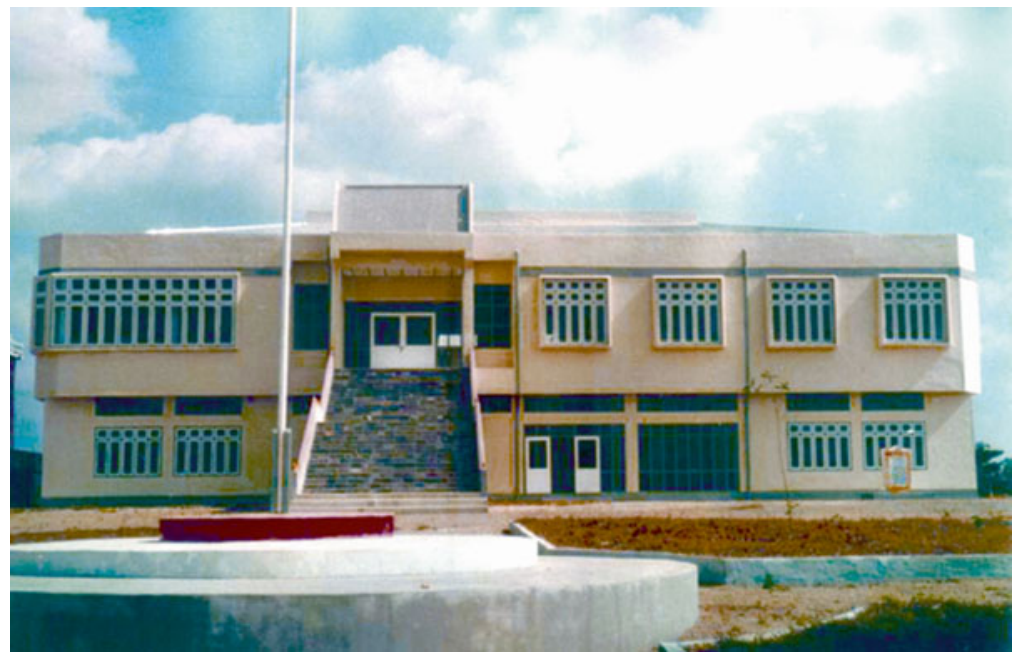

Fig. 13 Kayah State Cultural Museum

\section{Actual Perspectives on Myanmar Museums}

\subsection{Actual Perspectives on the National Museums of Yangon and Nay Pyi Taw}

In fact, the situation at the beginning of the National Museum (Yangon) can be identified from a report of Dr. Nihar-ranjanan Ray as "a poor nucleus of such a museum exists in the Jubilee Hall at the present moment, consisting of a small 


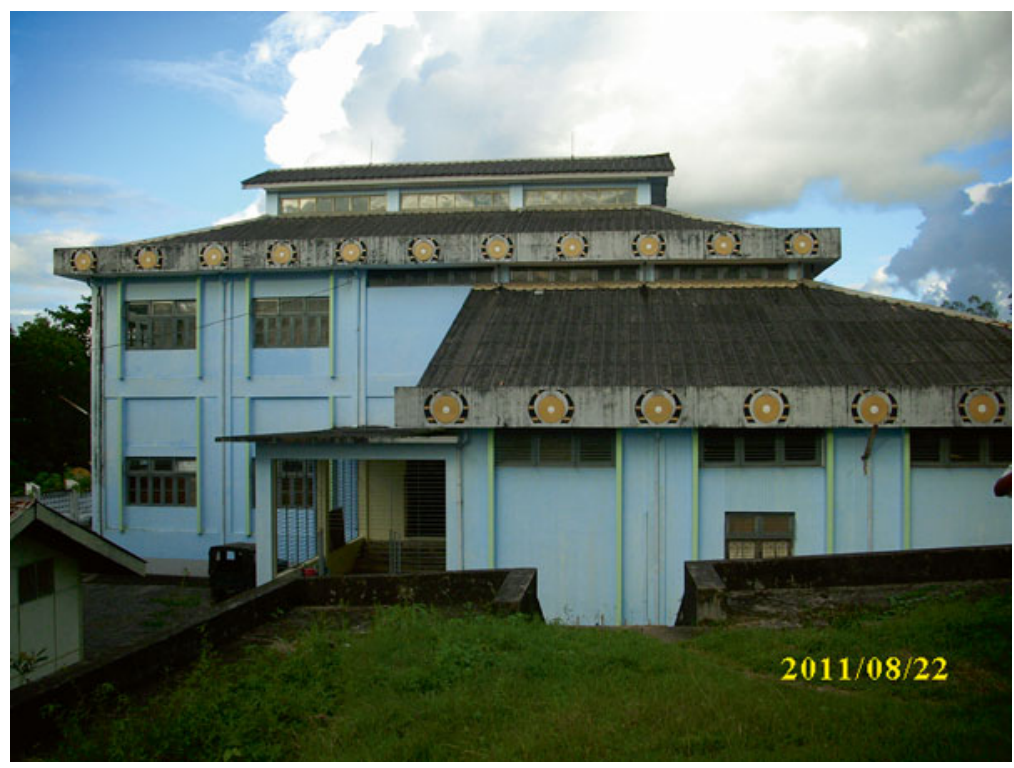

Fig. 14 Kayin State Cultural Museum

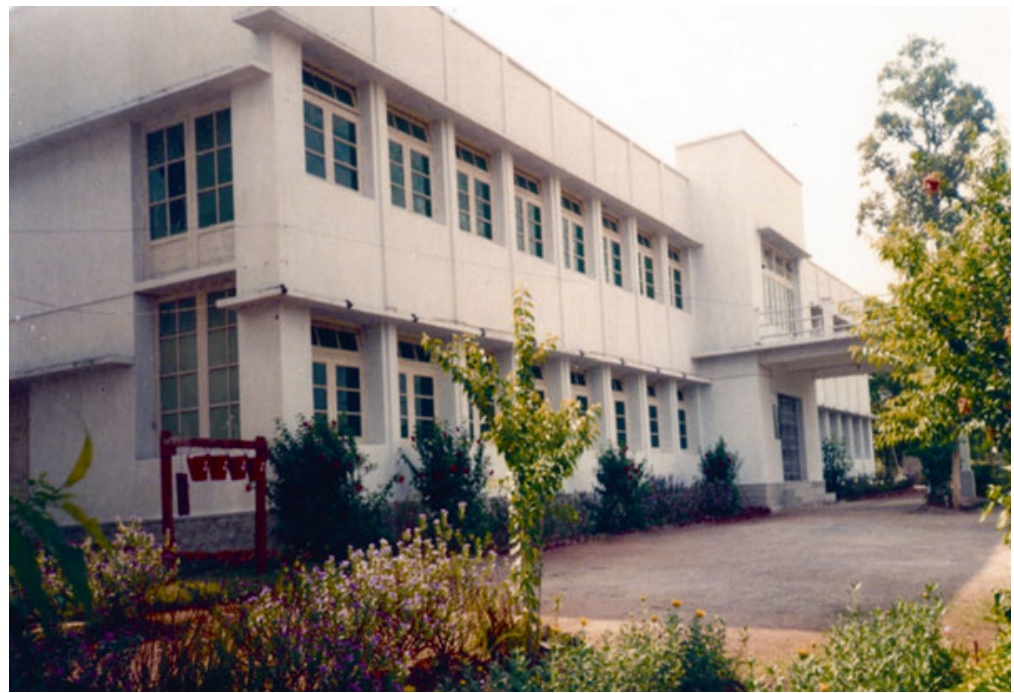

Fig. 15 Shan State Cultural Museum 


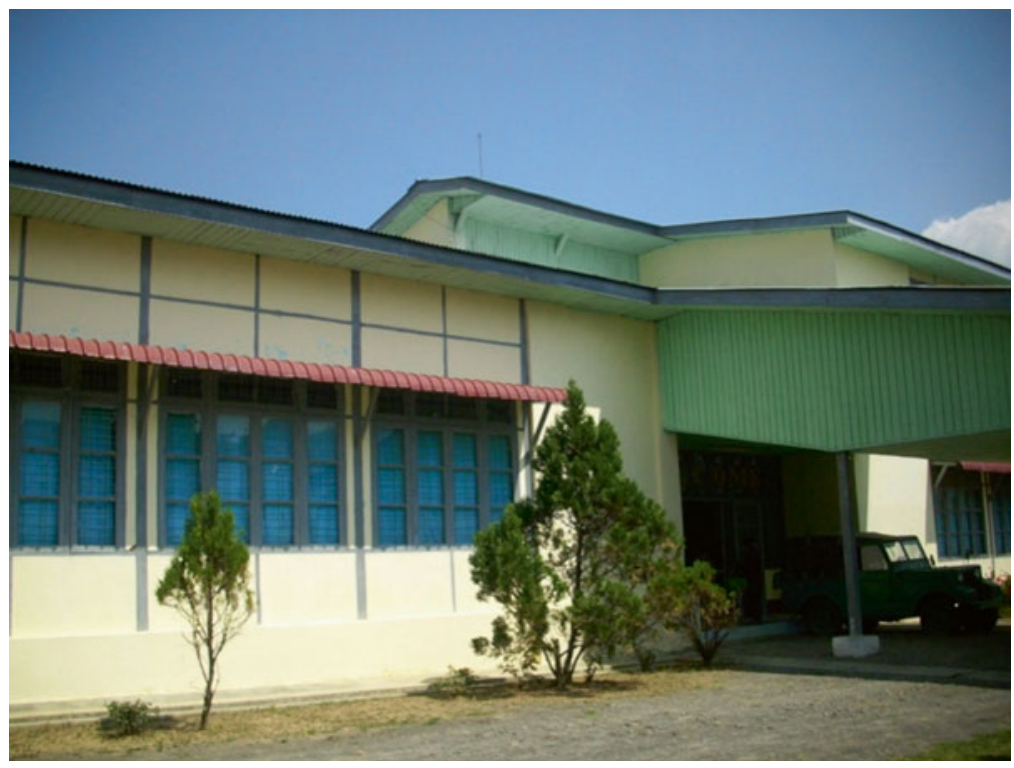

Fig. 16 Chin State Cultural Museum

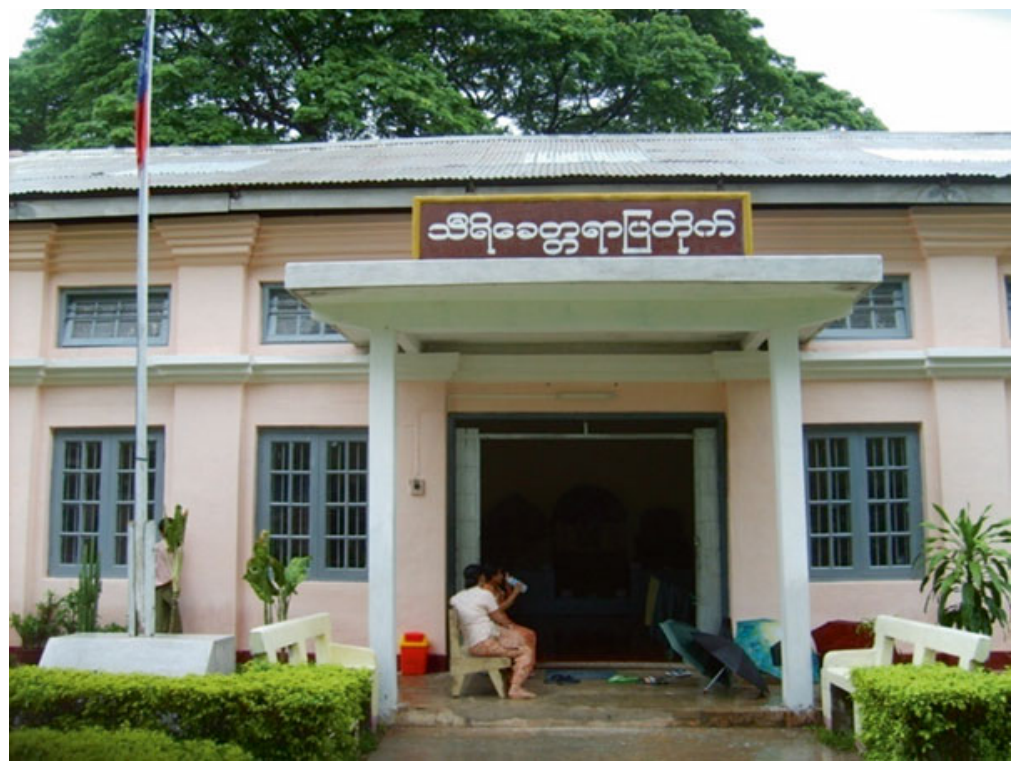

Fig. 17 Sri Ksetra Museum 


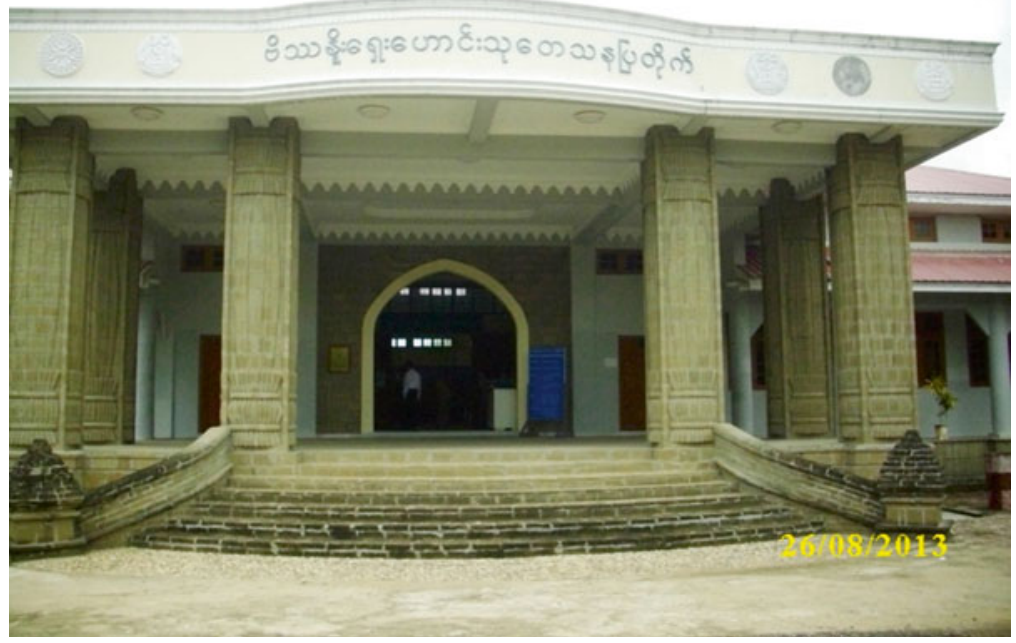

Fig. 18 Beikthano Archaeological Museum

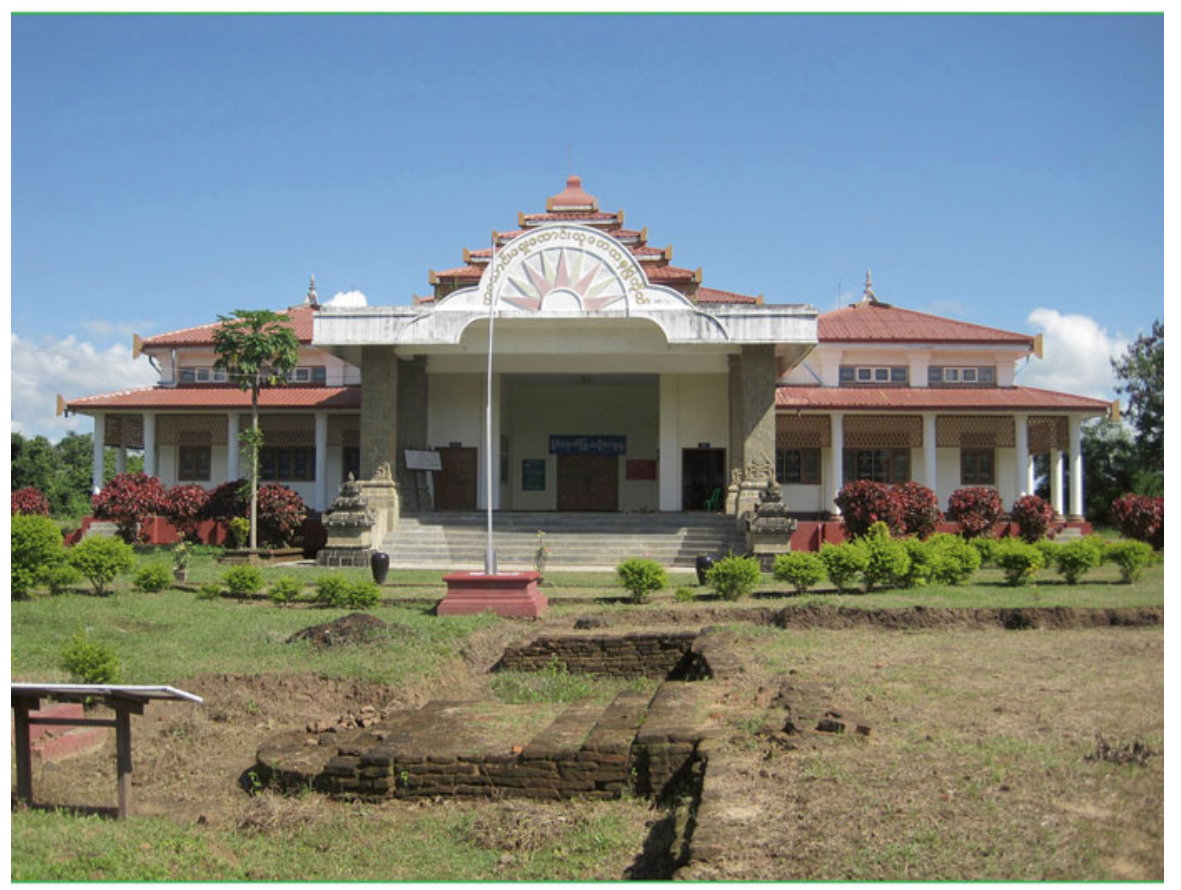

Fig. 19 Tagaung Archaeological Museum 


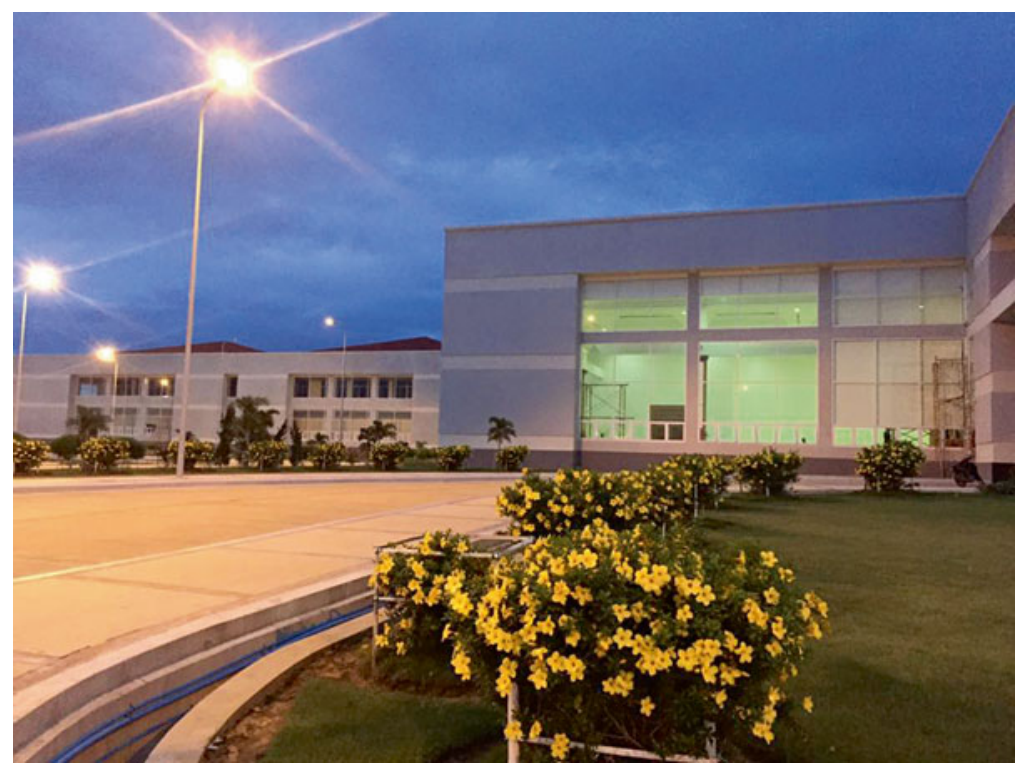

Fig. 20 National Museum (Nay Pyi Taw)

collection of objects of arts and crafts and of ethnology and archaeology. But attempts are being made to acquire representative objects of real value and a good sum has been budgeted for the current year, for the purpose." However, ancient palm leaf manuscripts and paper parchments, royal epistles and seals, musical instruments, ancient coins, royal costumes, royal furniture, ethnological items, and Myanmar traditional handicrafts were on display in different sections.

From that situation, the collections increased gradually and over 3,840 items were collected and exhibited from 1952 to 1962, one decade. In 1957, the Royal Lion Throne was moved from the President's Residence to the National Museum and exhibited there. Since 1962, the National Museum changed into a type of historical museum and exhibitions of the twentieth-century history of Myanmar and related exhibits were highlighted. In 1968, after moving to a building in Pansodan Street, the historical museum changed its type again to a national museum. In 1969, one exhibition room for culture of nationalities was extended. At that time, there were only six exhibition rooms, i.e., Royal Lion Throne and Royal Regalia, Stone Age, Pyu Period, Bagan Period, Arts and Crafts, and Performing Arts (Department of Archaeology and National Museum 1996: 4). There was also an art gallery, with the aim of establishing a new and separate national art gallery. The National Museum's collection is mostly based on donations by local people and transfers from archaeological departments.

According to this background history, the National Museum (Yangon)'s display is a combination of the themes of history, archaeology, art, and ethnology. However, because of the inappropriate architecture, historical exhibition rooms are out of sequence. Moreover, due to the lack of location space, storage areas and conservation 
areas, which are highly important, are very limited and difficult to extend. Mismanagement by the ministerial authorities has also made the National Museum smaller than before by placing other departmental branches in the same building.

But, we can conclude that "something is better than nothing," because after 25 years, the National Museum was able to move to its present place, with some space for landscaping and car parking, the likes of which it has never owned before, although the area is becoming smaller as the number of visitors is increasing. And we would also like to thank our government for having the chance to change the displays of the exhibition rooms by providing budget. We have started to implement the reform project since the 2013-2014 budget year, and the reception hall, ticket counter, and Myanmar Epigraphy and Calligraphy exhibition room are completely finished. In 2014-2015, this budget year, the Myanmar Art Gallery is nearly finished and the Myanmar Historic Period exhibition room has even changed title to "Myanmar Civilization" by adding Pyu period objects from the Myanmar Protohistoric Period exhibition room. The Myanmar Civilization exhibition room is now divided by partitions from the Myanmar Regalia exhibition room and new installation works are being undertaken.

Successful work has been rental of the audio guide system in four languages, Myanmar, English, Japanese, and Chinese, for visitors. A Japanese company (Miyashita Co. Ltd.) donated 42 sets of the audio guide system to the National Museum (Yangon).

The appearance of one new national museum in Nay Pyi Taw has been commented on by some outsiders and foreigners but it should be welcomed as a highstandard national-level museum in Myanmar. It is also now at a serious stage trying to open at least six exhibition rooms at the end of this budget year.

However, we need to change the organizational strength of both national-level museums. Another weakness is that the volunteer system cannot be practiced here like in foreign countries. All strength is mostly full-time staff, and only very few persons like cleaners and garden workers are part-time staff. The major constraint is a lack of technicians in museum function areas like exhibition and conservation. They have basic knowledge on museology through the Diploma in Museology courses and foreign short courses on general museology but are not experts in specialist areas. So, the staff needs more long-term training on particular museography subjects from developed countries.

Although the National Museum (Yangon) can stand as the leading museum in museology in Myanmar, our training courses are mostly based on theory. Because of a lack of facilities and budget constraints, Diploma in Museology classes cannot provide practical and experimental work on museography, especially in the area of conservation.

Another weak point is we cannot form any national organization on the museum community. The weakest point is we are still not a member of ICOM. 


\subsection{Actual Perspectives on Archaeological Museums, Regional Cultural Museums, and Other Types of Museum}

At the present time, almost all of the museums under the Ministry of Culture are changing their displays gradually one by one. For example, Mon State Cultural Museum (Mawlamyaing), Kayin State Cultural Museum (Hpa-an), Ayawaddy Region Cultural Museum (Pathein), Pakhangyi Archaeological Museum, Sri Ksetra Archaeological Museum, and Beikthnoe Archaeological Museum have reformed their displays within the last 5 years. At the same time, some new museums appeared such as the Halin Archaeological Museum and Northern Shan State Cultural Museum (Lashio).

Among other types of museum, many religious museums of pagoda trustees want to change their displays with the technical assistance of museum experts from the Ministry of Culture. Shwedagon Pagoda Museum in Yangon and Mahamuni Museum in Mandalay are good examples.

I am trying to help them not only with the display areas, but also with systematic documentation and staffing. However, the trustee board members began willingly to cooperate with the museum experts. This is one of the achievements. In Nay Pyi Taw, the new Upartasanti (the replica pagoda of Shwedagon Ceti) museum was established since 2010.

At the moment, the new Military Museum, Gems Museum, Planetarium, Railway Museum, the small Aquarium, National Landmark Garden, and Safari Park are open to the public in Nay Pyi Taw. In Pyin Oo Lwin, the Fossil Museum and the Butterfly Museum are being extended by the private sector. In Yangon, private museums will soon appear.

The most important weak point is the need for strong museum law and regulations on how to establish a new museum. We would welcome many new museums appearing with momentum. It shows that Myanmar local people have begun to take an interest in museums.

\section{Conclusion}

The museums not only under the Ministry of Culture, but also from other ministries and other institutions including the private sector, need to collaborate to organize one national museum organization to work together for the improvement of the Myanmar museum world. Moreover, developed nations' support and aid are welcome for Myanmar museum development. 
Open Access This chapter is distributed under the terms of the Creative Commons AttributionNonCommercial 4.0 International License (http://creativecommons.org/licenses/by-nc/4.0/), which permits any noncommercial use, duplication, adaptation, distribution and reproduction in any medium or format, as long as you give appropriate credit to the original author(s) and the source, provide a link to the Creative Commons license and indicate if changes were made.

The images or other third party material in this chapter are included in the work's Creative Commons license, unless indicated otherwise in the credit line; if such material is not included in the work's Creative Commons license and the respective action is not permitted by statutory regulation, users will need to obtain permission from the license holder to duplicate, adapt or reproduce the material.

\section{References}

Department of Archaeology and National Museum. 1996. Guide to the National Museum (Yangon). Yangon: Ministry of Culture. (In Burmese).

Department of Archaeology and National Museum. 1997. Guide to Bagan Archaeological Museum. Yangon: Ministry of Culture. (In Burmese).

Department of Archaeology and National Museum. 2014. Annual Report of the Department of Archaeology and National Museum 2013-2014. Yangon: Ministry of Culture. (In Burmese).

Department of Cultural Institute. 2000. Facts and figures on the Department of Cultural Institutes. Yangon: Ministry of Culture. (In Burmese).

Min Naing U. 1978. Guide to Myanmar museums. Yangon: Ministry of Culture. (In Burmese).

Taylor, L.F. 1924. A Burma Provincial Museum. Journal of the Burma Research Society 14(Part I): $1-12$. 


\title{
The Current Status of Mongolia's Museums: Changes Taking Place in the Practical Activities of Museums Since the 1990s
}

\author{
Ichinkhorloo Lkhagvasuren
}

\begin{abstract}
From the middle of 1920s to the 1990s, the museum affairs of Mongolia were dominated by communist-socialist ideology, demolishing the culture of the exploiter class and creating the culture of the exploited class. The democratic movement since the 1990s brought a big change in the field of culture, particularly for the protection and conservation of historic and cultural heritage, and for the museum activities. It was necessary to improve working conditions in museums, train professional staff, and to participate in international cooperation between museums. New museums were set up as to replace dissolved museums, and other museums were established anew including those under private ownership. Mongolia's museums have achieved much in the implementation of their goals, but much remains to be accomplished.
\end{abstract}

\section{Particulars of Museum Activities in Mongolia Prior to the Period of the Democratic Movement}

With the victory of the People's Revolution in 1921, a new period of development started in the political and social spheres of Mongolia. In November of 1921, the People's Government issued a resolution to start preparations for the establishment of a museum within the structure of the Institute of Sutras and Scripts (currently, the Academy of Sciences). The Institute of Sutras and Scripts immediately started implementing this important decision of the Government of Mongolia. First of all, the Institute of Sutras and Scripts issued an official request to the chanceries of aimags (khanates) and khoshuuns (banners), by which they ordered the sending to the institute of information relating to historic and cultural artefacts and interesting things that was available or known in their local areas and territories. In addition, researchers from the Institute of Sutras and Scripts started working in rural areas

\footnotetext{
I. Lkhagvasuren $(\bowtie)$

Mongolian National University of Science and Technology,

Baga Toiruu -34, SHUTIS building -2, Ulaanbaatar 210646, Mongolia

e-mail: suren_san@yahoo.com 
and local territories to collect exhibits for the museum. This way, collection of museum exhibits started in Mongolia. As a result of intensive work conducted by the Institute of Sutras and Scripts in the collection of older books and sutras in the rural countryside, 2100 books in foreign languages, 600 older books and sutras in the Mongolian language, 250 books and sutras in the Tibetan language, and about 1400 books and sutras in the Japanese and Manchu languages were collected (Sereeter et al. 2003: 30). In 1924, the People's Government approved the "Rules for the Protection and Conservation of Antiques." This document was the first legal act for the protection and conservation of historic and cultural artefacts, and for the conducting of museum activities. Upon the approval of this legal act, many achievements have been made in respect of finding items with museum significance, registering those items at an archive of the museum, documenting and organizing preservation and conservation activities, and conducting researches of and putting items of the museum into scientific circulation. However, the Institute of Sutras and Scripts that was set up anew at that time encountered a number of challenges including lack of experience managing museum works, limited possibilities regarding registration and documentation of museum artefacts and pieces, lack of museum buildings that were specially fit for preservation and conservation of museum items, and lack of professional employees.

To overcome the above obstacles, the signing of an agreement between the Institute of Sutras and Scripts and the Russian Academy of Sciences was an event of important significance. With this agreement starting 1923, it became possible to work in Mongolia for the Mongolia and Tibetan Research Unit organized by the Russian Academy of Sciences. This research group was led by a noted Mongolia studies scholar and among the participants were A. D. Simukov and V. I. Lisovskii who later became renowned scholars of Mongol studies (Konagaya et al. 2007: 51). The research unit while working in Mongolia for over a period of 3 years actively participated in the preparations for setting up a first museum in Mongolia, collecting museum artefacts, registering and documenting museum items, organizing preservation and conservation, and providing museum employees with practice and experience of museum works (Konagaya et al. 2008: 89). The research group led by P.K. Kozlov conducted an archeological excavation at Noyon Uuul (150 km northeast of Ulaanbaatar) and found a number of interesting findings relating to economics, as well as artefacts with material and cultural significance of the early Khunnus. The archaeological excavation at Noyon Uul and the findings there created a real sensation among the world scientific community at that time. A temporary exhibition, with findings of this archeological excavation at that time, was like a new page in the cultural life of Mongolia. Currently, most of the findings are kept in the storage facility of the State Hermitage in Saint Petersburg of the Russian Federation. A few of them are kept at the National Museum of Mongolia. Around the time when the P.K. Kozlov led research group worked in Mongolia in May 1925, a cooperation agreement was signed between the Institute of Sutras and Scripts and the American Museum of Natural History. With the signing of this agreement, it became possible for the third Asian expedition led by Roy Chapman Andrews, American scholar and Central Asian student, to work in southern Gobi. 
Fig. 1 O. Jamiyan,

Chairman of the Institute of Sutras and Scripts and of the museum

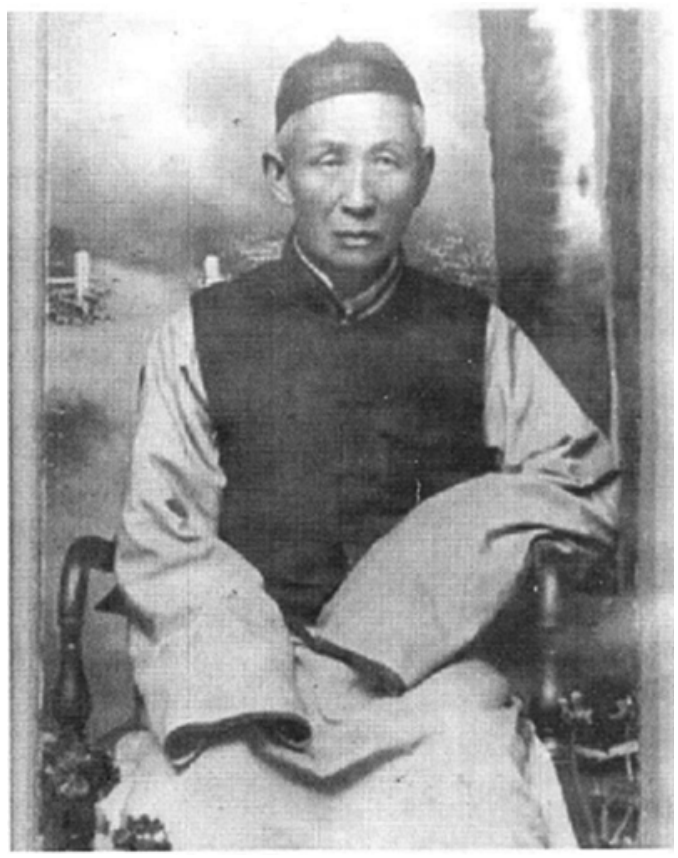

This research unit had excavated an area named Erin Davst located near the Gobi Gurvan Saikhan Mountains of Umnugobi Aimag and found a number of very rare findings in large quantities. This excavation caused a great stir among the world scientific community at that time. In accordance with the agreement signed with the Institute of Sutras and Scripts, this research unit left most of its findings in Mongolia. Currently, these very rare findings are kept in the storage facility of the Mongolia Natural History Museum. However, this research unit led by R.C. Andrews took with them a number of its findings without leaving them in Mongolia (Tsendsuren 2014: 29). Currently, these findings are kept in the storage facility of the Natural History Museum in New York.

These measures organized by the Institute of Sutras and Scripts in the mid-1920s were of great importance in the establishment of a museum in Mongolia. Thus, a first modern day of exhibition started in Mongolia on December 25, 1924. At the beginning, O. Jamiyan (Fig. 1), chairman of the Institute of Sutras and Scripts, cochaired the museum. The People's Government on April 1, 1926 decided to transfer the Palace and goods and items utilized by VIII Bogd Javzandamba Khutgat to the possession of the museum. In the period of 1929-1930, confiscation of feudal property, goods, and items having museum significance was organized as the largest political campaign and these were during this period transferred to the museum stores. Owing to these measures, the newly set up stores of the museum were enriched with a great number of artefacts and items of museum significance.

However, the large-scale political campaigns that progressed in Mongolia from the middle of the 1920 s showed a greater negative impact on the activities for pres- 
ervation and conservation of historical and cultural memorial items. The Third Congress of the Mongolian People's Revolutionary Party (MPRP) took place in 1924. The MPRP was the sole governing political force at that time. All issues relating to politics, economics, and social life were fully determined by the policy and decision of this party. The Third Congress of the MPRP approved a document that went into history as the "Party's Course Line" (Lkhamsuren 1985: 53). This document determined the future developmental direction of Mongolia as a "non-bourgeois development path." It was the beginning of domination and rule of communistsocialist ideology in Mongolia. What is communist-socialist ideology? It is worth giving a few words regarding this ideology. Since the creation of private property, human society has been divided into two antagonist classes called the "exploiter class" and the "exploited class." An unreconcilable struggle has been taking place between these two classes. Karl Marx, founder of Marxist thought, wrote that the history of humanity is the history of class struggle. Culture is also differentiated into the "culture of the exploiter class" and the "culture of the exploited class." In terms of content and form, the culture of the exploiter class and the culture of the exploited class cannot be reconciled with each other. The culture of the exploiter class has always protected the interests of the exploiter class. Because the culture of the exploiter class will interfere and hamper the construction of a new society, it should be demolished. Instead, a new culture that protects the interests of the exploited class should be created. This is one of the main goals of socialist revolution. Destruction of the culture of the exploiter class, creation of a new socialist culture that protects the interests of exploited class and that expresses its worldview, and creation of a new socialist culture can be attained only through a cultural revolution. Therefore, any country that aims to create and establish a socialist society must necessarily implement a cultural revolution. Founders of the Marxist-Leninist doctrine teach that without cultural revolution, it is not possible to build rightful prospects for humanity, that is, a communist and socialist society. This is the main idea of communist-socialist ideology. Following the Third MPRP Congress, the immediate start was to implement its decision in actuality. Starting at this time, the cultural heritage of the Mongolian people, which had been created by many generations, was treated as the culture of the exploiter class and the culture of the exploited class in accordance with communist-socialist ideology. Thus, a cultural revolution started in Mongolia. Beginning this time, wearing of national clothes and use of decorations made of gold and silver were banned. In addition, Buddhist activities began to be banned. By the middle of the 1930s, large campaigns were organized against Buddhism; during this period, many hundreds of temples and monasteries were demolished and burned and senior monks were executed. Also, a number of historic themes, for instance, the history of the Great Mongol Empire, the history of the Golden Horde, and the "Golden Kinship" of Chinggis Khan, were banned from undergoing any research work. Studies in the above research fields must be made and examined as well as evaluated from the position of Marxist-Leninist teachings. Any kind of advocacy (a literary work, movie, drama, song, poem, fine art, museum exhibition, etc.) in the above themes was banned. No preservation or storing in museum stores was allowed for productions and works from the culture of the exploiter class. There was the trend 
that works from the culture of the exploiter class were not considered as cultural heritage. This way, it opened the channel to losing the cultural products created by the Mongols, and many historical and cultural heritages created by many generations of Mongol nomads began their passage over the Mongolian border. Many historical and cultural heritages that illegally left this country at that time are currently kept in the museums of European countries such as Britain, France, Finland, Denmark, Austria, Sweden, and Russia (Konagaya and Lkhagvasuren 2014: 76). The authority of communist-socialist ideology in Mongolia continued up to the 1990s. As dictated by this ideology, the main directions of museum activities in Mongolia dealt with the praising of social revolution and socialist society being built anew. Clear examples of museums with communist-socialist ideology were the Lenin Museum and the Museum of Revolution, established with the investment of many millions in the Mongolian national currency - the tugri- of the state budget. The Lenin Museum, which did not have even a single original exhibit, had forced visits by many dozens of persons each year. Even now, Mongolia is not fully rid of the influences of this ideology. In particular, the impact of communist-socialist ideology still clings tenaciously to the life of cultural and museum affairs.

\section{Changes and Innovations That Started in the Museum Field}

At the beginning of the 1990s, Mongolia had about 50 museums with the status of "state museum," "local country museum," and "specialized museum," and over 200 museums with the status of "local country study chamber" (Fig. 2). They house over

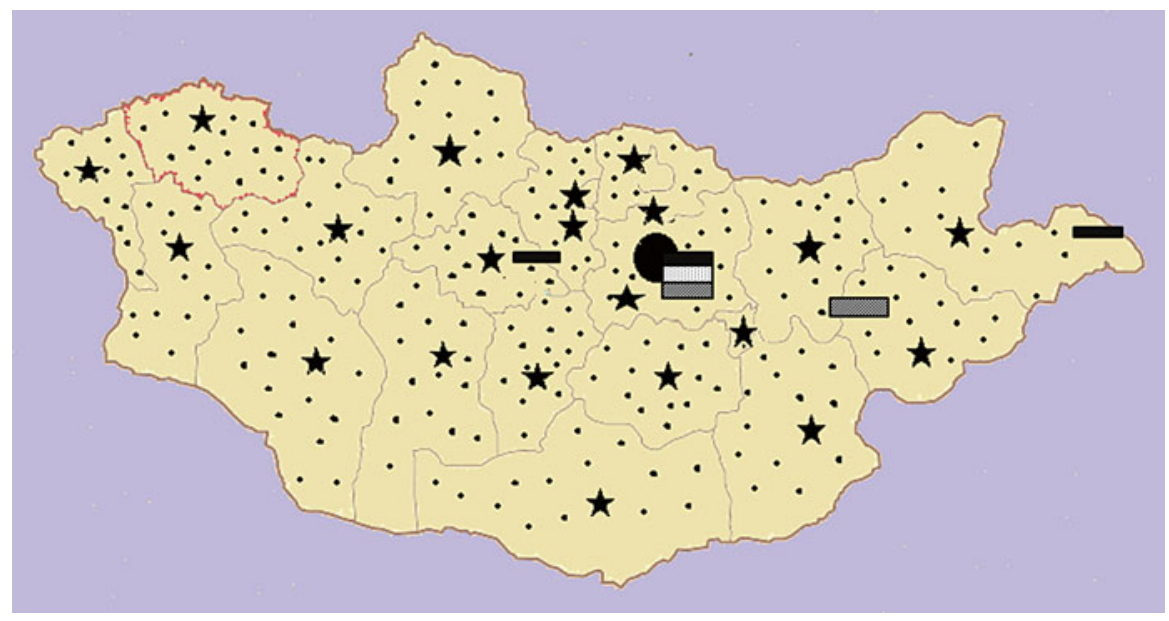

Fig. 2 Map of Mongolian museums (2015): local country study chambers (•), local country museums $(\star)$, state museums ( , specialized museums ( ) and the Authority for Museums (ZZZ), Ulaanbaatar capital ( 
a total of 270 thousand museum pieces and artefacts. There were no privately owned museums in Mongolia at that time. The Authority for Museums under the Ministry of Culture managed the activities for state and local country museums (Burnee 1994: 32).

The democratic movement has spread in Mongolia since the 1990s, and the larger changes were brought about in the field of culture, particularly the preservation and conservation of historic and cultural objects as well as in the activities of museums. First of all, the activities of museums needed to be freed from the influences of communist-socialist ideology. The aim of activities of museums was to find historical and cultural objects, register such objects into the museum collections, organize works for the preservation and conservation of museum objects, draw these objects into the cycle of scientific research, and promote public advocacy of museum goals. It was required to improve the working conditions in museums (i.e., setting up special buildings for museums), to innovate the equipment and furniture of currently operating museums, and to prepare professionals for the museums. In addition, it was required to actively participate in international cooperation between museums, and to expand the former international relations that were restricted only to the museums of socialist countries. In contrast, it was required to establish direct contact with many museums of other nations. Another goal put forward during this period was the creation of possibilities for setting up museums under private ownership. In order to implement these goals, it was required to take many measures in due order while not losing time.

In order to implement all of these works, the new democratic government started its job by the dismissal of the Authority for Museums in 1992. The Authority for Museums under the Ministry of Culture was in the first place created in order to coordinate activities for the state and local country museums. However, with time, this institution had gained strong control over the activities of museums by exercising communist-socialist ideology and made museums lose their autonomy and created a great number of obstacles in their activities. People were strongly critical of the functions of this institution and urged for its dismissal. With the dissolution of the Authority for Museums, the Ministry of Culture started conducting direct management of museum activities.

The second important decision implemented by the Ministry of Culture was the dismissal of some museums established in the first place in harmony with communist-socialist ideology. Within the frame of work, in the first order, the Museum of Revolution, State Central Museum, and Lenin Museum were targets for dismissal. In respect of the Lenin Museum, without the status of state museum, it functioned under the affiliation of the MPRP-the governing political party at that time. At the beginning of 1991, the Steering Council of the MPRP requested the Ministry of Culture to accord the status of state museum to the Lenin Museum, and to change its affiliation status from the MPRP to the Ministry of Culture. However, the Ministry of Culture gave a negative reply to this request. As to the replacement of dissolved museums, the Ministry of Culture decided to establish the Museum of Natural History (1991) and Museum of National History (1991). In addition, it was decided to establish a number of museums anew that include the Fine Arts Gallery 


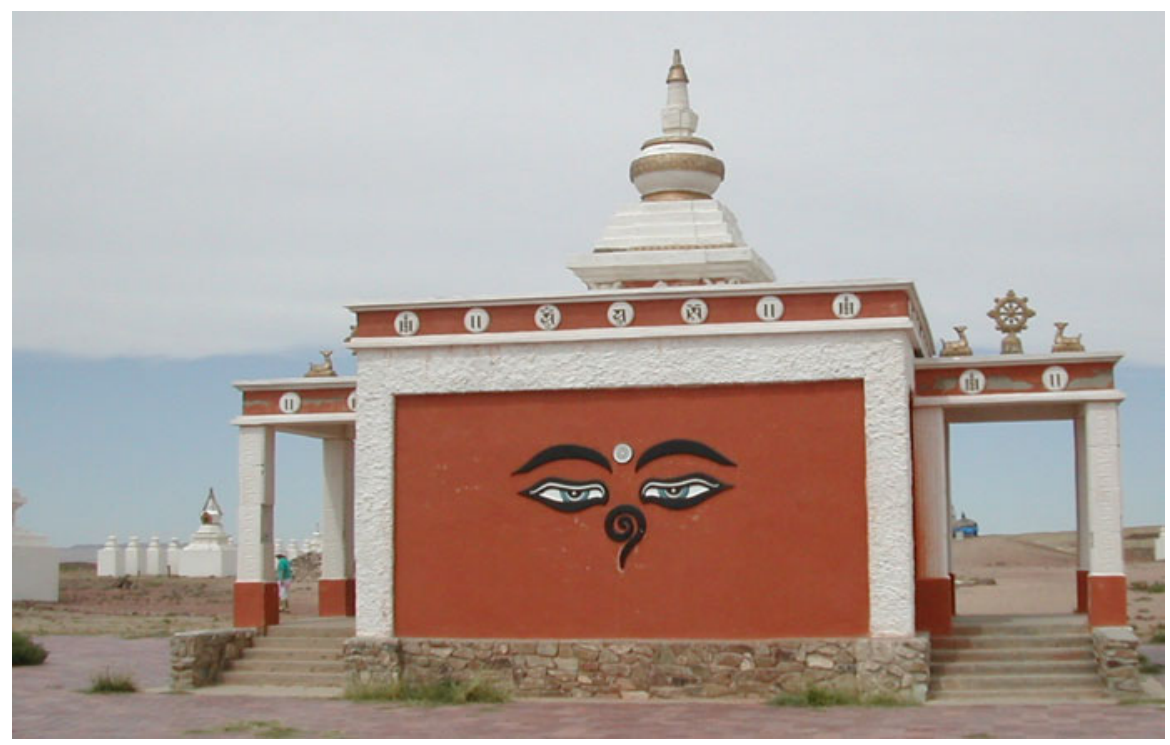

Fig. 3 Museum of Noyon Khutagtu

(1991), Museum of Theatre Arts (1991), and Museum of Choijin Lama Temple (2000). Later on, the Museum of Kharakhorum (2009) and Museum of Khushuu Tsaidam (2010) were also set up anew. A decision to establish the Museum of Dinosaurs was issued in 2013 and preparatory works are currently underway.

Since the 1990s, the goal of establishing museums under private ownership started for the first time in Mongolia. Currently, a number of museums under private ownership are conducting their activities. These include the Museum of International Intellectuality, Museum of Noyon Khutagtu (1991) (Fig. 3), and Museum of the Heritage of Chinggis Khan (2006).

\subsection{The Museum of Natural History}

With the dissolution of the State Central Museum in 1991, to replace it, it was decided to set up a Museum of Natural History. The State Central Museum was first established in 1956 and consisted of two sections: the Natural History Section and the History and Ethnicity Section. By the way of expanding its Natural History Section, an independent Museum of Natural History was established. A collection of exhibits for the Natural History Section had already started from the middle of the 1920s. The very rare paleontological findings by the third Asian expedition led by R. Chapman Andrews, American scholar and researcher on Central Asia, findings of flora and fauna, minerals, items, and museum pieces, themed naturalistically and collected by the researchers of Institute of Sutras and Scripts, were housed 


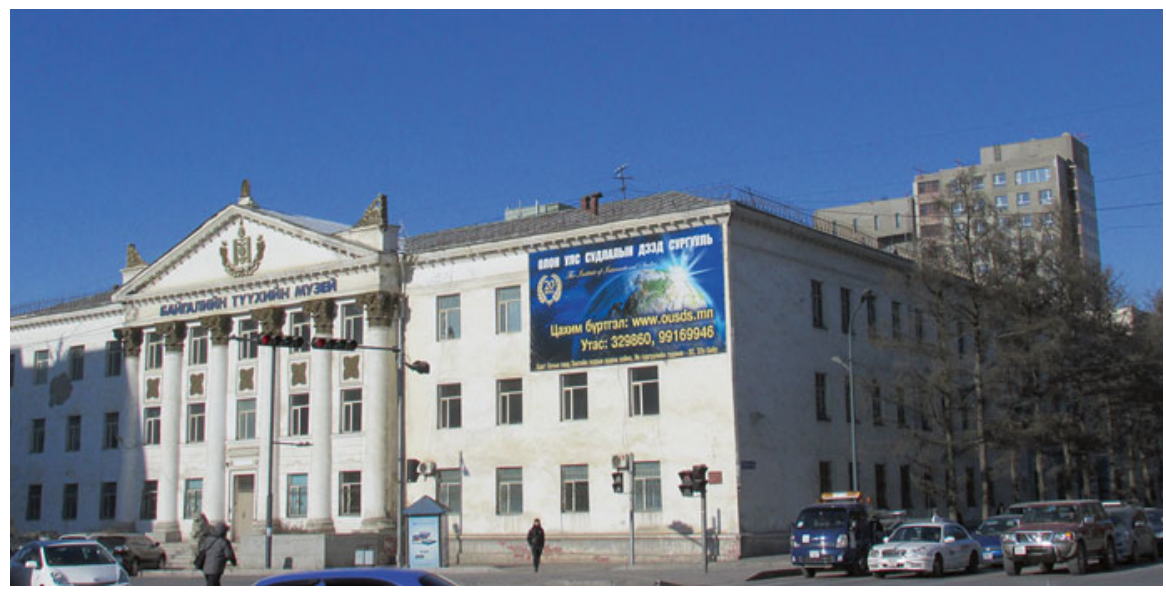

Fig. 4 The Museum of Natural History

in this museum. In 1991, when the State Central Museum was dissolved, its Natural History Section was storing over 8,000 museum pieces and artifacts.

The newly set up Museum of Natural History made large changes in the ways of displaying museum exhibits and in the way of arranging the museum halls. Prior to the 1990s, photos were mainly used as exhibits in the planning of museum halls, and original objects and exhibits were rarely used. The newly established Museum of Natural History aimed to use predominately original objects and museum pieces in the arrangement of exhibits in the museum halls. Currently, the museum halls are divided into eight main themes: (1) Hall of Physical Geography of Mongolia; (2) Hall of Geology and Mineral Resources of Mongolia; (3) Hall of Birds of Mongolia; (4) Hall of Flora of Mongolia; (5) Hall of Insects and Amphibians; (6) Mammals of Mongolia; (7) Hall of Paleontology; and (8) Hall of Human Origins. About $37 \%$ of all collections are shown as exhibits in the halls of the museum (Myandas 2014: 287).

Currently, this museum is conducting its activities in the building of the State Central Museum that was dissolved earlier (Fig. 4). This building was first built as a special professional school in 1954. The State Central Museum has been functioning in the same building since its opening in 1956 and until its dissolution in 1991.

\subsection{The National Museum of Mongolia}

With the dissolution of the Museum of Revolution in 1991, it was replaced by the National History Museum. The History and Ethnicity Section from the dissolved State Central Museum has been joined with the Museum of Revolution and by way of such expansion, a new National History Museum was created. A collection of exhibits for the History and Ethnicity Section of the State Central Museum had already started from the1920s. The very rare and interesting collections of museum 
pieces and artifacts relating to Mongol history and ethnicity and gathered by researchers from the Institute of Sutras and Scripts were housed at this museum. In addition, some findings by the Mongol and Tibet expedition organized by the Academy of Sciences of the Russian Federation were also kept at this museum. The dissolved Museum of Revolution first established in 1971 on the occasion of the 50th anniversary of the People's Revolution presented itself as museum of pure political ideology. The museum had been working with the goal of advocating the progress of socialist construction after the victory of the 1921 People's Revolution in Mongolia, and publicizing the achievements of socialism and educating the youth to become trustworthy citizens with the ideals of communism and socialism.

In 1991, when the Museum of Revolution was dissolved, a total of 13,000 museum pieces and artifacts were kept at the museum. The newly set up Museum of National History is the first full-scale independent museum on Mongolian history and ethnicity. Prior to this, Mongolia did not have an independent museum relating to Mongolian history and ethnicity. The MPRP considered that the setting up of a full-scale and independent museum on Mongolian history and ethnicity would not conform to communist-socialist ideology. The newly established Museum of National History consisted of two sections: the Mongolian History Section and the Mongolian Ethnicity Section. This museum had completed large changes in the way of organizing the museum halls. Currently, this museum arranges its museum halls into 10 themes of Mongolian history and ethnicity: (1) Ancient Mongolia; (2) Period of Early States Created in the Territory of Mongolia; (3) Period of the Mongolian Empire; (4) Mongolia during the XVII-XX Centuries; (5) Mongolia during the Period of 1911-1921; (6) Mongolia during the Period of Socialism; (7) Mongolia at the Start of the Democratic Movement; (8) Mongolian Traditional Economy: Livelihood, Animal Husbandry, and Agriculture; (9) Mongolia's Traditional Material Culture: Ger (apartment), Board and Lodging; and (10) Mongolia's Traditional Textiles and Decorations (Saruulbuyan 2009: 7). Currently, over 50,000 museum pieces and artifacts on Mongolian history and ethnicity are housed at this museum.

This museum is now conducting its activities at the building of the Museum of Revolution dissolved in 1991. This Museum of Revolution was first built on the occasion of 50th Anniversary of the People's Revolution in 1971. This is the first building in Mongolia built specially for the purpose of a museum. By the decision of the Ministry of Culture, the National History Museum has been renamed the National Museum of Mongolia (Fig. 5).

\section{Changes Taking Place in Museum Collections}

Prior to the 1990s, the main goal of enriching the museum collection was to advocate and publicize those changes that took place in politics, economics, and social life during the period of the socialist revolution, and the achievements during the construction of a socialist society (Baarai and Tumur-Ochir 1975: 8-14). 


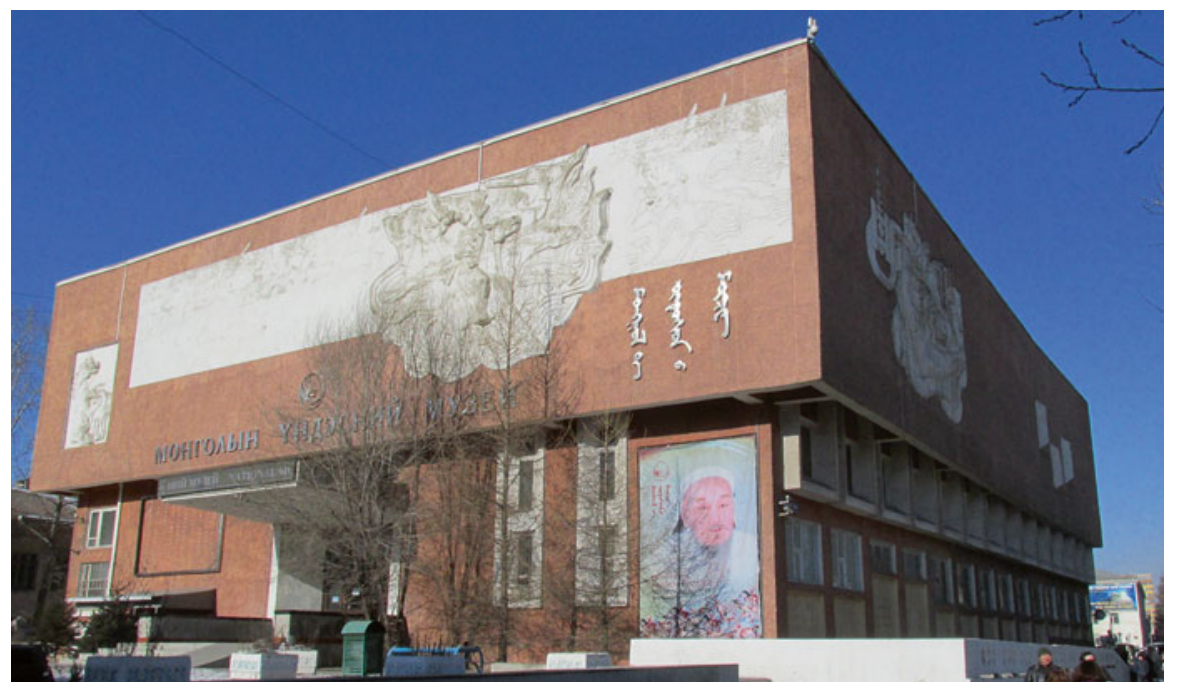

Fig. 5 The National Museum of Mongolia

At that time, work for the collection of museum pieces and artifacts was performed in two forms at the state and local country museums: (1) Employees of the museum would buy items or goods with museum significance in line with predetermined themes of revolution. With that purpose, collection of items with museum significance was organized for a certain period in certain local areas, towns, and settlements; (2) Institutions and private individuals would donate museum items with museum significance (Yadamsuren 1968: 10-16).

Buying of new items and goods with museum significance for the museum collection, particularly in Ulaanbaatar, was organized under the control of the Authority for Museums, Ministry of Culture. The Authority for Museums would buy items and goods with museum significance and they were distributed to individual museums in accordance with themes. It was certain that the Authority for Museums used socialist-communist ideology as guidance when they bought museum items for the museum collections. About $75-80 \%$ of all new items and goods coming into the state and local country museums were items and goods related to the themes of revolution.

Since the dissolution of the Authority for Museums in 1991, the museums have started individually deciding on new items and goods that they buy for their collections. In 1995, by a resolution of the Minister of Culture, the "Rules for Finding Historic and Cultural Items and Conducting their Researches" were approved. With the approval of these "Rules," a "Commission on the Purchase and Pricing of Exhibits" was set up under each museum. Activities under these commissions were supervised by directors of museums, and museum employees were in the composition of the commission. These commissions had the authority to purchase new items for the museum collection. With such a change, a museum could purchase museum items that would fit the main theme of the museum's activities. As mentioned above, 
starting from the middle of the 1920s, wearing the Mongolian national deel (clothing) and decorations made of gold and silver was prohibited. Because self-use was prohibited and even giving them to museums was not welcomed, some private persons used to store articles or items made of silver or gold in their homes. It is now possible for a museum to purchase those goods and items with museum significance that were stored at hands of private persons with the approval of the "Rules for Finding Historic and Cultural Items and Conducting their Researches." It also came to be in the interests of individuals to sell to a museum those items that have lost the value of their earlier utility. Thus, Mongolia's museums started obtaining some items that were previously impossible to acquire due to ideological barriers during socialism.

After the 1990s, another new form of enriching museum collections appeared. In 1995, a resolution of the Minister of Culture approved the "Rules for Conducting Archaeological Researches and Excavation." In accordance with the former Rules, the Ministry of Culture would provide a permit for the undertaking of archaeological studies and performing of archaeological excavations only to professional scientific institutions. By these new Rules, museums with state status such as the National History Museum and the Museum of Natural History were allowed to undertake independent archaeological excavation. In addition, according to the new Rules, archaeological findings were to be transferred to the State Treasury Fund as well as to museum collections. With the approval of the new Rules, the National Museum of Mongolia was able to take part in all archaeological excavations conducted by the Institute of Archeology of the Academy of Sciences of Mongolia. For example, the National History Museum has successfully taken part in a number of archaeological excavations such as Orkhony Khushuu Tsaidam (2005), the ruins of the capital of the Mongolian Empire - Kharakhorum (2008), and Kherlengiin Khuduu Aral (Erdenebat 2012: 211-216). Findings of these excavations were transferred to the collection of the National Museum of Mongolia. In addition, the Museum of Natural History has taken part in fieldwork studies as well as excavations conducted by the Institute of Paleontology of the Mongolian Academy of Sciences. No such possibilities were presented to any museum that was functioning prior to the 1990s in Mongolia.

From the 1990s, the financial capacity for enriching museum collections has significantly declined due to the economic crisis in Mongolia. At this time, owing to financial constraints, museums had a policy of buying few items and only those with great museum significance. Although the financial capacity of museums decreased during this period, museums were continuously enriching their collections. For example, the Zanabazar Museum of Fine Arts bought 700 items that were consistent with its profile of activities over the period last 20 years. About $60 \%$ of these new items the museum bought through its own Commission on the Purchase and Pricing of Exhibits (Uranchimeg 2014: 218). Figure 6 shows how the enrichment of museum exhibits was conducted at the Zanabazar Museum of Fine Arts Gallery. In 1998, there is a temporary decrease in the number of collection because the Museum of Contemporary Art became independent from the Zanabazar Museum of Fine Arts. 


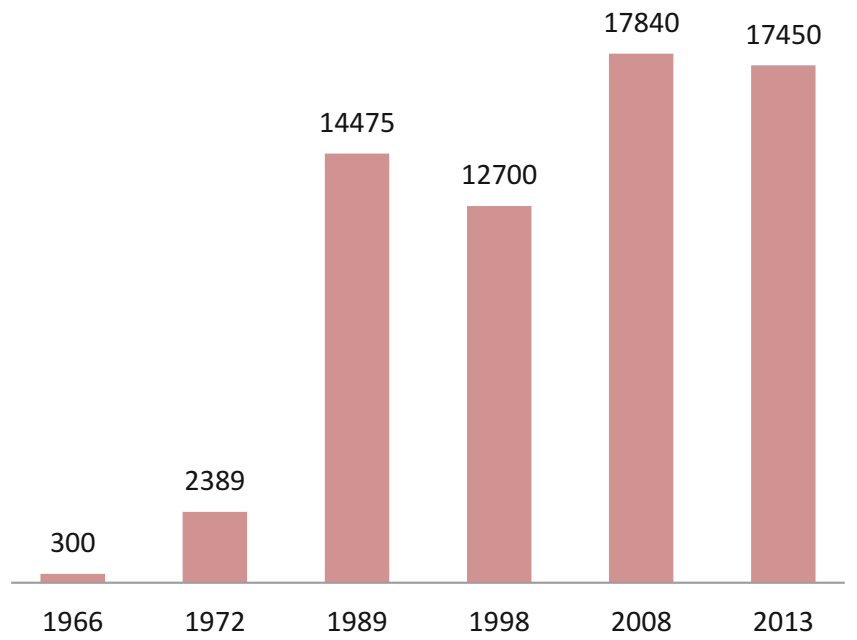

Fig. 6 Collection of the Zanabazar Museum of Fine Arts since 1966

In addition to financial difficulties, there was an additional factor influencing the decrease in new museum items and artifacts being obtained by the state museums. In 1994, a resolution of the Minister of Culture approved the "Rules on Purchase and Exchange of Historical and Cultural Items." With the approval of these Rules, antiques sales started all over the country through antiques shops. Prior to the 1990s, antiques sales were banned in Mongolia. Under a permit issued by the Ministry of Culture, private individuals and companies were entitled to run an antiques business. With the start of antiques sales, private individuals who possessed pieces and items with museum significance have significantly reduced transferring or selling these pieces and items into the possession of state museums. The large discrepancy between the prices offered by museums and those by antiques shops in the purchase of historic and cultural pieces and items has certainly had an impact on the above situation. In addition, with the start of antiques sales, there were apparently many negative activities. Also, it was apparent that there were cases where individuals and companies who had no permit to conduct antiques business from the Ministry of Culture started selling antiques. A chain of illegal international antiques businesses started working in Mongolia. There were cases of selling pieces and items from a museum collection through illegal chains of antique businesses. For example, there was a case of a museum piece that was stored in the collection of the National Museum of Mongolia being sold through a chain of illegal antique businesses. Owing to this, Mongolian legal institutions later established that a total of 13 billion tugrik (according to the exchange rate of that time, the loss was equivalent to USD 13 million) in loss was incurred by the National Museum of Mongolia. This was a single largest organized crime in the modern history of museums. 
Not only were museum pieces and items sold but there were also cases of nonmuseum items having been sold through this chain of illegal businesses. For example, non-legal paleontological excavation was organized in the southern part of Mongolia and a large number of findings from the excavation were sold through a transborder deal. The skeleton of a Tarbosaurus bataar that was found in southern Mongolia and obtained through a transborder purchase was in a New York auction in 2012 and was sold at the auction for about USD 100 million. At the request of the Mongolian side, the auction transaction was voided and a US district court issued a decision to return the Tarbosaurus bataar skeleton to Mongolia. The US court decided to return to Mongolia not only the Tarbosaurus bataar skeleton, but also the skeletons of 22 other dinosaurs that left Mongolia illegally in the 1990s (Tsendsuren 2014: 77-78).

Just recently, the world press and media informed us that a Green Tara created by Undur Gegeen Zanabazar was put up for auction and sold for three million euros. Since 2001, by a decision of the Government of Mongolia, all arts of Undur Gegeen Zanabazar and of his school have been ranked as "Unique and Priceless" historical and cultural memorials. The Ministry of Culture, Sports and Tourism of Mongolia expressed its protest against this auction in Paris although the organizers of this auction sale did not receive a complaint from the Government of Mongolia. Currently, it is not known when this artwork of Zanabazar left Mongolia. By now, however, there are no conditions under which similar crimes could possibly be repeated in the future.

As I have mentioned above, starting in the middle of the 1920s, Mongolian historical and cultural memorial items illegally left Mongolia to go abroad. Starting only in the 1990s did the Ministry of Culture raise the issue of returning to Mongolia those historical and cultural objects that left the country illegally. However, implementation of this issue has yet to be started. There are a variety of reasons, both dependent and independent, on the Mongolian side. First of all, the Mongolian audience expresses the opinion that the raising this issue is not well prepared when Mongolia's museums are not well organized and the conditions for the secure preservation and conservation of museum pieces do not meet the required standards.

Amongst new items that have replenished Mongolia's museum collections since the 1990s, the percentage of items and museum pieces with themes of revolution has been significantly reduced. Although no statistical data are available in respect of the percentage of newly arrived museum items associated with revolutionary themes, there is a belief that it has been significantly reduced. In this connection, it must be said that no similar museum statistics are available in Mongolia. With the dissolution of museums such as the State Central Museum, Museum of Revolution, and Lenin Museum, which had conducted their museum activities under revolutionary themes, it is evident that this greatly influenced the decrease in the percentage of revolutionary content amongst the total number of newly arrived items in the scale of the entire country. 


\section{Issues and New Trends in Respect of Registration and Documentation of Museum Collections}

Prior to the 1990s, the proper registration and documentation of museum collections in Mongolia was a neglected task. During that period, a registration card was filed for a museum collection piece. The content of the registration card was approved by the Ministry of Culture and it was required for all museums with state or local country status. The registration card contained a photo of the museum piece or item, name, purpose, reason for being kept in the museum, and its scientific description. However, there was no information regarding size, form of the museum piece, or materials that it was made of. However, most of the museums did not file registration cards at all and if did do so, they did not do it well. There are many reasons for this. A major reason is that the museum itself did not conduct any research work and museum employees were non-professionals. Therefore, among the museum pieces, there were many indeterminate questions that not just anyone could answer easily: what it is, what it is called, who, when, and for what purpose was it made, and when and why it entered the collection.

Starting in the 1990s, innovations have started in the ways of registration and documentation of museum collection items. In 1994, the "Law on Conservation of Historical and Cultural Artifacts" was approved. The Law had a provision for creating a "State Registration and Information Database on Historical and Cultural Artifacts." Following this, the "Rules for the Creation of State Registration and Information Database on Historical and Cultural Artifacts" were approved by a resolution of the Minister of Culture. With the approval of the Rules, innovation of registration cards for museum collections has started all over the country. The Ministry of Culture has approved the State Registration Card of Historical and Cultural Artifacts of Mongolia (Form No. 1) and has ordered all the museums of Mongolia to compile the card. After that, the Ministry of Culture decide to create the Center of Cultural Heritage by expanding the composition and structure of "Reconstruction Artistry for Museum Exhibits." Within the newly established Center of Culture Heritage, it has been decided to set up a State Registration and Information Database. At the beginning, the registration card for museum collections was compiled in two copies: one to be retained by the museum itself and the other to be sent to the newly established Center of Culture Heritage. However, this work has encountered a number of difficulties and is progressing quite slowly. Starting in 2005, Mongolia's government began implementing the "Program on Digitalized Storage of National Cultural Heritage Information." Within the frame of this program, based on the registration card for museum collections compiled for all museums, a software program called $\mathrm{RCH}$ or Registration of Cultural Heritage 1.0 was designed. State and local country museums have been provided with the $\mathrm{RCH}$ or Registration of Cultural Heritage software program along with computers and the other required technical equipment. A total of 38 museums with local country status that conduct their activities in 21 aimags have been included in this project. Starting in 2010, a revised version of the $\mathrm{RCH} 2.0$ software program was implemented into practice. 


\section{Issues for the Preservation and Conservation of Museum Items}

One of the main functions for any museum is the preservation and conservation of museum collections employing scientific methods and methodology. About $90 \%$ of all museums functioning prior to the 1990s conducted their activities in buildings that were not specially designed for museum purposes. Amongst the museums with state status that were functioning in Ulaanbaatar at that time, the Museum of Revolution functioned in a special museum building. Another museum functioning in a special museum building was the Lenin Museum. However, this museum did not hold state status but was functioning under the MPRP - the governing political party at that moment in time. With respect to local country museums, the situation was no different to that above. Although there were some cases of local administration building new buildings for their local country museums, these cases were only very few (Lkhagvasuren and Konagaya 2007: 65). For museums not located in specially designed museum buildings, it is clear that the ways of preservation and conservation do not meet the conditions and requirements of safety standards for specific museum pieces and items. For museums of that period, the following general flaws were evident:

1. Rooms for museum collections were small, and had no shelves or special boxes designed for safe storage of museum pieces.

2. No registration of museum pieces was done in respect of themes or materials and all museum pieces were stored all along together.

3. Temperature, relative humidity, and air content of rooms, where museum pieces were stored, were not controlled or regulated at all.

4. Insecticidal procedures for rooms in which museum pieces were stored were hardly ever done.

5. Museums never conducted any reconstruction activities for museum pieces and items.

These obligatory jobs that should be conducted in the storage rooms of museum pieces were almost never done; as result, occurrences of damage, color loss, and infection with insects were quite commonplace. Since the 1990s, the first steps were taken to fix the above situation. The Ministry of Culture approved a number of documents: "Bylaw for Museum Collections of Mongolia" in 2005, "Requirements for Museum Affairs: The Standard of Mongolia" in 2006, "Bylaw for Local Country Museums" in 2009, and "Instructions for Registration and Documentation of Museum Collections" in 2012. The main goal of all of these documents was to improve the conditions of conservation of museum pieces and elaborate the registration documents of museum pieces. Before this time, Mongolian museums did not classify the museum pieces by materials from which the given museum pieces were made; rather, they classified museum items as "made of soft material" and "made of hard material." After the issuance of the above documents, the largest state museums start classifying collections of their museums in accordance with themes. For 
example, collections of the National History Museum were classified into three main themes: (1) Collection of Precious Items (items made of gold and silver and items with religious themes); (2) Collection of History and Archaeology; and (3) Collection of Ethnology. Items under each collection started being stored separately from each other. After classifying the museum items in accordance with the corresponding themes, within each collection, items started being classified in accordance with the materials from which they were made. For example, items made of hard materials were classified as items made of metal, stone, and wood; each of them were separated and started being stored separately. In addition, items made of soft materials such as cotton started being considered as one group and stored separately. Metallic shelves and wooden boxes were placed to store museum pieces individually. Measures were taken to protect items placed on the shelves from dust (for instance, some items were covered by a sheet of cotton). Most museum pieces were placed inside carton boxes and put on metallic shelves. In addition, in each collection room, each metallic and wooden shelf inside the rooms was numbered. After this numbering, measures were put in place to easily understand and locate which items are kept in which rooms and on which shelves. Lately, there is the apparent trend that the materials of museum pieces are classified as being made of "organic-quality" and "non-organic-quality" materials. UNESCO projects have been implemented at some museums such as the Zanabazar Museum of Fine Arts and conditions of storage of museum pieces have significantly improved (Uranchimeg 2014: 218-228). Some museums have started utilizing room airconditioning and room air relative humidity regulation equipment that were produced in such countries as Germany. However, insecticidal procedures are lagging rather far behind. In accordance with the "Law on Conservation of Historical and Cultural Artifacts," which was approved in 1994, historical and cultural artifacts were graded as "Unique and Priceless," "Precious," and "Ordinary" (Enkhbayar 1996: 83). Along with this law, the "Rules of the Professional Council for Determination of Grade and Price of Historic and Cultural Memorial Items" were approved. According to these Rules, the Professional Council for Determination of Grade and Price of Historic and Cultural Memorial Items was set up. The composition of this Council consisted of specialists from the Institute of History, Institute of Archaeology, Institute of Geology, Institute for Culture and Arts, Archives Administration, and Center for Cultural Heritage of Mongolia. After the approval of the "Law on Conservation of Historical and Cultural Artifacts," museums with state or local country status reviewed all of their museum collections and determined each of their museum items in accordance with grades of "Unique and Priceless," "Precious," and "Ordinary" and started paying due attention to the storage conditions of those items. Currently, there are 250 museum pieces graded as "Unique and Priceless" that are stored at the museums with state or local country status. Mongolia's museums are conducting quite a lot of work for the proper preservation and conservation of museum pieces but this work has still not yet reached the required standard. 


\section{International Cooperation of Museums and New Trends}

Since the 1990s, Mongolia's museum institutions have been actively engaged in cooperation with international museum institutions. Relations that were active only with museums of former socialist countries, particularly those of Eastern European and those of the former Soviet Union, have now been expanded further and new opportunities have opened to establish ties with museums of many other nations. During this time, the Mongolian Museums Union was established to become a member of international museum institutions such as ICOM and ICCROM. Opportunities opened for Mongolia's museum employees to regularly take part in international seminars and meetings organized by these international museum institutions. In addition, opportunities have opened for Mongolia's museum employees to regularly take part in training at museums in Germany, Denmark, Finland, and the USA to upgrade their professional skills and qualifications and learn from their experience.

Since September 1994, Mongolian museum associates have regularly taken part in the international training courses on museology that take place at the National Museum of Ethnology in Osaka (hereafter referred as Minpaku) under the financial support of JICA - the Japan International Cooperation Agency. Currently, over ten specialists from Mongolian museums have participated in the activities of this seminar. They are (1) D. Tsedmaa- Ministry of Education, Culture, and Science (MECS) (1994); (2) I. Lkhagvasuren-National History Museum (1994); (3) Z. Oyunbileg-MECS (1999); (4) D. Enkhtsetseg-Fine Arts gallery (2002); (5) Ch. Natsagnyam-Kharakhorum Museum (2009); (6) B. Ulziibayar-Mongolian Theatre Arts Museum (2009); (7) A. Yanjiv-Culture Arts Committee (2010); (8) J. Myandas-Natural History Museum (2010); (9) Ts. Oyunkhishig-National Museum (2011); (10) D. Narantuya-Culture Heritage Center (2011); and (11) G. Yalalt-Fine Arts Gallery (2011). Most of the specialists taking part in museum training are currently working in this field and it is gratifying to note that they continue adding their contributions to museum affairs and advocating the development of proper preservation and conservation of museum items. In addition, four training seminars have been organized for museum employees in Ulaanbaatar. They are as follows:

- Seminar on "Methodology of Preservation and Conservation of Historical and Cultural Memorials," from April 1 to April 7, 1996.

- Seminar on "Classification and Generalization of Museum Pieces," from April 1 to April 7, 1997.

- Seminar on "Registration of Museum Collections and Its Significance," from April 1 to April 8, 1998.

- Seminar on "Method of Using Digital Technology in the Creation of a Registration and Information Database for Historical and Cultural Memorials and Its Significance," from July 2 to 3, 2000. 
These seminars, which had important implications and significance for the upgrading of the professional skills of Mongolian museum employees, were led and conducted by Professor T. Morita from the National Museum of Ethnology, Japan.

Since the 1990s, Mongolia's museums have actively engaged in the organization of international exhibitions abroad. Formerly, organization of international exhibitions was restricted to only former socialist countries, but from this period, this restriction was further lifted so that organization of exhibitions on Mongolian history and ethnicity as well as on paleontological themes can take place in many countries of the world. The first large-scale exhibition on Mongolian history and ethnology opened in Munich, Germany in 1989. Since then, over ten exhibitions on Mongolian history and ethnology opened in a number of countries such as the USA, France, and Japan. In addition, a thematic exhibition on Mongolian dinosaurs was successfully organized in many countries of the world.

\section{Conclusions}

The first museum in Mongolia started its activities on December 25, 1924. Starting in the middle of the 1920s, Mongolian cultural heritage, created over many generations, has been treated from the angle of communist-socialist ideology as belonging to the culture of the exploiter class and the culture of the exploited class. Until the 1990s, the museum affairs of Mongolia were dictated and dominated by communistsocialist ideology and advocacy of achievements in the construction of the socialist revolution and praising of a socialist-communist society - the rightful future of humanity-were the main guidelines for the museum activities of Mongolia.

The democratic movement started in the 1990s and the first steps were taken to bring about larger changes in the field of culture, particularly for the protection and conservation of historic and cultural heritage as well as for the museum affairs of Mongolia. First of all, museum activities were to find historical and cultural objects, register such objects into the museum collections, organize work for the preservation and conservation of museum objects, draw these objects into the cycle of scientific research, and promote public advocacy of museum goals. Although Mongolia's museums have made quite an achievement in the implementation of the above goals, there are still many goals that need to be accomplished.

Open Access This chapter is distributed under the terms of the Creative Commons AttributionNonCommercial 4.0 International License (http://creativecommons.org/licenses/by-nc/4.0/), which permits any noncommercial use, duplication, adaptation, distribution and reproduction in any medium or format, as long as you give appropriate credit to the original author(s) and the source, provide a link to the Creative Commons license and indicate if changes were made.

The images or other third party material in this chapter are included in the work's Creative Commons license, unless indicated otherwise in the credit line; if such material is not included in the work's Creative Commons license and the respective action is not permitted by statutory regulation, users will need to obtain permission from the license holder to duplicate, adapt or reproduce the material. 


\section{References}

Baarai, S., and S. Tumur-Ochir. 1975. History of origin and development of the State Central Museum. 5(3): 8-14. (In Mongolian).

Burnee, U. 1994. National History Museum of Contemporary Mongolia. Ulaanbaatar: State Publishing House. (In Mongolian).

Enkhbayar, N. (ed.). 1996. Culture and arts under new conditions. Ulaanbaatar: State Publishing House. (In Mongolian).

Erdenebat, U. 2012. Basis of archeology and research methods. Ulaanbaatar: Soyombo Printing Co. Ltd.. (In Mongolian).

Konagaya, Y., and I. Lkhagvasuren. 2014. Studies on material culture of Mongols - Nomads. In Cultural Heritage of Mongols, ed. S. Chuluun, 76-102. Ulaanbaatar: Admon Printing Co. Ltd.. (In Russian).

Konagaya, Y., S. Bayaraa, and I. Lkhagvasuren. eds. 2007. A.D.Simukov, Works about Mongolia and for Mongolia. Vol. 1 (SER 66). Osaka: National Museum of Ethnology. (In Russian).

Konagaya, Y., S. Bayaraa, and I. Lkhagvasuren. eds. 2008. A.D.Simukov, Works about Mongolia and for Mongolia. Vol. 3 (SER 75). Osaka: National Museum of Ethnology. (In Russian).

Lkhagvasuren, I., and Yuki Konagaya (eds.). 2007. Tsogt-Ochiriin Lookhuuz (SER 72). Osaka: National Museum of Ethnology. (In Japanese and Mongolian).

Lkhamsuren, B. (ed.). 1985. Brief history of Mongolian people's revolutionary party. Ulaanbaatar: State Publishing House. (In Mongolian).

Myandas, J. 2014. Origin of the Museum of Natural History. In New Horizons in Asian Museums and Museology, eds. Sonoda, N., Y. Konagaya, and I. Lkhagvasuren, 93-97 and 285-291. Ulaanbaatar: Admon Printing Co. Ltd. (In Japanese and Mongolian).

Saruulbuyan, J. (ed.). 2009. National Museum of Mongolia. Ulaanbaatar: Munkhiinuseg Printing Co. Ltd.. (In English).

Sereeter, C.H., K.H. Tserev, and B. Chadraa, eds. 2003. History of Academy of Sciences of Mongolia. Ulaanbaatar: Bembisan Printing Co. Ltd. (In Mongolian).

Tsendsuren. T.S. ed. 2014. History of Mongolian Museums. Ulaanbaatar: Admon Printing Co. Ltd. (In Mongolian).

Uranchimeg, D. 2014. Preservation of the collection at Zanabazar Art Museum. In New Horizons in Asian Museums and Museology, eds. Sonoda, N., Y. Konagaya, and I. Lkhagvasuren, 39-48 and 215-229. Ulaanbaatar: Admon Printing Co. Ltd. (In Japanese and Mongolian).

Yadamsuren, P. 1968. Mongolian museum studies. Museum Studies 4(5): 10-16. (In Mongolian). 


\title{
Policies for National Museum Management: Solutions and Development
}

\author{
Jarunee Incherdchai
}

\begin{abstract}
There are 41 national museums in Thailand. Since the Act on National Education of 1997, national museums have been expected to provide more educational services and facilities, but a lack of museum personnel and inadequate budgets remain big problems. Recently the decision was made to reduce the number of national museums, and the small-scale national museums, formerly monastery museums, have returned to being monastery museums. To improve the image of national museums, three pilot projects are undergoing: the first project is establishment of seven national museum storage units - a main central storage unit in Pathumthani Province and six regional national museum storage units -; the second project is renovation of the National Museum Bangkok; and the third project is development of the Kanchanaphisek National Museum which will represent all ethnic groups in Thailand.
\end{abstract}

\section{Background to National Museums in Thailand (Fine Arts Department, 2008)}

Looking back to 1874 , the first public museum originated at the Concordia Pavilion (Fig. 1) inside the Grand Palace and opened on the occasion of King Rama V's birthday celebrations (Fine Arts Department, 2008). The museum exhibited the royal collections of King Rama IV and other objects of general interest. Afterward, a special exhibition was opened regularly on His Majesty's birthday till 1887. It was transferred from the Palace to the Front Palace or "Wang Na," which had been the Palace of the Prince Successor, and was called the "Royal Museum at Wang Na" (Fig. 2) under the Museum Department, Ministry of Dhammakarn (Ministry of Education) (the former Ministry of Public Instruction, also in charge of religious affairs).

The management of the Royal Museum at Wang Na during the reign of King Rama V was progressive and systematic. The museum opened regularly on Wednesdays and Sundays from 10 am to 4 pm except on those days that shall fall on

J. Incherdchai $(\bowtie)$

Kanchanaphisek National Museum, Khlong 5 subdistrict, Khlong Luang district,

Pathumthani Province 12100, Thailand

e-mail: jajum@yahoo.com 

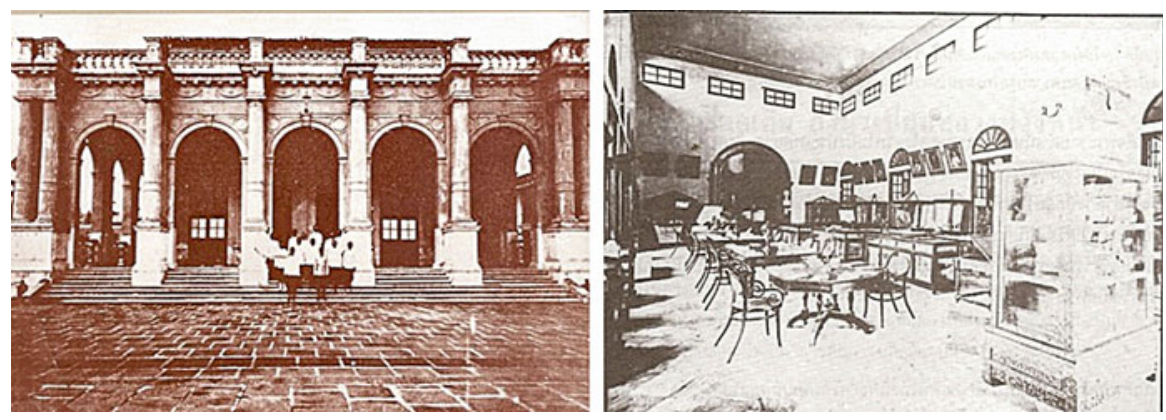

Fig. 1 The Royal Museum at the Concordia Pavilion, Royal Palace, during the reign of King Rama V
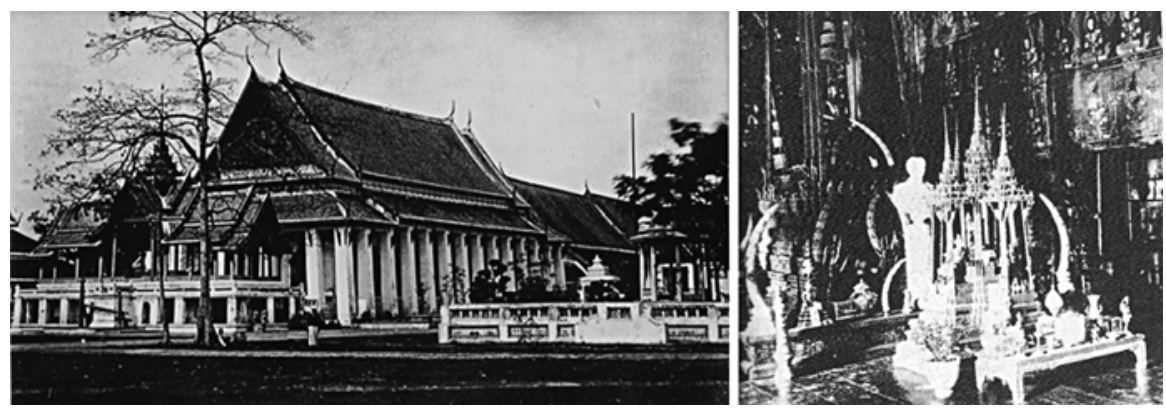

Fig. 2 The Buddhaisawan Chapel, a part of Royal Museum at Wang Na, during the reign of King Rama V

Siamese Sundays or Wan Phras. As the same time, the first museum located in the province was established; this was Ayutthaya Museum, modeled on other museums such as the monastery museums in Sukhothai and Nakhonpathom Provinces.

During the reign of King Rama VI, in 1912, museum was an important organization of the Fine Arts Department, which was under the direct auspices of His Majesty the King. There were more than 20 museums during the period and most of them were monastery museums. Prince Damrongrajanubhap was a key person running museum works until the subsequent reign. The status of museums was an institution to protect and preserve cultural heritage.

During the reign of King Rama VII, in 1925, the Royal Museum at Wang Na was changed to the Museum for Phranakhon (Fig. 3) by expanding the house of galleries inside other buildings of the palace. The public museum was opened formally on November 19, 1926. Under the Act on Establishment of the Museum for Phranakhon in 1926, more monastery museums in the provinces such as the Monastery Museum of Mahathat Phetchaburi, Monastery Museum of Phrathat Hariphunchai in Lamphun Province, and so on were built.

During the period of democracy, in 1934, the next museum act, i.e., the Act on Ancient Monuments, Objects of Art, Antiques and National Museums, 1934, was announced, the Museum for Phranakhon was changed to "National Museum 


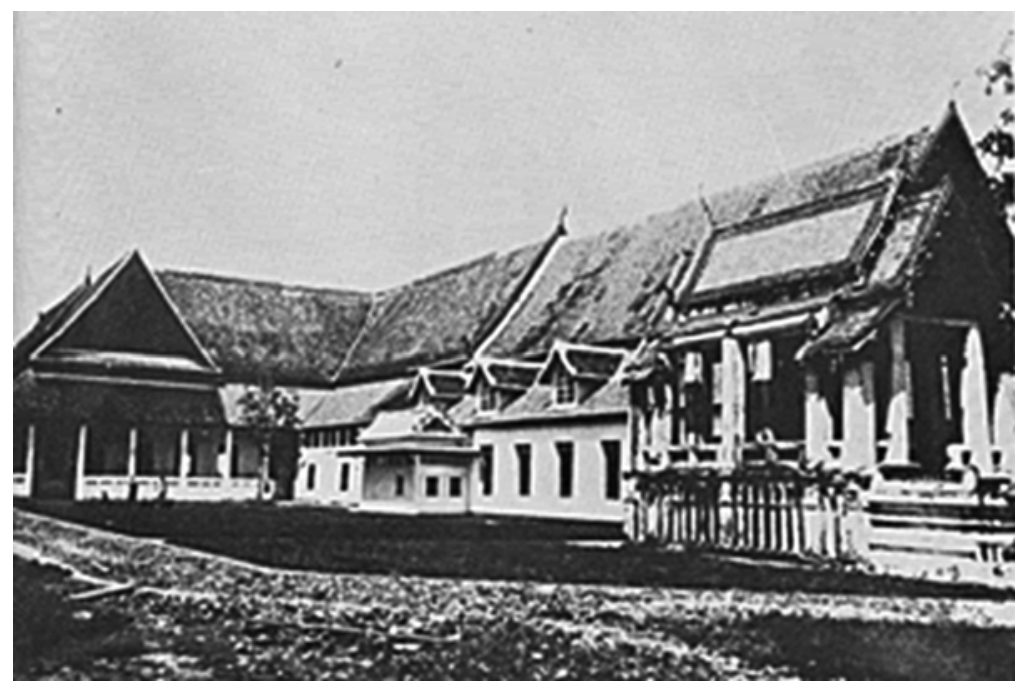

Fig. 3 Old Palace of Wang Na, as Museum for Phranakhon

Bangkok," and all museums established both before and after 1934, which were under the Fine Arts Department, now had the status of national museum.

\section{Role and Function of National Museums in Thailand}

The primary role of the museums was as a "reception hall" showing Siamese civilization to Westerners. Later, museums were a splendid place for appreciation and learning, as was King Rama V's intention. Anyhow, the protection, including the surveying, gathering, and collecting of cultural heritage, that is, ancient objects, was a major task led by King Rama VI. Museums such as the Royal Museum at Wang $\mathrm{Na}$, Ayutthaya Museum, Lopburi Museum, and Wat Mahathat Monastery Museum in Phetchaburi Province were places for keeping and preserving all national ancient objects.

The role of museums was extended to educational service in the following times, together with various national museums being set up, also according to the Act on Ancient Monuments, Objects of Art, Antiques and National Museums, 1934 (Fine Arts Department, 1998). During 1961-1974, national museums in Thailand underwent rapid growth because of the government's policy. A total 15 national museums together with 10 monastery museums were established in this period. Examples are as follows:

1. Chao Sam Phraya National Museum, Ayutthaya Province

2. Ramkhamhaeng National Museum, Sukhothai Province

3. U Thong National Museum, Suphanburi Province

4. New Building in the National Museum Bangkok 


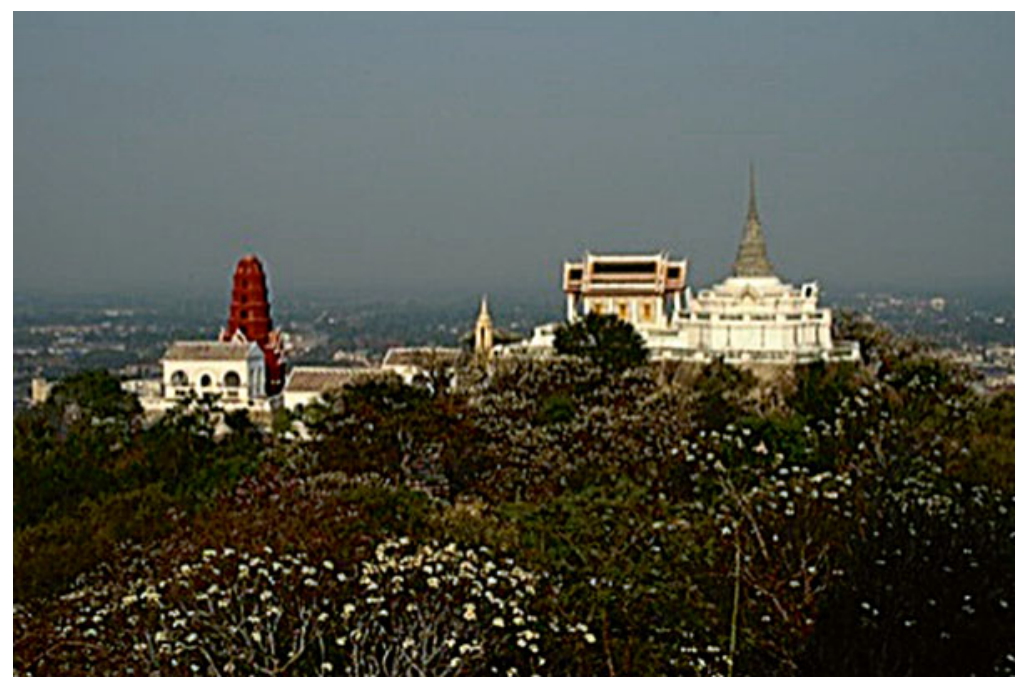

Fig. 4 Phanakhonkhiri National Museum, in Phetchaburi Province, old palace during the reign of King Rama V

5. Kamphaeng Phet National Museum, Kamphaeng Phet Province

6. Phrapathom Chedi National Museum, Nakhonpathom Province

7. Khon Kaen National Museum

8. Chiang Mai National Museum

9. Nakhon Si Thammarat National Museum

10. Ban Kao National Museum, Kanchanaburi Province

11. Ban Chiang National Museum, Udonthani Province

12. Phimai National Museum, Nakhonratchasima Province

13. Chiangsaen National Museum, Changrai Province

14. Hariphunchai National Museum, Lamphun Province (monastery museum)

15. Mahawerawong National Museum, Nakhoratchasima Province (monastery museum)

16. Inburi National Museum, Singburi Province (monastery museum)

17. Chainatmuni National Museum, Chainat Province (monastery museum)

18. Chaiya National Museum, Suratthani Province (monastery museum)

19. Matchimawat National Museum, Songkhla Province (monastery museum)

20. Phraphutthachinnarat National Museum, Phitsanulok Province (monastery museum)

During 1975-1995, the national museums started treating various different themes.

- Historical or memorial: Phanakhonkhiri National Museum (Old Palace) (Fig. 4), Phetchaburi Province and Silp Bhirasi Memorial, Bangkok.

- Contemporary art: The National Gallery, Bangkok (Fig. 5). 

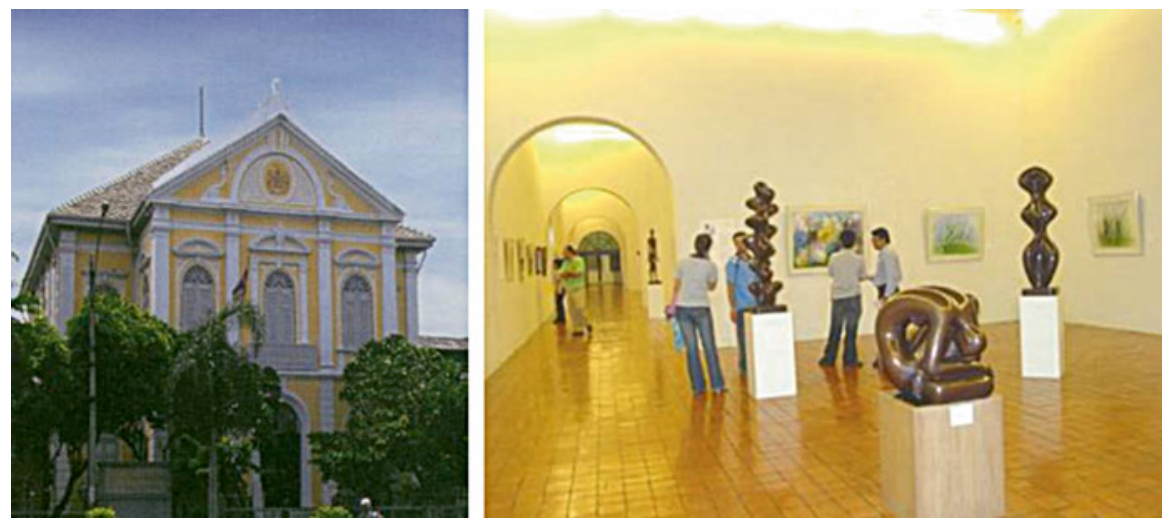

Fig. 5 The National Gallery, Bangkok
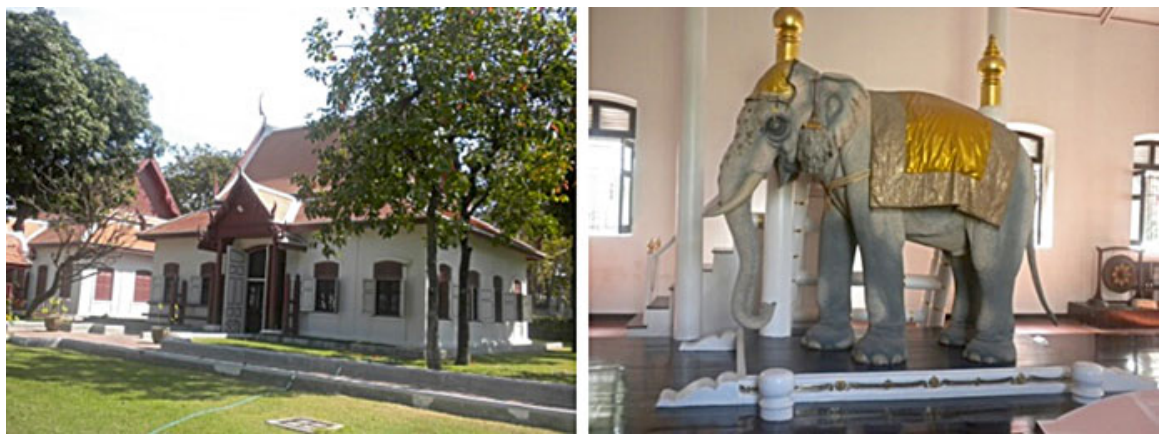

Fig. 6 The Royal Elephant National Museum in Bangkok

- Specialized museum: The Royal Barge National Museum in Bangkok, the Royal Elephant National Museum in Bangkok (Fig. 6), and the Thai Farmer National Museum in Suphanburi Province.

- City Museum: Ubonratchathani National Museum (Fig. 7), Surin National Museum, Nan National Museum, Ratchaburi National Museum, Suphanburi National Museum, and Roi-Et National Museum (Fine Arts Department, 2006).

Nowadays, there are 41 national museums over the whole country, caring for national heritage, ancient objects, art objects, and ethnographical objects, of which there are more than 300,000 pieces.

\section{Reasons for Developing National Museums}

According to the Act on National Education 1997, there are two main points related to museums. 


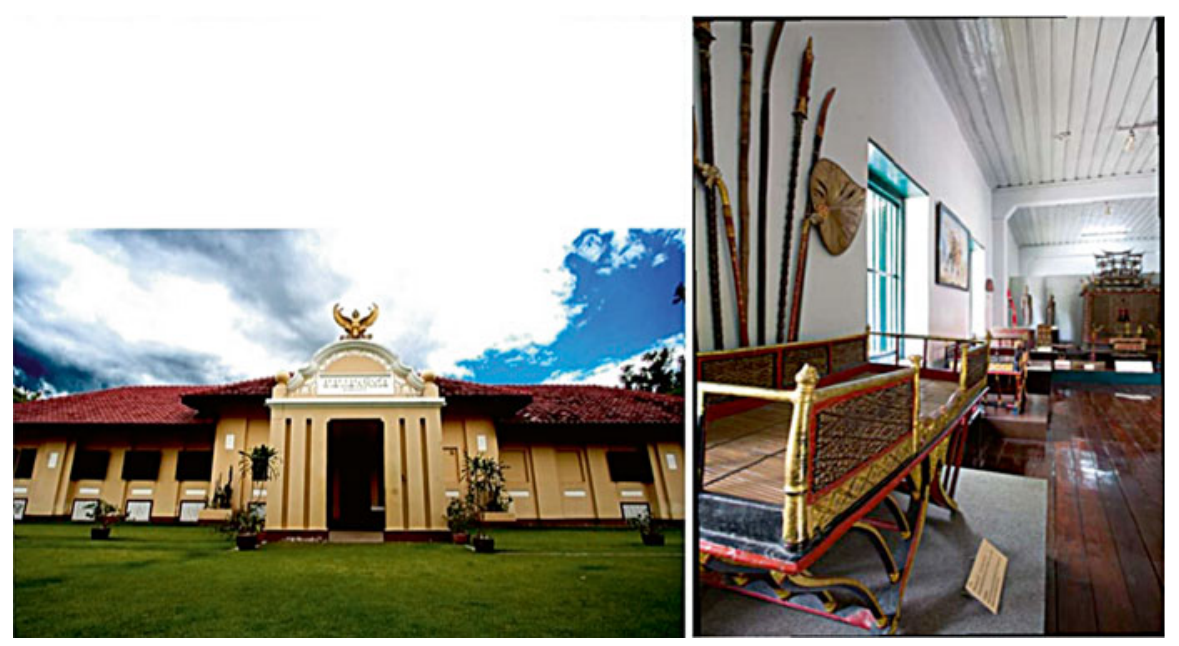

Fig. 7 Ubonratchathani National Museum

1. Museums are informal educational units.

2. A teacher has to lead a student to a museum.

For these reasons, national museums were expected to change their image and develop ways of presentation in the exhibition galleries, adding more educational services and facilities. A few national museums, of large scale, were able to approach the goal, but most of them could not depend on personnel and budget.

The 41 national museums can be divided into three levels or scales: large, medium, and small.

- Large-scale museums are mostly regional national museums: Chiang Mai National Museum, Ramkhamhaeng National Museum, Chaosamphraya National Museum, Somdet Phranarai National Museum, U Thong National Museum, Khonkaen National Museum, Phimai National Museum, Songkhla National Museum, and Nakhon si Thammarat National Museum. There are two national museums in the center: the National Gallery and Kanchanaphisek National Museum. The National Museum Bangkok is considered to be a special level.

- Medium-scale museums are mostly city museums: Ubonratchathani National Museum, Ratchaburi National Museum, Surin National Museum, Banchiang National Museum, Chandharakasem National Museum, Chumphorn National Museum, Suphanburi National Museum, and so on.

- Small-scale museums are all former monastery museums before transfer to becoming national museum units: Mahawerawong National Museum, Matchimawat National Museum, Inburi National Museum, Chainatmuni National Museum, and so on.

The lack of museum personnel is quite a big problem. Nowadays, there are approximately 90 curators working in the national museums. There are three, two, 
and one curator(s) for large, medium, and small scale respectively. Thai curators have to be museum manager, exhibitor, educator, and academic maker all at the same time, as well as sometimes conservator, without an academic degree in museum management, exhibition, and conservation. They have learnt by experience, through coaching, training, workshops, and studying by themselves. However, this is not always the case. A few curators "pass an exam," can run museum work, and approach the goal. Certainly, most curators aim to run their museum as head or director so as to save budget on academic research. That is to say, the Office of National Museums, Fine Arts Department, is nowadays lacking specialists in ancient objects and art objects including museology and museography.

Of course, the next problem is inadequate budget. The main part of the budget for the 41 national museums comes from the central government, through the Fine Arts Department, which is responsible for 26 divisions/offices concerned with preservation and promotion of the artistic and cultural heritage of the nation. In fact, museum operations definitely need a rather large budget for maintenance and modification. Many national museums have never changed their permanent exhibitions after formal opening to the public the first time, even the National Museum Bangkok. A few large national museums, such as Ramkhamhaeng National Museum, have been modified, but more than 15 years ago. Anyhow, there are at least five large national museums modified with new exhibitions, such as the U Thong National Museum, Songkhla National Museum, and Somdet Phranarai National Museum. The Nakhon Si Thammarat National Museum will be completed in 2020. Also, the Chiang Mai National Museum is now undergoing a modification project and planned to open in the next 2 years. It is unbelievable that the Chao Sam Phraya National Museum, in Ayutthaya Province, has never changed its exhibition since being opened to the public in 1963. Including the National Museum Bangkok, the project of renovation started in 2015. The duration of the project is 10 years, for archaeological excavation, reconstruction of monuments, and modification of permanent exhibitions, inside the old palace compound and inside two buildings, the Mahasurasinghanat and Praphat Phiphitthaphan buildings, where sculptural masterpieces of Thailand from the prehistoric period to the Ayutthaya period are housed.

However, more than ten national museums received budget supported by local government because of their uniqueness, such as the Phranakhon Khiri National Museum in Phetchaburi Province, Ban Chiang National Museum in Udonthani Province, and Kamphaengphet National Museum. Moreover, the Suphanburi National Museum is a good example of a museum receiving budget support from local government.

\section{Solutions and Development}

The solution to museum problems can be divided into two levels: the action level and the policy level. 

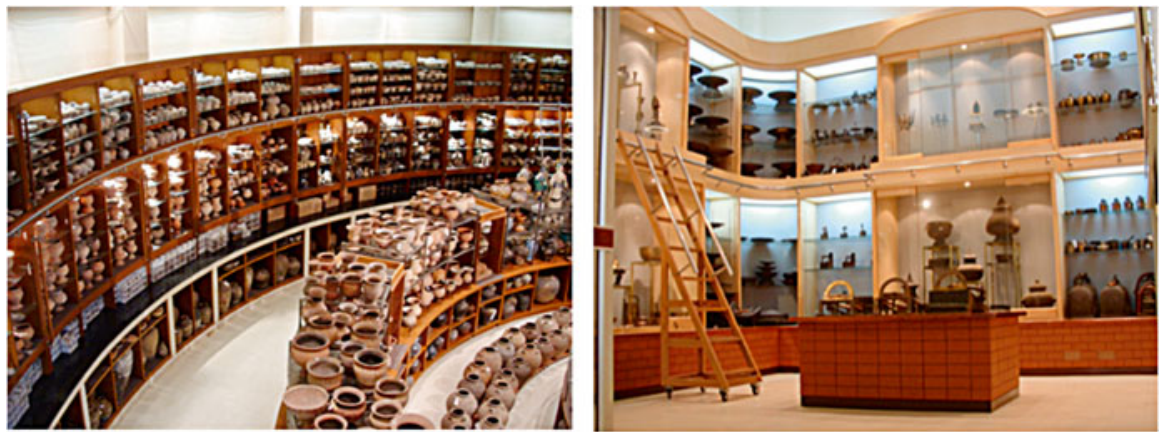

Fig. 8 Inside of the actual National Museum Storage in Pathumthani Province

Many national museums have attempted to change by themselves under limited conditions: contacting outsourcers, managing a youth museum guide, finding volunteers, creating museum souvenirs, and so on. Anyway, as mentioned before, this depends on each national museum's potentiality and readiness. It is very gratifying that many national museums, such as regional national museums and medium-scale museums like the Suphanburi National Museum, Ban Chiang National Museum, Roi-Et National Museum, Chiangsaen National Museum, and Surin National Museum have been established.

As for the policy level, this current time is very important for national museum management. To solve museum problems, the current Director General of the Fine Arts Department has announced his decision to reduce the number of national museums by transfer and combination. All of the small-scale national museums, formerly the monastery museums, have returned to being monastery museums, such as the Inburi National Museum in Singburi Province, Chainatmuni National Museum in Chainat Province, Matchimawat National Museum in Songkhla Province, Phra Phutthachinnarat National Museum in Phitsanulok Province, and Wat Benjamabophit National Museum in Bangkok.

To improve the image of national museums over the short term, there are three pilot projects. The first one is the establishment of seven national museum storage units to add a greater area for keeping huge numbers of ancient objects and art objects and also to develop storage management of a nearly universal standard. The first central storage unit, together with the Science Conservation Center in Pathumthani Province (Figs. 8 and 9), started this year, 2015, and there will be six more regional national museum storage units in Chiang Mai, Sukhothai, Khonkaen, Surin, Songkhla, and Nakhon Si Thammarat Provinces; of course, the storage buildings must be placed inside the national museum areas.

The second project is renovation of the National Museum Bangkok, following the master plan, for example, renovation of the old Palace Residences since the first Prince Successor and display inside each residence like its original function, and renovation of the permanent exhibition "Thai Civilization" inside these buildings. 

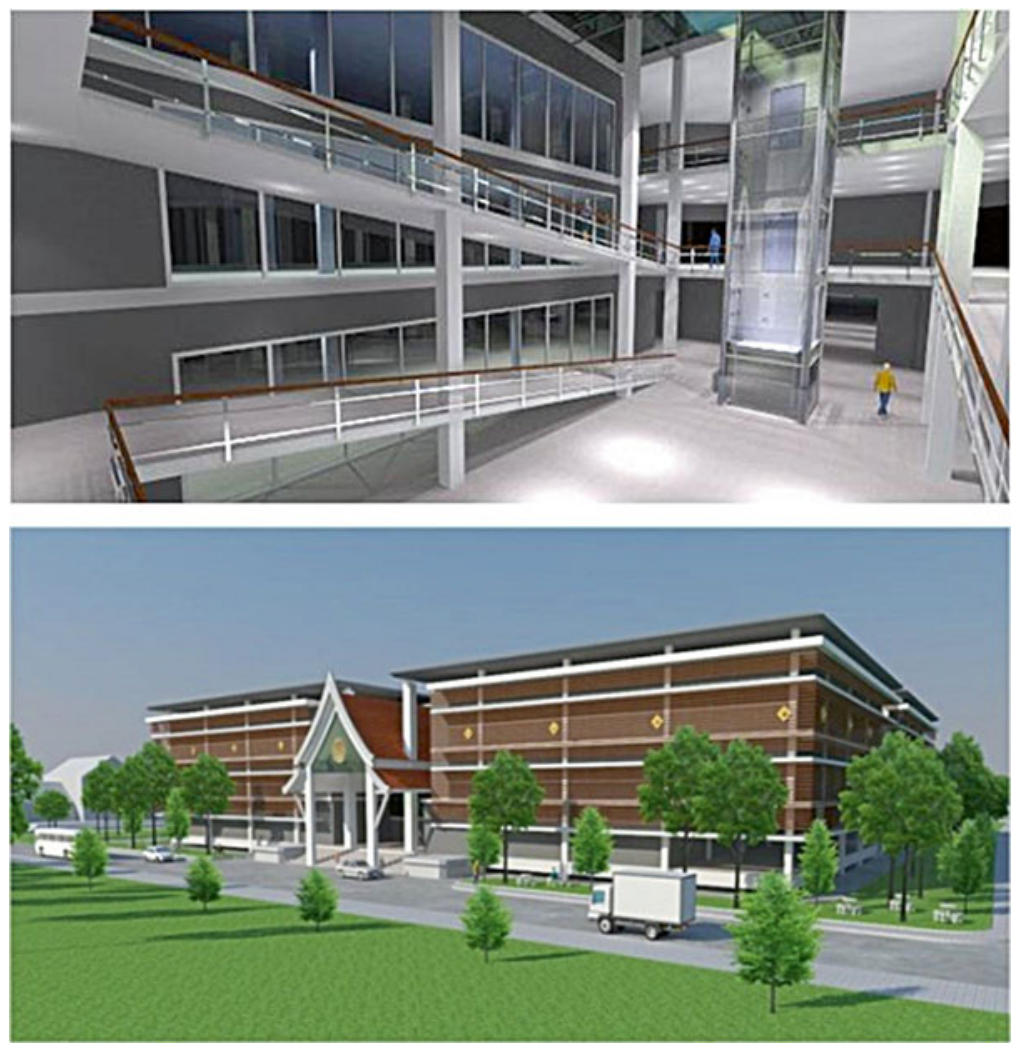

Fig. 9 A conceptual construction of a new central national museum's storage in Pathumthani Province

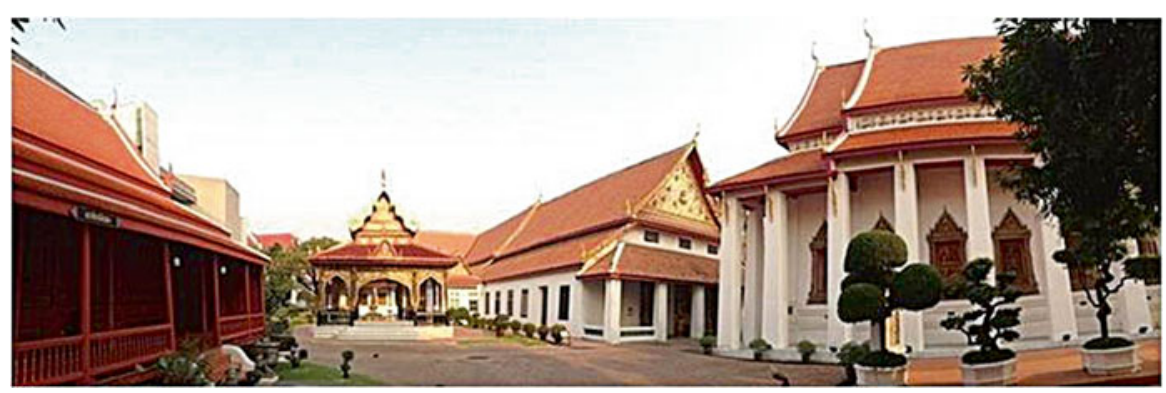

Fig. 10 National Museum Bangkok

Most of the collection comprises masterpieces that are very well known (Figs. 10 and 11).

And the last one is developing the Kanchanaphisek National Museum, the only ethnological national museum under the Fine Arts Department. Some national 


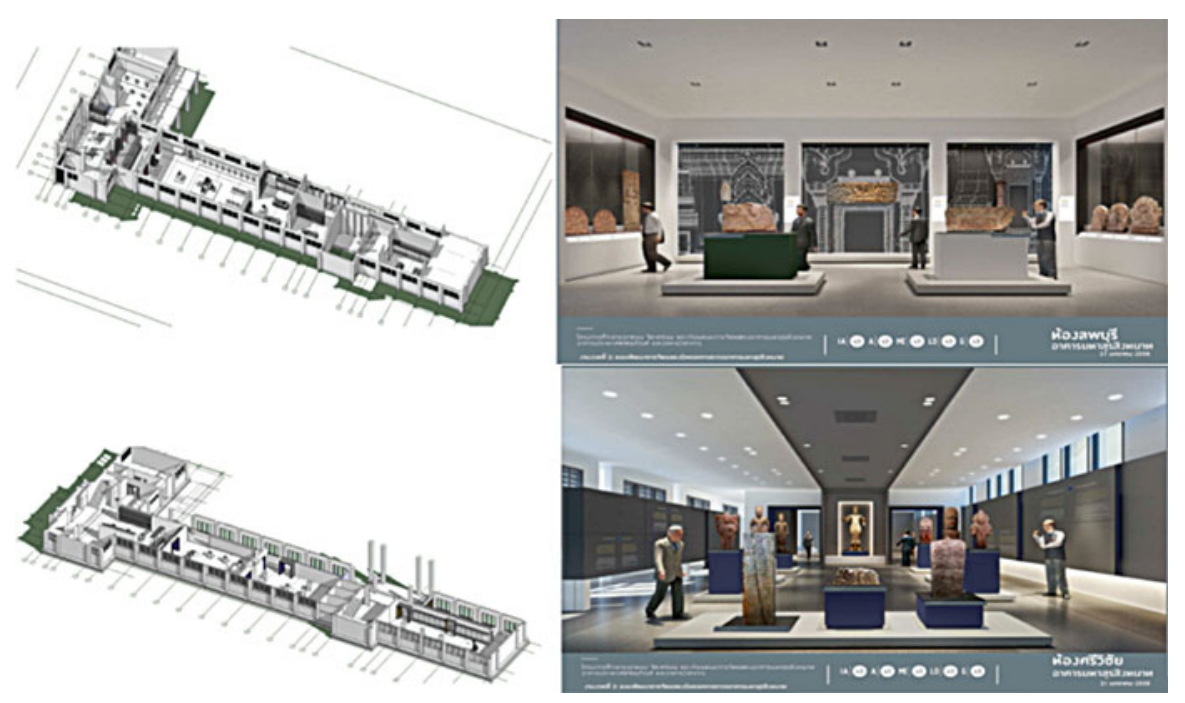

Fig. 11 Conceptual design of exhibition inside two buildings, National Museum Bangkok

museums in the provinces have ethnological sections in their gallery, with consideration given to ethnic people in the province and its surroundings. It is planned to intensively tell the story of all ethnic groups in Thailand at the Kanchanaphisek National Museum, under the titles "Window of Ethnology," "Way of Ethnographical Lives," and "Ethnographical Identity."

The museum consists of two buildings $\left(6,000 \mathrm{~m}^{2}\right)$ - central storage nowadays and an open area approx. of 79 rai $\left(126,400 \mathrm{~m}^{2}\right)$. The action plan for the development of the Kanchanaphisek National Museum, of which I am in charge, is into its fifth year: reconstruction of the old building; exhibition inside building no.1 (now storage for stone and large-size objects); setting up of an open-air "ethnographical architecture" exhibition; and renovation of building no. 2 (now storage for ethnographic and religious objects) and exhibition. It is planned to open the museum to the public after the exhibition in building no.1 and the open-air "ethnographical architecture" are finished.

\section{Conclusion}

In the world of museums everywhere, change is a very regular occurrence, especially changes to the administrative structure. The reduction in number of national museums is not a new matter. However, the changing of national museum management in Thailand during this time is not easy, but I eagerly anticipate these changes. 
Open Access This chapter is distributed under the terms of the Creative Commons AttributionNonCommercial 4.0 International License (http://creativecommons.org/licenses/by-nc/4.0/), which permits any noncommercial use, duplication, adaptation, distribution and reproduction in any medium or format, as long as you give appropriate credit to the original author(s) and the source, provide a link to the Creative Commons license and indicate if changes were made.

The images or other third party material in this chapter are included in the work's Creative Commons license, unless indicated otherwise in the credit line; if such material is not included in the work's Creative Commons license and the respective action is not permitted by statutory regulation, users will need to obtain permission from the license holder to duplicate, adapt or reproduce the material.

\section{References}

Fine Arts Department. 1974. Museums Management. Bangkok: The Religious Department Publishing. (Published in occasion of 100th Anniversary Celebrations of Museums in Thailand on 19 September 1974). (In Thai).

Fine Arts Department. 1993. King Rama VII and Museums Management in Thailand. Bangkok: Rungsilp Ltd. (Published in occasion of the 100th Anniversary of King Rama VII's Birthday). (In Thai).

Fine Arts Department. 1998. His Majesty the King of Thailand Kingdom and Museums Management. Bangkok: Graphic Format (Thailand), Ltd. (Published in occasion of The 50th Anniversary Celebrations of His Majesty's Accession To The Throne 1996). (In Thai)

Fine Arts Department. 2008. 149 Royal Museums. Bangkok: Union Ultra Violet Ltd. (Published in the occasion of The Sixtieth Anniversary Celebrations of King Bhumibol Adulyadej's Accession to the Throne 2006). (In Thai)

Office of National Museums, Fine Arts Department. 2006. The Directory of Museums in Thailand. Bangkok: Dok Bia Publishing. (In Thai). 
Part II

Museums in the Info-Age 


\title{
The Creation of a Registration and Information Database for Cultural Heritage in Mongolia
}

\author{
Galbadrakh Enkhbat
}

\begin{abstract}
Under the "National Project for Digitization of Cultural Heritage" started in 2005, a total of 42 organizations are involved in the registration and information state database of cultural heritage, using $\mathrm{RCH}$ (Registration of Cultural Heritage) software. So far, 45,645 names and 65,211 movable objects have been registered. For immovable historical and cultural properties, the registration is conducted using RICH (Registration of Immovable Cultural Heritage) software. So far, a total 32,124 historical and cultural immovable properties from 3,100 cultural sites in 15 provinces have been registered. Registration for ICH (Intangible Cultural Heritage) covers 329 soums (sub-provinces) and 9 districts, and 7,206 individuals identified as ICH bearers. In 2014, the "National Project for Digitization of Cultural Heritage-2" was approved, aiming to register and document cultural heritage, to take control of conservation and preservation of cultural heritage, to create a digital database for tangible and intangible cultural heritage, and to improve the system used for registration and information database of cultural heritage.
\end{abstract}

\section{Introduction}

By the consent of the People's Great Khural (the unicameral Parliament of Mongolia), the "Law on the Protection of Cultural Properties of the People's Republic of Mongolia" was adopted in 1970. In 1994, after several amendments, the law was adopted as the "Law on the Protection of Historical and Cultural Properties" by the State Great Khural and a new chapter related to the creation of a registration and information state database and its registration procedures was included.

According to the law, the registration and information state database will include research definitions, research reports, photographs, slides, audio and video recordings, and brief reports on restoration. The registration and information database is defined as having the purpose of classifying, conserving, and inheriting the heritage.

\footnotetext{
G. Enkhbat $(\bowtie)$

Center of Cultural Heritage, Sukhbaatar square -3, Cultural palace F- 2,

Ulaanbaatar -11, Mongolia

e-mail: enkhbat@monheritage.mn
} 
The database is also mandated to assist in the full recovery of cultural heritage elements when they are damaged, destroyed, or forgotten.

In 2001, several amendments were made to the 1994 "Law on the Protection of Historical and Cultural Properties" with articles added on the protection of intangible cultural heritage, and the law was renamed the "Protection Law for Cultural Heritage." According to the "Protection Law for Cultural Heritage," cultural heritage is classified as tangible and intangible. Tangible cultural heritage is classified as historical and cultural properties that are immovable and movable. Historical and cultural immovable heritage can be recognized as individual elements or as complexes.

On May 15th, 2014, the "Protection Law for Cultural Heritage" was amended by the State Great Khural.

\section{Registration Form}

In 1996, the first document "Registration form for historical and cultural properties of Mongolia" or form №1 was used to register museum objects, artifacts, and immovable properties in the database of historical and cultural properties.

Based on the revision of the "Protection Law for Cultural Heritage" in 2001, the "Registration form for historical and cultural properties of Mongolia" or form № 1 was amended as the "Registration form for Cultural Heritage of Mongolia" or form №2 by the 56th decision of Ministry of Education, Culture, and Science of Mongolia, in 2006.

However, the registration form did not allow for sufficient time to record enough information about museum objects and immovable properties. Therefore, in 2007, the Ministry of Education, Culture, and Science decreed in order №348 that the form "Registration of Historical and Cultural immovable properties" №1 be used instead. The order was approved and that form was used.

To assist in their required purpose of creating a database of intangible heritage and its bearers, in 2010, registration forms with specific questionnaires related to the registration of tangible heritage (historical and cultural movable and immovable properties) and of intangible heritage were adopted by 541st decision of the Ministry of Education, Culture and Science of Mongolia.

The "Registration form for historical and cultural movable heritage of Mongolia" gathers information using the following 34 questions, including: owner, possessor, address of location, condition, name of heritage, identification number, classification of heritage, decision, types or categories, relevant period, creator, creative skill, material and method, measurement, set, when collected and discovered, damage, decision for protection, purpose of use, common or uncommon status, origin, definition, brief history, restoration condition, reproduced or not, transfers or movement, relevant research, note of attachment, etc.

The "Registration form for historical and cultural immovable heritage of Mongolia" gathers information using 34 questions, including: province, Ulaanbaatar City, soum 
(sub-province), district, owner, possessor, identification number by registration and information database, name of heritage, classification of heritage, administration unit (heritage location), GPS, relevant period, protection condition, decision for protection, complex or not, date of discovery, measurements, protection condition, definition, brief history, relevant research, restoration condition, and note of attachment.

The "Registration form for intangible heritage and its bearers" gathers information according to 28 questions, including: province, Ulaanbaatar Province, soum, district, identification number by registration and information database, expression of intangible cultural heritage ( $\mathrm{ICH})$, information related with $\mathrm{ICH}$ bearer, information related to ICH elements, distribution of ICH elements and bearers, specific, safeguarding, etc.

After the revision of the registration forms, the guidelines and instructions were elaborated and enforced at every level of the registration and information database.

\section{Registration and Information Database}

The Center of Cultural Heritage created the registration and information database of cultural heritage. The center was established in 1988 as the Restoration Studio for Museum Objects. In 1996, in accordance with the 7th decision of the Government of Mongolia, the structure of the restoration studio was changed to the Center of Cultural Heritage and a new unit for the registration and information state database of cultural heritage was established.

The structure of the registration and information state database of cultural heritage is seen below (Fig. 1).

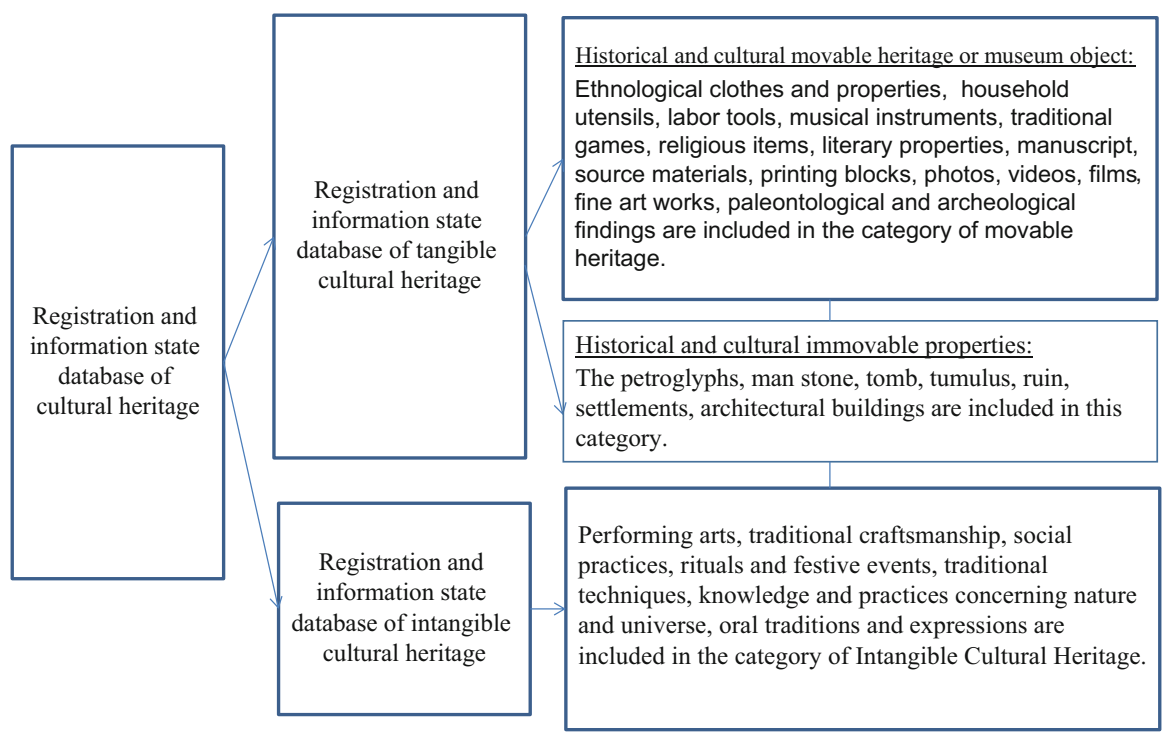

Fig. 1 Structure of the registration and information state database 
Cultural heritage registration database systems include:

- Organization registration database;

- Soum, district registration database;

- Province, capital city registration database;

- Unified state registration database.

Registration and information database components are:

- Paper-based registration and information: The object's general registration, classified registration, and research registration are guided by museum regulations. Registrations are completed using the approved forms for tangible and intangible heritage, and they include a heritage photo, research report, etc.

- Digital registration and information: Software "RCH", "Register", "RICH", digital version of the registration form, CD, DVD, hard disk, and audio and video recordings.

From 1996 to 2005, the registration and information state database received registrations from state and province museums in paper form, but this was not considered successful. The questionnaires did not gather enough information, and the state and province museums had poor internet access and a lack of staff members to complete the work.

The project "Automatic Measuring and Image Recording System for Historic and Cultural Heritage" was implemented by the Center through the support of Japanese Cultural Grant Aid in 1999-2000 (Fig. 2). Under the scope of this project, the Center was provided with computers and camera equipment for the documentation of museum objects, as well as some restoration equipment. Since then, photo documentation work has started in 21 provincial museums and the gathered data have been saved in the registration and information database. It was necessary to
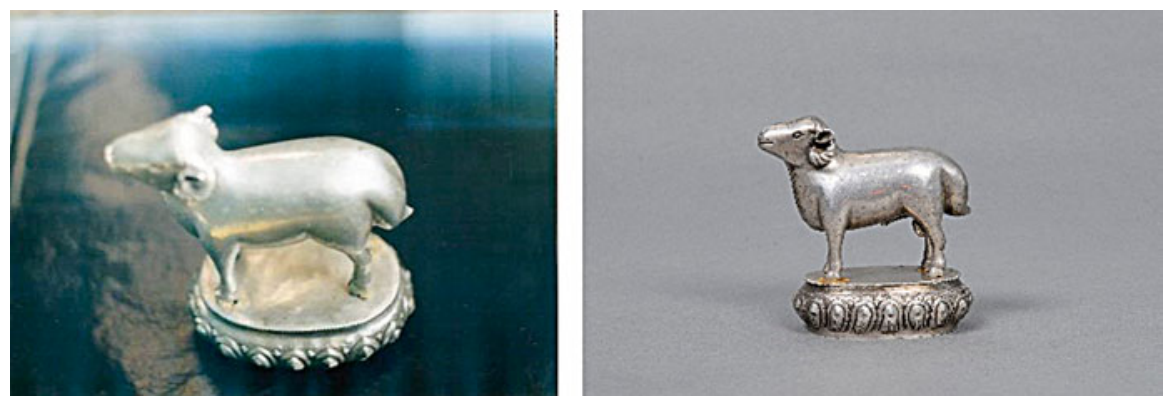

Fig. 2 Photo taken before (left) and after (right) implementation of the project "Automatic Measuring and Image Recording System for Historic and Cultural Heritage" 
provide museums with computer and camera equipment and to introduce new technology into the museums, because their equipment and facilities were previously inadequate for photo documentation of all the objects held in state museums.

Because of this, on December 7th, 2005, the Government of Mongolia in their 244th decision adopted the "National Project for Digitization of Cultural Heritage." The objectives of this project were to enhance the creation of the registration and information database of cultural heritage, to gather all data related to museum objects and historical and cultural properties, to improve the operation of primary registration and information database and systems of databases, and to create a unified state registration and information database.

Aiming to meet the objectives of the project, several measures were taken on human resources and technology. Based on the registration form "Registration form for historical and cultural movable heritage," the software "RCH: Registration of Cultural Heritage" 1.0 was created and installed in 38 museums in 21 provinces. In 2010, the software RCH was revised and RCH version 2.0 was created. These 38 state and provincial museums were provided with the following equipment:

- Computer and UPS (software RCH was installed)

- Printer

- Camera equipment for documentation of museum objects (professional digital camera, two lenses, umbrella, memory card, battery, and charger)

- Network sharing (State and province museums send their registrations to the state database through the internet.)

The new job position of "registration officer" was approved for museums in 2008, and several training workshops were organized for registration officers to provide them with a working knowledge of the $\mathrm{RCH}$ software and the process of registering museum objects.

In accordance with national legislation, museums send their registration to the soum, district, and province levels and to Ulaanbaatar City. The provinces and Ulaanbaatar City communicate with the unified state registration and information database, so there is no need for individual soums and districts to send data to the state.

Since using the software RCH, museum research workers and registration officers have sent details on around 800 objects to the state database, depending on the size of their museum's collection, but this work has been delayed.

The state inventories museum objects every 4 years, so information on all objects in state and province museums are gathered in the digital database with the use of the software register.

According to the 2014 revision to the law, the guidelines and instructions for the registration and information database have been amended, and it was decided that information will be saved equivalently in the registration and information databases at each level of soum, district, and province and Ulaanbaatar City.

Today, three software programs are being used for the digital database of tangible and intangible cultural heritage. 


\section{Database of Historical and Cultural Movable Heritage}

"RCH" or "Registration of Cultural Heritage" software was created as two types, based on one prototype. The software "RCH" or "Registration of Cultural Heritage" was installed in museums. Based on the software $\mathrm{RCH}$, the " $\mathrm{RCH}$ data processing software" received registration and information from 42 museums and processed the gathered information. Registrations done by the software $\mathrm{RCH} 2.0$ are received in the registration and information state database by the internet network and saved in the database.

As of today, a total of 42 organizations involved in the registration and information state database of cultural heritage and its network are sending their registrations in continuously (Fig. 3).

The software RCH is gathering data according to 55 questions in six parts (Center of Cultural Heritage, Culture and Art Committee. Ministry of Education, Culture and Science 2010: 2).

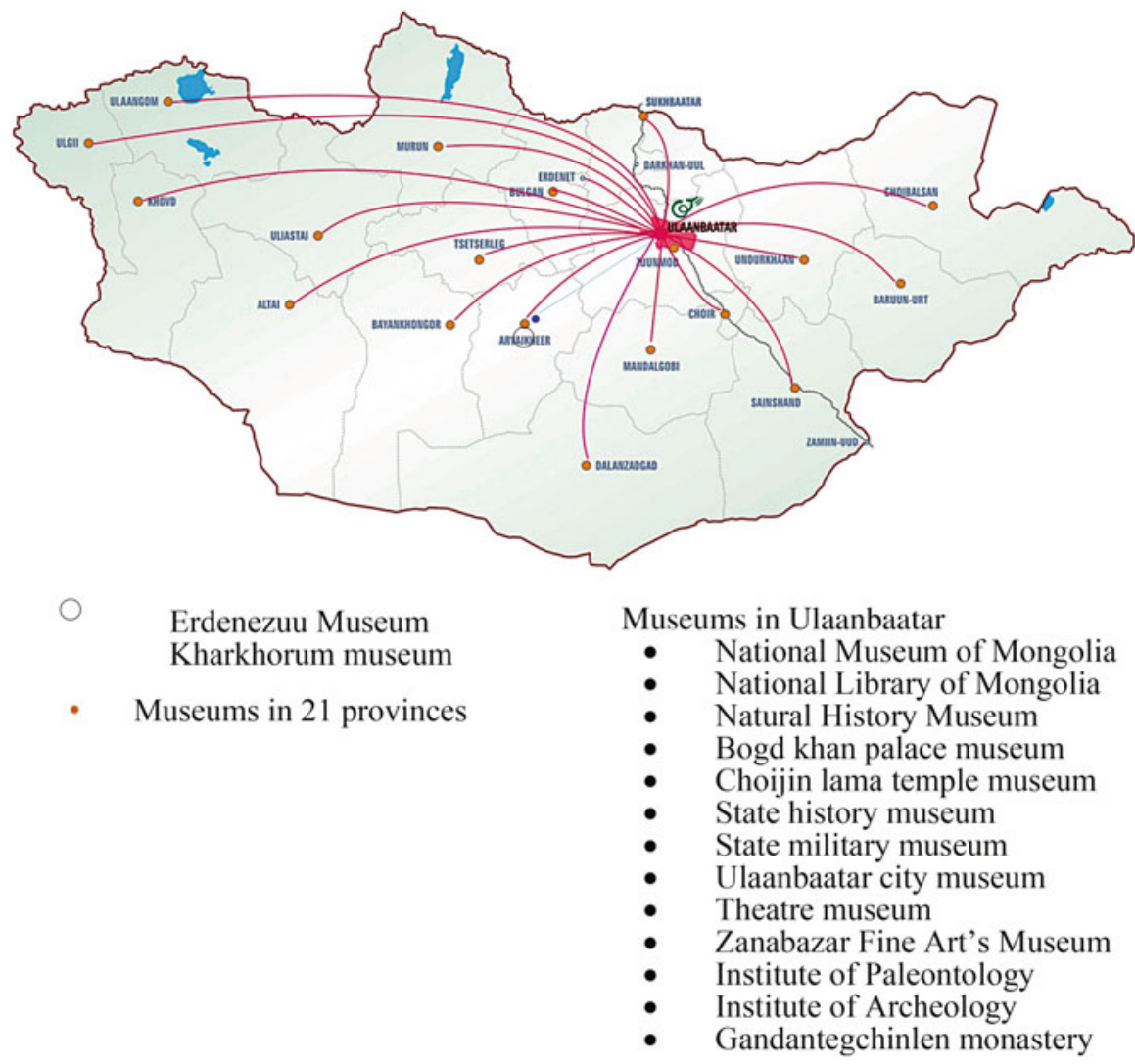

Fig. 3 Network built between Center of Cultural Heritage and state and provincial 42 museums 
(1) Art and artistic

1. Painting/every type of art painting, thangka painting, drawing, etc.

2. Sculpture/cast sculpture with all kinds of artistic value, relief and bas-relief, glass and ceramic art (ceramics), papier maché, etc./

3. Carving/crafted workmanship in all kinds of materials, such as wood and stone

(2) Historic

1. Artifacts related to historic persons or individuals/Choibalsan's watch, Yu. Tsedenbal's bag, D. Ravjaa's brush, etc.

2. Documents, audio and video recording/license, certificate, resolution, all kinds of tapes, films, recordings, CDs, etc.

3. Books and stationery/all kinds of texts, imprints, stationery, maps, etc.

(3) Ethnographic

1. Livestock transport/saddles, bridles, halters, strangling, lassoes, saddles, covers, feeding-bottles, collars, etc.

2. Hunting, farming/flint guns, leaden bullets, call-animal, plows, pans, sieves, etc.

3. Family housing, interior furniture/household items, furniture, dishes, buckets

(4) Religious

1. Deities/thangka paintings and forgotten nagtan $^{1}$ and gartan, ${ }^{2}$ printed or imprinted paintings, icons

2. Textile art/tapestries, embroidery, and laminated textiles

3. Casts/all kinds of religious large and small castings

(5) Archaeological

1. Stone tools/plates and billets, bread-like blades, etc.

2. Accessories and artifacts/earrings, necklaces, rings, belt ornaments, hair ornaments, animal casted figures, etc.

3. Husbandry artifacts/pottery and ceramic utensils, cups, plates, cereal bleached board stone and mortar/Stone and Bronze Age artifacts, etc.

(6) Natural

1. Mammals

2. Plants

3. Birds

\section{Specifics of the Software RCH}

- Detailed information on museum objects is gathered, and it is possible to aggregate, review, process, and print the registrations.

- Registrations can be linked with photographs of museum objects. 
- Information transferred by network can be classified as secure and kept in the data center.

- With the help of the software $\mathrm{RCH}$, we created a united network and provided state and provincial museums the following domain address: www.monheritage. $\mathrm{mn}$. With the use of this network and domain address, state and provincial museums are transferring their objects' registrations and information to the registration and information state database of cultural heritage.

- Every correction in an object's registration will be automatically downloaded and saved in the server.

As of today, 45,645 names and 65,211 objects have been registered in the software $\mathrm{RCH}$.

In August 2012, registration software was developed for the state inventorying of museum objects, and it was installed in 42 state and provincial museums and organizations. The registration software is based on the questions from the notebook "General registration for museum objects and artifacts," which allows the database to process data from different categories and periods and to adjust additional questions for each museum. After installing the initial version of the software, it was adjusted and improved 15 times, and each museum received these updates. According to the 140th order of the Ministry of Finance of Mongolia, the regulation "Fixing new value for historical and cultural heritage and museum objects" was approved. The registration software then added a way to save the value of each heritage. In the frame of state inventorying, 97,979 names and 229,976 objects in 42 state and provincial museums were registered in the software "Register" (Fig. 4).

\section{Database of Historical and Cultural Immovable Properties}

According to joint decision 299/324/111 by the Ministry of Finance, the Ministry of Education, Culture and Science, and the Ministry of Professional Inspection on September 27th of 2006, the inventorying work for "Historical and cultural immovable heritage, such as tombs, tumuli, petroglyphs, inscriptions, stone monuments, temples and monasteries, ruins of ancient cities, and historic stupa and ovoo" 3 was approved and is being implemented by the Center. As of 2015, a total 32,124 historical and cultural immovable properties from 3,100 cultural sites in 15 provinces have been registered (Fig. 5), and the information collected is kept in the provincial database and registration and information state database of cultural heritage.

According to the "Protection Law for Cultural Heritage" historical and cultural immovable properties were classified as 11 types regardless of their ownership. Based on the registration form, the software "RICH" or "Registration of Immovable Cultural Heritage" was created. The objective of this software is to create a state database of historical and cultural immovable properties and process the gathered data. The software "RICH" gathers data according to 35 questions in seven parts. These are as follows (Enkhbat et al. 2014: 103-131): 
Fig. 4 Classification of the objects registered
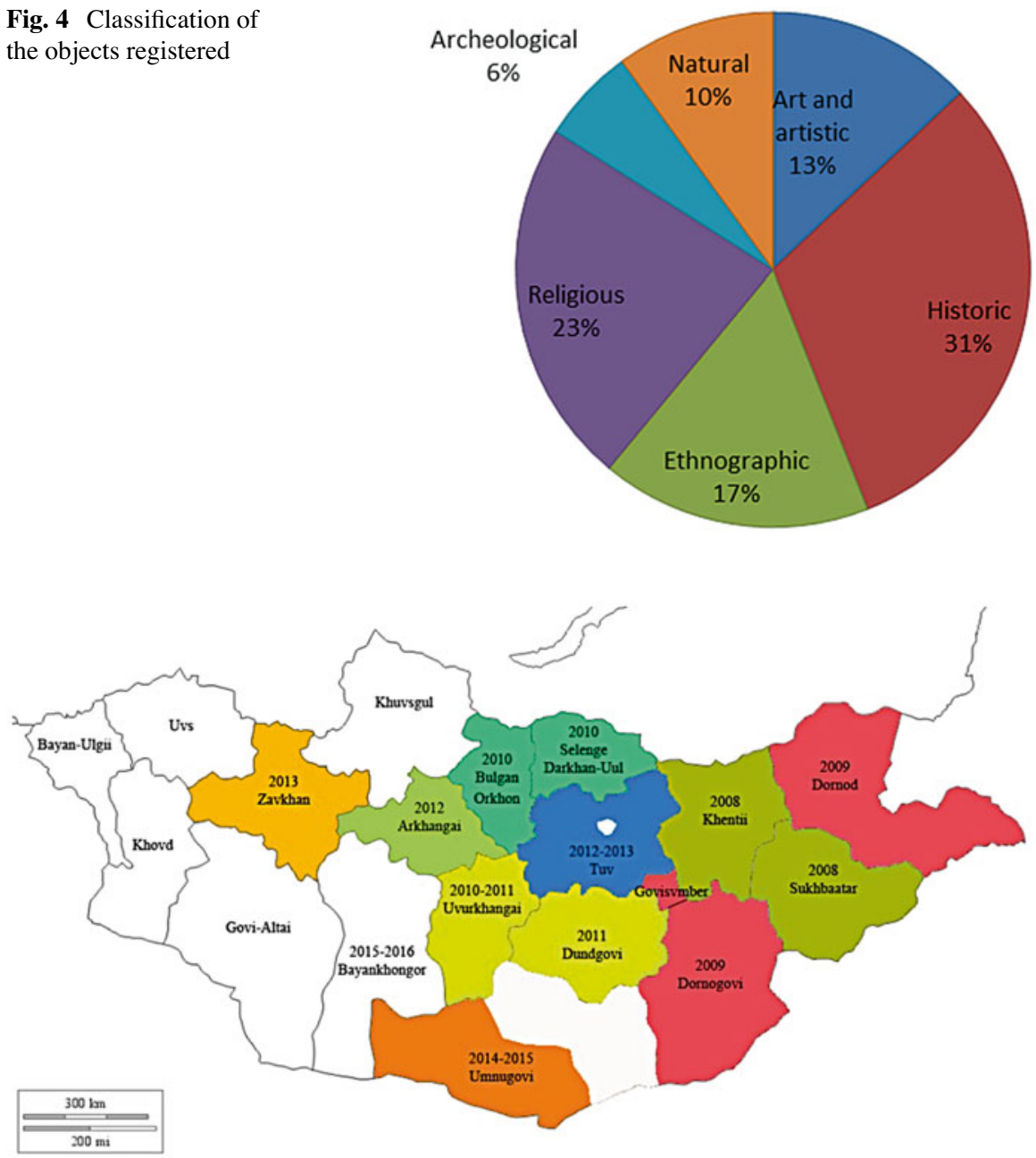

Fig. 5 Registration and inventorying of historical and cultural immovable properties (2008-2018)

\section{Classifications Used in the Software RICH}

1. Stone Age sites

2. Petroglyphs and other rock art

3. Tombs, tumulus, sacrificial structure

4. Architectural sites

5. Monuments

6. Places of mineral extraction and manufacturing

7. Natural sites 


\section{Questions of the Software RICH}

1. Places with findings of ancient flora

2. Places with findings of ancient fauna

3. Petrified wood

4. Fossils

5. Stone Age settlements and crafting places

6. Sites with stone tools

7. Ochre and ink petroglyphs

8. Carved petroglyphs

9. Symbols

10. Inscriptions

11. Deities paintings

12. Tombs and graves

13. Cave tombs

14. Tumuli

15. Sacrificial structures

16. Ovoo

17. Ruins of ancient cities and walls

18. Ruins of temples and monasteries

19. Monasteries and temples

20. Stupa

21. Architectural buildings

22. Fortresses

23. Drainage structures

24. Walls

25. Deer stones

26. Manstone monuments

27. Inscribed monuments

28. Animal-figured stones

29. Sealed monuments

30. Stone monuments

31. Inscribed commemoration monuments

32. Places used for mining

33. Places used for manufacturing of ceramics

34. Places used for agriculture

35. Zel stones or balbals ${ }^{4}$

\section{Specifics of the Software RICH}

- Every immovable property will be registered in the software RICH and numbered by the state registration and information database.

- It registers and collects the information related to historical and cultural immovable properties, and the collected data is then processed.

- It marks the GPS information of the immovable property on the map and includes a photo. 


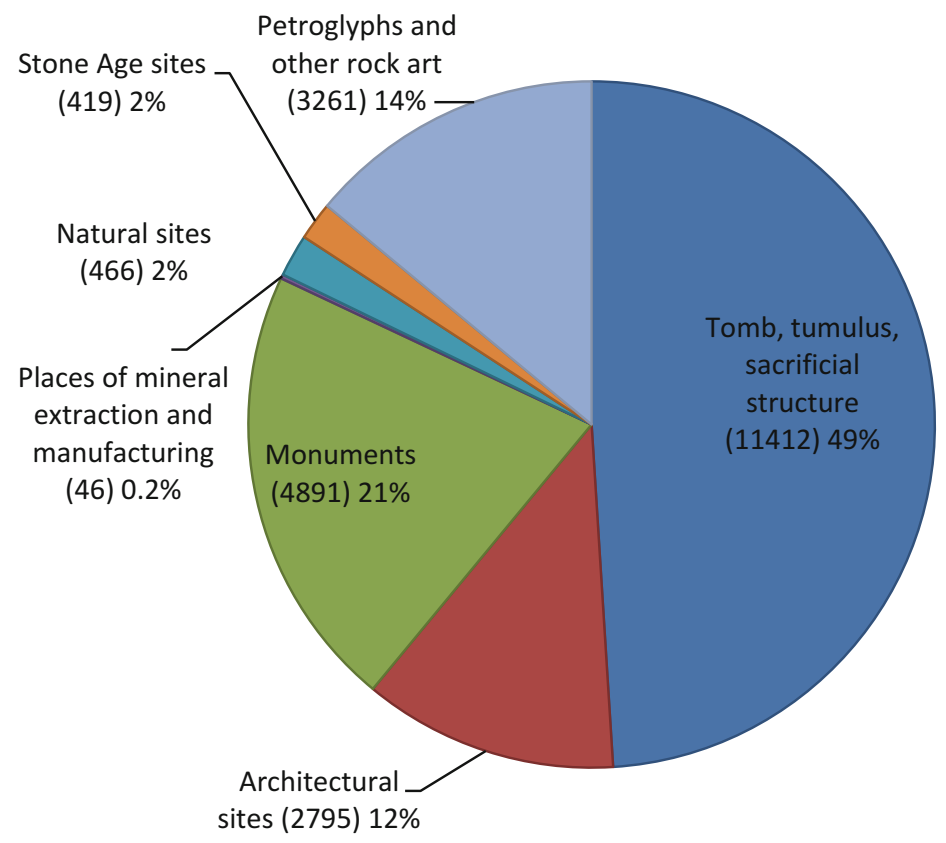

Fig. 6 Classification of the historical and cultural immovable properties registered

- Data from the registration and information state database can be searched and used in statistical analysis relating to the historical and cultural immovable properties in the territory of Mongolia.

As of 2015, 23,290 historical and cultural immovable properties in 2,031 cultural sites have been registered in the software RICH (Fig. 6).

\section{Registration and Information Database of Intangible Cultural Heritage}

Figure 7 shows the national registration and information system of intangible cultural heritage in Mongolia.

The Protection Division for ICH receives the registration and information of $\mathrm{ICH}$ and its bearers in the state database according to the form "Registration of ICH and its bearers" since 2010 (Table 1).

The rules for the registration and information database of $\mathrm{ICH}$ were approved and a manual was published. A training session and workshop was organized for local registration officers and cultural staff, aiming to improve the creation of the registration and information database and capacity building. 


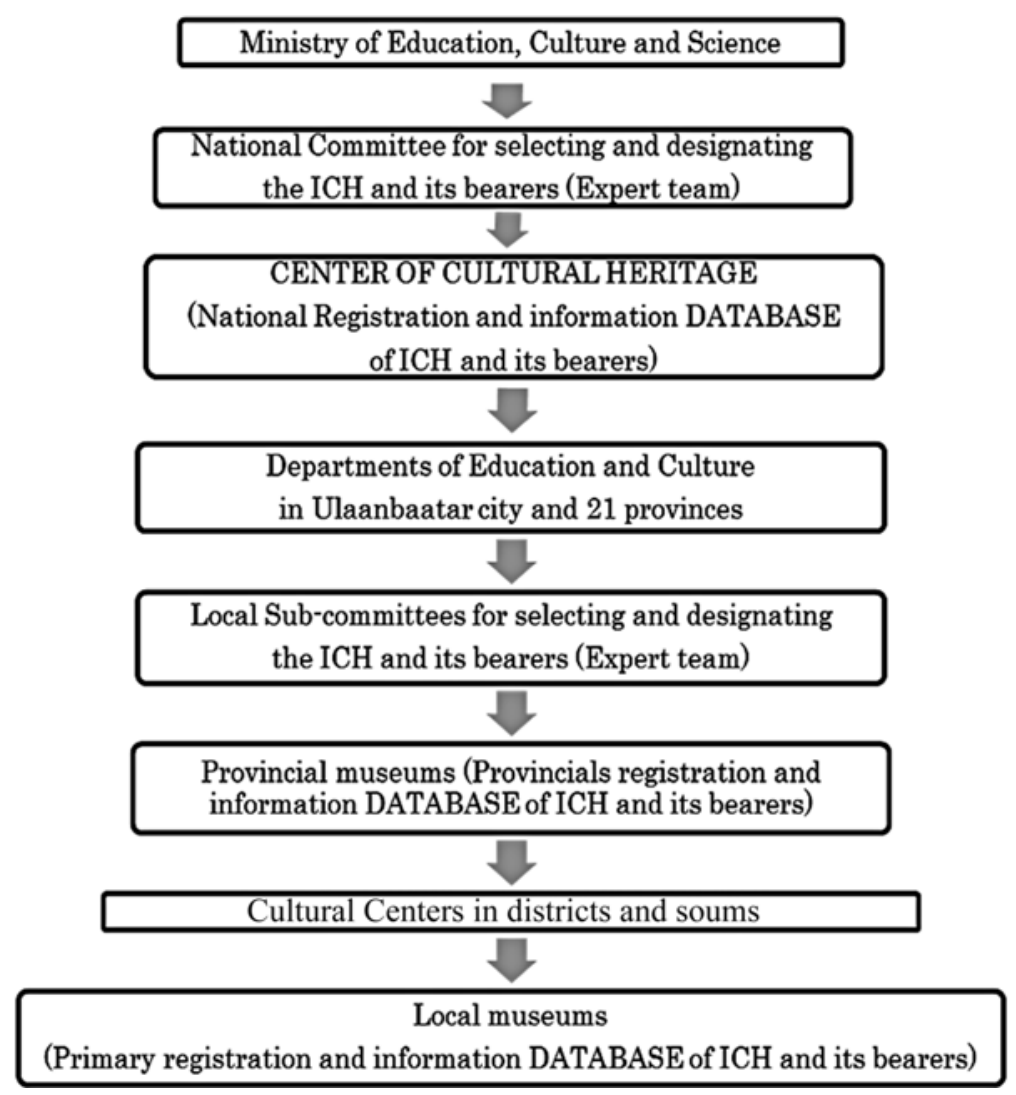

Fig. 7 Establishment of the National Registration and Information System of ICH in Mongolia

Table 1 ICH registration cycle

\begin{tabular}{|c|c|c|c|c|c|c|c|c|}
\hline \multicolumn{3}{|c|}{ Cycle I } & \multicolumn{3}{|c|}{ Cycle II } & \multicolumn{3}{|c|}{ Cycle III } \\
\hline $\begin{array}{l}\text { Month } \\
1\end{array}$ & $\begin{array}{l}\text { Month } \\
2\end{array}$ & $\begin{array}{l}\text { Month } \\
3\end{array}$ & $\begin{array}{l}\text { Month } \\
4\end{array}$ & $\begin{array}{l}\text { Month } \\
5\end{array}$ & $\begin{array}{l}\text { Month } \\
6\end{array}$ & $\begin{array}{l}\text { Month } \\
7\end{array}$ & Month 8 & Month 9 \\
\hline \multicolumn{3}{|c|}{$\begin{array}{l}\text { Acceptance of } \\
\text { applications from } \\
\text { communities, groups and } \\
\text { individuals at the local } \\
\text { Departments of } \\
\text { Education and Culture in } \\
\text { provinces and Cultural } \\
\text { Centers in soums }\end{array}$} & \multicolumn{2}{|c|}{$\begin{array}{l}\text { Evaluation and } \\
\text { Selection by } \\
\text { Provincial } \\
\text { "Sub- } \\
\text { committees for } \\
\text { Selecting and } \\
\text { Designating } \\
\text { ICH and its } \\
\text { Bearers" }\end{array}$} & \multicolumn{2}{|c|}{$\begin{array}{l}\text { Elaboration and } \\
\text { consolidation by } \\
\text { the Center of } \\
\text { Cultural } \\
\text { Heritage under } \\
\text { the Ministry of } \\
\text { Education, } \\
\text { Culture, and } \\
\text { Science }\end{array}$} & $\begin{array}{l}\text { Selection and } \\
\text { designation } \\
\text { by "National } \\
\text { Committee } \\
\text { for Selecting } \\
\text { and } \\
\text { Designating } \\
\text { ICH and its } \\
\text { Bearers" }\end{array}$ & $\begin{array}{l}\text { Approval by } \\
\text { the Ministry } \\
\text { of Culture, } \\
\text { Sports and } \\
\text { Tourism }\end{array}$ \\
\hline
\end{tabular}




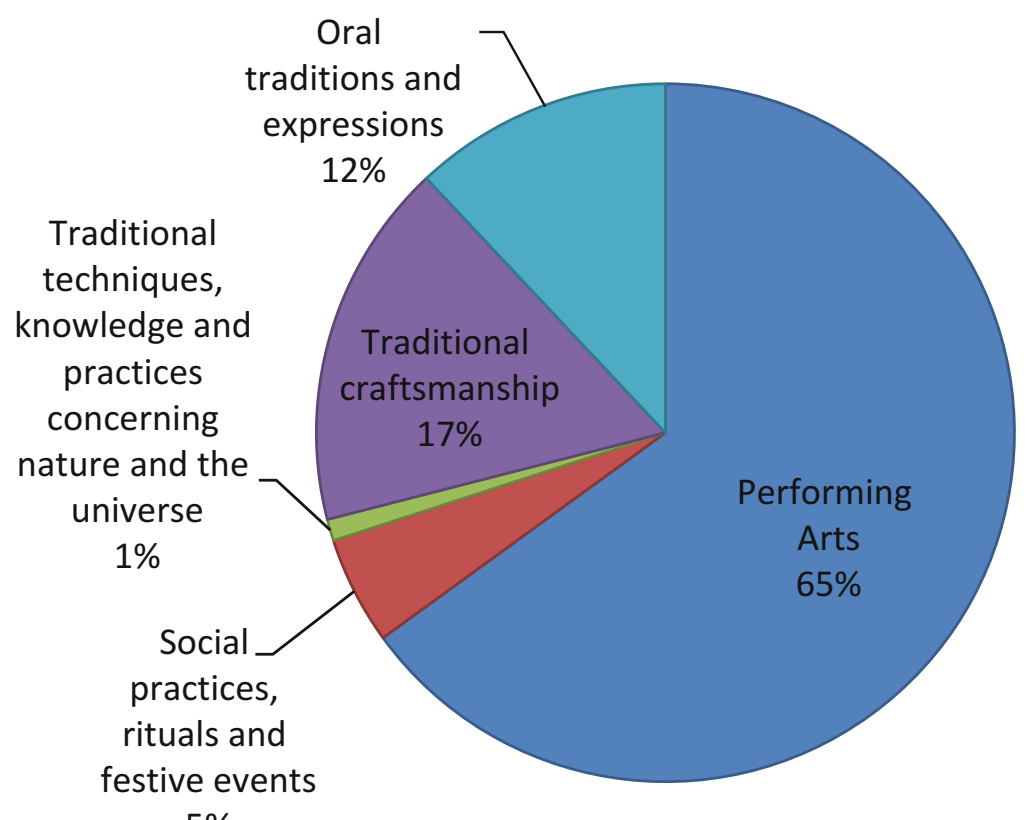

$5 \%$

Fig. 8 Registration census of ICH bearers by domain (2013): 7206 ICH bearers by five classifications

Registration work of ICH covered 329 soums and 9 districts and increased the number of individuals identified as ICH bearers to 7,206. The results of the registration census are a valuable asset gathered as a source to further elaborate the shortand long-term objectives, policies, and programs for safeguarding and transmitting ICH (Figs. 8 and 9) (Yundenbat and Tuul 2012: 90).

Since 2013, registration and information of ICH has been saved in the digital database. It is a priority for the information on $\mathrm{ICH}$ bearers to be saved in the digital database. As of today, $568 \mathrm{ICH}$ bearers' information is saved in the digital database. In the future, intangible cultural heritage elements will be saved in this database.

\section{Problems in the Creation of a Digital Registration and Information Database of Cultural Heritage}

Problems related to the creation of database of cultural heritage can be summarized as follows:

\section{Problems Related to the Software RCH and Register}

- The budget for registration and documentation of museum objects is inadequate. 


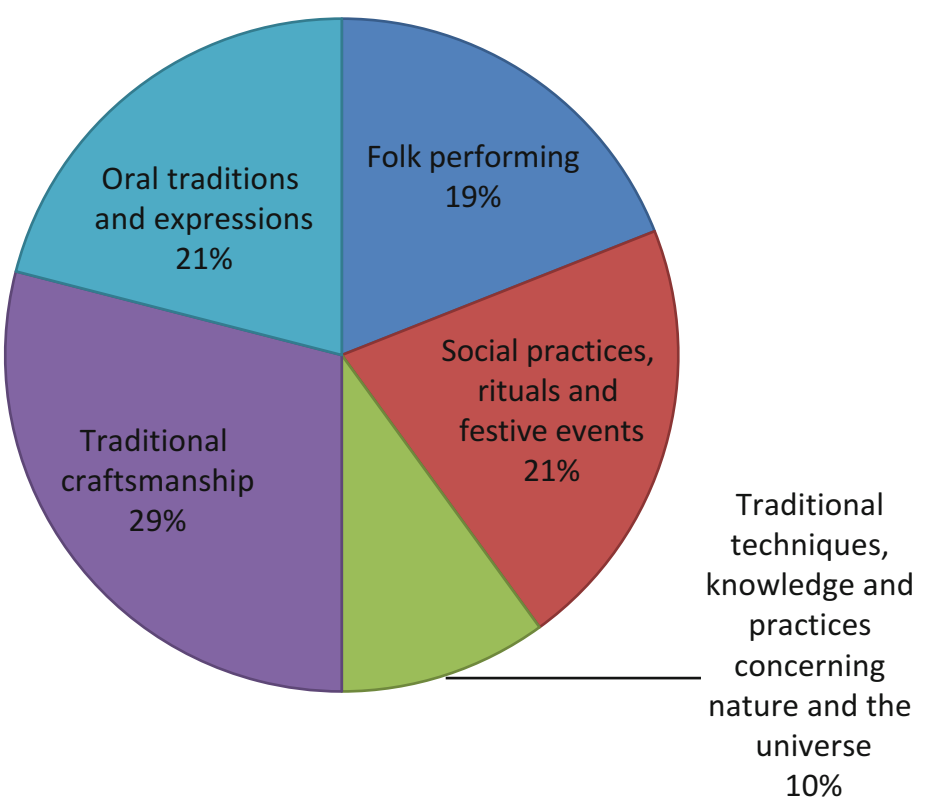

Fig. 9 Registration census of ICH elements by domain (2013): 104 ICH elements by five classifications

- Equipment and human resources for registration of museum objects are inadequate.

- Services of the registration and information database and relevant registration officers have just been established.

- There is a lack of experience in computer and software use, leading to computer viruses.

- There are occasional losses of data, system failures, etc.

\section{Problems Related to the Software RICH}

- Delayed information uploading.

- There is a limited data range because data are uploaded only by the Center of Cultural Heritage, which are gathered during the research and inventorying of historical and cultural immovable properties.

- Only some of the early paper-based registration forms in the registration and information database have been uploaded.

- Other research institutes did not participate in using this software.

- It is necessary to encourage other research institutes to participate in using the software and gathering the data.

- All data related to historical and cultural immovable properties in the registration and information state database should be saved in the software RICH. 


\section{Problems Related to the Registration of ICH Bearers}

- Due to difficulties in documentation equipment, there are some problems in the everyday activities of the division and the creation of a database.

- However, a registration of ICH bearers started in the provinces and Ulaanbaatar City in 2010. Registration is not adequately performed in accordance with the registration form due to inadequate methods, equipment, and finances.

\section{New Technologies Used in the Digital Database}

\subsection{Three-Dimensional Documentation}

Three-dimensional documentation for movable and immovable heritage started at the Center in 2008. Since then, several documentation works have been done in collaboration with the National Research Institute for Cultural Properties (NRICP), Tokyo, and Doshisha University and the processed data of 3D documentation have been saved in the registration and information state database of cultural heritage (Fig. 10).

\subsection{Improvement of Diagnostic Equipment of the Center of Cultural Heritage}

Aiming to make digital documentation for cultural heritage, historical and cultural immovable properties, and intangible heritage and to analyze the material composition of museum objects and archeological artifacts, the Center initiated the project

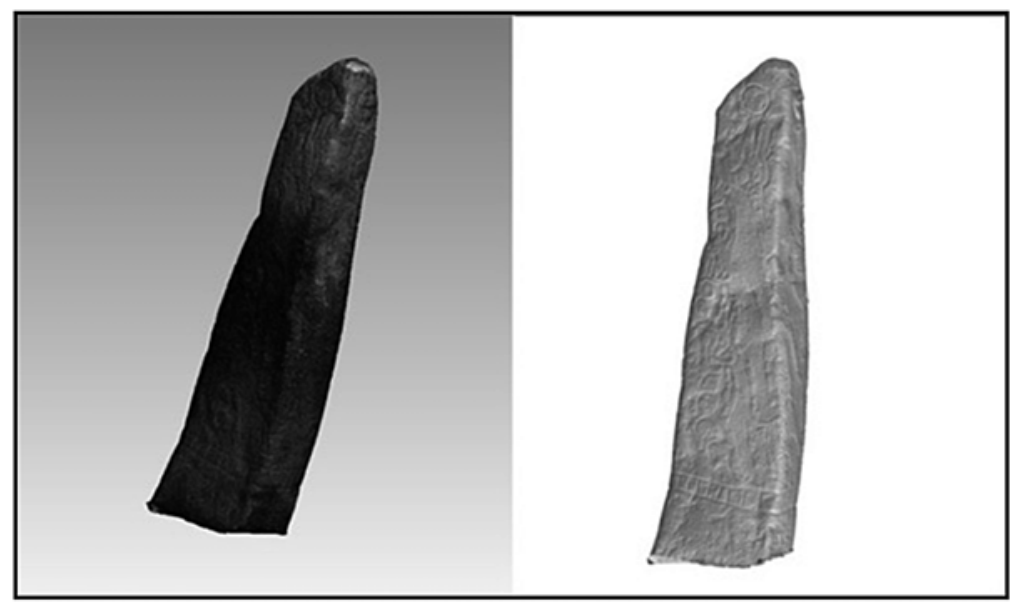

Fig. 10 Deer stones of Dund Jargalantyn am in Omnodelger soum of Khentii Province 


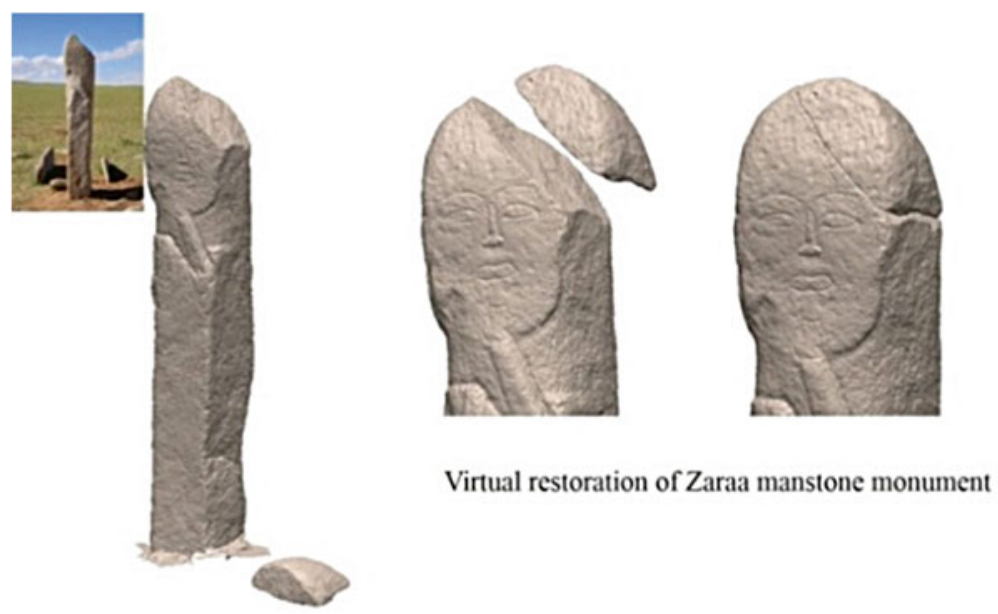

Fig. 11 Visual restoration of Zaraa manstone monument

"Improvement of Diagnostic Equipment of the Center of Cultural Heritage" in 2009 and it was implemented in 2013 through Japanese Cultural Grant Aid. Under the scope of the project, the Center was provided with a portable 3D digitizer (Vivid 9i). Three-dimensional documentation of museum objects and historical and cultural immovable properties is being undertaken with the use of Vivid 9i and the collected data are saved in the digital database. Based on gathered data from 3D measurements, virtual restoration works have been done for some immovable properties (Fig. 11).

\subsection{National Project for Digitization of Cultural Heritage-2}

The implementation of the "National Project for Digitization of Cultural Heritage" (2006-2008) basically covered museums; it was not dedicated to and did not cover the creation of a registration and information database for historical and cultural heritage and intangible cultural heritage through the state.

For this reason, the Government of Mongolia has approved the "National Project for Digitization of Cultural Heritage-2" by its 215th decision in 2014, aiming to register and document cultural heritage, to take control of conservation and preservation of cultural heritage, to create a digital database for tangible and intangible cultural heritage, and to improve the system used in the registration and information database of cultural heritage.

The objectives of the project is to create a registration and information database of cultural heritage at the level of soum, province, and Ulaanbaatar City and related to this, to provide and decide necessary matters, such as human resources, budget, and equipment. Every soum and province will register and document the tangible 


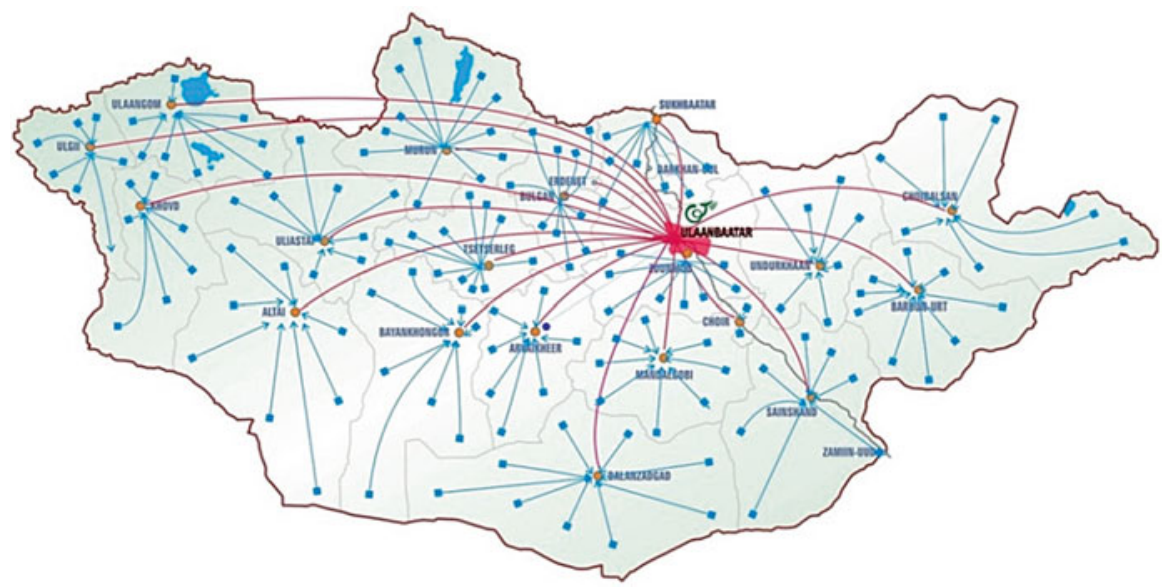

Fig. 12 Registration and information database of cultural heritage at the level of soum, province, and Ulaanbaatar City under the "National Project for Digitization of Cultural Heritage-2"

and intangible cultural heritage in their territory and create a registration and information database using the gathered data (Fig. 12). It will serve to improve the registration and documentation of tangible and intangible cultural heritage, as well as to create a registration and information database;

For museum objects and artifacts, it will improve the activity of the registration and information database in museums and research organizations; it will activate the research and study of objects and to use the research results in the registration; and it will improve the registration and documentation of museum objects and responsibility.

For historical and cultural immovable properties, it will make cadastral confirmation of historical and cultural immovable property, selected to be in the protection of "State," "Province," or "Ulaanbaatar City" by the decision of the Government of Mongolia; it can number the historical and cultural immovable property registered in the registration and information database; and it serves to organize registration and documentation work for historical and cultural immovable properties through the territory of soum and province.

For intangible cultural heritage, it will improve the registration system of intangible cultural heritage and create a registration and information database of intangible cultural heritage; it helps to increase the number of ICH elements in the list of Need of Urgent Safeguarding and Representative List of Intangible Cultural Heritage.

\section{Notes}

1. Thangka paintings on black background are called nagtan.

2. Thangka paintings on white background are called gartan.

3. Ovoo is a sacred cairn found in Mongolian shamanic religious traditions, usually made from rocks or wood. Ovoo is often made at the top of mountains and in high places. 
4. Zel stone or balbal is an ancient worshiping stone without description (plain stone) which situated next to the burial. This kind of stone is one part of the burial complex that continues a long distance of about $1 \mathrm{~km}$ with many separated pieces (defends its burials type). Many of them are ordered and especially directed to the south east direction which means direction of sunrise.

Open Access This chapter is distributed under the terms of the Creative Commons AttributionNonCommercial 4.0 International License (http://creativecommons.org/licenses/by-nc/4.0/), which permits any noncommercial use, duplication, adaptation, distribution and reproduction in any medium or format, as long as you give appropriate credit to the original author(s) and the source, provide a link to the Creative Commons license and indicate if changes were made.

The images or other third party material in this chapter are included in the work's Creative Commons license, unless indicated otherwise in the credit line; if such material is not included in the work's Creative Commons license and the respective action is not permitted by statutory regulation, users will need to obtain permission from the license holder to duplicate, adapt or reproduce the material.

\section{References}

Center of Cultural Heritage, Culture and Art Committee. Ministry of Education, Culture and Science. 2010. Muzein burtgel-medeelliin sanch nart zoriulsan "Soyolyn uviin burtgel medeelliin sang burduulekh ni” seminar. Ulaanbaatar: Admon Printing Co. Ltd. (In Mongolian).

Enkhbat, G., B. Altansukh, G. Ankhsanaa, and T. Erdenetsogt. 2014. Tuukh soyolyn ul hudlukh dursgalyn uzleg, toollogyn burtgeliin RICH programyn garyn awlaga. Ministry of Education, Culture and Science, Center of Cultural Heritage. Ulaanbaatar: Admon Printing Co.Ltd. (In Mongolian).

Yundenbat, C., and G. Tuul. 2012. Soyolyn biyet bus uwiig burtgen barimtjuulakh, burtgel medeelliin san burduulekh arga zui. Ministry of Education, Culture and Science, Center of Cultural Heritage. Ulaanbaatar: Soyombo Printing Co.Ltd. (In Mongolian). 


\title{
Rewiring Museum Information: Mobile and Cloud
}

\author{
Atsushi Nobayashi
}

\begin{abstract}
At the National Museum of Ethnology, Japan (Minpaku), ImageFinder was designed to connect different kinds of information on an object through a new digital device: People search information not by using text but images of the objects instead. Another instrument called MAP (Minpaku Anthropological Phototheque) shows pictures taken by Minpaku staff in their fieldwork. These examples show that rapid progress in the design of digital devices and growth of the Internet community have changed the way to offer information on exhibitions and the museum itself. By connecting the information, visitors and users might find additional information or produce new contents and feed them back to the museum. As Minpaku collects materials concerned with human culture, we can show the existence of material culture in each period all over the world. Objects and information related to them would be our inheritance of intelligence on this planet.
\end{abstract}

\section{Introduction}

The aim of this paper is to introduce new methods of supplying information on the exhibits in the National Museum of Ethnology, Osaka, Japan (NME, Minpaku) and discuss their significance for the museum. These methods can show fundamental information on the objects displayed or stored in the museum and the results, new findings, and special knowledge of academic studies. Visitors to the museum can use them when they see the exhibits.

I will introduce two instruments: one is called ImageFinder and the other is called MAP (Minpaku Anthropological Phototheque). ImageFinder was developed as one of the media in the information zone in Minpaku. ImageFinder can contribute to making visitors to Minpaku aware of the existence of various kinds of information on the objects. MAP is used to supply different kinds of information on the exhibits from ImageFinder. We have a MAP for the regional cultures of China and it shows pictures that have been taken by Minpaku staff members. Not all of pictures

\footnotetext{
A. Nobayashi $(\bowtie)$

National Museum of Ethnology, Senri Expo Park, Suita, Osaka 565-8511, Japan

e-mail: nova@idc.minpaku.ac.jp 
are directly concerned with the objects in the exhibition, but they often provide background information relevant to exhibition themes.

I show how ImageFinder and MAP can supply information and then discuss the significance of supplying information in the museum. I especially focus on mobility and collectivity of information and discuss the possibility of these methods being used outside the museum.

\section{The Limit of Transmitting Information to Visitors in the Museum}

We can share various kinds of information in Minpaku and classify them as follows: (1) information on how to use the museum, (2) information on exhibits in the museum, and (3) information on the academic research of museum staff.

The information on admission fees, open days, and access map to the museum or plan of the exhibition hall are included in the first category. We have to provide them inside and outside the museum. The second information type is complicated. The name of the object, the area or country where it was collected, and the ethnic group or population that owned or used it belong to the second type of information in Minpaku. At the same time, the context in which it was used or the significance of the object in society also belong to the second type. They might, however, be treated differently when offered to visitors. The name, area, and ethnic group's name might be indicated in a caption to the objects in the exhibits. The object not only has fundamental information such as the name or original owner but also its cultural and historical background. They have been studied by academic staff and accumulated in the museum. There is a large volume of them and they cannot be explained only by the captions or panels that are usually set in the museum. They can be explained by other methods including electric devices or lectures by the museum staff. We can use different methods or ways to supply information on the objects to the museum visitors according to nature of the information (Nobayashi 2014a).

We also have to understand the nature of the media when we use them to supply information in the museum. We should recognize different media according to the contents of the information and the subjects to which we offer the information. For example, it is necessary to consider what words we should use in a pamphlet, the utilization of kanji (Chinese characters used in Japanese transcription), the size of the letters, the language according to the target age, nationality, and so on.

We cannot supply so much information in the exhibitions. The museum has limited space, available media, and number of staff who can support visitors. We have to select information to offer it effectively and efficiently to the visitors to the museum. Visitors might also see the museum exhibition within a limited time. If the museum tries to offer too much information on the exhibits, the visitors will be unable to digest most of it during their visit to the museum. 
When we understand that the information we can offer to the visitors is limited, we become aware of the strict conditions of offering information. Insufficient information about an object or exhibit might give visitors not only insufficient understanding but also wrong understanding. It is a major purpose of Minpaku to have visitors deepen their understanding of the history and the culture of human society with the exhibits. This cannot be achieved without enough information about human culture and society from the results of academic studies.

\section{Rewiring Various Information in the Museum: ImageFinder}

We were able to understand that we need to offer information at the museum to visitors for advancing their understanding. On the other hand, we know that information is distributed around the museum and some of it might not be in an easily accessible place. Some contents might be separated and visitors do not know that they are concerned with each other. Minpaku's exhibits are constructed with academic research and objects have been collected by the academic staff. They have also published books, articles, and essays as a result of their research and study. They have also accumulated at first hand materials including field notes, movies, pictures, and official documents while collecting materials. In fact, objects in Minpaku's exhibitions are rich in information concerning human culture and academic research. However, visitors do not necessarily have enough time to access them. The museum encourages its visitors to improve their knowledge or ideas by offering an appropriate means to provide information. It is most important for both visitors and the museum to have the chance and space to know the existence of various information relevant to the objects. We have to start sharing the information together.

We developed a new digital device offering information on the exhibits in Minpaku called ImageFinder under such conditions. It was designed to connect different kinds of information on an object through a digital device. The author engaged in developing it with the staff members of Minpaku, IT developers, and researchers. When we started the project, I showed a concept of the scheme to connect the existing contents in Minpaku (Fig. 1). We had used many kinds of media that offered information to the visitors to Minpaku but they were all independent.

We set the main purpose of the project as developing a means to show the connection of various information. We tried to make a new device that could wire the various information to the objects and show the connection and, as a result, have the users recognize the existence of information that is dispersed and not connected directly with the objects in the museum.

This system seems to work like a link collective site. It shows URL and users can move to the URL resource. What we tried to develop was different from such Internet linkage in the way of offering information. One reason is that we did not 


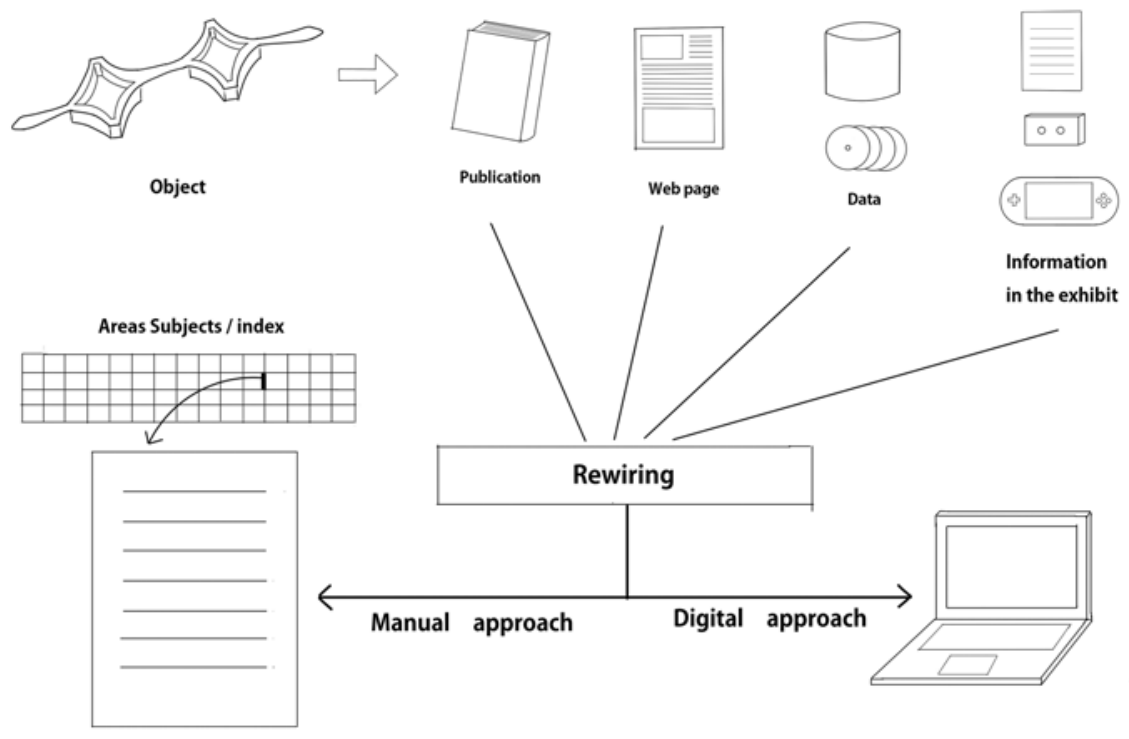

Fig. 1 A basic concept of the ImagFinder which the author offered at first

necessarily have all digital data of the information. It is sometimes difficult to make digital contents so that copyright is protected. We could not install all data in the same device. The other reason, what is more important, was that the new device was expected to encourage the visitors to search the information by themselves. To explore is the fundamental way of academic research. We expected the visitors to do autonomous activities (Fig. 2). We tackled the other important aspect in developing the device: a searching style without words. When we see an object for the first time and are interested in it, we try to collect information. We do not usually know the name, function, or its social context. We hoped that visitors would go through the same process as we did in our fieldwork. We therefore considered a way for people to search information not by using text but images of the objects instead. This might be an opposite direction for searching information in modern society where text searching is very popular for people using the Internet.

\section{The Possibility of Big Data: MAP (Minpaku Anthropological Phototheque)}

I also participated in another project to develop another digital device that could supply information on the exhibits. It was named Minpaku Anthropological Phototheque (MAP) and used in the exhibition "Regional Cultures of China" (Nobayashi 2014b). It showed pictures that were taken by Minpaku staff in their fieldwork. The picture itself is a useful medium in the museum. It shows the process 


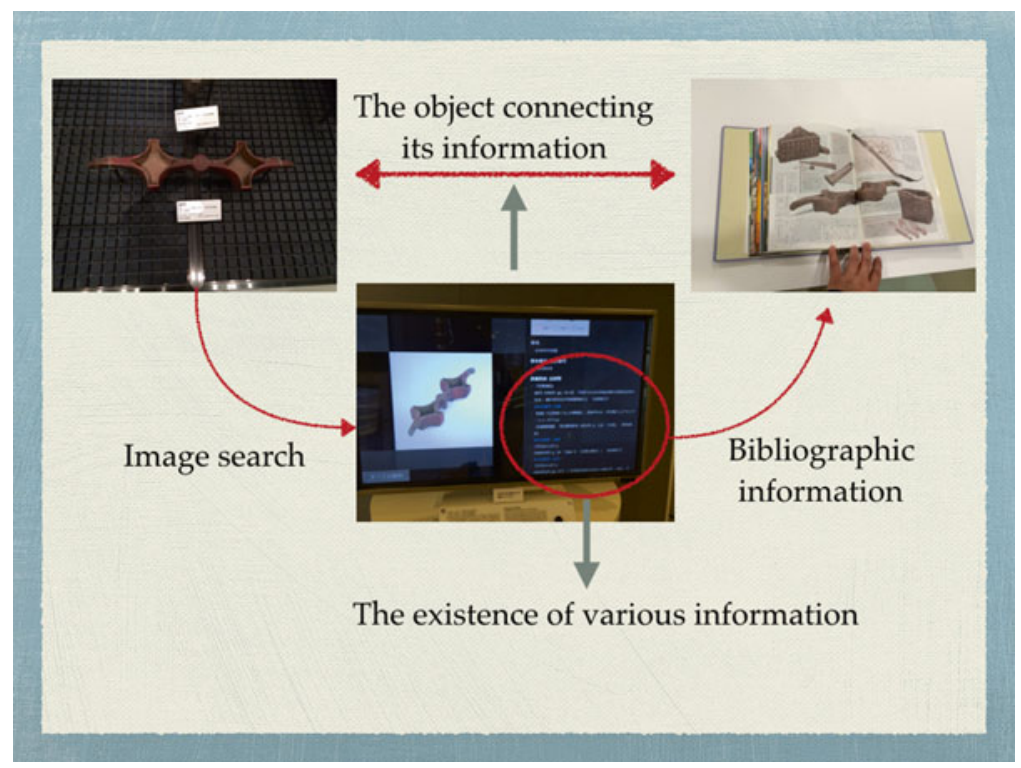

Fig. 2 Rewiring the object and its information by ImageFinder

of making or using objects concretely. It is used in museum exhibitions as a picture panel or printed in the catalogue. But there is limited space and we could not necessarily use pictures with the exhibits. In particular, the main purpose of the exhibition on "Regional Cultures of China" was to show variation in human cultures, and pictures were expected to be a useful medium for achieving it.

We planned a way of offering pictures to show the variations and changes of human culture as follows: to set pictures according to the location and time they were taken. We consulted with IT developers and designers to improve the operation system.

In MAP, pictures are distributed on a world map on a monitor screen according to the location they were taken. The users could select all of them according to the year they were taken (Fig. 3). The pictures were not necessarily concerned with the objects in the exhibition. But the users could understand the condition of the area that the exhibition was focusing on. They were also given plural "tags" concerned with the events and ethnic groups. Peoples could select and display pictures according to the time and the particular event. When a user selected a picture, a comment on it was displayed on the screen with a series of pictures that were taken at the same time.

The MAP system is currently working in the museum. However, it might be useful to use it outside the museum, especially on the Internet. In that case, it might be possible to supply and collect "big data" from the museum. 


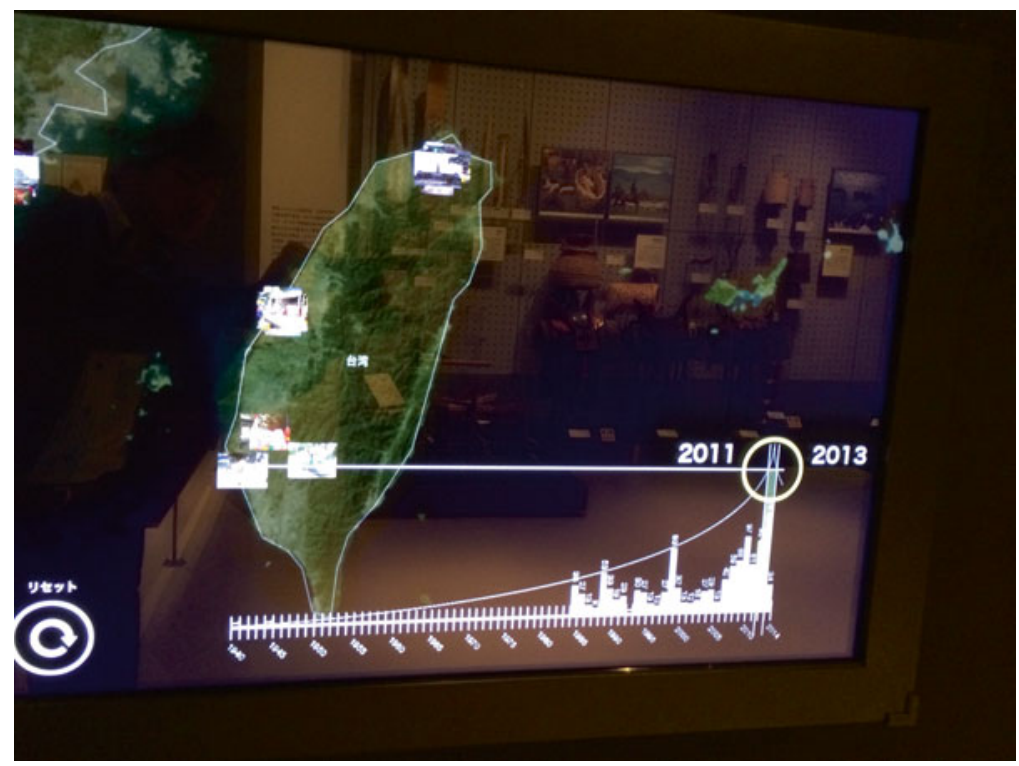

Fig. 3 Sorting pictures by years in MAP screen

We tend to think that an exhibition needs information concerned with the objects in the exhibition or the museum itself. The exhibits are a visible part of the museum and directly linked to the public. The museum has a chance to be evaluated with its exhibits. On the other hand, the exhibits change and the museum might collect additional information or new materials related to existing exhibits and materials or not. Individual exhibitions cannot continue to contribute to the museum and the public. We have to pay more attention to the materials stored in the museum. They also have rich contents or information as do the objects in current exhibitions. The museum could always open them to the public by other methods different from the exhibits. MAP could also be one of them.

A picture has rich information about people, animals, geography, weather, and artificial things including instruments, buildings, crafts, and so on. Even if a photograph has no image of people or artificial things and just shows the image of a cloud, it might be useful for meteorology with the data on the time and location. Digital cameras now record the time and location easily with a picture. It is much easier for us to order pictures according to the space and time than before.

They would also be historical records to those people who live in the area where the photographs were taken. It is more efficient and effective to open them to local society through SNS or other methods. The accumulated data would be passed down to the next generation and spread horizontally among the population with additional information. It is not necessary for the information in the museum to stay in the museum. 


\section{Conclusion}

The rapid progress of digital devices and the growth of the Internet community have changed the condition of museums, especially the way to offer information on exhibitions and the museum itself. Digital devices can handle various information that is separated from the object together because digital contents are easily duplicated. It lets the museum offer this information to the public in the museum and outside the museum at the same time. It is important to connect the information so that visitors can understand the exhibits efficiently and effectively. As a result, visitors and users might find additional information or produce new contents and feed them back to the museum. We are rewiring information from outside to the museum information. The museum and the users share the information that is not only in the museum but also in the hands of the users. This is mobility and cloud computing for information of the museum.

On the other hand, digital devices cannot autonomously offer information to visitors. We cannot imagine the museum without them, and digital devices and other digital media will become more important and develop further in future. We have partly achieved connection and integration of the museum's information by utilizing IT technologies. However, it depends on their utilization whether we can share the information with the museum visitors or users or not. We have to develop a way that stimulates visitors' intellectual curiosity and raises their literacy in dealing with museum information.

What do the objects and their information in the museum mean to us? In Minpaku, we have collected materials concerned with human culture. We have experienced rapid changes in our world during the twentieth and twenty-first centuries. We cannot see some of the material culture stored in Minpaku in their original places. We can show the existence of material culture in each period all over the world. People who are the original owners might use this information to create a new local material culture. The objects and their information in the museum will be our inheritance of intelligence on this planet.

Note ImageFinder and MAP system were developed by the cooperated work of the museum staff, designers of the exhibits and the developers of the computer system. It was also to rewire the knowledge and experience among the peoples.

Open Access This chapter is distributed under the terms of the Creative Commons AttributionNonCommercial 4.0 International License (http://creativecommons.org/licenses/by-nc/4.0/), which permits any noncommercial use, duplication, adaptation, distribution and reproduction in any medium or format, as long as you give appropriate credit to the original author(s) and the source, provide a link to the Creative Commons license and indicate if changes were made.

The images or other third party material in this chapter are included in the work's Creative Commons license, unless indicated otherwise in the credit line; if such material is not included in the work's Creative Commons license and the respective action is not permitted by statutory regulation, users will need to obtain permission from the license holder to duplicate, adapt or reproduce the material. 


\section{References}

Nobayashi, Atsushi. 2014a. A methodological study on tangible information on exhibits. In Museum stimulates sensibility - how to construct a visible, tangible, and sensual museum, ed. Y. Hirai et al., 65-96. Kyoto: Gakugei Publishing Co. Ltd.

Nobayashi, Atsushi. 2014b. You should consult the past if you want to create the future. Gekkan Minpaku 5: 6-7. (In Japanese). 


\title{
Managing and Analyzing Museum Environmental Data
}

\author{
Naoko Sonoda
}

\begin{abstract}
Two specially customized computer programs have been developed at the National Museum of Ethnology, Japan to facilitate the analysis of the museum environment: a pest monitoring data analysis program; and a temperature/relative humidity $(\mathrm{RH})$ monitoring data analysis program. These analysis programs improve understanding of the museum environment and support efficient and quick discovery of any abnormalities from a preventive conservation point of view. Daily and advanced uses of these data analysis programs were described. For example, a comparative study of the results of temperature and humidity control under the normal regime and under the power-saving regime was carried out based on actual readings, and permitted use of more energy-efficient air-conditioning control since FY2014. For the next development, it is intended to incorporate these analytical programs into "data analysis small packages" that can be used freely by other museums and related institutions.
\end{abstract}

\section{Introduction}

In this time of globalization, the role of museums in valuing tangible cultural heritage from different communities or nations, through ensuring broader access to the collections while managing their proper conservation, is gaining importance. With increasing demand of access to the collection, museums need to take good balance between access and conservation.

At the same time, the museums of the twenty-first century are required to pay consideration to its environmental impact. Two important environmental issues affecting museums are protection of the ozone layer, and climate change. The former led to a comprehensive review of policies regarding the use of chemical fumigants on cultural properties in Japan, resulting in the implementation of Integrated Pest Management (IPM). Climate change affects not only the outdoor environment but also the museum environment. We face to a dilemma how to reduce the energy consumption without generating an adverse effect to climate control within a museum.

\footnotetext{
N. Sonoda $(\bowtie)$

National Museum of Ethnology, Senri Expo Park, Suita, Osaka 565-8511, Japan

e-mail: sonoda@idc.minpaku.ac.jp 
Moreover, in Japan, energy saving becomes a serious matter after the Great East Japan Earthquake occurred in 2011.

Considering that museum collections and especially those in a museum of ethnology are frequently composed of organic materials susceptible to insect and fungal attacks, control of the museum environment is an important task. Each museum is taking action for sustainable museum environment control based on the results of museum environment investigations. Among these investigations, a huge amount of data has to be handled for pest monitoring and temperature/relative humidity (RH) monitoring. A key point is how to analyze these data effectively and efficiently from a conservation point of view. For this purpose, two specially customized computer programs have been developed at the National Museum of Ethnology, Japan in order to facilitate the analysis of the museum environment: a pest monitoring data analysis program and a temperature/RH monitoring data analysis program. These analysis programs contribute to improve understanding of the actual state of the museum environment and to find out efficiently and quickly any abnormalities from a preventive conservation point of view. Based on this, a new development is ongoing at the National Museum of Ethnology, Japan to improve these analysis programs into museum environment "analysis small packages" that can be used free of charge by any other institution.

This paper first describes examples of computer-assisted analysis of the museum environment performed at the National Museum of Ethnology, Japan and then describes briefly the ongoing development of the analysis programs.

\section{Pest Monitoring Data Analysis}

As a part of the efforts to implement IPM, pest monitoring using insect traps has been ongoing since 1992 at the National Museum of Ethnology, Japan. Two kinds of insect traps (327 sheet traps and 181 pheromone traps for cigarette beetles) are set at fixed points in different parts of the museum including the storage zone, the gallery zone and the other zone for 2 weeks and then collected. The pests captured in each trap are then counted and identified. The results are collected on a Microsoft Excel sheet in which the pest species damaging the museum collection and captured so far in our museum are figured (Table 1).

\subsection{Daily Use}

The pest monitoring data analysis program is currently used to make different graphs (line graphs or bar graphs) and traps mapping.

After each seasonal investigation, the newly acquired data are checked systematically through comparison with data from the same season of the previous years; this is in order to judge whether the current situation is normal or not. If any problem 
Table 1 Pest list used at the National Museum of Ethnology, Japan for monitoring pests

\begin{tabular}{|c|c|}
\hline \multirow[t]{20}{*}{ Coleoptera (Beetle, Weevil) } & Anthrenus verbasci \\
\hline & Attagenus japonicus Reitter \\
\hline & Other Dermestidae* \\
\hline & Dinoderus minutus (Fabricius) \\
\hline & Other Bostrychidae* \\
\hline & Lyctus brunneus (Stephens) \\
\hline & Other Lyctidae* \\
\hline & Stegobium paniceum (Linnaeus) \\
\hline & Lasioderma serricorne (Fabricius) \\
\hline & Other Anobiidae* \\
\hline & Ptinidae \\
\hline & Sitophilus zeamais \\
\hline & Other Rhynchophoridae (added in April, 2007) \\
\hline & Tribolium castaneum \\
\hline & Other Tenebrionidae \\
\hline & Curculionoidea \\
\hline & Oryzaephilus surinamensis \\
\hline & Other Silvanidae \\
\hline & Cerambycidae* $^{*}$ \\
\hline & Other Coleoptera* \\
\hline \multirow[t]{4}{*}{ Lepidoptera (Moth and Butterfly) } & Tinea translucens Meyrick \\
\hline & Tineola bisselliella \\
\hline & Pyralidae \\
\hline & Other Lepidoptera* \\
\hline \multirow[t]{4}{*}{ Blattaria (Cockroach) } & Periplaneta fuliginosa (Serville) \\
\hline & Periplaneta americana (Linnaeus) \\
\hline & Blattella germanica (Linnaeus) \\
\hline & Other Blattaria \\
\hline \multirow[t]{2}{*}{ Thysanura (Bristle teil) } & Ctenolepisma villosa (Fabricius) \\
\hline & Other Thysanura* \\
\hline \multirow[t]{2}{*}{ Psocoptera (Booklouse) } & Liposcelidae \\
\hline & Other Psocoptera* \\
\hline \multirow[t]{3}{*}{ Orthoptera (Orthopteron) } & Rhaphidophoridae \\
\hline & Gryllidae \\
\hline & Other Orthoptera \\
\hline \multirow[t]{2}{*}{ Isoptera (Termite, White ant) } & Reticulitermes speratus (Kolbe) \\
\hline & Other Isoptera* \\
\hline \multirow[t]{3}{*}{ Diptera (Fly) } & Diptera, orinigated from inside (added in July, 2008) \\
\hline & Diptera, originated from outside (added in July, 2008) \\
\hline & Other Diptera or all Diptera before July 2008 \\
\hline \multirow[t]{2}{*}{ Hymenoptera (Sawfly, Wasp, Bee, Ant) } & Formicidae* \\
\hline & Other Hymenoptera \\
\hline
\end{tabular}


Table 1 (continued)

\begin{tabular}{l|l}
\hline Thysanoptera (Thrip) & All Thysanoptera \\
\hline \multirow{2}{*}{ Hemiptera (Truebug) } & Heteroptera \\
\cline { 2 - 2 } & Aphidoidea \\
\cline { 2 - 2 } & Cicadellidae \\
\cline { 2 - 2 } & Homoptera \\
\cline { 2 - 2 } & Psylloidea \\
\cline { 2 - 2 } & Other Hemiptera \\
\hline Collembola (Springtail) & All Collembola \\
\hline Dermaptera (Earwig) & All Dermaptera \\
\hline Other Insecta & All other Insecta (added in April, 2007) \\
\hline Arachnida/Acari (Mite, Tick) & All Acari \\
\hline Arachnida/Araneae (Spider) & All Araneae \\
\hline $\begin{array}{l}\text { Malacostraca/Isopoda } \\
\text { (Woodlouse, Pill bug) }\end{array}$ & All Isopoda \\
\hline Diplopoda (Millipede) & \\
\hline Chilopoda (Centipede) & All Diplopoda \\
\hline Others & All Chilopoda \\
\hline
\end{tabular}

*If found, species should be specified

is discovered, the possible causes of the abnormalities are to be clarified through an in-situ inspection by museum staff and necessary measures taken.

The original traps mapping program based on Microsoft Excel is an effective tool to visualize the geographic concentration of the pests as well as the distribution of the pest species. As an example, the traps mapping of the results of our investigation in winter 2015 is given in Fig. 1.

- The geographic concentration of the pests is presented; the darker the color, the more concentrated the number of the pests captured. We remark that a very few pests are captured in the storage zone (dark gray area).

- From the distribution of the pest species, we observe that pests trapped in the other zone (light gray area) are mostly flies in the corridors near the shutter doors $(\vec{\square})$.

\subsection{Advanced Use}

A review of the data accumulated since 1992 contributes to understand the pest trends in the museum (Sonoda and Hidaka 2011).

- Pests are most frequently captured in summer, followed in order by spring, autumn, and winter. There are no clear seasonal characteristic in the species captured, probably because the museum environment is controlled for human 


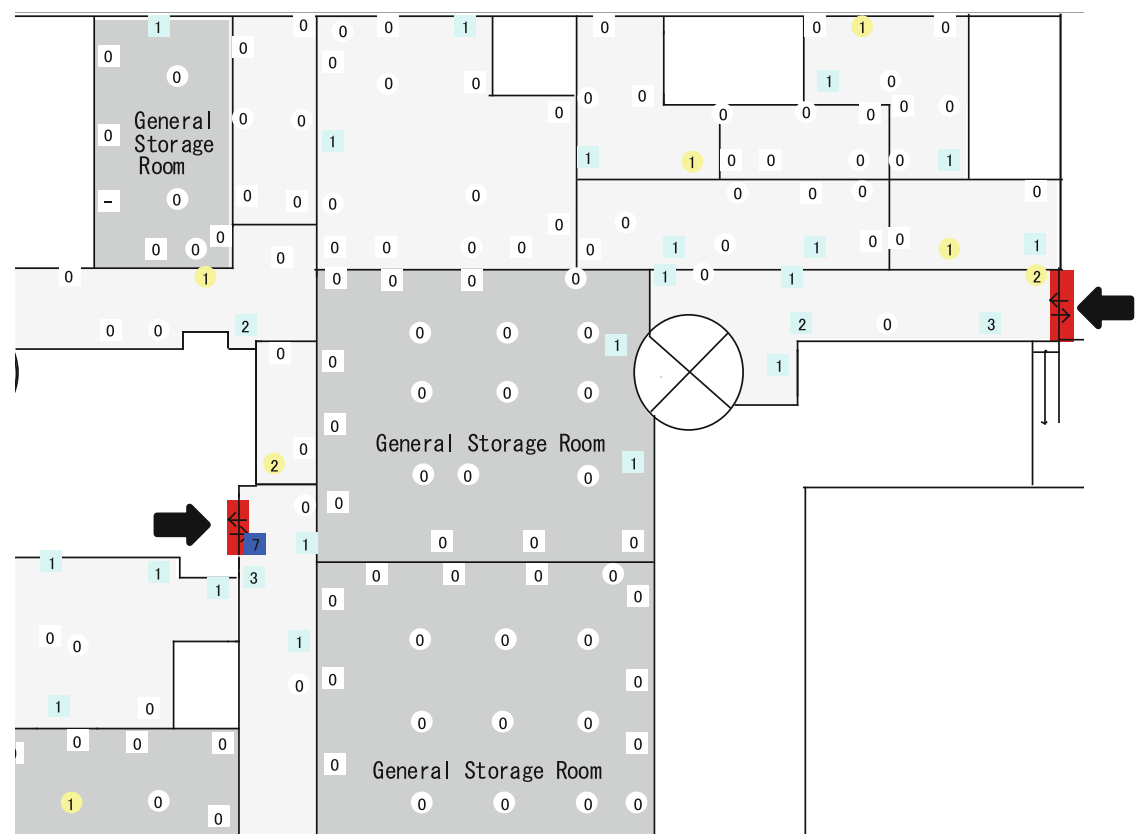

Geographic concentration of the pests: the total number of the pests captured in each trap (upper)

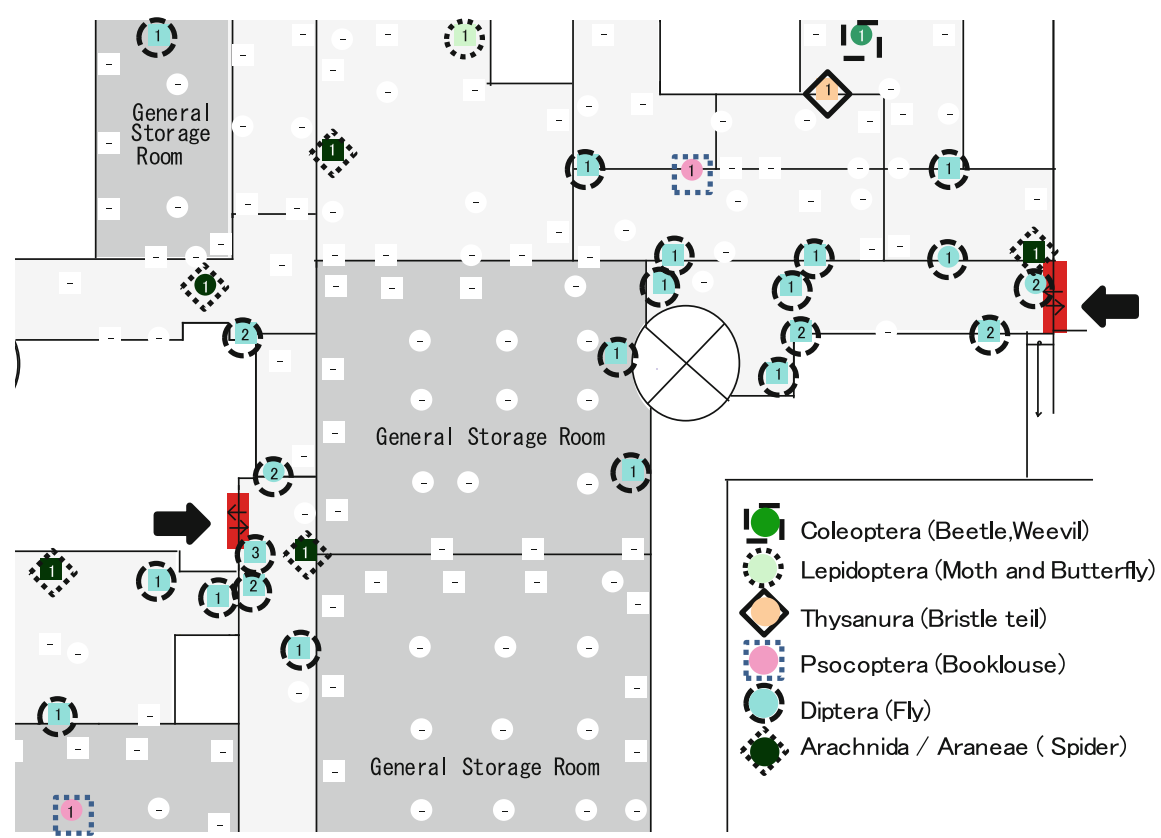

Distribution of the pest species: the most captured pest species in each trap (lower)

Fig. 1 Traps mapping: Geographic concentration of the pests (upper) and distribution of the pest species (lower) from the results of the investigation winter 2015. Dark gray area: storage zone Light gray area: other zone. $\square$ Sheet traps $\bigcirc$ Pheromone traps 


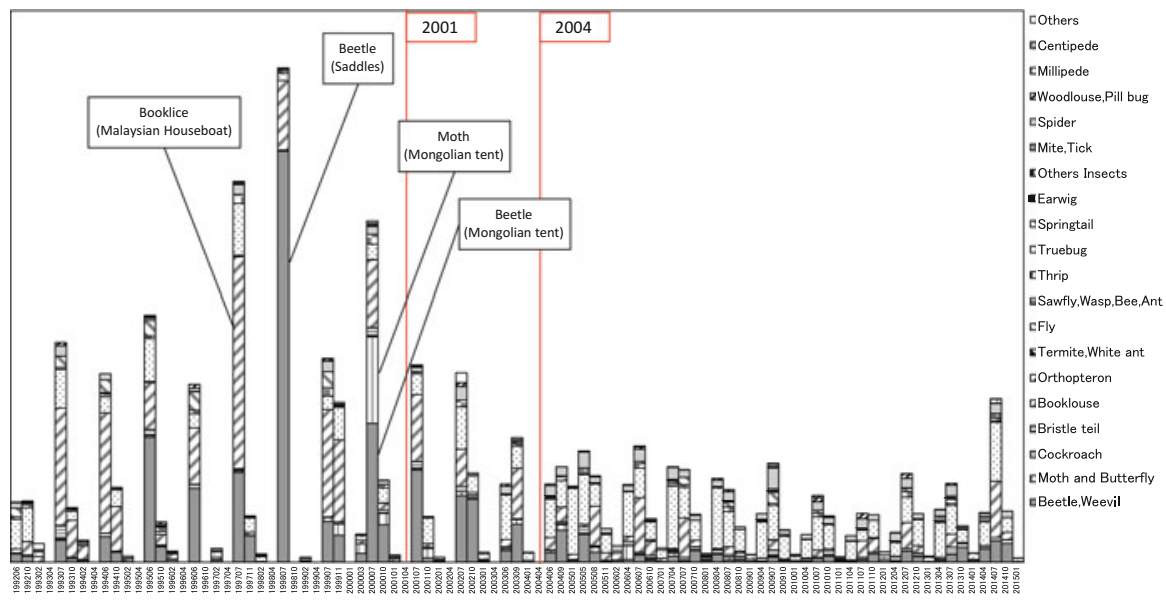

Fig. 2 Relative changes in the numbers of pests trapped in the gallery zone from 1992 to 2015

comfort and consequently for pest comfort throughout the year. In the storage zone, constant attention should be paid to booklice, beetles and moths. In the gallery and other zones, pests originating from outside the museum are frequently captured: flies in all seasons; spiders in spring and winter, and woodlice in summer and autumn. Booklice always rank among the most frequently captured species, except in the gallery and other zones in spring, which is a dry season in Osaka (where the National Museum of Ethnology, Japan is located).

- In the period 1992-1999, the most frequently captured species were booklice and beetles, the latter becoming more prevalent around 1997-1999. Between 1999 and 2000, there was a local outbreak of moth, and from 2001 a marked increase in flies. At the beginning of the investigation, booklice were found mainly in the storage and gallery zones, yet are now observed mainly in the other zone. Beetles are captured mainly in the storage and gallery zones, although their numbers have clearly decreased in recent years. Moths were found almost exclusively in the storage zone in 1999-2000, during work to replace air conditioning ducts. Flies have appeared frequently in the other zone since 2001. The occurrence of pests has changed location from the storage and gallery zones to the other zone; this change occurred in 2001 when we started to strengthen communication between different sections based on the principles of IPM.

- In the gallery zone, there is a clear tendency for pin-point attacks. Some objects such as a houseboat in the Southeast Asia gallery and a Mongolian tent in the North Asia gallery have been suffering regularly from pest attacks. This observation led us, in 2004, to introduce an IPM inspection (visual observation of the objects most prone to pest/fungus attacks) at the time of the daily rounds in the exhibition galleries before the museum opens. Figure 2 shows relative changes in the number of pests trapped in the gallery zone from 1992 to 2015, indicating that the situation improved on two occasions, in 2001 and in 2004. The former is 
the date on which we started to strengthen communication between different sections as noted above, thus confirming the importance of better communication and daily attention.

- In the storage zone, pest attacks tend to spread. This can be attributed to the density of the objects in the storage zone. Another possible reason is that, in the storage zone, in comparison with the gallery zone, the objects are not exposed to human eyes as often, thus preventing early detection. Therefore, it was decided that different storage rooms be cleaned regularly, finishing with a rapid IPM inspection of all the objects stored in the respective rooms. In this way, each room is cleaned and each object is given a cursory inspection at least once a year.

\section{Temperature/RH Monitoring Data Analysis}

Monitoring temperature and RH with data loggers started in 2004, to complement the classical monitoring using thermo-hydrographs. Currently, nearly 150 data loggers are used mainly covering the storage zone and the gallery zone. As of January 2015, we have accumulated $26 \mathrm{~GB}$ of data in our temperature and RH database.

\subsection{Daily Use}

Temperature and RH data are checked sequentially by the central surveillance center and necessary measures taken as the need arises. Data are solely reviewed every 2 weeks and shared between museum staff of different sections. Every month, the newly acquired data are presented in graphs using the temperature/RH monitoring data analysis program and checked in order to judge whether the current situation is normal or not. If any problem is discovered, the possible causes of the abnormalities are to be clarified and necessary measures taken.

\subsection{Advanced Use}

In order to overcome the electricity shortage due to the Great East Japan Earthquake of March 2011, 10-15\% reduction in electricity use (in comparison with 2010) was requested in winter 2011 and in summer 2012, leading us to adopt a power-saving regime for several general storage rooms.

The storage rooms at the National Museum of Ethnology, Japan are divided into two types: general storage rooms and special storage rooms. Most of the items in the museum collections are made of composed materials and are placed in general storage rooms under collection classifications, without any sorting by material. Special storage rooms house artifacts made of sensitive materials requiring finely tuned air-conditioning control, as well as items which require special security arrangements. 
Table 2 Temperature and RH settings under the normal, power-saving, and new regimes for general storage rooms

\begin{tabular}{|c|c|c|c|c|}
\hline & Spring & Summer & Autumn & Winter \\
\hline \multirow[t]{3}{*}{$\begin{array}{l}\text { NORMAL } \\
\text { regime }\end{array}$} & $\begin{array}{l}\text { Adjustments } \\
\text { made in } \\
\text { increments of } \\
0.5^{\circ} \mathrm{C} / \text { week }\end{array}$ & $26 \pm 2{ }^{\circ} \mathrm{C}$ & $\begin{array}{l}\text { Adjustments } \\
\text { made in } \\
\text { decrements of } \\
0.5^{\circ} \mathrm{C} / \text { week }\end{array}$ & $20 \pm 2{ }^{\circ} \mathrm{C}$ \\
\hline & \multicolumn{4}{|l|}{$52 \pm 5 \% \mathrm{RH}$} \\
\hline & \multicolumn{4}{|l|}{$8: 20-18: 00$} \\
\hline \multirow{3}{*}{$\begin{array}{l}\text { POWER } \\
\text { SAVING } \\
\text { regime }\end{array}$} & \multirow[t]{3}{*}{ OFF } & $26 \pm 2^{\circ} \mathrm{C}$ & \multirow[t]{3}{*}{ OFF } & $20 \pm 2^{\circ} \mathrm{C}$ \\
\hline & & $52 \pm 5 \% \mathrm{RH}$ & & $52 \pm 5 \% \mathrm{RH}$ \\
\hline & & $\begin{array}{l}\text { Only Wednesdays } \\
\text { and Sundays }\end{array}$ & & $\begin{array}{l}3-4 \mathrm{~h} \text { at night } \\
\text { everyday }\end{array}$ \\
\hline \multirow{4}{*}{$\begin{array}{l}\text { NEW regime } \\
\text { since FY2014 }\end{array}$} & \multirow[t]{4}{*}{ OFF } & $26 \pm 2{ }^{\circ} \mathrm{C}$ & \multirow[t]{4}{*}{ OFF } & $20 \pm 2^{\circ} \mathrm{C}$ \\
\hline & & $52 \pm 5 \% \mathrm{RH}$ & & $52 \pm 5 \% \mathrm{RH}$ \\
\hline & & $8: 20-18: 00$ & & $8: 20-18: 00$ \\
\hline & & $\begin{array}{l}\text { Air conditioning } \\
\text { starts when } \\
\text { temperature }>25 \\
{ }^{\circ} \mathrm{C} \text { or }>65 \% \mathrm{RH} \\
\text { for more than one } \\
\text { week }\end{array}$ & & $\begin{array}{l}\text { Air conditioning } \\
\text { starts when } \\
\text { temperature is too } \\
\text { cool for museum } \\
\text { staff to work or } \\
<40 \% \text { RH }\end{array}$ \\
\hline
\end{tabular}

Before the power-saving regime (normal regime), the general storage rooms were air-conditioned daily between 08:20 and 18:00. The temperature was set at $26 \pm 2{ }^{\circ} \mathrm{C}$ in summer and at $20 \pm 2{ }^{\circ} \mathrm{C}$ in winter, varying $0.5^{\circ} \mathrm{C}$ per week in the transitional periods, while $\mathrm{RH}$ was set at $52 \pm 5 \%$ all the year. The power-saving regime was adopted for general storage rooms. Under the power-saving regime, the airconditioning was turned off during the transitional periods. During the winter of 2011, air-conditioning was run only at night during the off-peak period. In summer 2012, air-conditioning was only run for 24 h, 2 days a week (Table 2). However, one of the general storage rooms (Room No. 5) was exempted from these power-saving measures as it was situated in upstairs and not surrounded by other rooms. Consequently this room is easily exposed to the effects of outside air.

The results of temperature and humidity control under the normal regime and the power-saving regime were examined and compared based on actual readings (Sonoda and Hidaka 2013).

- For the transition periods, temperature changes occurred more gradually with the suspension of air-condition under the power-saving regime than under the normal regime, resulting in smaller fluctuations in temperature and in $\mathrm{RH}$.

- Under the normal regime, the average temperature remained within the control range in all of the storage rooms, whereas it tended to drop below the control range under the power-saving regime. The maximum daily difference between the lowest and the highest temperature readings was less than $4{ }^{\circ} \mathrm{C}$ (even less than $2{ }^{\circ} \mathrm{C}$ in several rooms) under both regimes, except in Room No.5. The average daily difference was around $2{ }^{\circ} \mathrm{C}$ or less (even less than $0.5^{\circ} \mathrm{C}$ in several rooms) under both regimes, except in Room No.5. 
- The average RH was slightly higher during the summer period under the powersaving regime (around $60 \% \mathrm{RH}$ ) but otherwise remained largely within the control range. The maximum daily difference in RH was $10 \% \mathrm{RH}$ or less under both regimes in most storage rooms, but in some storage rooms this value exceeded $10 \% \mathrm{RH}$ during spring and summer. The average daily difference in RH was less than $5 \% \mathrm{RH}$ under both regimes except the summer period under the normal regime where it exceeded this value.

- No significant difference between the two regimes was observed in the annual temperature difference. The annual RH difference was greater under the powersaving regime than under the normal regime. However, weekly transition in temperature and in RH was comparable under both regimes except the summer period under the power-saving regime where greater temperature and $\mathrm{RH}$ fluctuations were observed.

From all these observations, it was concluded that the temperature and humidity control level was acceptable under both regimes except the summer period under the power-saving regime. This study resulted in the adoption of energy-efficient airconditioning control (the new regime) since fiscal year 2014 (Table 2). Under the new regime, air-conditioning is switched off in spring and autumn, and starts when the temperature or RH values become too high in summer or too low in winter. If the power-saving regime is requested, we opt to reduce the air-conditioning time by running the air-conditioning for just a short period every day and not by alternating between no-air-conditioning days and 24-h-operation days in order to avoid temperature and humidity fluctuations.

Figure 3 compares actual data from one of the general storage rooms under the normal, power-saving, and new regimes.

- For spring and autumn, temperature changes occurred more gradually with the suspension of air-conditioning under the power-saving regime and the new regime (-je than under the normal regime, resulting in smaller daily fluctuations in temperature and in $\mathrm{RH}$.

- After a period of no air-conditioning in spring 2014, the temperatures in the storage rooms were actually lower than the temperature setting of the air-conditioning on the day the air-conditioning was scheduled to be switched on, and this allowed the use of air-conditioning to be delayed ( $\square$ ).

- At the beginning of December 2014, several museum staff felt that the temperature was becoming too cold. We started air-conditioning 1 week earlier than the

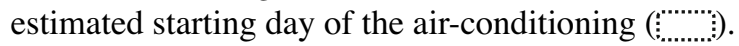

- The above two observations led us to conclude that the suspension of airconditioning in the transition periods may allow the use of air-conditioning to be delayed, but this depends on the outside climate at the time.

Figure 4 compares the weekly distributions in temperature and $\mathrm{RH}$ for each season for the same general storage room as in Fig. 3. An ellipse was drawn for each week to include $90 \%$ of the data. The size of each ellipse reflects the fluctuation; the greater the size, the greater the weekly fluctuation in temperature and/or RH. The idea for this ellipse analysis came from a previous study done in our museum (Morita 1981). 
Spring

Summer

Autumn

Winter

NORMAL regime (April 2010-March 2011)
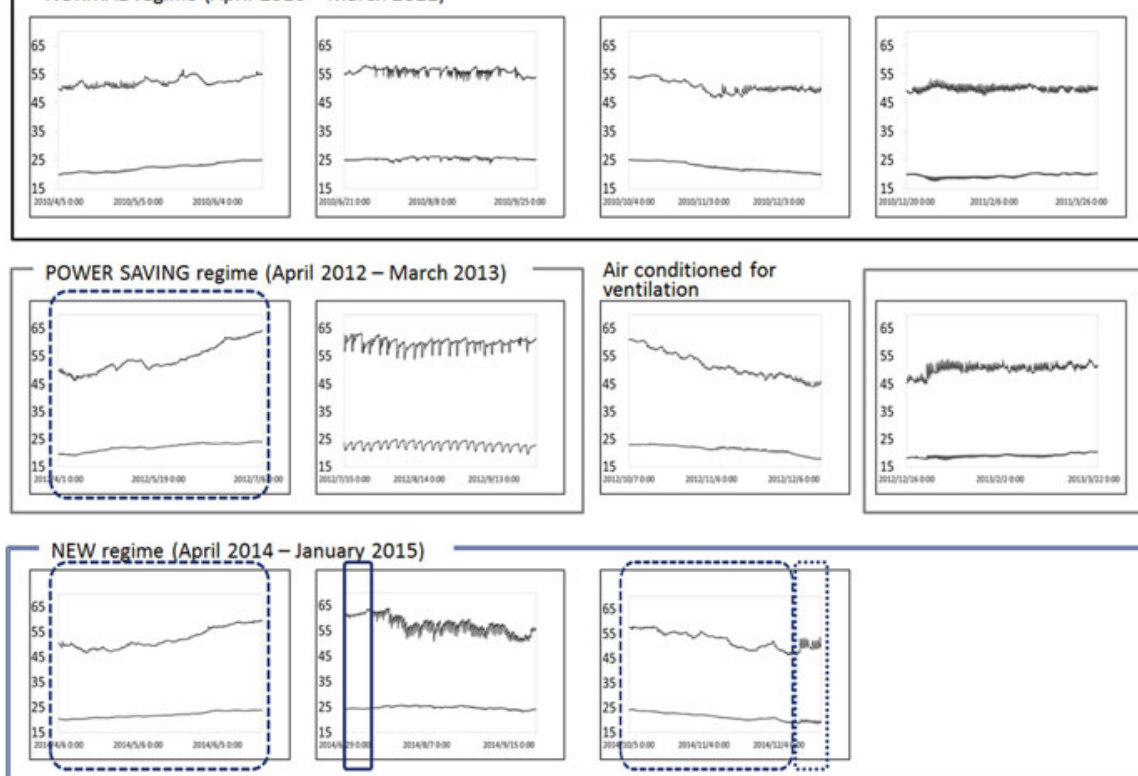

Fig. 3 Annual data from one of the general storage rooms under the normal (upper), power-saving (middle), and new (lower) regimes. Upper lines: relative humidity (\%RH). Lower lines: temperature $\left({ }^{\circ} \mathrm{C}\right)$

- At the weekly level, fluctuations were comparable and acceptable under the different regimes for the transition periods of spring and autumn as well as for winter, as shown by the similar small sizes of the ellipses.

- In summer however, much greater ellipses were observed under the power-saving regime, suggesting bigger temperature and RH fluctuations ( $\square$ ).

Overall, we estimate that, except for the summer period under the power-saving regime, there were no sudden fluctuations in temperature and $\mathrm{RH}$, and weekly transitions in temperature and in RH were more or less comparable under the three regimes.

\section{Future Development}

As the next development, we plan to develop these data analysis programs (pest monitoring data analysis program, and temperature/RH monitoring data analysis program) and to make "data analysis small packages" that can be used free of charge by any other institution. We are at the stage of making further program changes and 


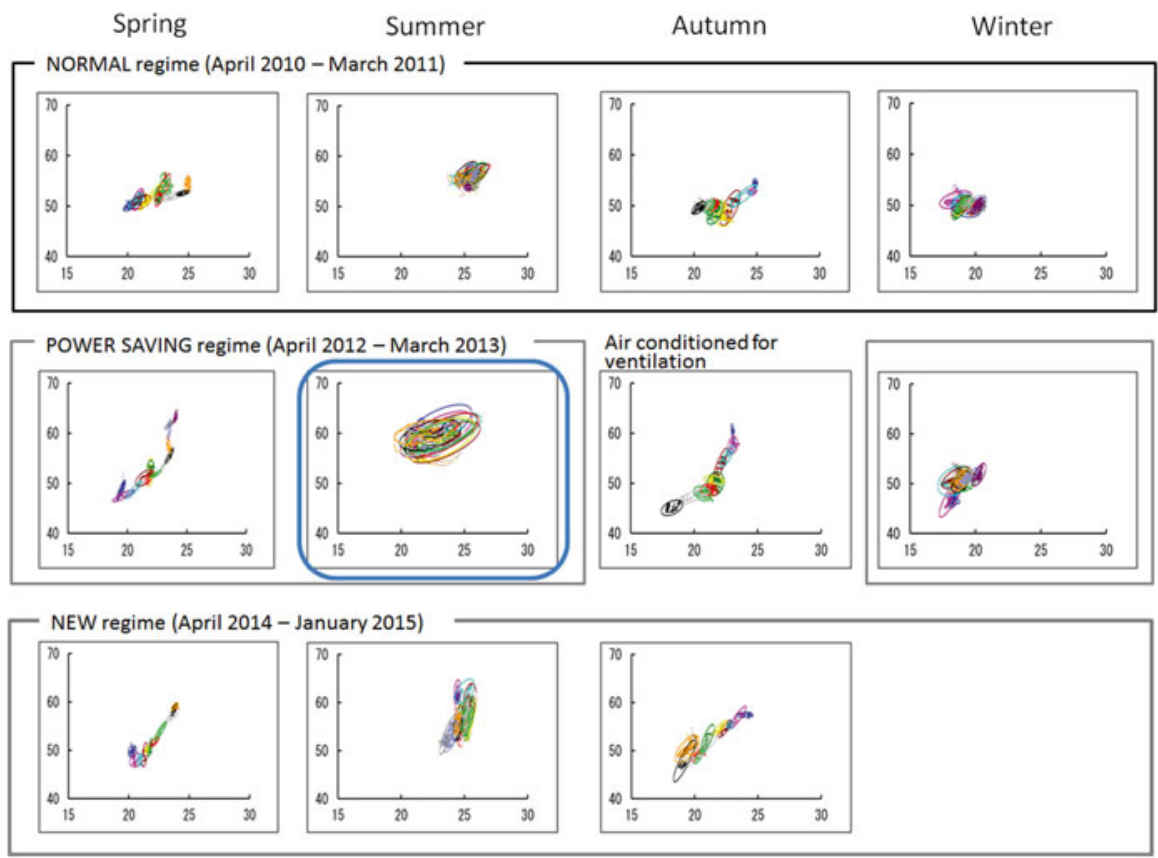

Fig. 4 Weekly distributions in temperature and in RH for each season for the same general storage room as in Fig. 3 under the normal (upper), power-saving (middle), and new (lower) regimes. $X$ axis: temperature $\left({ }^{\circ} \mathrm{C}\right) . Y$ axis: relative humidity $(\% \mathrm{RH})$

improvement, after having received comments and requests by researchers who kindly had accepted to use the prototype version of the "temperature/RH monitoring data analysis small package." We hope that the Japanese version will be available in the near future. The English one is in the planning stage.

Both the "pest monitoring data analysis small package" and "temperature/RH monitoring data analysis small package" are conceived on the same principles: simple and easy for anyone to use without receiving any special training. The systems required for these data analysis small packages are: Windows 8 (64 bits) or Windows 8.1 (64 bits); CPU Intel Core i5; memory 4 GB; Microsoft Excel 2010 (64 bits); and disk capacity of more than $500 \mathrm{~GB}$.

The starting window contains six tool buttons (Fig. 5):

- The "Data Fetching" button is used to go to a data fetching window.

- The "Graphs Making" button is used to go to a graph and/or mapping setting window.

- In the case of pest monitoring data analysis, we have a choice between graphs making and maps making. Graphs can be chosen between bar graphs and line graphs. Maps are of two sorts: geographic concentration of the pests; and distribution of the pest species. 


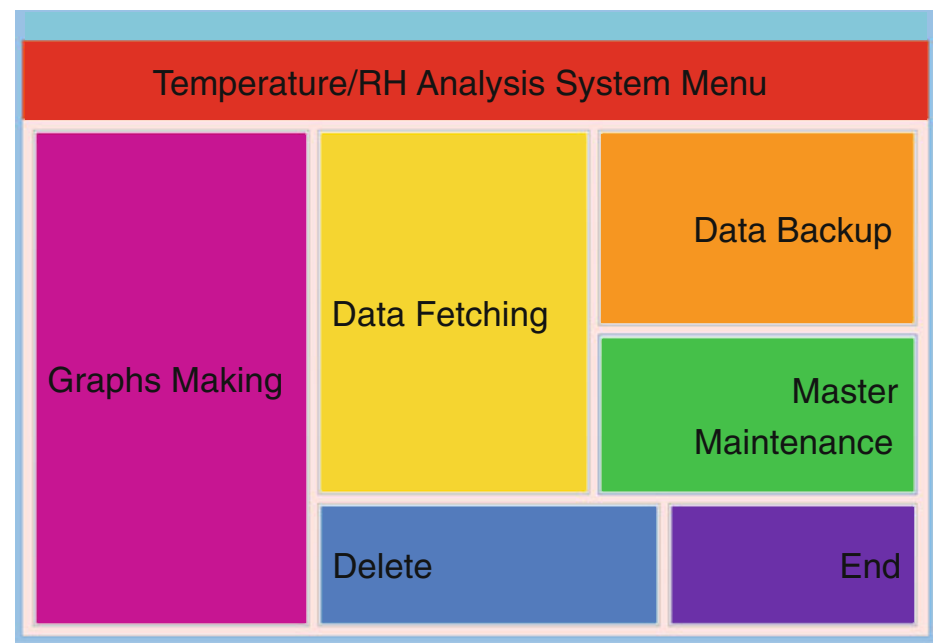

Fig. 5 Starting window of the temperature/RH data analysis small package (image)

- In the case of temperature/RH monitoring data analysis, we can select either graphs making or temperature/RH distribution maps. Graphs can be drawn for temperature, for $\mathrm{RH}$, or for both. For temperature/RH distribution maps, each data is presented as an intersection of temperature ( $\mathrm{X}$ axis) and $\mathrm{RH}$ ( $\mathrm{Y}$ axis). An ellipse can be drawn to insert $90 \%$ of data, and thus it becomes easy to find out the abnormal data.

- "Master Maintenance" is used to go to a master maintenance window. It allows the registration of the master information, such as the geographic information and the pest species list.

- The geographic information is given using three levels: in case of National Museum of Ethnology, Japan, the first and the biggest level is "Zone" (such as the storage zone, the exhibition zone, and the other zone), each zone is divided into the second level "Room". In each room, we have the third and the lowest level corresponding to each trap. It is up to the user to select the three levels, for example, the others may choose building as the first level, floor as the second level, and trap as the third level.

- The species list is classified using two levels: the first level "Order" is divided into the second level "Family, Species".

- "Data Backup" is used to go to a data backup window.

- The "Delete" button is used to go to a delete window from which we can delete acquired data.

- The "End" button is used to end the program.

- From each window, we just need to follow and check the instructions one by one. It is designed to be used instinctively. 


\section{Conclusion}

Two specially customized analysis programs (pest monitoring data analysis program and temperature/RH monitoring data analysis program) have been developed at the National Museum of Ethnology, Japan for the analysis of the museum environment, and some concrete examples of use and application in our museum were shown. As the next development, we intend to improve these analysis programs into "Data analysis small packages" that can be used free of charge by other museums or related institutions. The Japanese version will be available in the near future and the English one is in the planning stage.

It goes without saying that the development of the analysis programs and that of the "analysis small packages" are not the sole aim in itself. These computer-assisted analyses are just a tool for giving insight into general trends, highlighting deficient areas of the museum from the viewpoint of museum environment control, facilitating further analysis of the museum environment, and helping us in decision-making for a short- to long-term collection management strategy. They are certainly of some help especially when dealing with a huge amount of data. However, the most important thing is what we do, after obtaining the analysis results, in order to improve the museum environment.

Open Access This chapter is distributed under the terms of the Creative Commons AttributionNonCommercial 4.0 International License (http://creativecommons.org/licenses/by-nc/4.0/), which permits any noncommercial use, duplication, adaptation, distribution and reproduction in any medium or format, as long as you give appropriate credit to the original author(s) and the source, provide a link to the Creative Commons license and indicate if changes were made.

The images or other third party material in this chapter are included in the work's Creative Commons license, unless indicated otherwise in the credit line; if such material is not included in the work's Creative Commons license and the respective action is not permitted by statutory regulation, users will need to obtain permission from the license holder to duplicate, adapt or reproduce the material.

\section{References}

Morita, Tsyuneyuki. 1981. Microclimatic conditions within the National Museum of Ethnology. Bulletin of the National Museum of Ethnology 6(1): 159-182. (In Japanese with an abstract in English).

Sonoda, Naoko, and Hidaka, Shingo. 2011. Integrated pest management at the National Museum of Ethnology, Japan: Re-evaluation of preventive measures and control strategies. In Integrated pest management for collections. Proceedings of 2011: A Pest Odyssey, 10 Years Later. London, 26-28 October 2011, ed. Peter Winsor, David Pinniger, Louise Bacon, Bob Child, Kerren Harris, Dee Lauder, Julie Phippard and Amber Xavier-Rowe, 123-138. Swindon: English Heritage.

Sonoda, Naoko, and Hidaka, Shingo. (Oral communication). Sustainable and environmental friendly museum environment: A case study from the National Museum of Ethnology after the Great East Japan Earthquake. In Cultural heritage conservation science and sustainable development: experience, research, innovation, International conference in the frame of the 50th anniversary of the Centre de recherche sur la conservation des collections. Paris, 23-25 Oct 2013. 


\section{Part III \\ Balance Between Conservation and Access for Museums}




\title{
Exhibition, Conservation, and Documentation at the National Museum (Nay Pyi Taw)
}

\author{
Aye Aye Thinn
}

\begin{abstract}
The National Museum (Nay Pyi Taw) is under construction and the first phase was opened on 15 July 2015. The exhibition policy is: to present national prestige and integrity; to reveal national cultural heritage to show the soft power and ability of the nation; to build a museum fitting the nation's prestige and grade; and to construct the museum as a good, modern, and attractive one with the right preservation techniques and of a high standard. A total of 12,975 objects have been collected, some excavated from ancient sites and others provided by donation, exchange, or given as awards. Each object arriving at the museum is systematically documented and is being conserved with simple chemicals and ordinary equipment. There is a need for modern techniques of conservation, documentation, and exhibition.
\end{abstract}

\section{Introduction}

The Ministry of Culture has four pillars: Ministers' Office, Department of Fine Arts, Department of Historical Research, and Department of Archaeology and National Museum.

The National Museum (Nay Pyi Taw) is one of the sections under the Department of Archaeology and National Museum. Before 2010, there was only one national museum in Myanmar. The National Museum (Nay Pyi Taw) is situated on 35.19 acre plot on Yazathingaha Road, near lotus Kumudra round about in Uttara Thiri township in Nay Pyi Taw (Figs. 1 and 2). Ground breaking for construction of the museum was started on 3 June 2010. In fact, the National Museum (Nay Pyi Taw) consists of eight buildings but only five buildings have currently been constructed (Fig. 3) and the total floor area is 298,865 square feet. Building (A) has a reception hall, theater, VIP rooms, and reception counter. Building (B) consists of six rooms,

\footnotetext{
A.A. Thinn $(\bowtie)$

National Museum (Nay Pyi Taw), Yazathingaha road, Uttara Thiri township, Nay Pyi Taw, Myanmar

e-mail: aathinn.thinn6@gmail.com 


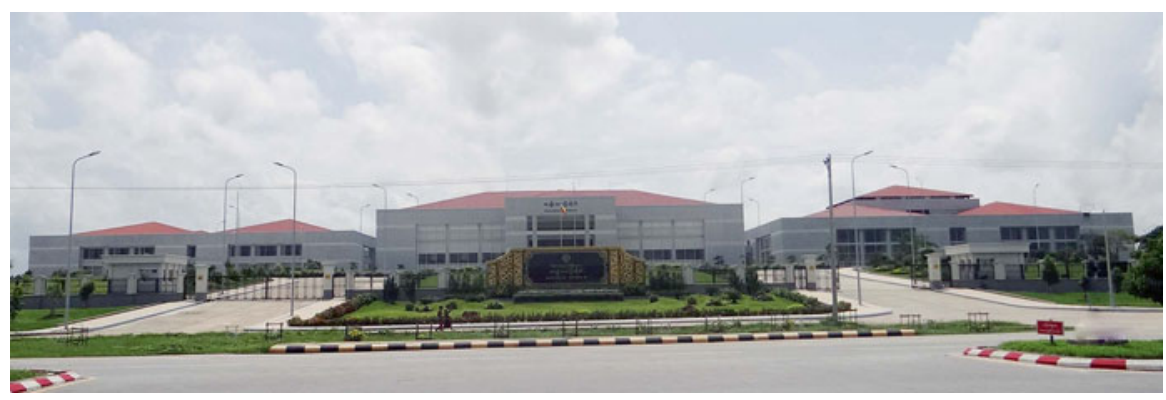

Fig. 1 National museum (Nay Pyi Taw)

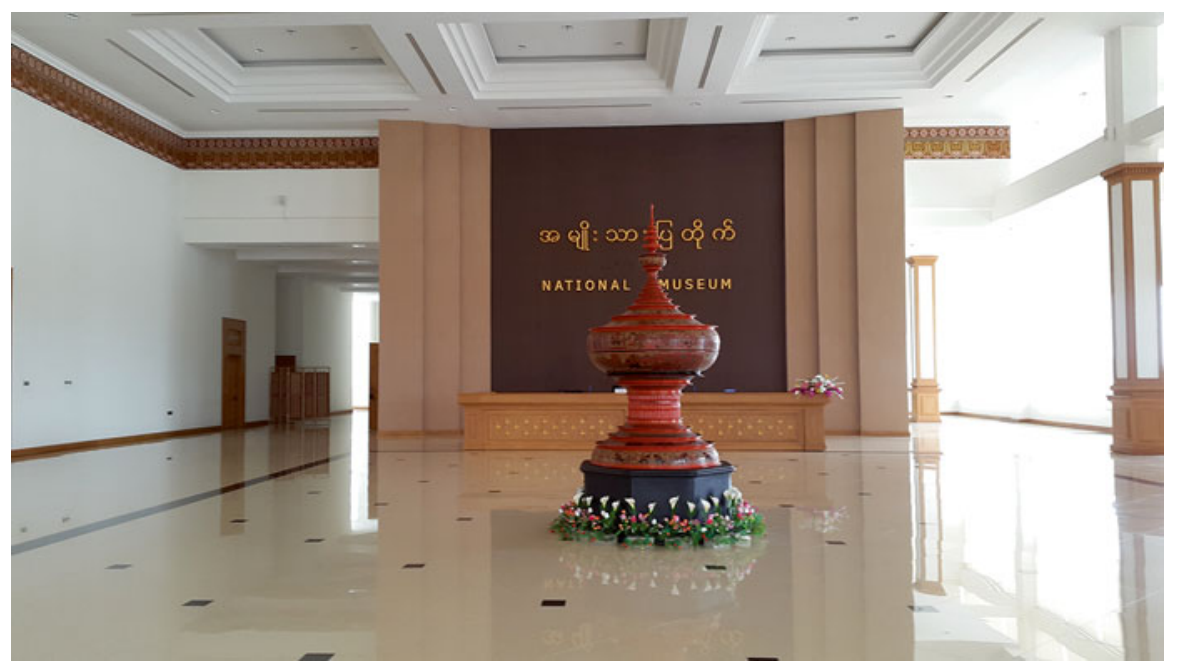

Fig. 2 Reception hall of the National Museum (Nay Pyi Taw)

Building (C) has five rooms, Building (D) has four rooms, and Building (E) has four rooms. Altogether, there are $19(100 \mathrm{ft} \times 100 \mathrm{ft})$ rooms in the National Museum (Nay Pyi Taw).

Our exhibition policy is as follows:

1. To present national prestige and integrity

2. To reveal our national cultural heritage, which is rich and of a high standard

3. To show the soft power and ability of our nation

4. To build a museum fitting our nation's prestige and grade

5. To construct the museum as a good, modern, and attractive one with the right preservation techniques and of a high standard

According to the policy, the National Museum (Nay Pyi Taw) has been constructed and there will be 17 exhibition rooms as follows:

1. Primate and Fossils exhibition room

2. Prehistoric Period exhibition room 


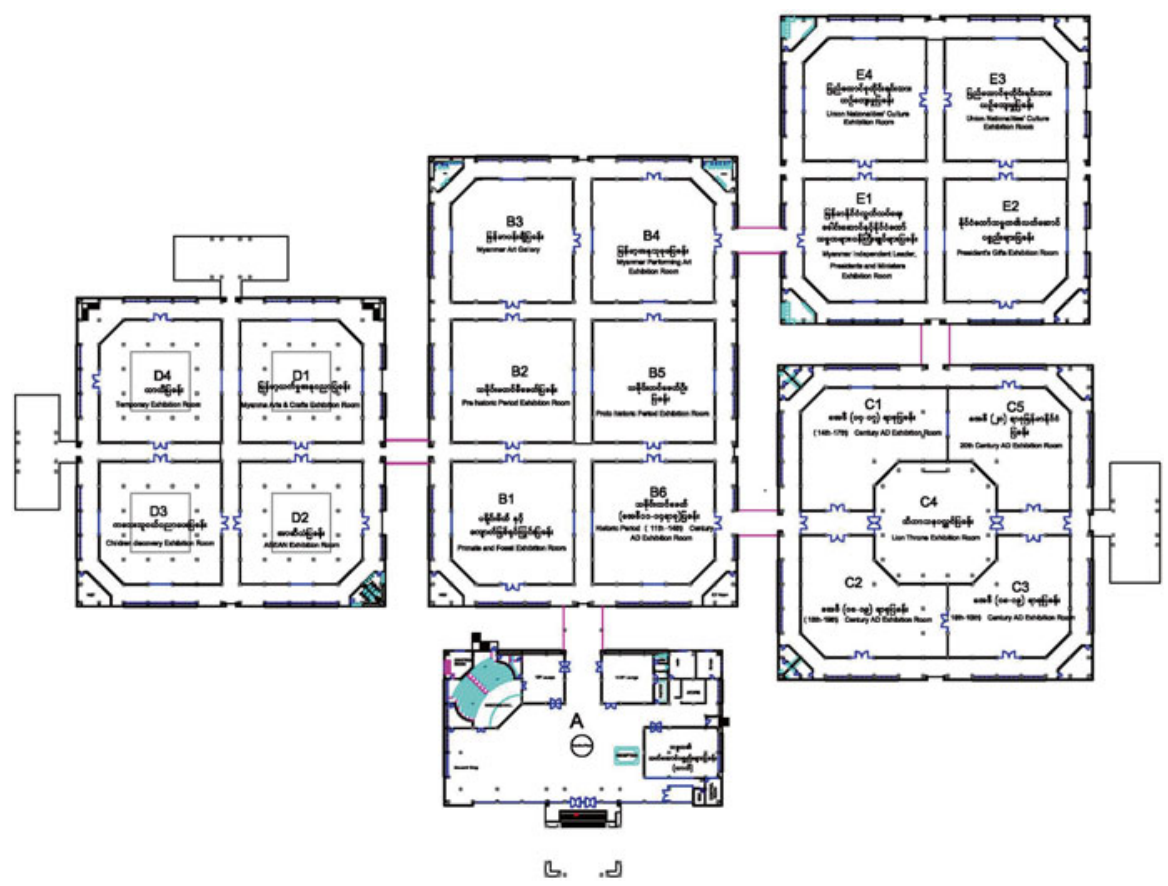

Fig. 3 Current condition of National Museum (Nay Pyi Taw): five buildings have been constructed

3. Protohistoric Period (second century BC to tenth century AD) exhibition room

4. Historic Period of eleventh to thirteenth century AD exhibition room

5. Historic Period of fourteenth to seventeenth century AD exhibition room

6. Historic Period of eighteenth to nineteenth century AD exhibition room

7. Lion Throne exhibition room

8. Colonial period (1885-1948) and the Period after Gaining Independence (1948-1988)

9. Our Leaders exhibition room

10. Presidents' Gifts exhibition room

11. Union of Myanmar Nationalities' Culture exhibition room

12. Art Galleries

13. Performing Arts exhibition room

14. Myanmar Art and Crafts exhibition room

15. ASEAN exhibition room

16. Children Discovery exhibition room

17. Special exhibition room

Although the National Museum (Nay Pyi Taw) has been under construction since 2010, it is not yet finished owing to the budget constraints. Thus, it has to be constructed and its exhibits are displayed portion by portion. For the first phase, 
Building (A) and Building (B) were opened in the 2014-2015 fiscal year. Building (C) and Building (D) will be finished in the 2015-2016 fiscal year as the second phase, and the last phase will be Building (E) in the 2016-2017 fiscal year.

\section{Exhibition at National Museum (Nay Pyi Taw)}

As the National Museum (Nay Pyi Taw) is a national-level museum, artifacts that represent the historical sequence of the successive period, arts and crafts cultural heritage, and our sovereignty are to be exhibited in the 17 exhibition rooms.

- For the first phase, the six rooms of Building (B) display the following six exhibition rooms: (1) B1- Primate and Fossils exhibition room; (2) B2- Prehistoric Period exhibition room; (3) B3- Art Gallery; (4) B4- Myanmar Performing Arts exhibition room; (5) B5- Protohistoric Period (second century BC to tenth century AD) exhibition room; and (6) B6- Historic Period of eleventh to fourteenth century AD exhibition room.

- In Building (C), there are four exhibition rooms: (1) C1- Historic Period of fourteenth to seventeenth century AD exhibition room; (2) C2, C3- Historic Period of eighteenth to nineteenth century AD exhibition room; (3) C4- Lion Throne exhibition room; (4) C5- Colonial Period (1885-1948) and the Period after gaining Independence (1948-1988).

- The following four exhibition rooms will be housed in Building (D): (1) D1Myanmar Art and Crafts exhibition room; (2) D2- ASEAN exhibition room; (3) D3- Children Discovery exhibition room; and (4) D4- Special exhibition room

- And Building (E) will showcase: (1) E1- Our Leaders exhibition room; (2) E2Presidents' Gifts exhibition room; (3) E3, E4- Union of Myanmar Nationalities' Culture exhibition room.

\subsection{Room B1 - Primate and Fossils Exhibition Room (Fig. 4)}

Primate fossils found in Myanmar will be displayed as the centerpiece. Scholars claim that the Pondaung primates are 40 million years old, which is 3 million years to 7 million years older than those found in Fayum, which are 33 million years old. It is pointed out that Myanmar is origin of human beings, which is something for the country to be proud of. In this exhibition room, the fossils of animals, feces, plants, and leaves are displayed. Besides, petrified wood of nearly $100 \mathrm{ft}$ long is displayed as the centerpiece 


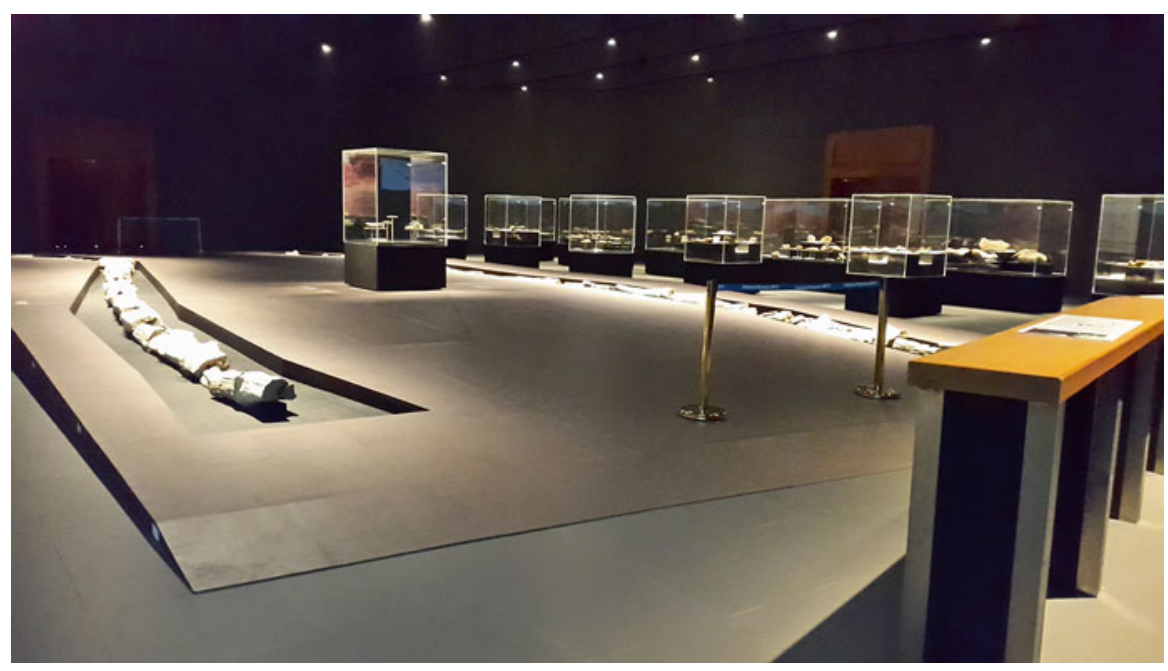

Fig. 4 Primate and fossils exhibition room

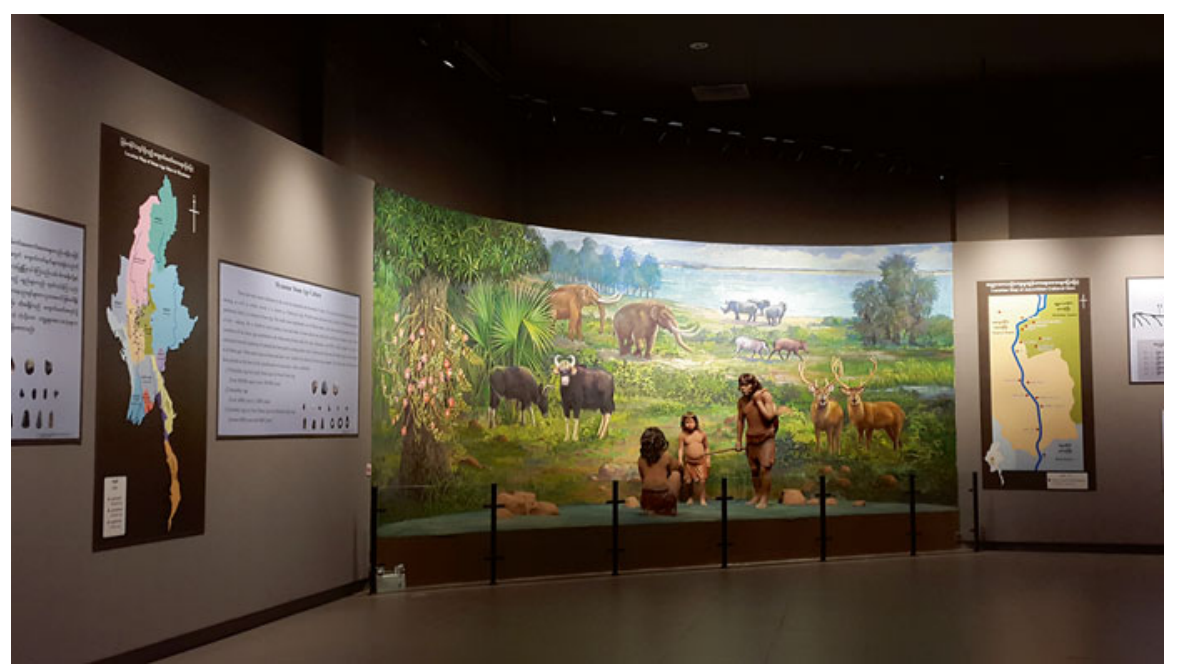

Fig. 5 Prehistoric period exhibition room

\subsection{Room B2 - Prehistoric Period exhibition room (Fig. 5)}

The prehistoric period comprises the Stone Age, Bronze Age, and Iron Age. Thus, in the Prehistoric Period exhibition room, an excavated Bronze Age site is created like a real one in the center of the room. A handrail is made to walk around the site. Stone implements $(5,000,000-4,000$ BP), bronze implements (4,000-3,000 BP), and the iron implements $(3,000 \mathrm{BP})$ found in Myanmar are also displayed in 


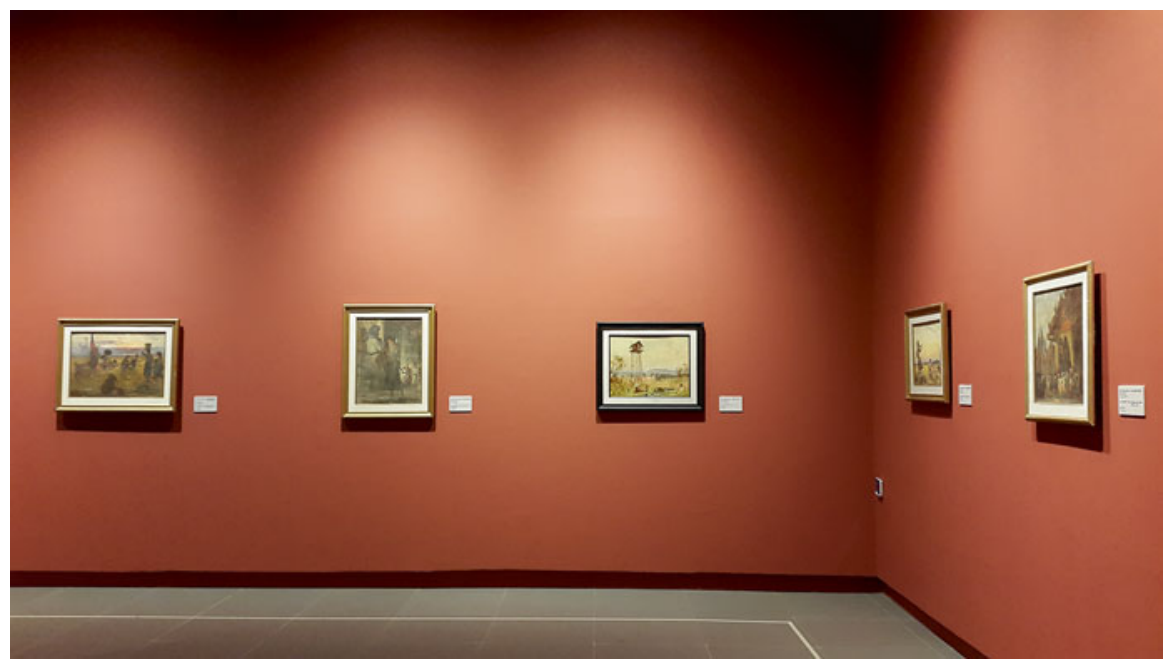

Fig. 6 Art gallery

the showcases. Besides, the Padalin cave in which there are mural paintings of the Neolithic Stone Age was made as a real-size model including models of Stone Age men drawing mural paintings, making fire, and making stone implements.

\subsection{Room B3-Art Gallery (Fig. 6)}

We show the history of Myanmar's paintings, mural paintings of the successive periods, Neolithic Stone Age mural paintings, mural paintings of the eleventh century $\mathrm{AD}$ to nineteenth century $\mathrm{AD}$, paper parchment paintings of the nineteenth century $\mathrm{AD}$, and contemporary art.

\subsection{Room B4- Performing Arts Exhibition Room (Fig. 7)}

Fine arts comprise an important factor for a country. Every country has its own fine arts and it is necessary to maintain them so that they do not deteriorate and they need to be showcased as precious items. The performing arts is an important component of the fine arts. The National Museum (Nay Pyi Taw) has thus planned to have a Myanmar Performing Arts exhibition room in Room B4. In this room, the history of Myanmar performing arts, Myanmar grand orchestra, Myanmar marionettes, and traditional instruments of nationalities are exhibited by using miniature models and figures. 


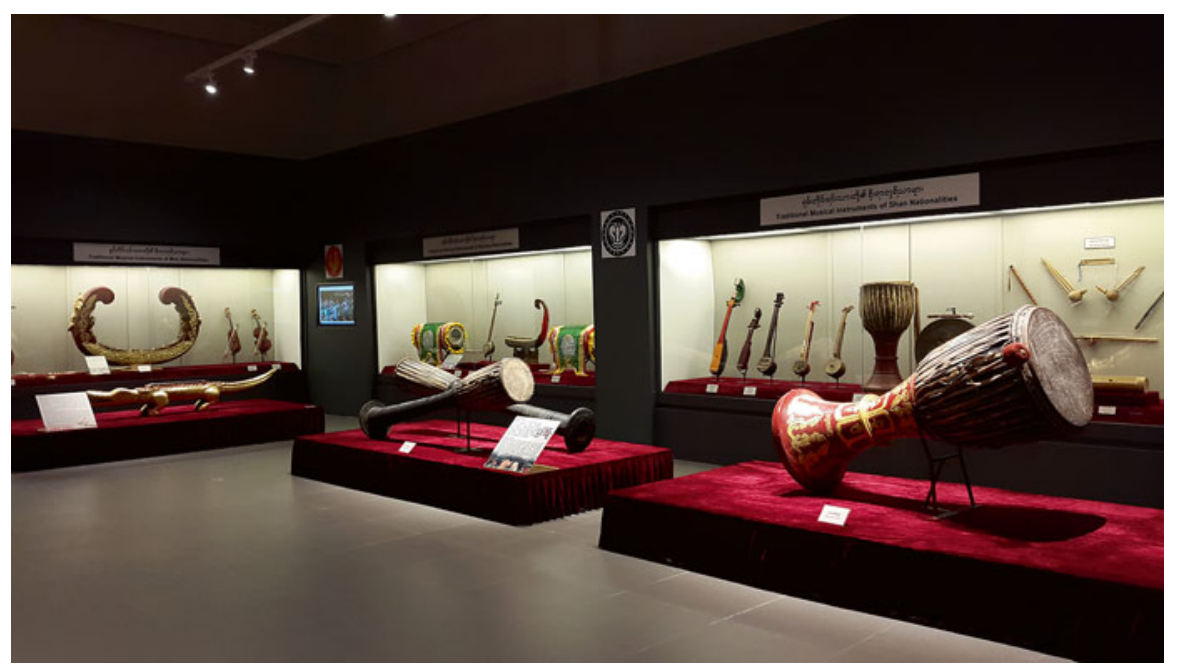

Fig. 7 Performing arts exhibition room

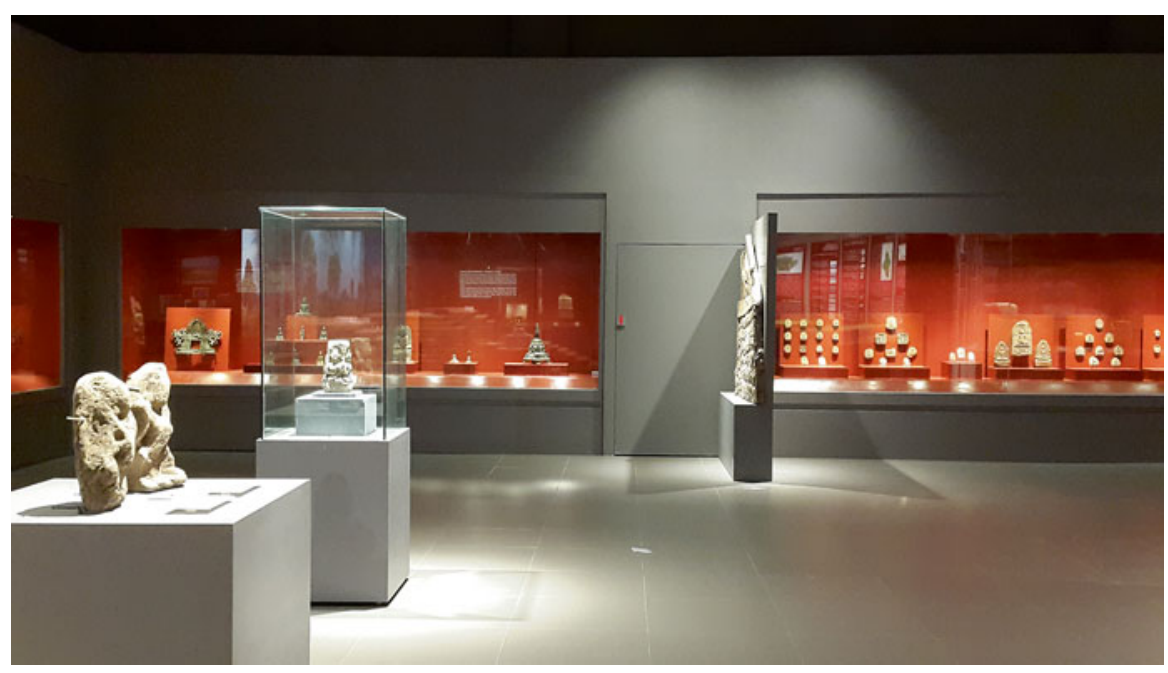

Fig. 8 Protohistoric period (second century BC to tenth century AD) exhibition room

\subsection{Room B5 - Protohistoric Period (Second Century BC to Tenth Century AD) Exhibition Room (Fig. 8)}

It consists of information about the Pyu civilization, which flourished between second century $\mathrm{BC}$ to tenth century $\mathrm{AD}$ (i.e., the protohistoric period). Here, miniature models of buildings, ornaments, Buddha statues, Brahmanism statues, burial urns, household utensils made of bronze and terracotta, and iron and coins of the Pyu period are displayed. 


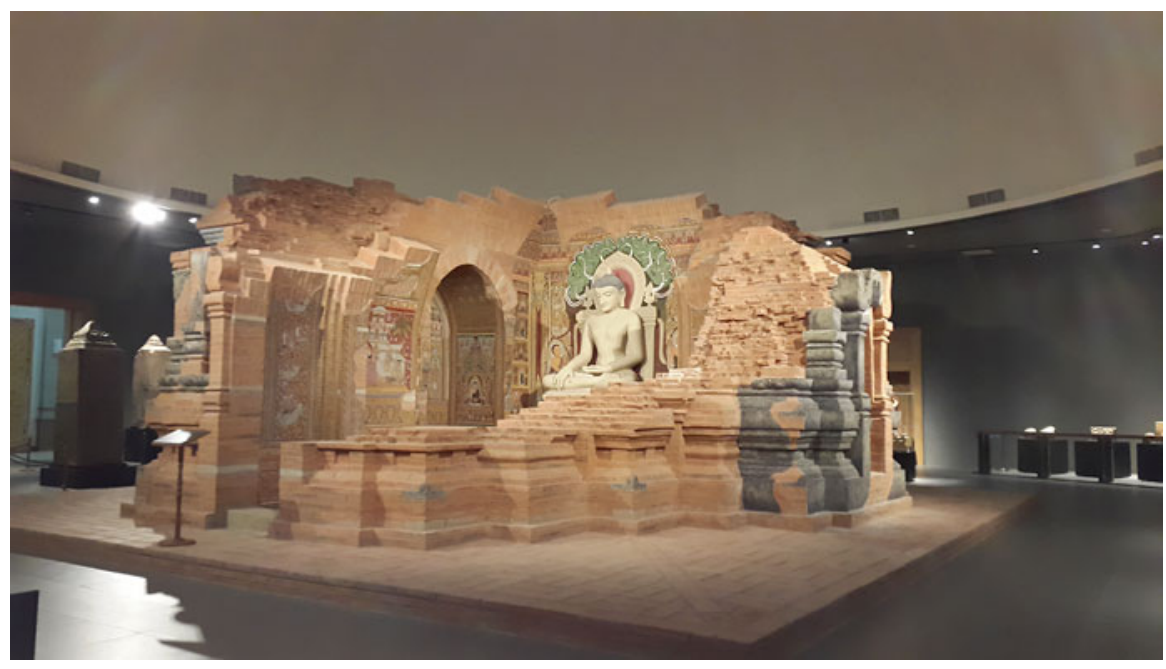

Fig. 9 Historic period of eleventh to fourteenth century AD exhibition room

\subsection{Room B6 - Historic Period of Eleventh to Fourteenth Century AD Exhibition Room (Fig. 9)}

Between the eleventh century AD and fourteenth century AD, civilization flourished vigorously in Bagan and it is famous as a Myanmar Cultural Heritage region situated in the central part of Myanmar. Artifacts of architecture, arts and crafts, literature, and religion of the Bagan period are displayed in this exhibition room. Besides, a section model of a Bagan-period temple has been constructed to display Bagan-period art and architecture.

\subsection{Room C1 - Historic Period of Fourteenth to Seventeenth Century AD Exhibition Room}

In Building (C), Room $\mathrm{C} 1$ is the Historic Period of the fourteenth to seventeenth century AD (Pinya, Innwa, Hamthawaddy, and Mrauk-U period) exhibition room. The culture of Myanmar's historic period commenced in the Bagan period (eleventh century AD) and successively developed into the Pinya, Innwa, Hamthawaddy, and Mrauk-U periods (fourteenth to seventeenth century AD). In this exhibition room, a miniature model of the palace of King Bayintnaung who was the founder of the Second Myanmar Kingdom in 1566 AD will be displayed. Rare antiquities such as ornaments, utensils, and other accessories of these periods will also be displayed. 


\subsection{Room C2, C3 - Historic Period of Eighteenth to Nineteenth Century AD Exhibition Room}

The Konbaung-Yadanapon Period exhibition room will display aspects of the Third Myanmar Kingdom founded by King AlaungPhaya. Moreover, a miniature model of the Yadanapon Palace built by the second-last king of Myanmar, King Mindon, will be exhibited. The Konbaung-Yadanapon Dynasty is the last dynasty of Myanmar (1752-1885 AD). Costumes, utensils, ornaments, and documents of these periods will be exhibited in this exhibition room.

\subsection{Room C4- Lion Throne Exhibition Room}

A replica of the Royal Lion Throne will be displayed altogether with royal regalia. Although it is a replica, the actual motive behind the display is to show Myanmar's sovereignty, which has existed for a long time. The real Lion Throne was used by Myanmar kings to sit on when the Royal Court was held in the palace.

\subsection{Room C5-Colonial Period (1885-1948) and the Period After Gaining Independence (1948-1988)}

Owing to annexation by the British government, Myanmar was a colonial country. In this exhibition room, evidence and documents of attempting to gain independence during the colonial period and documents of the period after gaining Independence (1948-1988) will be displayed.

\subsection{Room D1-Myanmar Art and Crafts Exhibition Room}

Myanmar possess ten traditional art and craft such as blacksmith, goldsmith, art of bronze casting, art of decorating with stucco, craft of a mason, art of carving, art of stone sculpture, craft of a turner, art of painting, art of making lacquer ware. In this exhibition room, not only the ten traditional art and crafts but also other Myanmar traditional crafts; making gold leaf, tapestry, weaving and glass mosaic will be displayed together with the explanation. 


\subsection{Room D2- ASEAN Exhibition Room}

As Myanmar is a member of the Association of South East Asia Nations (ASEAN), we need to praise about ASEAN and should educate and give more knowledge to the people about the emblem and objectives of ASEAN, National flowers, National flags and National land marks of the ASEAN member countries.

\subsection{Room D3- Children Discovery Exhibition Room}

The children are the most important in the building Nation because of the future generation. It is necessary to fulfill and promote their curiosity, knowledge and learning ability. Hence, National Museum (Nay Pyi Taw) creates a special children exhibition room including audio- visual about our Universe and our World, 3D painting of the evolution of flora and fauna, life size models of evolution of man, miniature models of the ancient settlement pattern, the costumes of our Nationalities and our neighboring countries, the explanation and scenery of 12 Myanmar traditional festivals, the Myanmar traditional weaving, excavation and recording methods for the antiquities. Moreover, the children can participate in "the build the city project" by using the puzzle blocks.

\subsection{Room D4- Special Exhibition Room}

This exhibition room is actually a temporary exhibition room and can exhibit according to the title or subject or objects quarterly or yearly.

\subsection{Room E1- Our Leaders Exhibition Room}

In this exhibition room, our National Leaders such as General Aung San, Presidents and Prime Ministers of the successive period will be displayed as the historical evidences.

\subsection{Room E2- Presidents' Gifts Exhibition Room}

When the Presidents of the Republic of the Union of Myanmar visit to abroad or the foreign diplomats visit to Myanmar, the gifts are always presented as the good well presents. Those presents are precious and artistic and people can have the great chance to see them and can study about the other foreign countries' culture. 


\subsection{Room E3, E4- Union of Myanmar Nationalities' Culture Exhibition Room}

As the Union of the Republic of Myanmar has various nationalities, they live intimately in our country. Hence, the National Museum (Nay Pyi Taw) has a detailed plan for display on nationalities in rooms E 3 and E4. The display will comprise their lifestyle, tradition, culture, religion, literature, and habits. Thus, traditional instruments, implements, ornaments, and clothes of the nationalities will be showcased. Moreover, their traditions and festivals will be displayed by using miniature models and figures.

According to the exhibition rooms, there are a great variety of display objects made of different materials such as gold, silver, bronze, iron, stone, terracotta, glaze, porcelain, animal bone, wood, bamboo, cane, textile, paper, and fiberglass.

There are altogether 12,975 display objects collected as follows:

\begin{tabular}{l|r}
\hline Stone objects & 6,128 \\
\hline Bronze objects & 2,457 \\
\hline Iron objects & 190 \\
\hline Gold objects & 43 \\
\hline Silver objects & 706 \\
\hline Terracotta objects & 1,470 \\
\hline Glazed objects & 145 \\
\hline Porcelain objects & 38 \\
\hline Glass objects & 14 \\
\hline Machinery & 110 \\
\hline Lead objects & 29 \\
\hline Animal objects & 43 \\
\hline Wooden objects & 420 \\
\hline Lacquer, bamboo, cane objects & 245 \\
\hline Textiles & 526 \\
\hline Paper objects & 175 \\
\hline Paintings & 369 \\
\hline Seals & 135 \\
\hline Replicas & 52 \\
\hline Other & 80 \\
\hline Total & 12,945
\end{tabular}

The National Museum (Nay Pyi Taw) has been collecting display objects although it has not yet opened totally (Fig. 10). 

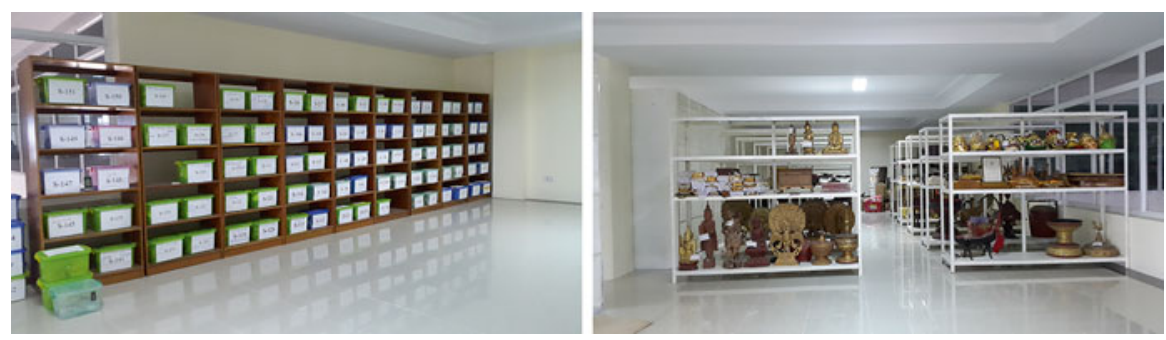

Fig. 10 Storerooms at the National Museum (Nay Pyi Taw)

\section{Documentation at National Museum (Nay Pyi Taw)}

When the display objects arrive at the Museum, they have to be entered in the "Entry record" including identification such as gift, purchase, loan, or transfer with the signature, name, and address of the depositor. And then it is necessary to give each object an accession number (Crafts Museum India 2004; ICCROM). At present, a tripartite or trinomial system is being used. In this system, the first number is usually the year the accession was made. The second number is the lot number that is designated by type of material. The third number is the object number accessioned in a particular lot. For example, if a bronze object is accessioned in 2013 and its serial number in lot is 100 , the accession number is $2013,1,100$.

The lot numbers are given together with the materials as follows:

1. Stone objects

2. Bronze objects

3. Iron objects

4. Gold objects

5. Silver objects

6. Terracotta objects

7. Glazed objects

8. Porcelain objects

9. Glass objects

10. Machinery

11. Lead objects

12. Animal objects

13. Wooden objects

14. Lacquer, bamboo, and cane objects

15. Textiles

16. Paper objects

17. Paintings

18. Seals

19. Replicas

20. Other 
After that, proportions and weight are measured, photographs are taken, and then index cards are filled in and attached to the objects. Entries are made in the registration record and the museum objects database. When a display object is positioned, a location and movement record is necessary. Whenever the object is moved, this is recorded and so it is easy to find the object. When any object is borrowed or lent, a "Loan record (incoming)" or "Loan record (outgoing)" is filled in. Although the National Museum (Nay Pyi Taw) has not yet opened totally, the collected display objects have been lent to foreign museums such as the Quanxi Museum for Nationalities, China in 2011, the Metropolitan Museum of Art in New York, United States of America, in 2014, and the Asia Society in New York, United States of America, in 2015.

\section{Conservation at National Museum (Nay Pyi Taw)}

The most important step in the conservation process is to document the existing condition of the object. Documentation is done for every object that has been brought into the conservation laboratory prior to any treatment. In this document, the physical condition such as any cracks, disfigurement to the object, any sign of damage or wear, addition and losses, previous restoration, color change, insect damage, and bio deterioration are mentioned. And then the method of treatment is documented to allow the conservators to monitor and assess the effectiveness of the treatment in the future. Moreover, reconstruction and restoration works are also completely documented and the administrative details are recorded. When the treatment is completed, the condition of the object is documented again for comparison with its pretreatment condition. The National Museum (Nay Pyi Taw) is using both textual documentation and visual documentation. For textual documentation, the checklist style of documentation is used and digital photos are used for visual documentation. And then both are installed as a computer database (Moore 2000).

A major objective of all conservation treatments is to increase the chemical stability of the object being treated. Cleaning often forms an important part of the stabilizing process. This is because dirt on an object can be a potent source of deterioration (as, for example, when chloride salts set up corrosion reactions on bronze, or moulds grow on organic materials like paper or textiles). At other times, cleaning may be a necessary preliminary to a further treatment (Conservation Unit Museums and Galleries Commission 1992). Therefore, cleaning the dirt is the main conservation work in the National Museum (Nay Pyi Taw) (The National Museum (Nay Pyi Taw) 2012).

"Dirt" can be classified into two types:

1. Foreign matter that is not part of the original object

(Examples: soot, grease, stains, adhesives, and fillings from previous treatment)

2. Products of alteration of the original materials 


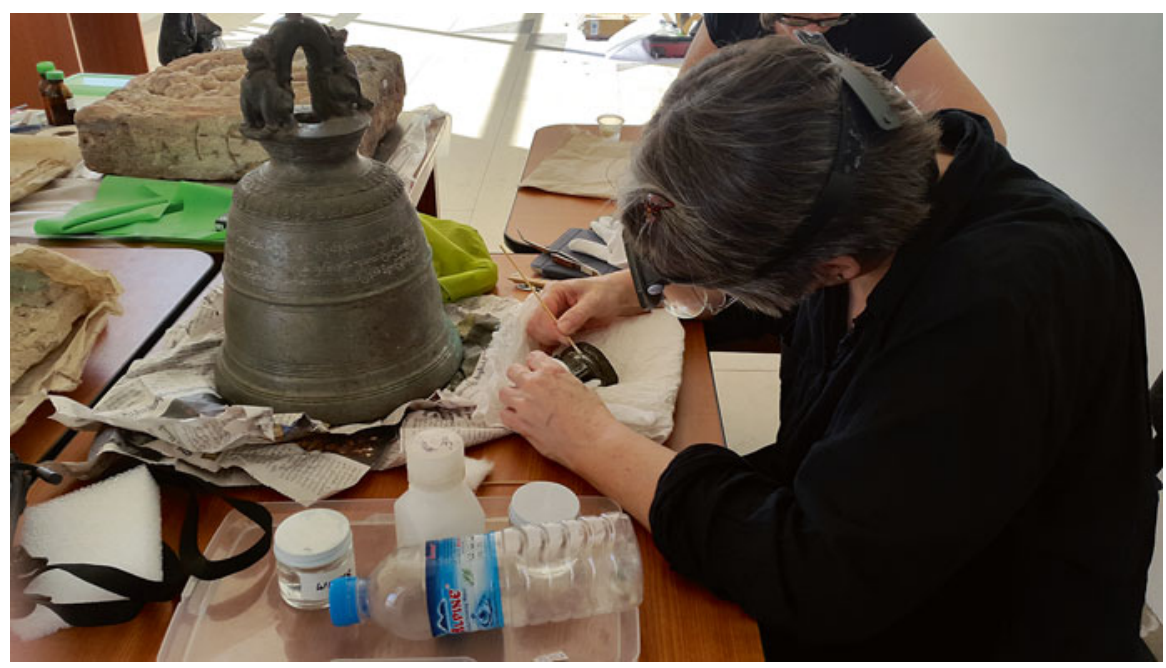

Fig. 11 Conservation of bronze objects

(Examples: metal corrosion products and decayed timber or stone)

Dust (foreign matter) is commonly an amazing mixture of fragments of human skin, textile fibers, carbon particles (soot), and grease from unburned hydrocarbon fuels, from cooking and from the skin of people and animals. There are many salts in dust, for example, sodium chloride and sharp gritty silica crystals are often present. In this chemical mixture are the spores of countless moulds and fungi and micro-organisms that are equally likely to attack objects made of organic material. Much of this dirt is hygroscopic (water-attracting) and this tendency can encourage the growth of moulds and increase the corrosiveness of salts. So even dust is damaging although perhaps only slowly. If the dust is a product of alteration of part of an object, some of the object itself will be taken away when removing the dust. For instant, when the tarnish on a silver object is cleaned away, not only the sulfur atoms that are foreign matter but also some silver atoms originally positioned by the silversmith.

Conservation has to be done according to the type of object. Object types can be classified as (1) metal objects, (2) organic objects, and (3) inorganic objects.

1. Metal objects include bronze, gold, silver, and lead.

- For bronze objects, both physical and chemical cleaning methods are used. In the physical method, corrosion products are removed by using simple mechanical tools such as a pin, scalpel, chisel, hammer, and motor drive vibrator. And then the final rub is done by using fine emery paper to bring out the inner patina. The chemical cleaning method is where the bronze object is immersed in $5 \%$ citric acid $\left(\mathrm{T}-60-80^{\circ} \mathrm{C}\right)$ and washed with distilled water and then dried (Fig. 11). 
- Gold objects are soaked in $2 \%$ caustic soda solution to remove the organic remains. Normally, corrosion does not take place on gold objects and they can be cleaned by using distilled water.

- Silver objects are cleaned by immersing in $10 \%$ formic acid for an hour and washed with distilled water and dried.

- The incrustation on lead objects can be cleaned by using $10 \%$ acetic acid by means of a brush.

- For iron objects, rust can be removed by boiling repeatedly in $10 \%$ caustic soda for three weeks. Lumps of lime incrustation can be removed by dilute nitric acid before treatment with caustic soda.

2. Organic objects include wood, palm leaf, paper, bamboo, lacquer, textile, bone and ivory, and feather and leather.

- Wooden objects are easily affected by insects. Insect-attacked wooden objects should be fumigated in the laboratory but this cannot be done in the National Museum (Nay Pyi Taw) because there is no fumigation chamber. Thus, cleaning can be only done by using rectified spirit.

- For palm leaf manuscripts, the dust on the leaves is cleaned with a brush, the leaves are cleaned with rectified spirit, and 5\% lemongrass oil in rectified spirit is then applied.

- Paper objects can be decayed by moisture, dust, insects, faulty storage, etc. Paper objects should be kept at $60 \%$ RH. If it is not, paper will absorb the moisture and acidity in the paper will form acid and then the paper will decay. In the storage room of the National Museum (Nay Pyi Taw), the relative humidity is adjusted to about $60 \%$.

- Bone and ivory are cleaned by using rectified spirit.

- Feather and leather are kept under a condition of $60 \%$ RH and a temperature is $20^{\circ}$.

3. Inorganic objects such as clay objects and stone objects can be cleaned with a brush first. Baked clay objects can be soaked in water repeatedly to clean them. Stains of oil, wax, or paint on stone objects can be cleaned by acetone and a $5 \%$ solution of ammonium hydroxide is used to remove the algae (Fig. 12).

The collected display objects in the National Museum (Nay Pyi Taw) are just cleaned and consolidated; coating is rarely done so as not harm the aesthetic beauty of the object.

\section{Conclusion}

In fact, Myanmar has a long history of culture and a great many cultural heritages both tangible and intangible. The National Museum (Nay Pyi Taw) is trying to reflect this precious Myanmar cultural heritage and planning to collect and display the objects in the best and most interesting museum in the world. Hence, it is also 


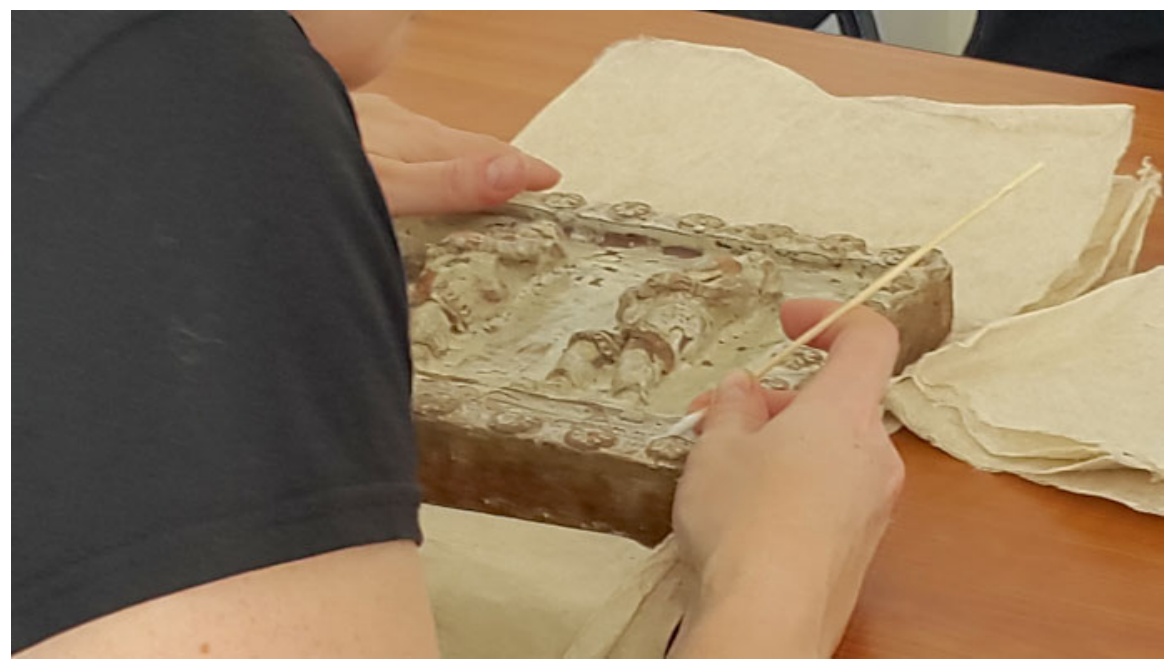

Fig. 12 Conservation of clay objects

important not only to do conservation and documentation works but also to exhibit by using modern techniques. The National Museum (Nay Pyi Taw) is still under construction and two buildings including six exhibition rooms were opened on 15 July 2015 as the first phase and the remaining buildings will be opened phase by phase in the coming years. For the national-level exhibition rooms, display objects are being collected. Some of these are excavated from ancient sites and some are collected by donation, exchange, and given as awards. Each and every display object arriving at the National Museum (Nay Pyi Taw) is systematically documented. These museum display objects need to be preserved and conserved in a conservation laboratory with the full equipment. However, the display objects are being conserved by using simple chemicals and ordinary equipment. Therefore, the National Museum (Nay Pyi Taw) has been undertaking the documentation, conservation, and exhibition process voluntarily.

Notes This paper was first presented in February 2015 at the international symposium "New Horizons for Asian Museums and Museology." As the National Museum (Nay Pyi Taw) was opened in July 2015 (the first phase), the contents of the paper has been updated.

Present affiliation of the author: Cultural Museum (Taunggyi), Myanmar

Open Access This chapter is distributed under the terms of the Creative Commons AttributionNonCommercial 4.0 International License (http://creativecommons.org/licenses/by-nc/4.0/), which permits any noncommercial use, duplication, adaptation, distribution and reproduction in any medium or format, as long as you give appropriate credit to the original author(s) and the source, provide a link to the Creative Commons license and indicate if changes were made.

The images or other third party material in this chapter are included in the work's Creative Commons license, unless indicated otherwise in the credit line; if such material is not included in the work's Creative Commons license and the respective action is not permitted by statutory regulation, users will need to obtain permission from the license holder to duplicate, adapt or reproduce the material. 


\section{References}

Conservation Unit Museums and Galleries Commission. 1992. The science for conservators series: Volume-2 cleaning. London/New York: Taylor \& Francis.

Crafts Museum, India. 2004. Accession register. New Delhi: Naveen Printers.

ICCROM. Documentation of museum collection, UNESCO, ICCROM, and EPA. http://www.epaprema-net/documents/ressources/manual.htm. Accessed 22 Apr 2011.

Moore, Michelle. 2000. Conservation documentation and the implications of digitization. UK: Institute of Archaeology.

The National Museum (Naypyitaw). 2012. Manual for conservators. (Internal communication). 


\title{
Conservation Science Research at the Museum: Development of Carbon Dioxide Treatment for Museum Collection
}

\author{
Shingo Hidaka
}

\begin{abstract}
The development of an enclosure-type insecticidal treatment for ethnographic/folklore artifacts using carbon dioxide is described. After the successful installation of the system, the technique was applied on a larger scale using a special enclosure-type bag (11.5 $\mathrm{m}$ in length, $10 \mathrm{~m}$ in width, and $2 \mathrm{~m}$ in height). Since one of the preconditions for development of the system was that the treatment procedures could be performed by museum staff, close attention was paid to worker safety. Other challenges faced were to: minimize the decrease in humidity inside the bag when carbon dioxide is supplied; achieve a uniform distribution of carbon dioxide concentration in a large-scale treatment facility; and establish supplementary methods for killing insects that resist by carbon dioxide treatment (e.g. longicorn beetles).
\end{abstract}

\section{Introduction}

Methyl bromide was widely used in Japan for the insecticidal treatment of cultural properties in the past, but it is no longer permitted for use because of a resolution made in the Meeting of the Parties to the Montreal Protocol to totally ban the use of methyl bromide at the end of 2004. Thus, there is urgent need to accelerate the practical application and implementation of a new insecticidal treatment method alternative to the method using methyl bromide for preserving cultural properties. In this regard, research has been conducted on the insecticidal treatment method using carbon dioxide, a gas harmless to people and the environment, and the low-oxygen treatment method using an inert gas such as nitrogen, in an effort to establish a method alternative to the fumigation method using methyl bromide preparations that was commonly performed in Japan previously. There are a number of reports introducing actual cases of using these new methods at museums.

\footnotetext{
S. Hidaka $(\bowtie)$

National Museum of Ethnology, Senri Expo Park, Suita, Osaka 565-8511, Japan

e-mail: s-hidaka@idc.minpaku.ac.jp 
The author has been working at the Gangoji Institute for Research of Cultural Property since 1994, and specializes in the development of technologies for the preservation of primarily folklore artifacts. Folklore artifacts are made of plant materials, most often wood, so these cultural properties are prone to insect damage. Thus, insecticidal treatment is an important process required for preserving folklore artifacts. In view of this, the author examined methods of insecticidal treatment for mainly folklore artifacts that can replace the method using methyl bromide. It should be noted that the gas fumigation method was excluded from examination in order to align with the globally growing concerns for people and the environment (Strang and Kigawa 2011; Kigawa and Strang 2011).

Since there are huge numbers of folklore artifacts subject to insecticidal treatment, the treatment must be inexpensive to perform, be applicable to objects of various sizes and shapes, and allow mass processing of artifacts. The author developed an enclosure-type insecticidal treatment system using carbon dioxide, which satisfies all these requirements, and put it into practical use at the National Museum of Ethnology (Minpaku).

This paper introduces the case of insecticidal treatment of folklore artifacts using carbon dioxide, a method developed and practiced by the author et al.

\section{Development of an Enclosure-Type Insecticidal Treatment System Using Carbon Dioxide}

The author began experimental insecticidal treatments using carbon dioxide in earnest in 2000. To develop the treatment system, experiments were conducted four times. The scale of the experiments was determined in accordance with the size and quantity of the target folklore artifacts in order to accurately simulate the actual processing conditions. The first, second, and fourth experiment sessions were held at the Gangoji Institute for Research of Cultural Property (Fig. 1), and the third experiment session was conducted in the repository at the Japan Footwear Museum, courtesy of the Museum.

The sheets (carbon dioxide permeability: $4 \mathrm{ml} /\left(\mathrm{m}^{2}\right.$.days.atm)) used for the experiments were barrier cloth sheets laminated with a layer of ethylene-vinyl alcohol copolymer $(\mathrm{EVOH})$ that combines the gas barrier properties between layers of polyethylene. In passing, polyethylene sheets commonly used for conventional gas fumigation are unsuitable because of their carbon dioxide permeability. The following shows the scale of the insecticidal treatment facility used in each experiment session.

First experiment session:

Second experiment session:

Third experiment session:

Fourth experiment session:
$3 \mathrm{~m} \times 3 \mathrm{~m} \times 2 \mathrm{~m}$ (height)

$3 \mathrm{~m} \times 3 \mathrm{~m} \times 2 \mathrm{~m}$ (height)

$2.5 \mathrm{~m} \times 2 \mathrm{~m} \times 1.5 \mathrm{~m}$ (height)

$1.5 \mathrm{~m} \times 1.5 \mathrm{~m} \times 1.5 \mathrm{~m}$ (height) (fastener bag)

$5 \mathrm{~m} \times 3 \mathrm{~m} \times 2 \mathrm{~m}$ (height) 


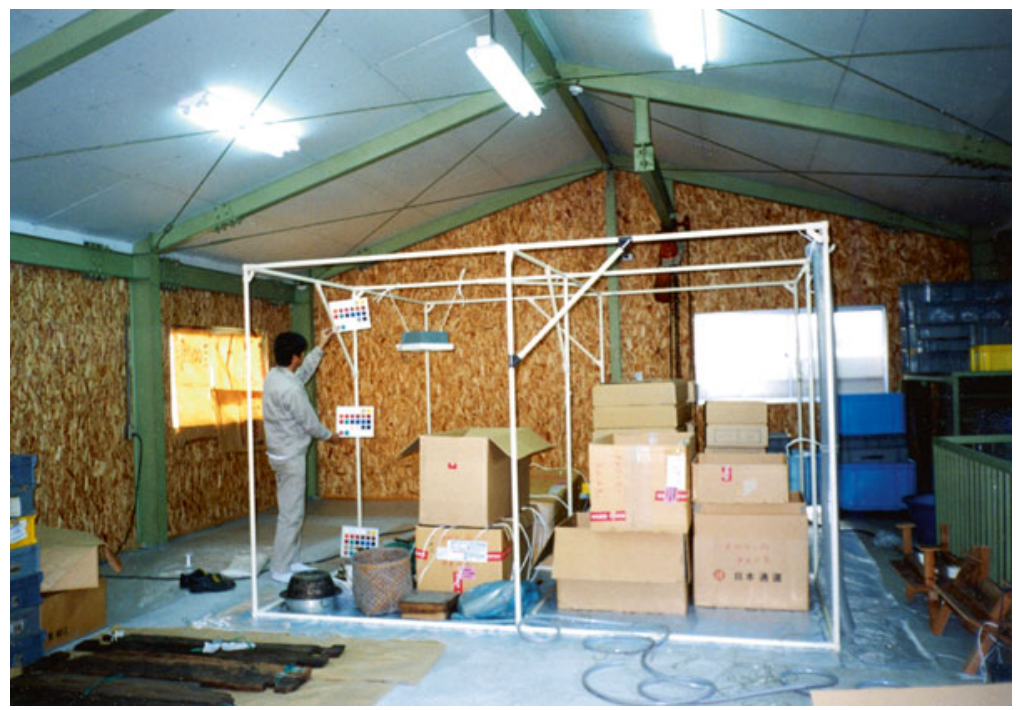

Fig. 1 Experimenting an enclosure-type insecticidal treatment system at the Gangoji Institute for Research of Cultural Property

These experiments were performed in order to confirm the setting of the carbon dioxide concentration in the initial treatment condition, adsorption of carbon dioxide by folklore artifacts, and effect on folklore artifact pigments. They also provided useful information pertaining to the process control necessary for the practical application of the method, such as air-tightness of the barrier cloth sheet, method of checking safety during processing, and cautions during the evacuation of gas. Consequently, the author was able to complete the instruction manual for insecticidal treatment using carbon dioxide.

\section{Development of Technologies Necessary for Applying the Insecticidal Treatment Method Using Carbon Dioxide at Museums}

After assuming a post at Minpaku in 2002, the author began working on the development of a system for applying the insecticidal treatment method using carbon dioxide that the procedures could be performed by museum staff. To prevent pest damage at Minpaku, the author introduced IPM (integrated pest management); examined methods of preventing insect damage to discover insect damage at the early stages and to perform insecticidal treatments; and ensured that these activities would link systematically with each other without causing isolation of individual activities (Sonoda 2007; Sonoda and Hidaka 2008, 2011). To this end, the author 


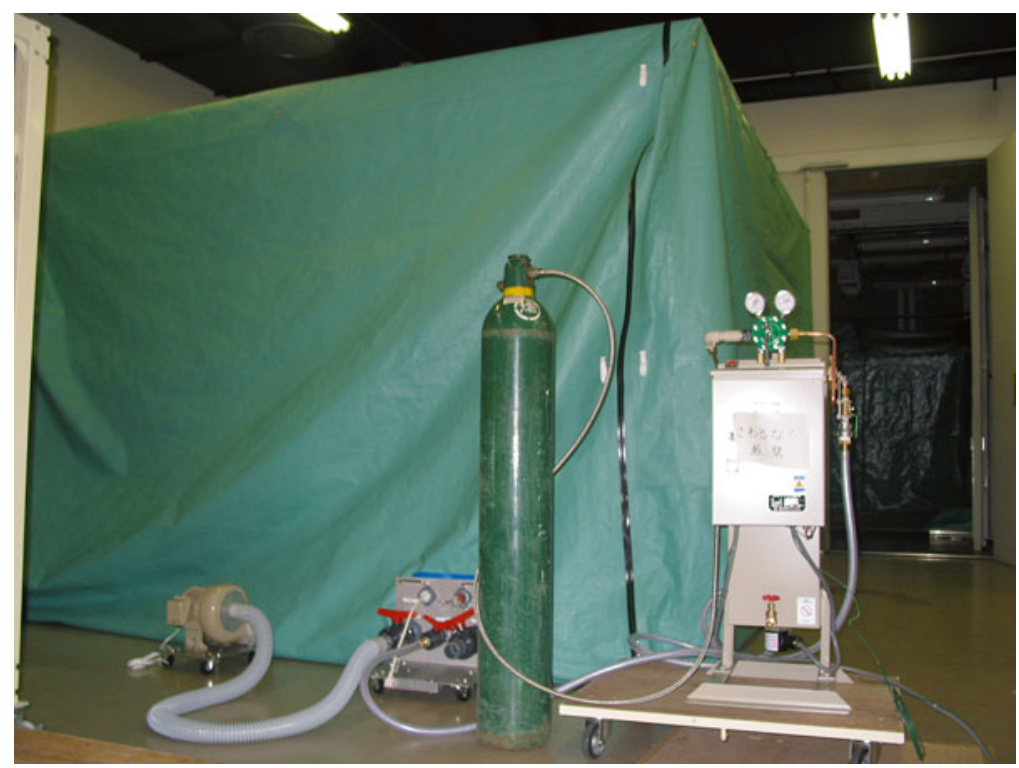

Fig. 2 Carbon dioxide treatment using a fastner bag

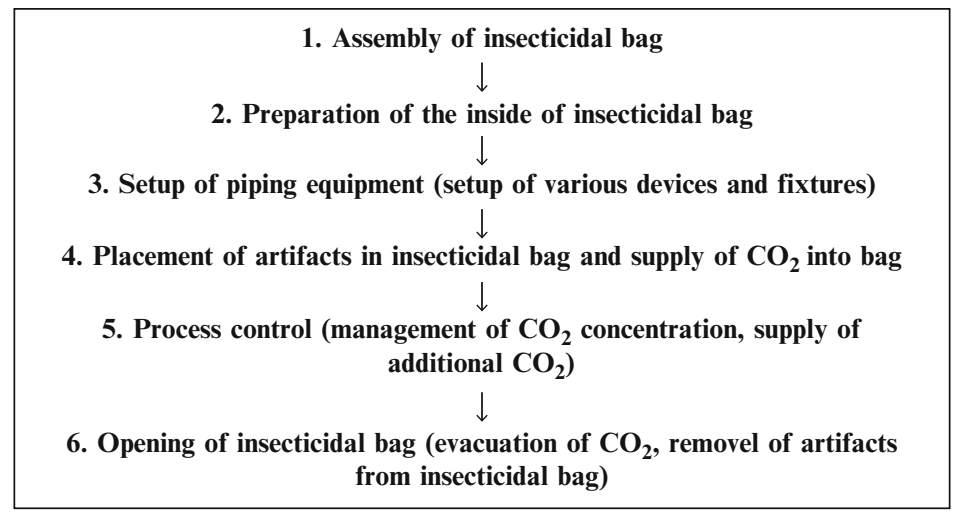

Fig. 3 Process flow of treatment using carbon dioxide

maximized the experience of successfully developing a carbon dioxide system that can be used for performing insecticidal treatments of a certain scale.

For the experiments that aimed at practical application of the insecticidal method, gas barrier cloth sheets were modified and a commercially available fastener bag $(1 \mathrm{~m}($ depth $) \times 1 \mathrm{~m}$ (width) $\times 1.5 \mathrm{~m}$ (height) $)$ was enlarged to a size measuring $4 \mathrm{~m}$ in depth, $4 \mathrm{~m}$ in width, and $2.5 \mathrm{~m}$ in height (Fig. 2). To enable the museum staff to perform the treatment, a manual was prepared, with special focus on providing safety precautions. Figure 3 shows the process flow chart created during the preparation of 


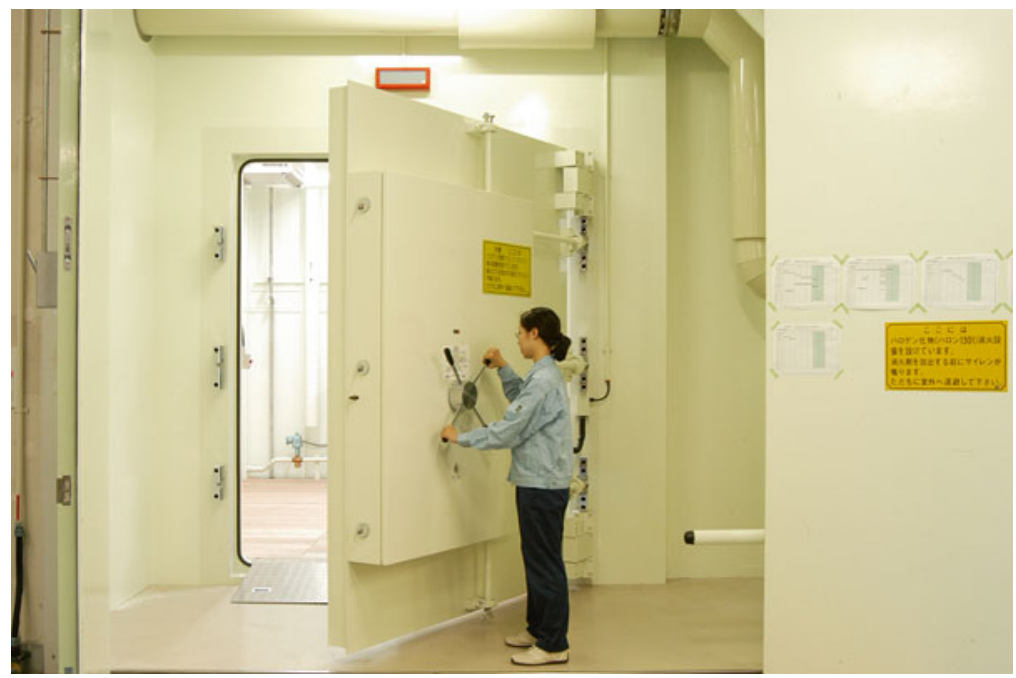

Fig. 4 Fumigation room capable of performing either gas fumigation, carbon dioxide treatment, or low-oxygen treatment

the instruction manual. In 2007, it was decided to modify the existing fumigation room $(5 \mathrm{~m}($ depth $) \times 4.3 \mathrm{~m}$ (width) $\times 3.6 \mathrm{~m}$ (height) $)($ Fig. 4$)$ and install a system capable of selectively performing gas fumigation using an ethylene oxide preparation, treatment using carbon dioxide, or low-oxygen treatment using nitrogen.

\section{Adaptability of the Insecticidal Treatment Method Using Carbon Dioxide in Large Fastener Bags}

After the successful installation of the system and a large fastener bag for insecticidal treatment using carbon dioxide at Minpaku, the author applied the technology to perform the treatment on a larger scale.

In 2013, the large tents (Fig. 5) in which large wooden boats and other items were stored were removed, and a multi-functional storage facility (Fig. 6) was constructed.

The multi-functional storage facility is equipped with a $\mathrm{CO}_{2}$-based/low-oxygen insecticidal treatment system and provided with a washing area (Fig. 7), so that it can be used to store wooden boats and also as a temporary storage site for cultural properties damaged by disaster. At the start of full-fledged operation of this facility at Minpaku, wooden boats were processed with the insecticidal treatment using carbon dioxide before storage. Using the permanently set up large fastener bag measuring $6.9 \mathrm{~m}$ in length, $2.8 \mathrm{~m}$ in width, and $2.2 \mathrm{~m}$ in height (Fig. 8), wooden boats were treated with carbon dioxide. The size of the permanently set up large fastener bag was determined in such a way that it would be large enough for $80 \%$ of the 


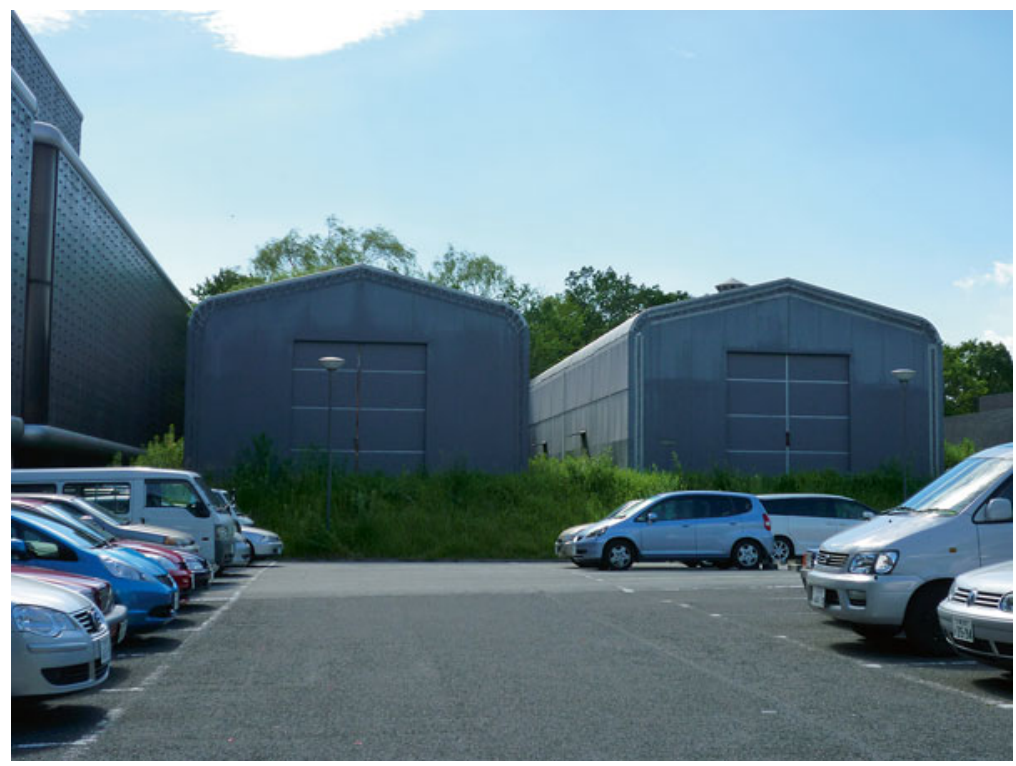

Fig. 5 Large tents storing wooden boats (before 2013)

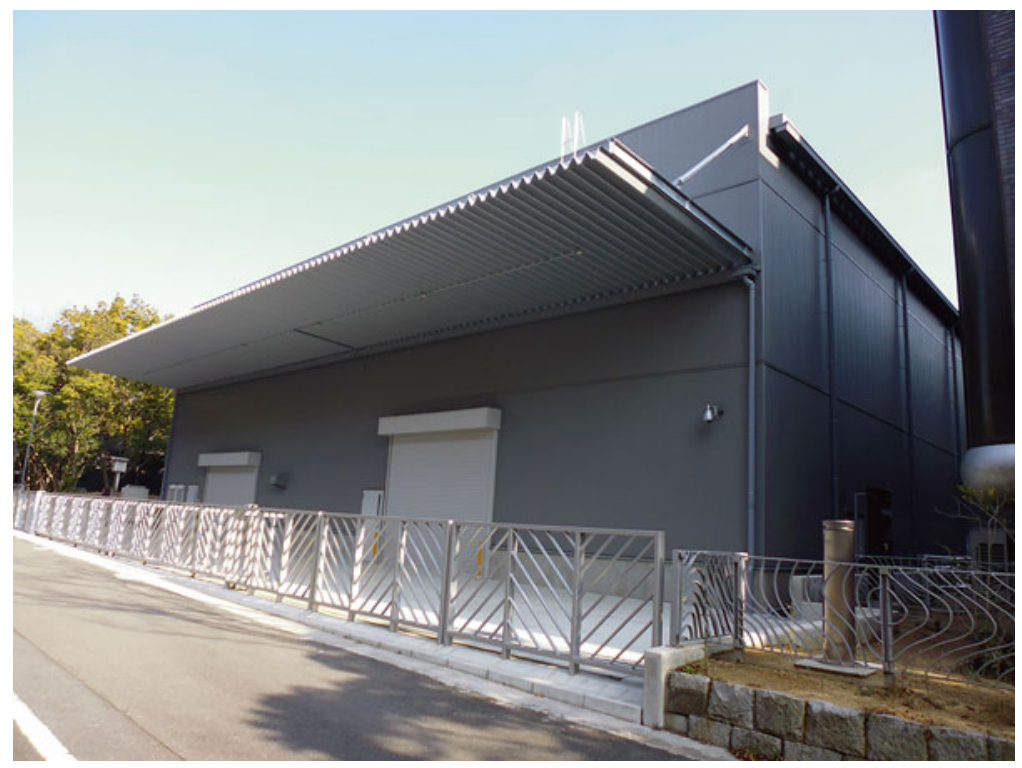

Fig. 6 Multi-functional storage facility storing wooden boats (after 2013) 


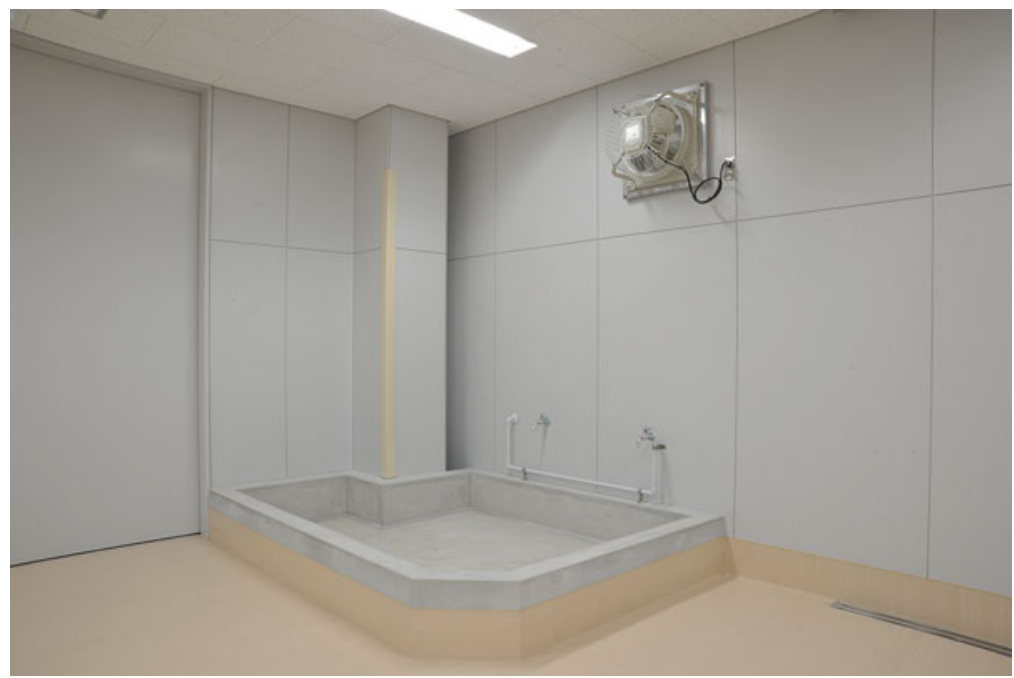

Fig. 7 Washing area

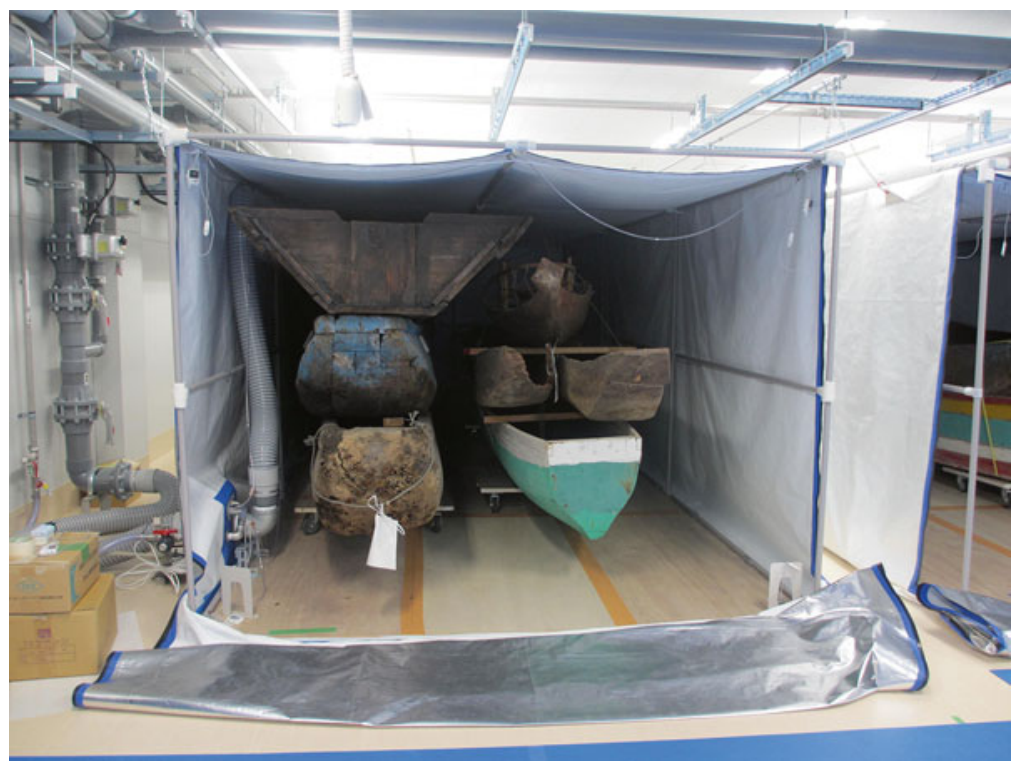

Fig. 8 Wooden boats treated with carbon dioxide in a permanently set up large fastener bag

wooden boats in storage. Large wooden boats that did not fit into this bag were treated with carbon dioxide in an enclosure-type insecticidal treatment bag measuring $11.5 \mathrm{~m}$ in length, $10 \mathrm{~m}$ in width, and $2 \mathrm{~m}$ in height (Fig. 9).

The data on actual insecticidal treatments using carbon dioxide are shown below. Figure 10 shows the concentration of carbon dioxide during the treatment in the 


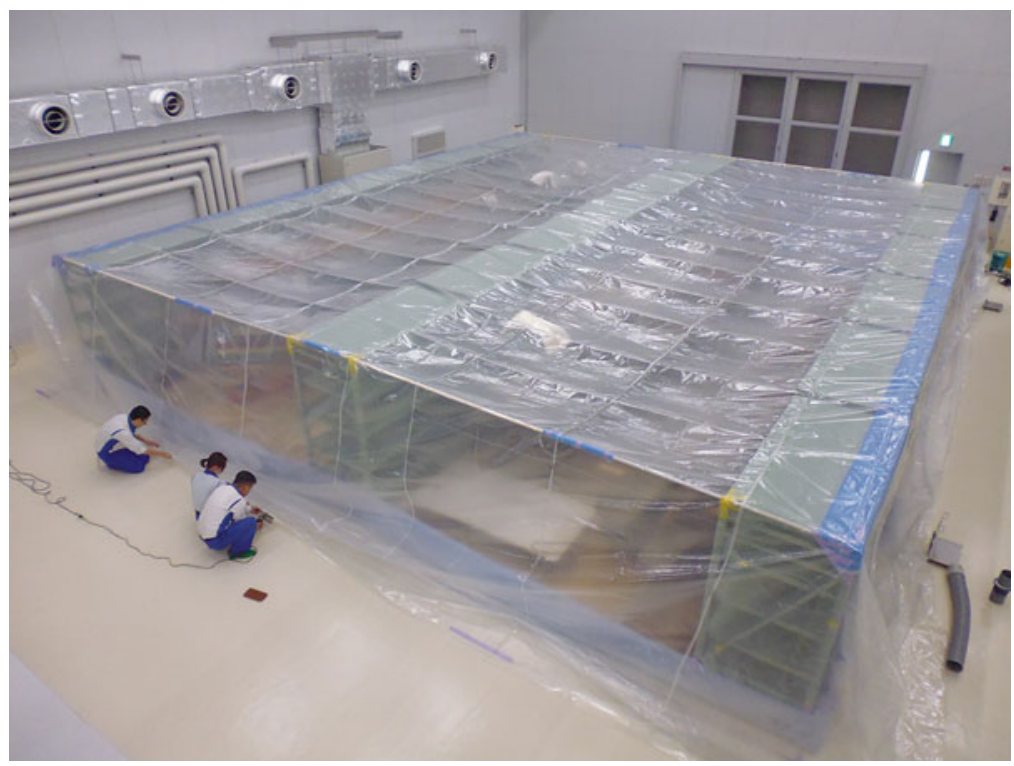

Fig. 9 Large wooden boats treated with carbon dioxide in an enclosure-type insecticidal treatment bag

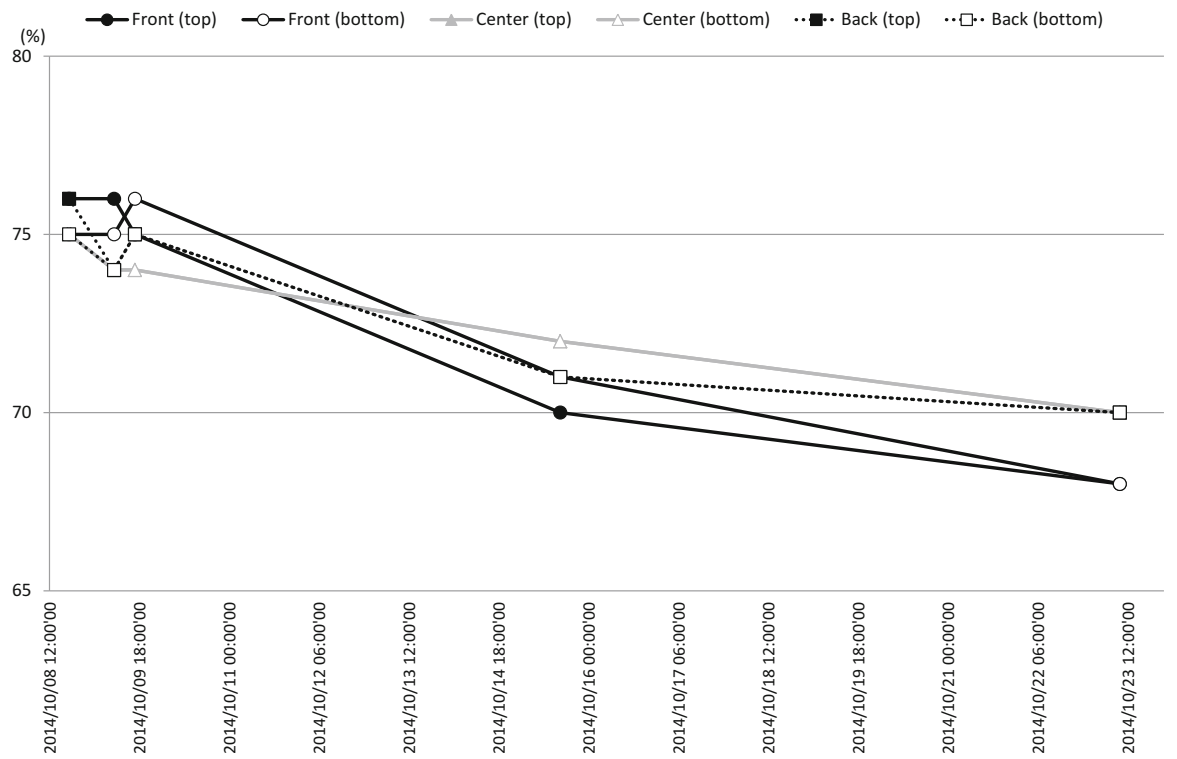

Fig. 10 Change in the concentration of carbon dioxide 


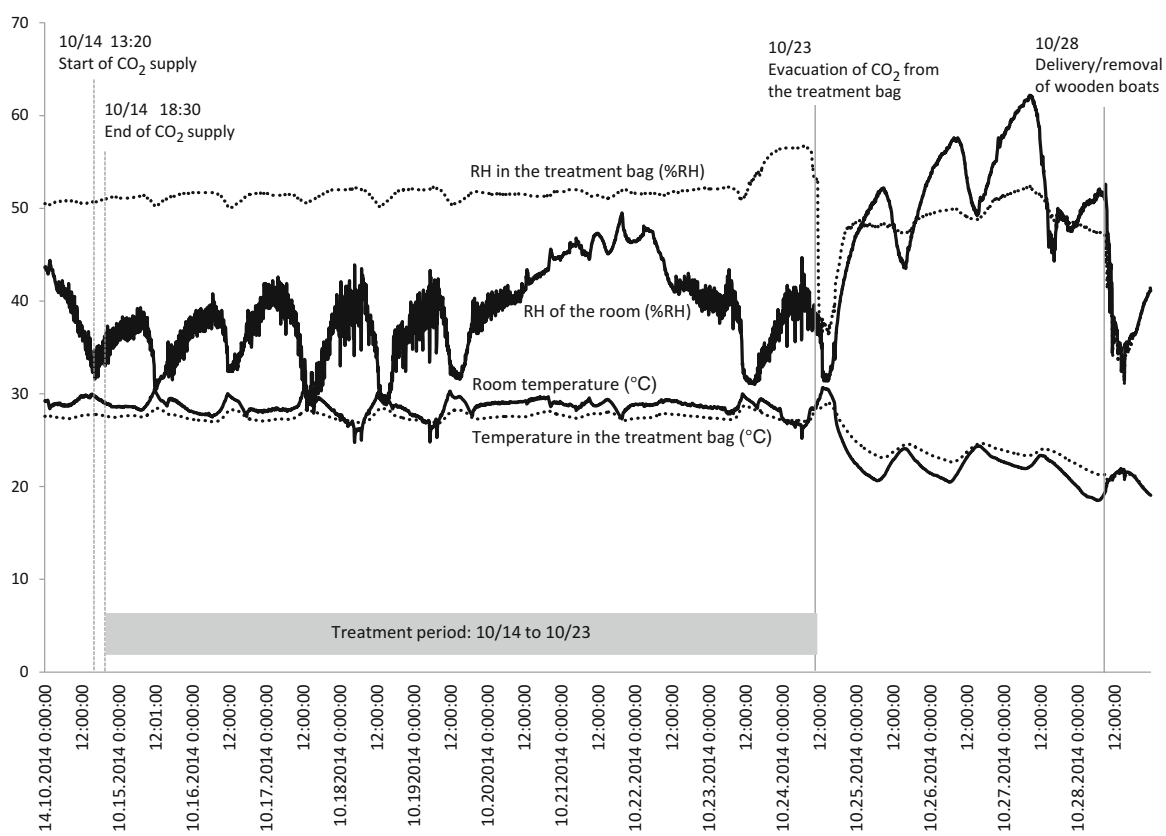

Fig. 11 Change in temperature and humidity during insecticidal treatment using $\mathrm{CO}_{2}$

Table 1 Results of assessment of the effect of insecticidal treatment using $\mathrm{CO}_{2}$

\begin{tabular}{l|l|l}
\hline $\begin{array}{l}\text { Location (Bag No. } \\
\text { 4) }\end{array}$ & $\begin{array}{l}\text { No. of } \\
\text { insects }\end{array}$ & Alive/dead \\
\hline Test insects (top) & 5 & $0 / 5$ \\
\hline Test insects (bottom) & 5 & $0 / 5$ \\
\hline Control & 5 & $5 / 0$ \\
\hline
\end{tabular}

enclosure-type bag measuring $11.5 \mathrm{~m}$ in length, $10 \mathrm{~m}$ in width, and $2 \mathrm{~m}$ in height. Figure 11 indicates change in temperature and relative humidity in the treatment bag. Table 1 summarizes the results of the assessment of the insecticidal effect. These data verify that insecticidal treatment using carbon dioxide can be performed on the scale described above.

\section{Future Topics}

This paper introduced a case of scientific research on preservation of museum collections, with focus on the development of an insecticidal treatment method using carbon dioxide. Since one of the preconditions for the development was that the treatment procedures could be performed by museum staff, close attention was paid to the assurance of worker safety at the development stage. However, there is a 
possibility that once workers become used to performing the procedures, they might pay less attention to safety management and neglect to check with the manual before executing the task. Thus, resolving this issue and providing safety education are major issues to be addressed in the future. Although the case introduced in this paper was successful, there are still some issues to overcome. For example, when carbon dioxide is supplied into the bag, the humidity in the bag decreases. So, there is a need to minimize the decrease in humidity. It is also necessary to develop a technology to achieve uniform distribution of carbon dioxide concentration in a large-scale treatment facility. There is a report that some cultural properties are damaged by pest insects, such as the longicorn beetle, against which treatment with carbon dioxide does not provide sufficient insecticidal effect. Thus, establishment of a methodology for the termination of these insects is another important issue.

As presented in the paper, research for improving the preservation and management of cultural properties is a very important and essential topic of scientific research on the preservation of museum collections.

Open Access This chapter is distributed under the terms of the Creative Commons AttributionNonCommercial 4.0 International License (http://creativecommons.org/licenses/by-nc/4.0/), which permits any noncommercial use, duplication, adaptation, distribution and reproduction in any medium or format, as long as you give appropriate credit to the original author(s) and the source, provide a link to the Creative Commons license and indicate if changes were made.

The images or other third party material in this chapter are included in the work's Creative Commons license, unless indicated otherwise in the credit line; if such material is not included in the work's Creative Commons license and the respective action is not permitted by statutory regulation, users will need to obtain permission from the license holder to duplicate, adapt or reproduce the material.

\section{References}

Kigawa, Rika, and Strang, Tom. 2011. Effects of fumigants and non-chemical treatments on DNA molecules and proteins: Case studies on natural history specimens and proteinaceous components of museum objects. In Integrated pest management for collections. Proceedings of 2011: A Pest Odyssey, 10 Years Later. London, 26-28 October 2011, ed. Peter Winsor, David Pinniger, Louise Bacon, Bob Child, Kerren Harris, Dee Lauder, Julie Phippard and Amber Xavier-Rowe, 115-122. Swindon: English Heritage.

Sonoda, Naoko. 2007. Conservation management system for tangible cultural resources at the National Museum of Ethnology, Osaka, Japan. In International symposium proceedings practice of conservation in museums - defining a vision for the practice of conservation in museums in the 21st century, ed. Conservation Division, Department of Cultural Properties, Tokyo National Museum, 97-103. Tokyo: Independent Administrative Institution, Tokyo National Museum.

Sonoda, Naoko, and Hidaka, Shingo. 2008. Between conservation and access: Implementation of integrated pest management at the National Museum of Ethnology, Osaka, Japan. In Conservation and access. Contributions to the London Congress 15-19 September 2008, The International Institute for Conservation of Historic and Artistic Works, ed. David Saunders, Joyce H. Townsend, and Sally Woodcock, 88-92. London: The International Institute for Conservation of Historic and Artistic Works. 
Sonoda, Naoko, and Hidaka, Shingo. 2011. Integrated pest management at the National Museum of Ethnology, Japan: Re-evaluation of preventive measures and control strategies. In Integrated pest management for collections. Proceedings of 2011: A Pest Odyssey, 10 Years Later. London, 26-28 October 2011, ed. Peter Winsor, David Pinniger, Louise Bacon, Bob Child, Kerren Harris, Dee Lauder, Julie Phippard and Amber Xavier-Rowe, 123-138. Swindon: English Heritage.

Strang, Tom, and Kigawa, Rika. 2011. Efficacy, effects, economics: The problem of distributing pest control advice to cover contingency. In Integrated pest management for collections. Proceedings of 2011: A Pest Odyssey, 10 Years Later. London, 26-28 October 2011, ed. Peter Winsor, David Pinniger, Louise Bacon, Bob Child, Kerren Harris, Dee Lauder, Julie Phippard and Amber Xavier-Rowe, 16-25. Swindon: English Heritage. 


\section{Part IV \\ Museums and Local Communities}




\title{
The Situation of Community Museums in the North of Thailand
}

\author{
Nitaya Kanokmongkol
}

\begin{abstract}
The community museums in the North of Thailand have different patterns: Ethnicity museums and local historical museums. Most ethnicity museums are located in the community of those ethnic people, and present ethnic identity, history, and folklore. Local historical museums are located in historical areas related to the folk life of the communities, and present the history of the areas and the communities. The author considers community museums in Thailand just one type of local museum managed by people, temples, and private units. The situations of the local museums might not be as stable as those of the national museums because the idea of each community unit is different in its understanding of the museum's social function. And nowadays, most local museums are just used as tourist places for the community economy.
\end{abstract}

\section{Introduction}

Museum establishment is not an original idea of Thailand but a Western influence when the Royal Court had a relationship with European countries in the Western colonial period of Asia. The first Thai museum started in 1857 when King Rama IV established a private collection gallery in the Royal Palace. He collected masterpieces, fragments of rare plants and animals, and scarce minerals from different regions. In the reign of King Rama V, the museum was used to present the country as a civilized land by changing it to the National Museum Bangkok open to the public and European guests. In the next reign, archaeological sites and ancient objects were protected as historical evidence, so museums had the mission of preserving, exhibiting, and teaching the public about archaeological evidence. In this time, regional national museums were established to protect artifacts in the regions (Jiraphong 1991). It was an important period for transmitting the museum idea from the Royal Court to the regional people, and introducing local museums later established by regional units and regional communities. Nowadays, the concept of the

\footnotetext{
N. Kanokmongkol $(\bowtie)$

Chiang Mai National Museum, 451 Super Highway rd., Chang Peok,

Chiang Mai 50300, Thailand

e-mail:kanitayaka@gmail.com
} 
local museum in Thailand is the "regional museum" of which there are several kinds according to the type of collection, story presentation, and organization, such as temple museums, company museums, learning museums in schools, folk museums, and community museums.

\section{Community Museum: A Subtype of the Local Museum}

Local museums in Thailand were born of the situation in each place and period. Most local museum owners are villagers who just want to build a collection gallery but without purpose or considering the type of their museum as a museological idea. Therefore, if we learn about and understand local museums in Thailand, we can know the basic situation of local Thai people. So the type of museum in Thailand should be recognized based on the understanding of the museum owner as one of three types: national museum, company or private museum (Fig. 1), or local museum.

For the types of local museum (Figs. 2 and 3), we can recognize subtypes from their collection, objective, and function. For example, a community museum is a local museum whose purpose is the following:

1. There is interaction with the community around the museum;

2. The community is the museum owner (Sirindhon Anthropology Center 2008).

3. The community uses the museum as a medium to promote their human rights or identity of ethnicity culture.

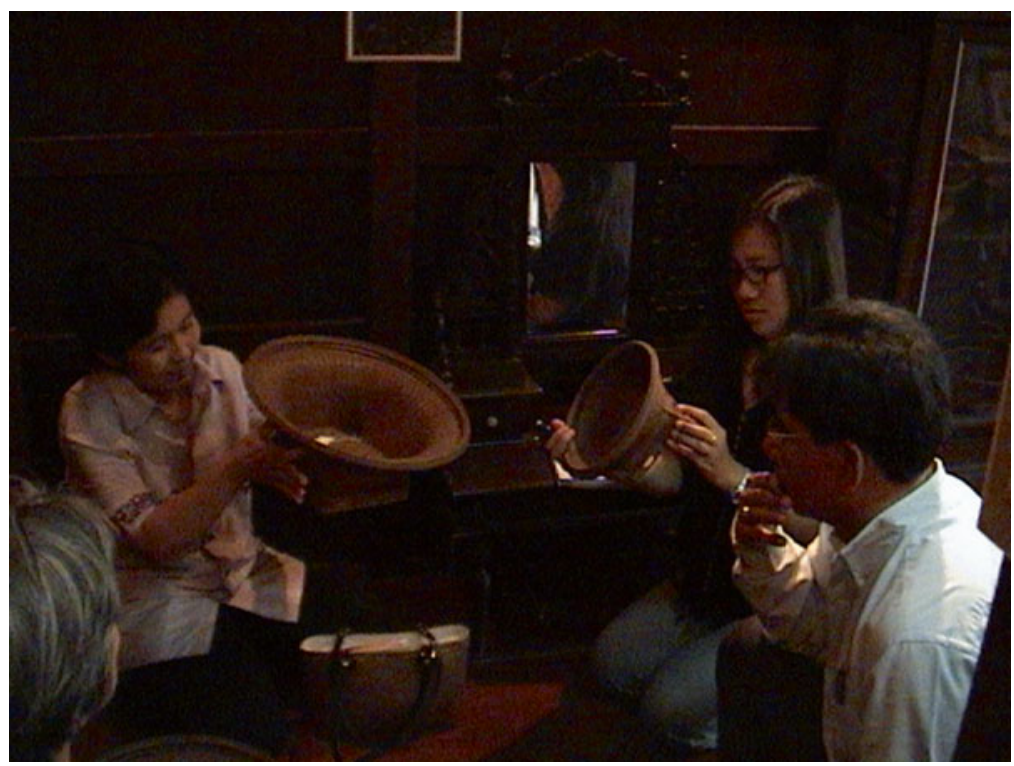

Fig. 1 Ban Kamaoon Museum, Chiang Mai: a private museum 


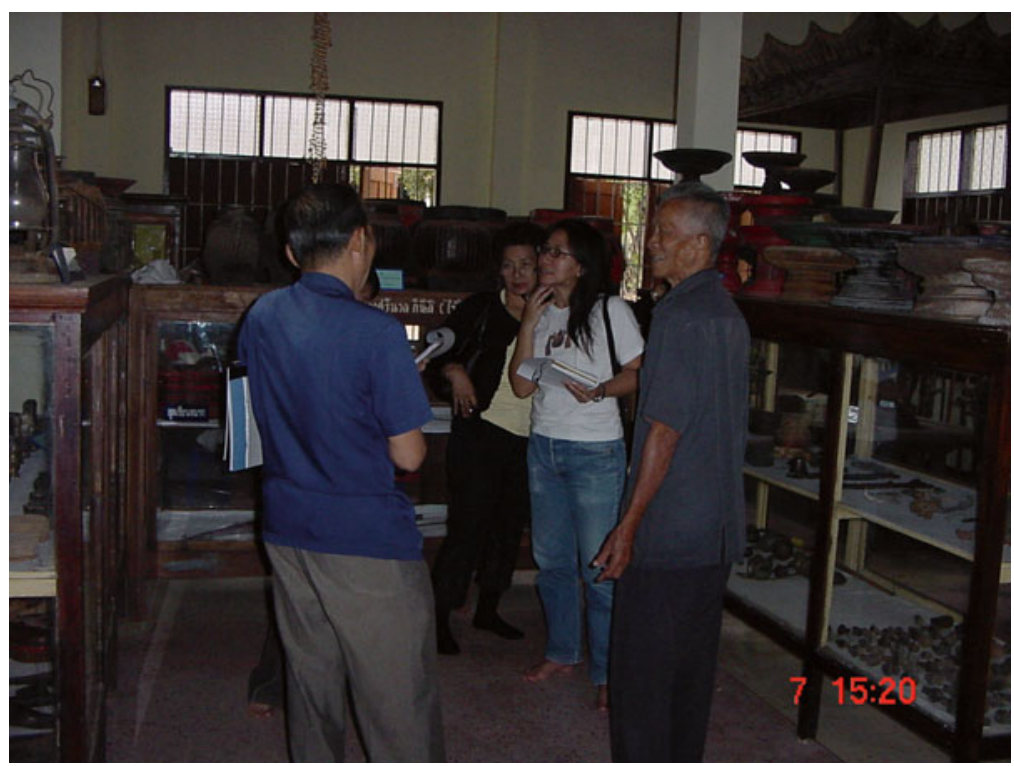

Fig. 2 Wat Laihin Museum, Lampang: a local museum located in a temple and managed by a community of Ban Laihin village

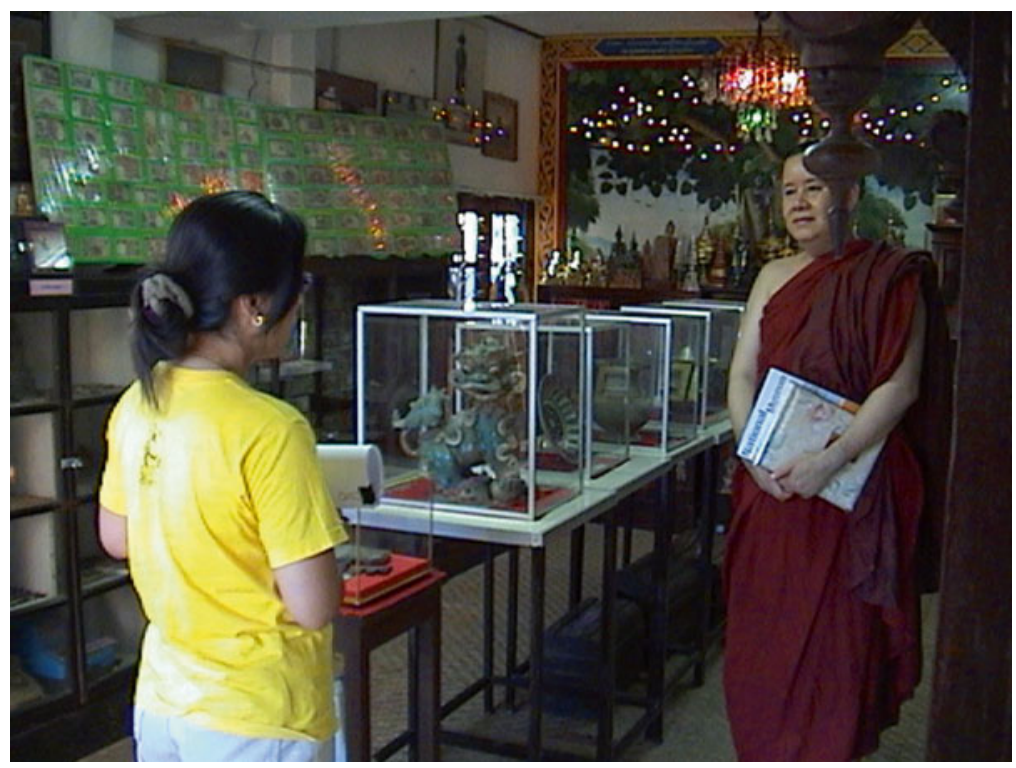

Fig. 3 Wat Pazang Museum, Lamphun: a local museum located in a temple and managed by an abbot of Pazang Temple 
The information from research papers about the situation in northern local museums by Chiang Mai Rajabht University (Jiraphong 1991) and Fine Arts Department (Fine Arts Department 1993) during 1991-1993 says that the number of local museums in the north is 170 . There are only six local museums that function as community museums. There were just a few community museums in the northern area 20 years ago. Now, the number of community museums has increased but some community museums in the last list have closed because of unstable policy and museum organization. In most local museums managed by temples or communities, the head was the abbot of the temple, director of the school, chief of the village, etc., so when the head changed, the policy also changed. If there was a new chief without interest in museum work, that museum always closed.

\section{Community Museums in the North of Thailand}

The community museums in the north have different patterns depending on collection, content, and organization. We can recognize patterns of community museums to be the following:

\subsection{Ethnicity Museum}

Most ethnicity museums are located in the community of those ethnic people. They have two objectives: the first is presentation of ethnic identity, history, and folklore as a place of memories, as a place for teaching their community, and as an ecotourist place. The second objective is a tool for promoting human rights or their cultural identity as one path of Thai society.

Thai museologists often say that this type of museum is a living exhibition because they model ethnic life such as traditional houses, barns, and folk life collections to exhibit as original houses that might already be changing in the real way of life. Visitor services are not formal services like in national museums or private museums. A visitor can visit by themselves during the day. But if they need a museum guide or an event for group tour visitors, they must make an appointment with the temple or community in advance.

Ethnicity museums organize interactive activities with community at least once a year. The most numerous type of activity is religious ritual fairs, using the museum as the center of the fair.

It is not only the outside form of the museum that is different; the management is also different in each museum.

As for Tai Khoan ${ }^{1}$ Museum at San Kang Pla Temple in Chiang Mai (Fig. 4), the current abbot of the temple built this museum in 1994 to present the cultural uniqueness of the Tai Khoan people, who are the community around the temple. Although the abbot is not a Tai Khoan person, he wants to support the community 

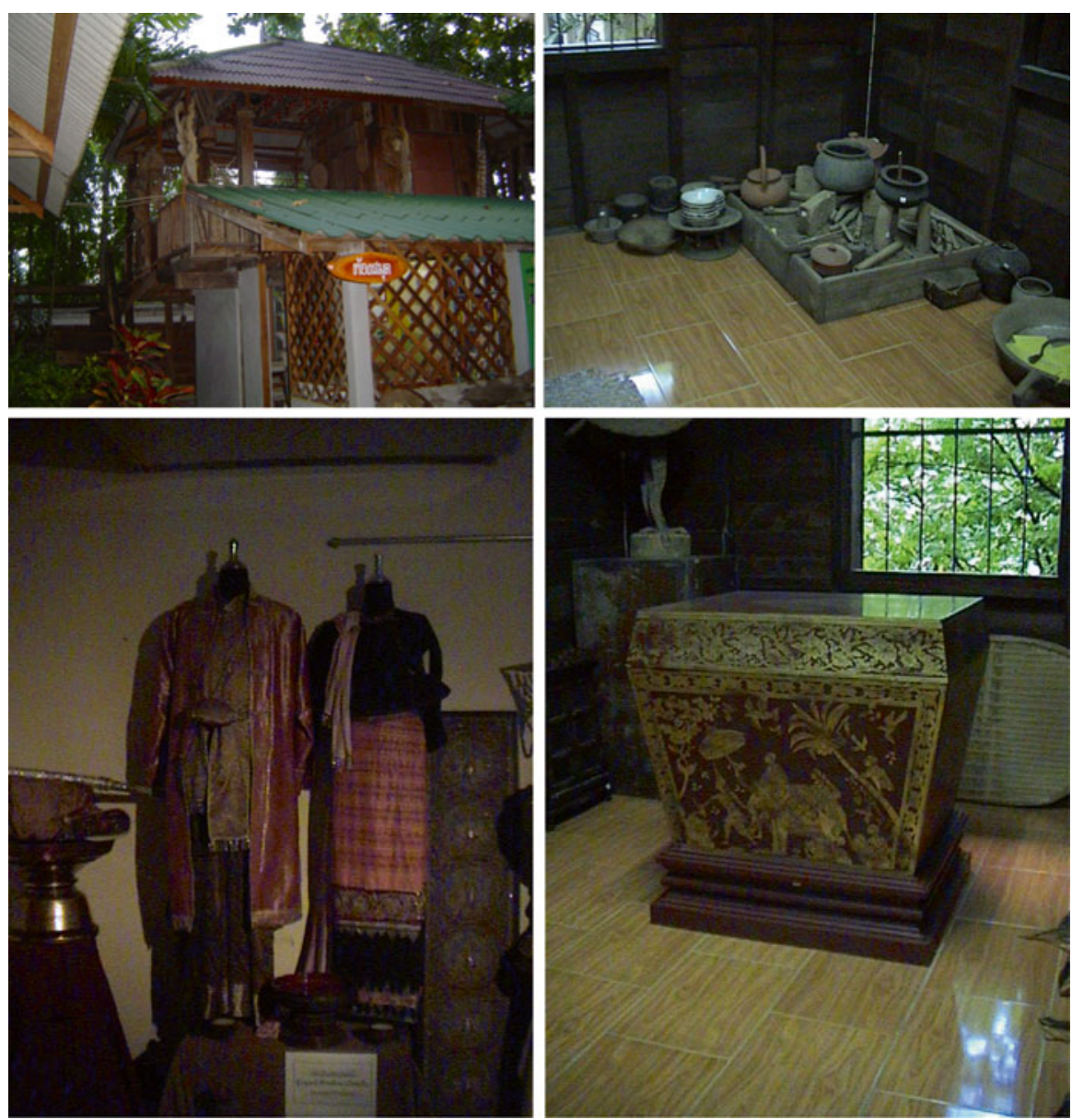

Fig. 4 Tai Khoan Museum at San Kang Pla Temple, Chiang Mai

around the temple to preserve their identity and present their social life. He interacts with the Tai Khoan community by calling for cooperation in building a traditional Tai Khoan house to be a museum in the temple area and donation of appliances to collect and display in the museum. Each year, the abbot will organize a Buddhist event so that visitors will visit this museum and see its merit. He said that the community of Tai Khoan will benefit from selling local products to visitors in this event.

Some notice from this museum management that the community does not really have a role in the museum because the abbot has all authority. And the community built an ethnicity museum in the village for their events after the museum was built at the temple. This is one case of a pale image of the community museum in Thailand.

The Tai Yong ${ }^{2}$ Museum at Pa Tal Temple in Chiang Mai (Fig. 5) is located in the temple and its purpose is to present the identity of ethnic people, the same as the Tai 

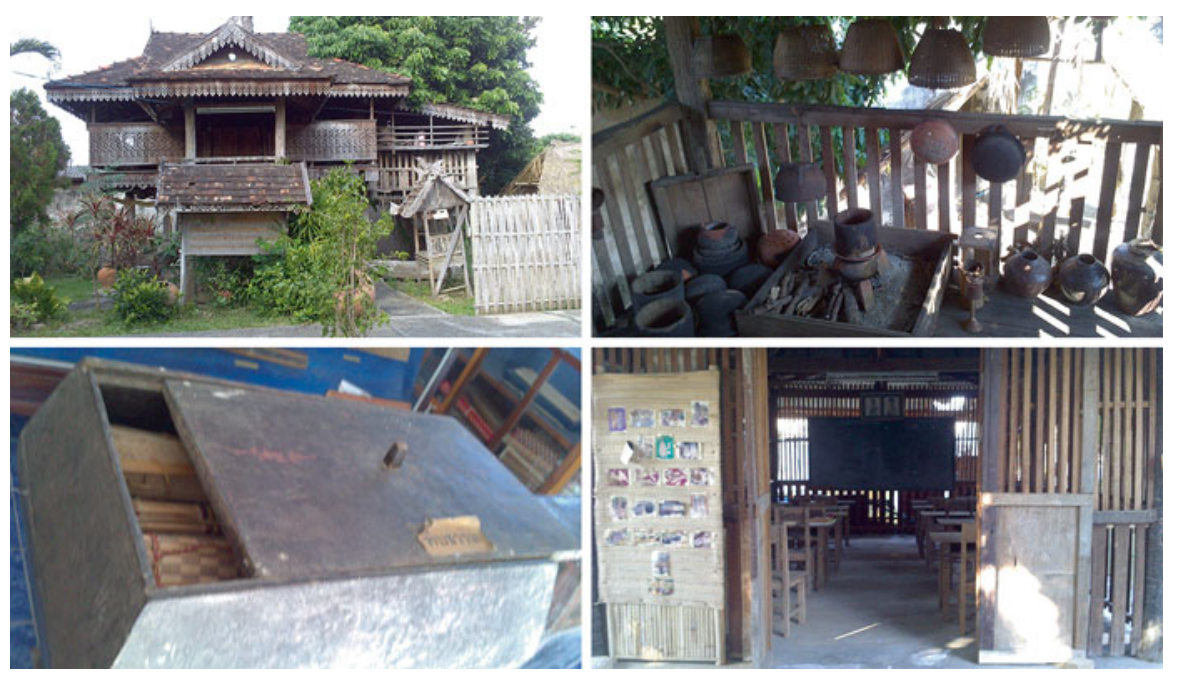

Fig. 5 Tai Yong Museum at Pa Tal Temple, Chiang Mai

Khoan Museum, but its management is different. The Tai Yong are an ethnic people who live around $\mathrm{Pa}$ Tal Temple. In 1999, they started to establish a museum in $\mathrm{Pa}$ Tal Temple, which is the center of the community, to present their unique culture and call for their ethnic people's rights to be admitted by society. They also use the museum as an ethnic cultural center for their youth.

The special point of this museum is establishment and management by the community. They share money to raise a budget of 300,000 baht for building the museum and donation appliances for the museum collection. The first museum gallery models a traditional house and displays its collection based on the original function of each room. The second gallery is an old barn from the village to model their folk agricultural methods. The last is a gallery of the Yong language, with a collection of palm leaf and mulberry manuscripts, and a small classroom for learning the Yong language of the community. Nowadays, the museum is used as a center for the community to organize activities to promote power of mind of the community to preserve their ethnic culture.

One ethnicity museum purpose is to be an eco-tourist site such as the Garden \& Museum of Mong ${ }^{3}$ Village in Doi Puy, Chiang Mai. It was established and is managed by 15 Mong families in the community. In 1987, they modeled three galleries to display a collection of Mong appliances with an explanation board. In the time after harvest, a group of Mong ladies come to do needlework and sell their products to tourists. During holidays, a student will guide the tourists at the museum to earn money, which cost is part of the community budget for museum maintenance.

This museum really seems to be a community museum because it is managed by the community and supports their economy. 


\subsection{Local Historical Museum}

This community museum is located in a historical area related to the folk life of the community. The main objective of the museum is to present the history of the area and the community. An important part of their collection is folk objects from this area and communication.

Wat Kaet Museum (Fig. 6) is a local historical museum in the Wat Kaet Karam business quarter on the bank of the Ping River in Chiang Mai. This museum started by collecting many votive objects in Wat Kaet to display as a collection in a gallery. These objects are appliances offered by the Wat Kaet community to Buddha, so they are important local historical evidence to relate the story of the families, the community, and all in this area.

The interesting point of this museum is management and cooperation by the community. The Committee for Preservation and Development of the Business Quarter has authority in the museum and organizes events.

The First Royal Factory Museum (Fang) in Chiang Mai (Fig. 7) is a museum where the current effects of royal projects in development of the ethnic communities in the area are displayed. The museum tries to interact with the community around the museum through the "Youth Guide": the youth who take a guide training and
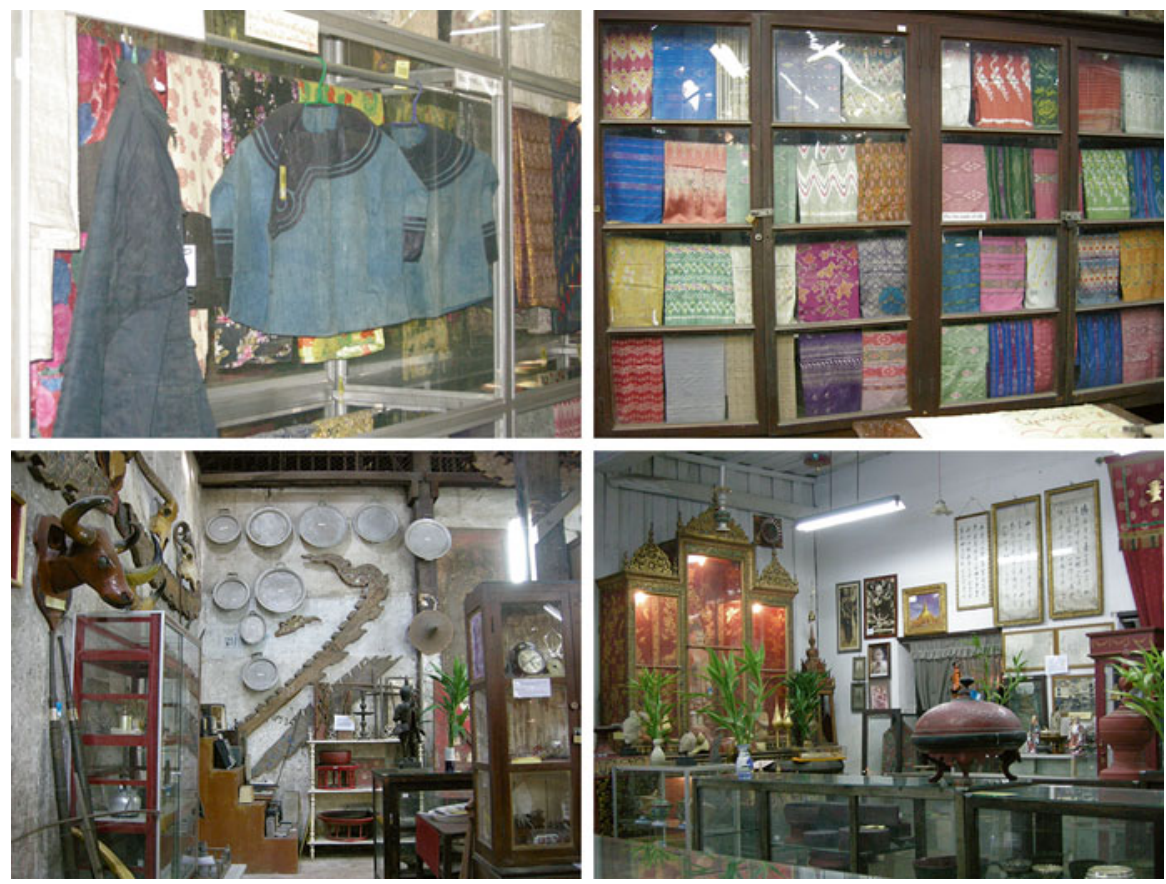

Fig. 6 Wat Kaet Museum: a local historical museum 

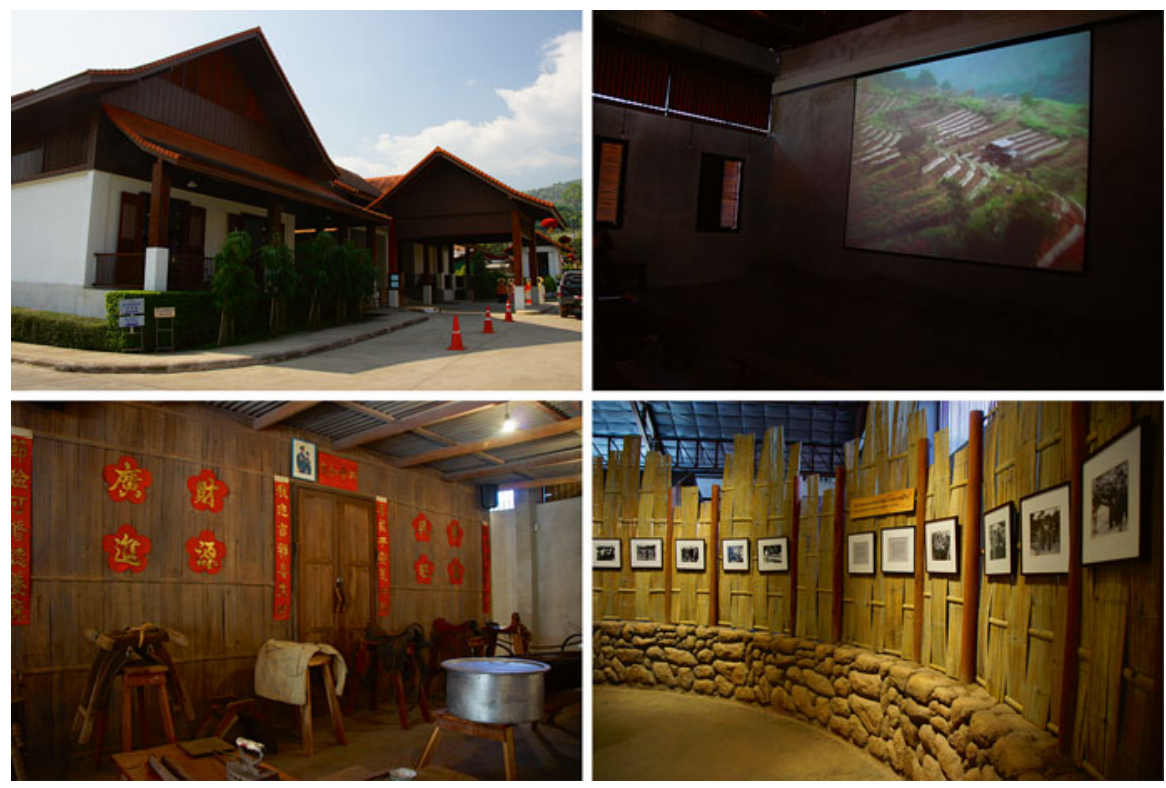

Fig. 7 The First Royal Factory Museum (Fang) in Chiang Mai

work at the museum in their holidays. The museum staff support them in guiding visitors through the village. The museum said, this is a way to link museum's content and benefit to the community around museum.

Community museums in Thailand might be just one type of local museum managed by people, temples, and private units that is a path of the local community. Their situations might not be as stable as those of the national museums because the idea of each community unit is different in its understanding of the museum's social function. And nowadays, most museums are just used as tourist places for the community economy.

\section{Notes}

1. The Tai Khaon is a group of ethnic people whose original settlement was in the north of Myanmar. The Tai Khaon people emigrated to populate northern Thailand in the Lan $\mathrm{Na}$ period, an old kingdom of northern Thai, thirteenth century (Kanokmongkol 2005).

2. The Tai Yong is a group of ethnic people whose original settlement was in the north of Myanmar. The Tai Yong people emigrated to populate northern Thailand in the Chiang Mai period, eighteenth century (Kanokmongkol 2005).

3. The Mong is a hill tribe who live on mountains in Thailand, Laos, Myanmar and South China (Kanokmongkol 2005).

Open Access This chapter is distributed under the terms of the Creative Commons AttributionNonCommercial 4.0 International License (http://creativecommons.org/licenses/by-nc/4.0/), which permits any noncommercial use, duplication, adaptation, distribution and reproduction in any medium or format, as long as you give appropriate credit to the original author(s) and the source, provide a link to the Creative Commons license and indicate if changes were made. 
The images or other third party material in this chapter are included in the work's Creative Commons license, unless indicated otherwise in the credit line; if such material is not included in the work's Creative Commons license and the respective action is not permitted by statutory regulation, users will need to obtain permission from the license holder to duplicate, adapt or reproduce the material.

\section{References}

Jiraphong, Buppa. 1991. The situation of local museum in Chiang Mai. Chiang Mai: Chiang Mai Rajabhat University. (In Thai).

Kanokmongkol, Nitaya (ed.). 2005. Research paper of ethnicity knowledge in Thailand for establishment the Ethnological Museum of Thailand. Pathum Thani Province, Thailand: Kanjanaphisek National Museum, Fine Arts Department (In Thai).

Sirindhon Anthropology Center. 2008. Museum memo: Realize experience from museum research and development. Bangkok: Samlada Company. (In Thai).

Fine Arts Department. 1993. Directory of museum in the north of Thailand. Bangkok: Amrin Printing \& Publishing. (In Thai). 


\title{
Interactive Museum Activities That Provide Venues for Innovation: Case Studies from the Lake Biwa Museum
}

\author{
Taisuke Ohtsuka
}

\begin{abstract}
How to define and construct a better relationship of coexistence between humans and nature through interactive museum activities is discussed based on the experiences of Lake Biwa Museum, Shiga, Japan. A better relationship cannot be determined objectively, and there is no justification for imposing one person's subjective good on others. So the museum has avoided expressions that imply value judgments. Experience-learning programs and interaction using staff communicators in the exhibition rooms may have helped visitors to conceive the formation of a better relationship, but appear to have done little toward arriving at mutual agreement or understanding. Workshops may be an effective means of exploring conceptual agreement and understanding among various people. Although our exploration toward mutually intelligible concepts of a better relationship is still at a quite primitive stage, some concepts such as sustainability appear to have been accepted by most residents of Shiga Prefecture. Thus, the Restoration of Fish Breeding in Paddy Fields project is analyzed as a social innovation generated by collaborative and interactive activities in which the museum has engaged. The original idea behind this project was advanced by a researcher of the museum who learned much about local experiences from farmers around Lake Biwa. The cooperative response of the prefectural government and local communities to the museum's suggestion appears to be based on rich social capital. Although the museum's researchers contributed no more than the idea and some related knowledge, other actors such as farmers, prefectural agencies, and researchers in other research institutes organized and advanced the project. The museum is still engaged to the extent of studying the project's effects or consequences, connecting researchers to the regions involved, and providing project-support participant events. We hope that further innovation along these lines will contribute to a "better relationship of coexistence between humans and lakes."
\end{abstract}

\footnotetext{
T. Ohtsuka ( $\square)$

Lake Biwa Museum, Oroshimo 1091, Kusatsu, Shiga 525-0001, Japan

e-mail: ohtsuka@lbm.go.jp 


\section{Introduction}

Museums must organize their activities in accordance with their own philosophies or missions. Nowadays, many Japanese museums set their own direction to construct better social and/or social-natural relationships. For instance, the mission of the Ibaraki Nature Museum is to "enhance harmonic coexistence of humans with nature, and promoting the amenity of cultural life." The Museum of Nature and Human Activities, Hyogo has a basic philosophy of "harmonious coexistence of nature and humans." The basic philosophy of the Lake Biwa Museum is "better relationship of coexistence between humans and lakes." They all aim at the betterment of coexistent relationships of humans with nature. This implies that the current state of these relationships is recognized as neither harmonious nor satisfactory. In other words, these museums seek to foster more sustainable and nature-friendly local societies. The following two problems arise, however, in attempting to organize practical activities that support such a philosophy or mission.

- How are better relationships defined?

- How can better relationships be realized?

In the present report, I will try to answer these two questions based on the experience of the Lake Biwa Museum; it is a prefectural museum of Shiga, $80 \%$ of whose total area is occupied by the catchment of Lake Biwa.

\section{How Are Better Relationships Determined?}

Naturally, within the philosophy of the Lake Biwa Museum, a "better relationship of coexistence between humans and lakes" cannot be defined objectively, because the concept is rooted in value judgments. Although scientific knowledge can contribute to the judgments, it cannot generate a sense of value by itself directly. Moreover, scientific activities are now generally regarded as model-building in a search for better explanation or predictive performance. Such models are not necessarily based on naïve realism, i.e., the belief that we can perceive the objective world directly.

There is no justification for imposing one person's subjective "good" on others. Such "good," however, can be imposed by an authority and/or power. An example of imposed value is displayed in the declaration formulated by Shiga Prefecture (2000) as a part of its Mother Lake Plan 21 concerning the Lake Biwa Comprehensive Development Plan launched in 1972 as a national program and concluded in 1997; this declaration stated that the "plan succeeded in providing a more effective utilization of the water resources of the lake and in significantly reducing flood damage," without critical remarks. Meanwhile, not a few people had opposed this development plan, mainly because they believed it would cause the destruction of the lake environment, and indeed, some negative effects on Lake Biwa's ecosystem have 
been reported (e.g., Nakanishi and Sekino 1997; Ohtsuka et al. 1996). Therefore, the conclusion that the development was "good" for people is imposed or, at least, one-sided. Mother Lake Plan 21 also states that "we must make the transition from the modern way of life based on mass production and consumption to one that is in harmony with the environment and is based on a symbiosis of humans and nature." Even within the same declaration, the standard of value appears to have largely shifted away from appreciation of the development noted above. It is still the case, however, that the values are imposed on people.

From its inception, the Lake Biwa Museum has studiously avoided the use of value-judgment expressions regarding a "better relationship of coexistence between humans and lakes." Nunotani (2014) explained the reason as follows: "Social problems arise depending on the social situations of the age, and naturally, their evaluations also change in successive periods. Therefore, our museum will provide people with information for thinking about such problems instead of making evaluations." This attitude has been consistently implemented by the museum in its exhibitions and other activities. Although the museum does not impose any concepts of values on people, there is also little evidence that its activities contribute much to consensusbuilding on its theme of better coexistence. There may be two different reasons for this. One is that the visitors themselves often expect or require a museum to present value judgments on the topics covered by the exhibits instead of thinking by themselves. Such users may feel that making their own value judgments is difficult. Another is the lack of a consensus-building process. Even if the users could construct concepts of values by themselves, making such concepts mutually agreeable or even intelligible is not guaranteed.

Kada (2001) argued for a strategy of translating knowledge into social action. It needs at least two steps, the first of which is personal experience, i.e., experiencing something directly and finding its meaning in one's own life. The second is shared social experiences, i.e., personal experiences that are shared in and supported by communities. Interactive museum activities are presumably effective for learning by experience. In particular, as far as the participants are constructing experiential learning occurring in a museum, it should to a great extent contribute to this process. The Lake Biwa Museum devised a new system to enhance the experiences of visitors when it opened in 1996. It is based on a group of communicators in the exhibition rooms who are now called Tenji-koryu-in. They communicate with visitors directly and/or mediate the interaction of visitors with the exhibitions. An effective way to conduct such mediation is to listen to the experiences of the visitors related to the exhibition context (Fig. 1). This helps connect the exhibition contents with the visitor's own experiences and promotes reconstruction of the experiences, a process called Jibun-ka or "personalization" by Yukiko Kada. Such experiences may also expand common understanding and thus contribute to the construction of mutual agreement or understanding. Personal and internalized experiences are necessary for this, but are not in themselves a sufficient basis for mutual agreement or understanding. Doxastic conflict is often encountered even among people educated through similar experiences. Value relativism can prevent immediate conflicts and the consequent decrease in motivation, but also mutual agreement and understanding. 

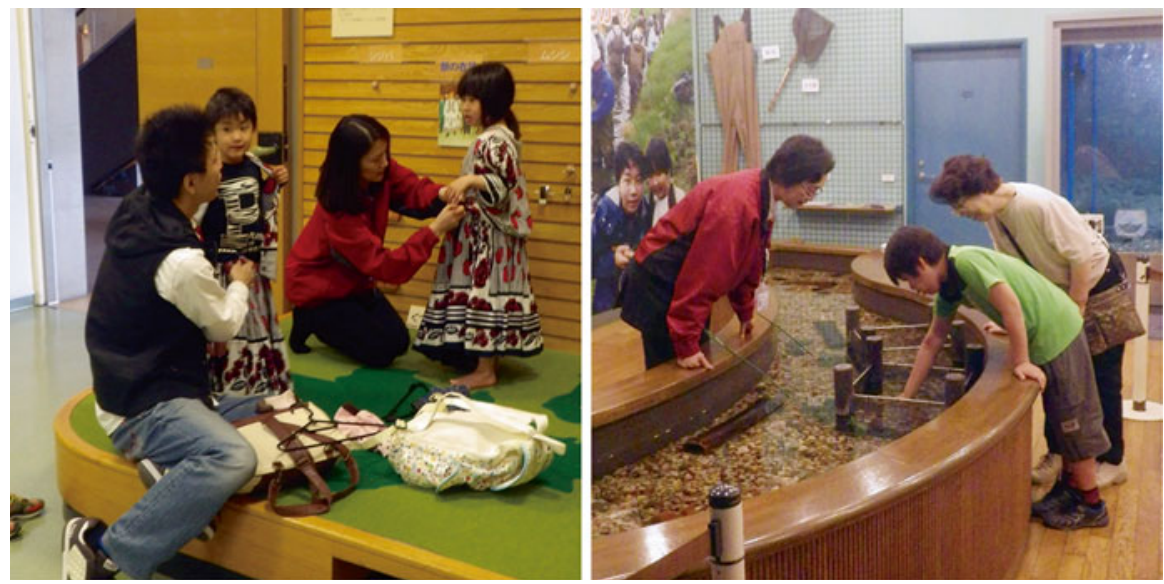

Fig. 1 Activities of communicators called Tenji-koryu-in

One possible approach to overcoming both doxastic conflict and value relativism is to examine the interests or motivations that underlie the value judgments. If the differences in the interests or motivations that serve as a basis of concept formation become clear, different concepts of values will become mutually understandable. Another approach is the organization of joint activities among diverse members or groups. Common experiences in such activities can form a common concept of values. In addition, contradictions between different concepts of values in collaborative activities possibly serve as a driving force in constructing innovative concepts (Engeström 1987; Engeström 2008).

Workshops may be a good avenue for exploring routes toward mutually intelligible or understandable concepts, because they can be organized so as to provide common experiences, to explore the underlying interests or motivations of each concept, and also to create dialectical discussion seeking innovative ideas or concepts. The Lake Biwa Museum, regrettably, has not organized such a workshop, but a series of annual workshops with similar aims has been organized by the Mother Lake Forum founded in 2012. These are called "Biwa-Comi Meetings" where "Comi" denotes community, communication, and commitment. The theme of each workshop is set by the committee. Various actors involved in the Lake Biwa catchment area discuss potential measures towards a better future for the lake. Interests, motivations, and problems are shared on the basis of mutual respect for different situations, experiences, and concepts. The workshops are not focused on agreements or conclusions, but give weight to shared interests, motivations, and problems. They aim to be a venue for finding mutually different or common concepts and for considering what each of the participants can do for the lake (http://mlf. shiga.jp/biwacomi). This practice appears to be improving year by year, and they thus stand far ahead of the Lake Biwa Museum. On the other hand, one must beware that such a practice comes to work as a control system for governmentality, i.e., a measure whereby governments try to produce citizens best suited to fulfill those 
governments' policies. The concepts, methods, and achievements of the "Biwa-Comi Meetings" need to be evolved critically, and new interactive museum activities not based on predetermined public policies should be constructed.

\section{How Can Better Relationships Be Achieved?}

As is discussed above, our efforts to arrive at a mutual agreement on, or understanding of, a "better relationship of coexistence between humans and lakes" is at a rather primitive stage. Nevertheless, some consensus among most regional actors has surely been found. For instance, a public opinion poll in Shiga Prefecture found that the local political topics ranked as the top three in terms of satisfaction level are "environmental arrangements that enable experiences of nature in our own backyard," "food security," and "maintenance of beautiful rural landscapes and green forests" (Shiga Prefecture 2014). This indicates that many residents regard the satisfaction with these as "good" and the related political measures as having been successfully worked out. Interestingly, they are all deeply associated with sustainable relationships between humans and nature in the Lake Biwa watershed. Therefore, it seems that the concept of sustainability can be accepted as a common "good" by most residents in Shiga Prefecture.

Aspirations for sustainability usually come from the recognition that it has been impaired. Many of us may feel that nature has retreated from our living areas, food security has been threatened, and the landscapes around farming and mountain villages have deteriorated, at least that such was the case in the past. Such experiences direct us to regenerating a sustainable relationship between humans and nature. Because such regeneration cannot be a simple restoration to the original state, it requires exploratory trials and social innovations, i.e., new strategies, concepts, ideas, and organizations that meet social needs. With this in mind, I will now introduce and analyze a case in which the Lake Biwa Museum contributed to a social activity aimed at regenerating a sustainable relationship with Lake Biwa.

In 2001, Shiga Prefecture started its "Sakana-no-yurikago-suiden" project, that is, "Restoration of Fish Breeding in Paddy Fields," around Lake Biwa. This project aims at rural environmental improvement by encouraging the resumption of fish migration between rice paddies and Lake Biwa. Land consolidation programs executed between the 1960s and 1980s raised the level of the rice paddies, and therefore generated considerable vertical drops (usually more than a meter) between the rice paddies and the water surface of the drainage canals. As a consequence, it became impossible for fish to enter the paddies for spawning. To remedy this situation, participating rural communities usually set fish-ladder cascades that work by elevating the water level of the upper reaches of a drainage canal through the installation of a series of successively higher flashboards; this sort of installation enables fish to enter the paddies adjacent to the canal by way of their drains (Fig. 2). By 2011, this program had expanded to about $1.2 \mathrm{~km}^{2}$ of paddy fields (Ohtsuka 2014). 


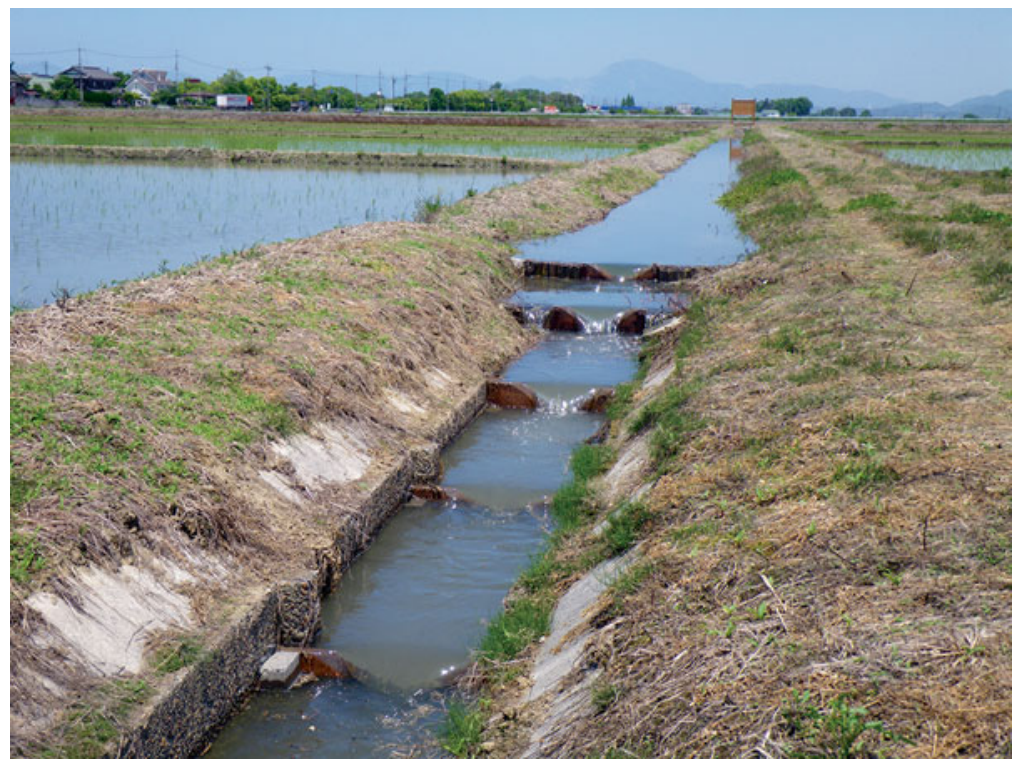

Fig. 2 A fish-ladder cascade set in a drainage canal (ㄷ Shigefumi Kanao)

The "Sakana-no-yurikago-suiden" project was originally inspired by the results of a comprehensive research program on paddy fields conducted by the Lake Biwa Museum from 1996 to 1998. In this collaborative study, some researchers learned from rice farmers that many fish used to spawn in rice paddies (Kada 2000; Yasumuro 2000). The most surprising story concerned the uojima, or fish island, phenomenon: during the rainy season in early summer, vast numbers of fish often invaded the paddy fields around Lake Biwa to spawn there, agglomerating to make an "island" (Kada 2000). After the research program terminated, a researcher released a pair of adult round crucian carp, Carassius buergeri grandoculis (Fig. 3), into a rice paddy and thereby obtained a few tens of thousands of juvenile fish. Based on these preliminary results, Yukiko Kada, who had been the principal researcher of the abovementioned research project, was convinced that fish such as the round crucian carp could still propagate and grow in rice paddies if the paddies were accessible. This fish is an especially important for residents in Shiga Prefecture because it is an endemic subspecies of Lake Biwa, and is designated as endangered in the Environment Ministry's national red list, but is nonetheless a major fishery resource as a principal ingredient in funa-zushi, a specialty food of Shiga (Maehata 2013; Ohtsuka 2014). Dr. Kada persuaded officials of the Department of Agriculture and Fisheries, Shiga Prefecture to undertake a new official project to enhance fish breeding in rice paddies. Preliminary efforts to develop fish passes and to design experiments to confirm the utility of rice paddies as fish nurseries were started in 2001. Soon after, local people in various places around Lake Biwa began to take steps to implement these ideas (Kada 2012). 


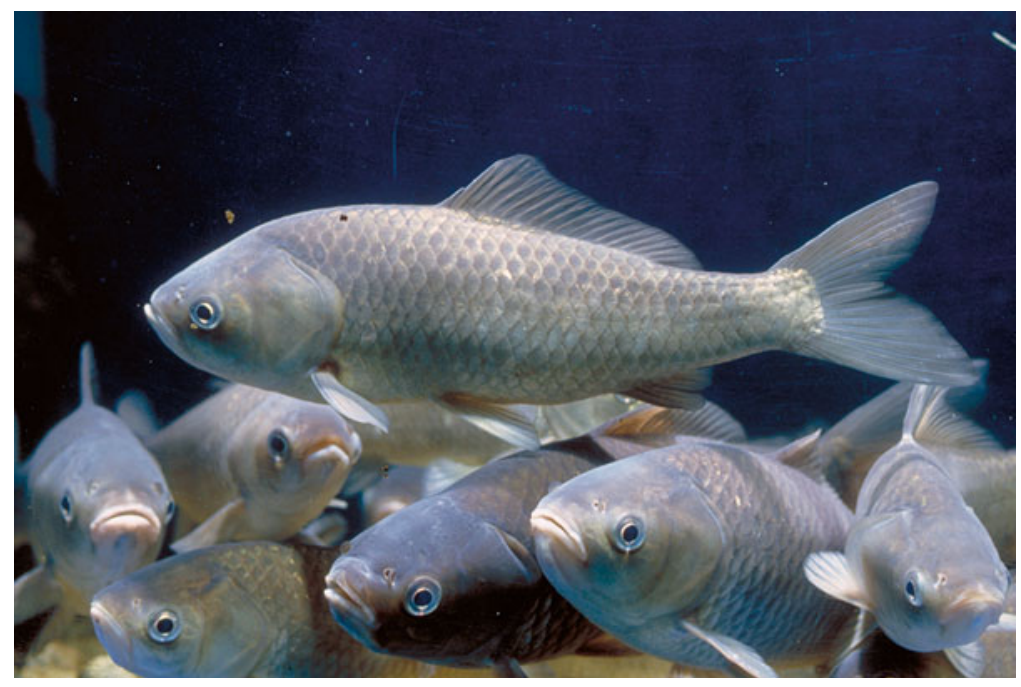

Fig. 3 Round crucian carp, Carassius buergeri grandoculis (CLake Biwa Museum)

There are three important points to note in evaluating the role of the Lake Biwa Museum in this important social innovation. First, the original idea of this project was advanced by a researcher from the museum who relied on testimony concerning personal experiences of farmers around Lake Biwa (Kada 2000, 2012). The idea was probably deemed acceptable by the local communities because it was based on their own experiences. Second, the cooperative response of the communities and local government to the program suggested by the museum appears to have been based on rich social capital (Tanaka 2006). According to the definition offered by the OECD (2007), social capital is "networks together with shared norms, values and understandings that facilitate cooperation within or among groups." In the present case, it may be largely attributable to the regional social characteristics of Shiga Prefecture (Makino and Yang 2010), but the community-based approaches of both the museum researchers and the local government officials contributed to an increase in the social capital in these regions. Third, the museum researchers did not contribute more than the original idea and some related background knowledge during the first few years of the project. Technical development mainly took place at other research establishments, policy formation and implementation was undertaken by officials of the prefecture's Department of Agriculture and Fisheries, and the practices were carried out by local communities (Tanaka 2006). In this case, the orientation of the museum's studies, toward problem-posing rather than problem-solving, was probably conducive to establishing and maintaining this collaboration.

After the "Sakana-no-yurikago-suiden" project was moved into the action phase, the Lake Biwa Museum studied its effects or consequences while also introducing to the communities new researchers from inside or outside the museum who could enhance the program's effectiveness. In addition, some of the museum researchers frequently provided support as lecturers or interpreters to public viewing programs 


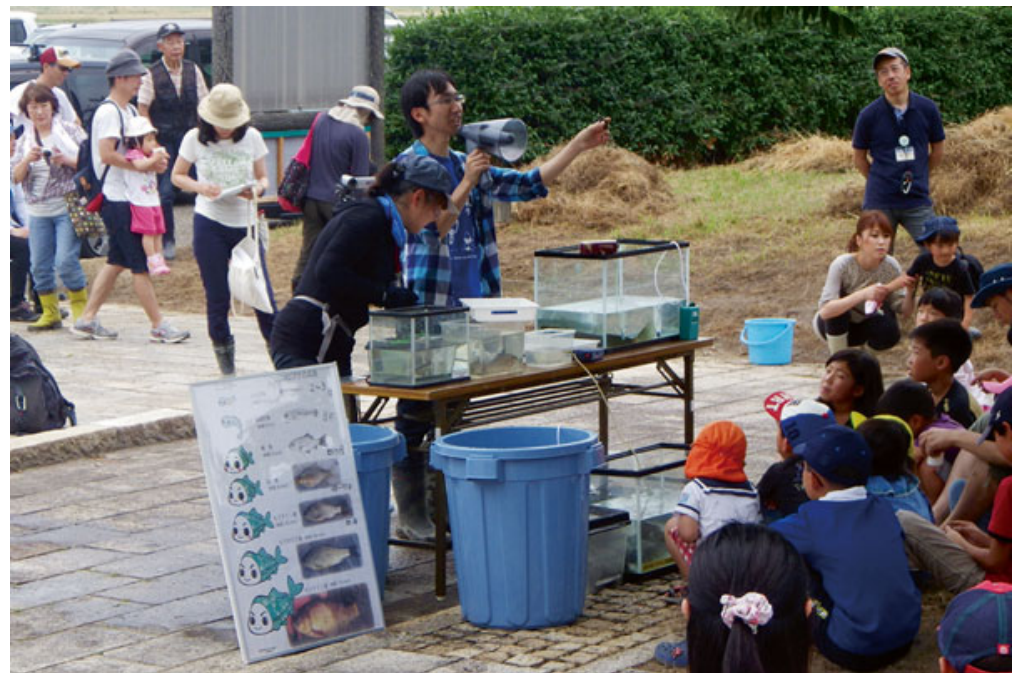

Fig. 4 Museum researchers providing support to public viewing programs

mainly conducted by local farmers' groups and coordinated by officials of the local government (Kanao and Ohtsuka 2013) (Fig. 4). It is hoped that such collaborative and interactive activities including the Lake Biwa Museum among the actors will produce further social innovations that bring a "better relationship of coexistence between humans and lakes" closer to fruition.

Acknowledgement I wish to thank Dr. Mark J. Grygier for his advice including English corrections.

Open Access This chapter is distributed under the terms of the Creative Commons AttributionNonCommercial 4.0 International License (http://creativecommons.org/licenses/by-nc/4.0/), which permits any noncommercial use, duplication, adaptation, distribution and reproduction in any medium or format, as long as you give appropriate credit to the original author(s) and the source, provide a link to the Creative Commons license and indicate if changes were made.

The images or other third party material in this chapter are included in the work's Creative Commons license, unless indicated otherwise in the credit line; if such material is not included in the work's Creative Commons license and the respective action is not permitted by statutory regulation, users will need to obtain permission from the license holder to duplicate, adapt or reproduce the material.

\section{References}

Engeström, Y. 1987. Learning by expanding: An activity-theoretical approach to developmental research. Orienta-Konsultit: Helsinki.

Engeström, Y. 2008. From teams to knots: Activity-theoretical studies of collaboration and learning at work. Cambridge: Cambridge University Press. 
Kada, Y. 2000. Seibutsu-tayousei to bunka no tayousei-Mizube-kankyo no jissenteki-hozen-ron ni mukete [Biodiversity and cultural diversity - Toward a practical methodology for conserving waterfront environments]. In No-san-gyoson to seibutsu-tayousei [Rural villages and biodiversity], ed. T. Udagawa, 134-150. Tokyo: Ie-no-hikari Association. (In Japanese).

Kada, Y. 2001. Chiiki-shakai de no hakubutsukan riyo no jissen-teki tenkai no kanousei-BiwakoHakubutsukan e no raikan ga kenmin ni motarasu hakubutsukan-image kara nani wo tenbo dekiru no ka [Possibility of practical development of museum utilizations in local areas - What can be put in perspective based on the visitors' images of Lake Biwa Museum]. In Shisaku to site no hakubutsukan no jissen-teki hyoka-Biwako-Hakubutsukan no Keizai-teki, Bunka-teki, Shakai-teki kouka no kenkyu [Practical evaluation of a museum as a political measure-Studies of economic, cultural, and social effects of Lake Biwa Museum], ed. Murayama, H. 138-146. Tokyo: Yuzankaku. (In Japanese).

Kada, Y. 2012. Chiji wa nani ga dekiru no ka- "Nihon byou” no chiryou wa chiiki kara [What can a governor do?-Japanese disease is cured in a local area]. Nagoya: Fubaisha. (In Japanese).

Kanao, S., and T. Ohtsuka. 2013. Lake Biwa basin as a venue for paddy field ecosystem studies: The past, present and future. Aquabiology 35: 426-432. (In Japanese with English abstract).

Maehata, M. 2013. Why do cyprinid fishes of Lake Biwa swim up to the paddy fields in the rice planting season? Aquabiology 35: 208-214. (In Japanese with English abstract).

Makino, A., and P. Yang. 2010. Analysis of the social conditions conducive to sustainable organic rice farming around Lake Biwa in Japan. Asian Rural Sociology 4: 284-289.

Nakanishi, M., and T. Sekino. 1997. Recent drastic changes in Lake Biwa. Bio-communities, with special attention to exploitation of the littoral zone. GeoJournal 40: 63-67.

Nunotani, T. 2014. Social duties of the museum for nature conservation. Bulletin of Kansai Organization for Nature Conservation 36: 81-82. (In Japanese).

OECD. 2007. Human capital: How what you know shapes your life. Paris: OECD Publishing.

Ohtsuka, T., K. Iwasaki, A. Kumagai, and T. Konishi. 1996. Decline of the emergent macrophyte zone along the eastern shore of Laka Biwa's South Basin. Japanese Journal of Limnology 57 : 261-266. (In Japanese with English abstract).

Ohtsuka, T. 2014. Nursery Grounds for Round Crucian Carp, Carassius auratus grandoculis, in Rice Paddies around Lake Biwa. In Social-ecological restoration in paddy-dominated landscapes, ed. U. Nishikawa and T. Miyashita, 139-164. Tokyo: Springer.

Shiga Prefecture. 2000. Mother Lake 21 plan. Summary and backgrounds. Shiga Prefecture. http:// www.pref.shiga.lg.jp/biwako/koai/mother21-e/0.pdf. Accessed 10 Feb 2015.

Shiga Prefecture. 2014. Dai 47 kai Shiga kensei seron chosa [47th public opinion poll of Shiga Prefecture]. Otsu: Public Relations Division of Shiga Prefecture. (In Japanese).

Tanaka, S. 2006. "Sakana-no-Yurikago-Suiden" project [Project for "Restoration of Fish Breeding Mechanism in Paddy Fields"]. In Chiiki to kankyo ga yomigaeru suiden saisei [Restoring rice paddy wetland environments and the local sustainable society], ed. I. Washitani, 104-124. Tokyo: Ienohikari Kyokai. (In Japanese).

Yasumuro, T. 2000. No-san-gyoson no minzoku to seibutsu-tayousei [Rural folklore and biodiversity]. In No-san-gyoson to seibutsu-tayousei [Rural villages and biodiversity], ed. T. Udagawa, 134-150. Tokyo: Ie-no-hikari Association. (In Japanese). 


\title{
Museums as Hubs for Disaster Recovery and Rebuilding Communities
}

\author{
Isao Hayashi
}

\begin{abstract}
Among many museums throughout Japan that address the subject of disaster, the attention was drawn to the Chuetsu Earthquake Memorial Corridor which is composed of four facilities and three parks. One facility in Nagaoka acts as gateway to the Corridor, another in Ojiya is responsible for disaster prevention education, the one in Kawaguchi aims to reveal the connections born between people, and the one in Yamakoshi recounts the history, culture, and reconstruction of the village. Memorial parks were established in Myoken as a "park for prayer," in Kogomo as a "park for remembering," and at the Epicenter as a "park for beginnings." The author thus introduced the significance of involving the local people in the planning process and management of facilities that represent and reflect their own experiences.
\end{abstract}

\section{Introduction}

Disaster-induced deaths in the Asian-Pacific region account for more than half of the total number of victims in the world (Fig. 1). Needless to say, most countries, regions, and communities have been making efforts to reduce the number of deaths caused by all kinds of disaster. At the same time, recently, working out recovery strategies from a disaster in advance is one of the new focal issues in the field of disaster studies.

After the occurrence of the Great East Japan Earthquake, in the "Towards Reconstruction" presented by the Reconstruction Design Council at the end of June 2011, the first item listed among the Seven Principles for the Reconstruction Framework stated that "there is no other starting point for the path to recovery than to remember and honor the many lives that have been lost. Accordingly, we shall record the disaster for eternity, including through the creation of memorial forests and monuments, and we shall have the disaster scientifically analyzed by a broad range of scholars to draw lessons that will be shared with the world and passed down to posterity." Moreover, in order for this to be incorporated, the establishment

\footnotetext{
I. Hayashi $(\bowtie)$

National Museum of Ethnology, Senri Expo Park, Suita, Osaka 565-8511, Japan

e-mail: isaki@idc.minpaku.ac.jp
} 


\section{More and increasing disasters in Asia}

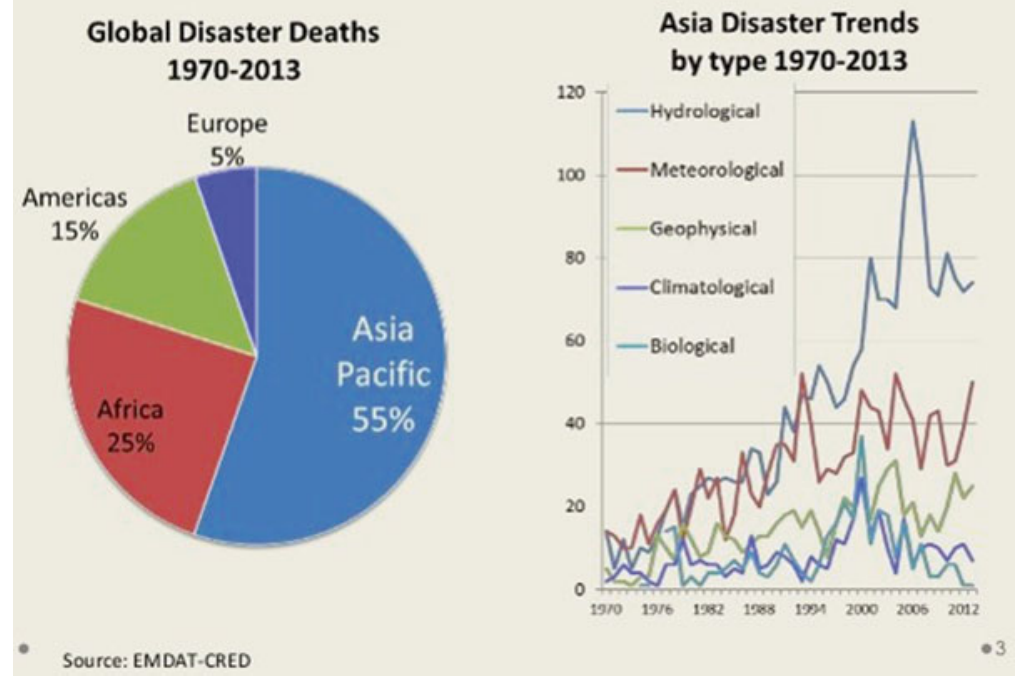

Fig. 1 Global disaster deaths and Asia disaster trends for 1970-2013 (Source: Thomas (2014))

of facilities, such as memorial parks, monuments, and severely damaged buildings, for conveying experiences and lessons learned from the disaster in the future was planned as part of the reconstruction plans of the municipalities and prefectures affected by the disaster, and some of those localities are already in the process of implementing these plans. Museums have been recognized as an important medium for disaster risk reduction by transferring and sharing past disaster experiences.

There are many museums throughout Japan that address the subject of disasters. The Disaster Reduction and Human Renovation Institution in Kobe is a facility introducing the destruction and activities in the rescue and recovery process of the 1995 Great Hanshin-Awaji Earthquake. There are about 500,000 visitors a year, and it is not only an exhibition hall, but also a research institution related to disasters and disaster prevention that holds training programs mainly targeting government officials in charge of disaster prevention. The Inamura-no-Hi no Yakata (Fire of Rice Sheaves Mansion), located in Yuasa Town of Wakayama Prefecture, is a facility that encompasses the neighboring Tsunami Educational Center and in which the old house of Goryou Hamaguchi, the hero in the story of the "Fire of Rice Sheaves," serves as a memorial hall. The Mt. Unzen Disaster Memorial Hall in the Shimabara Peninsula of Nagasaki Prefecture serves as a facility related to volcanoes. These facilities are large-scale, specialized museums related to disasters, and not only do they have exhibitions on past disasters, they are also places where people can learn about measures against potential future disasters, namely disaster prevention and reduction. There are also many other facilities that have adopted the subject of 
disasters as part of their exhibitions. The common thread is that these facilities have the goal not only of introducing past disasters, but also of putting lessons learned from disasters to use for future disaster prevention and reduction.

The Chuetsu Earthquake Memorial Corridor is unique and it deserves attention. In addition to preserving and disseminating memories and records of the disaster, passing on lessons learned from experiencing the disaster, and cultivating awareness of disaster prevention and reduction, the Corridor had local people involved in the establishment and management of the facilities, it is positioned to assist in rebuilding the lives of those people, and aids in reviving and developing communities located in intermediary areas between plains and mountains severely damaged by the earthquake. I will introduce here the significance of involving the local people in the process and management of the facilities that represent and reflect their own experiences.

\section{Chuetsu Earthquake Memorial Corridor}

\subsection{Chuetsu Earthquake}

The Niigata Chuetsu Earthquake, which had its epicenter in the Chuetsu region of Niigata Prefecture, occurred at 5:56 pm on October 23rd, 2004. A distinctive characteristic that can be pointed out about this earthquake was that it brought about great destruction in mountainous areas. In particular, following the earthquake, mountains crumbled, roads became blocked, and 61 villages became isolated. The evacuation of all of the villagers from the former Yamakoshi Village was publicized as a representative example of this. In the mountainous areas where there was great destruction, the earthquake served as an impetus for many people to leave the region, and this further spurred depopulation and aging of the population, which had been worsening even before the earthquake. Therefore, an issue central to reconstruction was the matter of achieving sustainability in mountainous areas and, as a pillar of reconstruction, Niigata Prefecture set out to "obtain new sustainability that is full of vitality" for the revitalization phase.

\subsection{Outline of the Chuetsu Earthquake Memorial Corridor}

The Chuetsu Earthquake Memorial Corridor aims to prevent experience of the disaster from fading as time goes by, to the extent possible, leaving sites affected by the disaster as they are. For the corridor facilities, four facilities and three parks were established as places that convey memories of the earthquake, and act as bases for the collection and use of earthquake archives. 


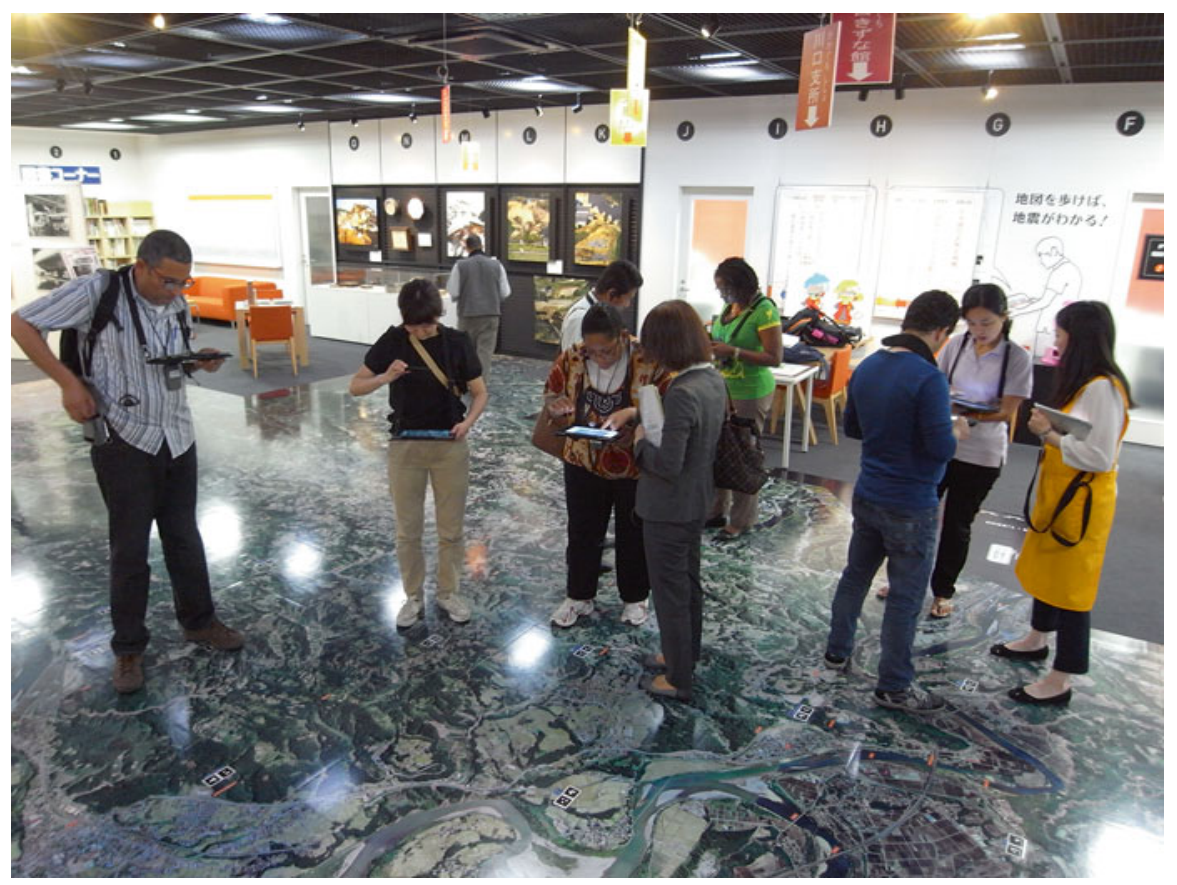

Fig. 2 Nagaoka Earthquake Disaster Archive Center - Kiokumirai (Memories for the Future)

Each of the four base facilities has its own distinctive characteristics. The Nagaoka Earthquake Disaster Archive Center-Kiokumirai (Memories for the Future) (Fig. 2) acts as the gateway to the Chuetsu Earthquake Memorial Corridor, and it is positioned as the core facility of the corridor. It is set up such that people can learn about the earthquake disaster in general here, and learn more detailed information at the other facilities. The Ojiya Earthquake Disaster MuseumSonaekan (Preparedness) (Fig. 3) is in charge of disaster prevention education. This facility conveys lessons learned from the experience of the earthquake in an easyto-understand manner, and with the aim of putting those lessons to use as customary measures, it divides post-disaster life into the four phases of $3 \mathrm{~h}$ post-disaster, 3 days post-disaster, 3 months post-disaster, and 3 years post-disaster, and shows the necessary measures to be taken so that they can be understood in terms of each phase. The Kizuna (Bonds/Ties) Center of Kawaguchi (Fig. 4) plays the part of revealing connections that were born between people (between neighbors, between residents and outsiders, etc.) as a result of the disaster. It not only focuses on past connections that were made at the time of the earthquake, but also relationships that are progressively continuing to develop. The Yamakoshi Restoration Exchange CenterOrataru (My/Our Place) (Fig. 5) plays the part of recounting the path of the history, culture, and reconstruction of the village. While talking about life in the village, voices of the local people recount the path they took to return to Yamakoshi and to 


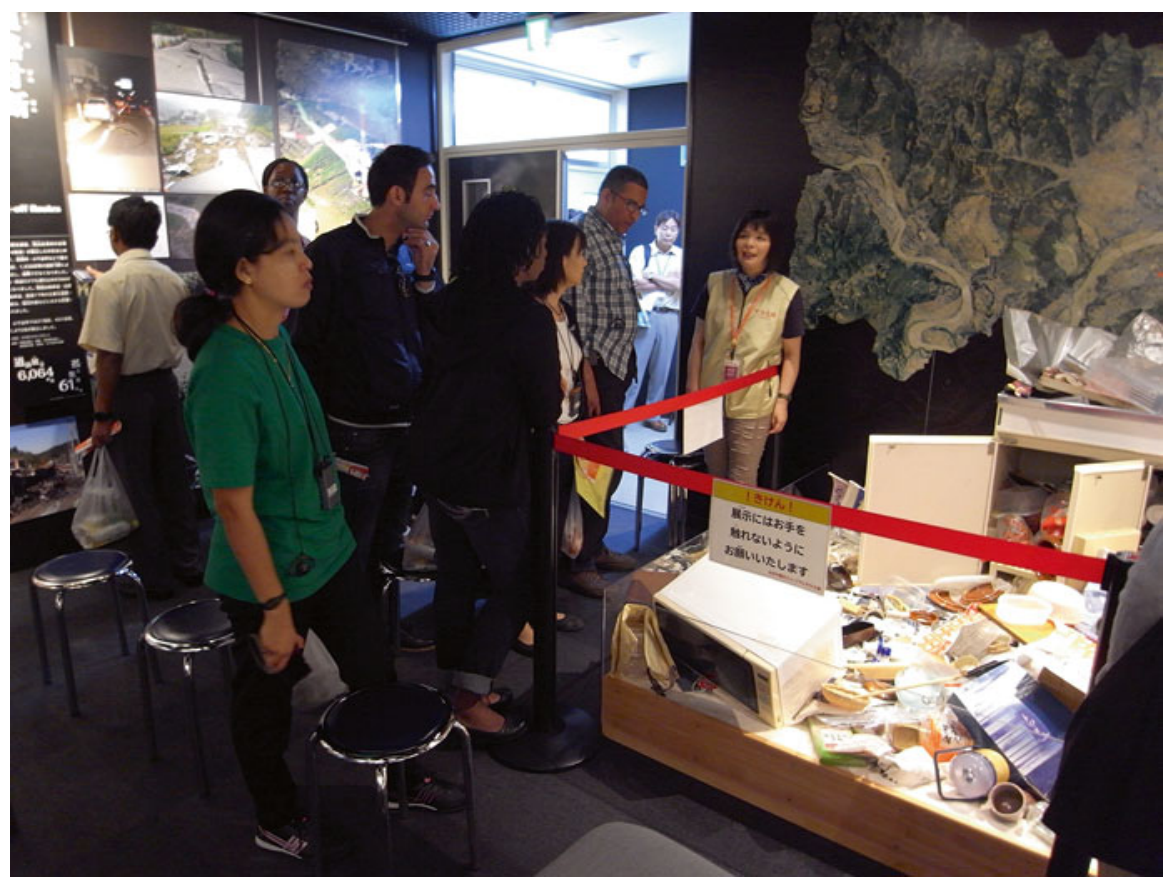

Fig. 3 Ojiya Earthquake Disaster Museum - Sonaekan (Preparedness)

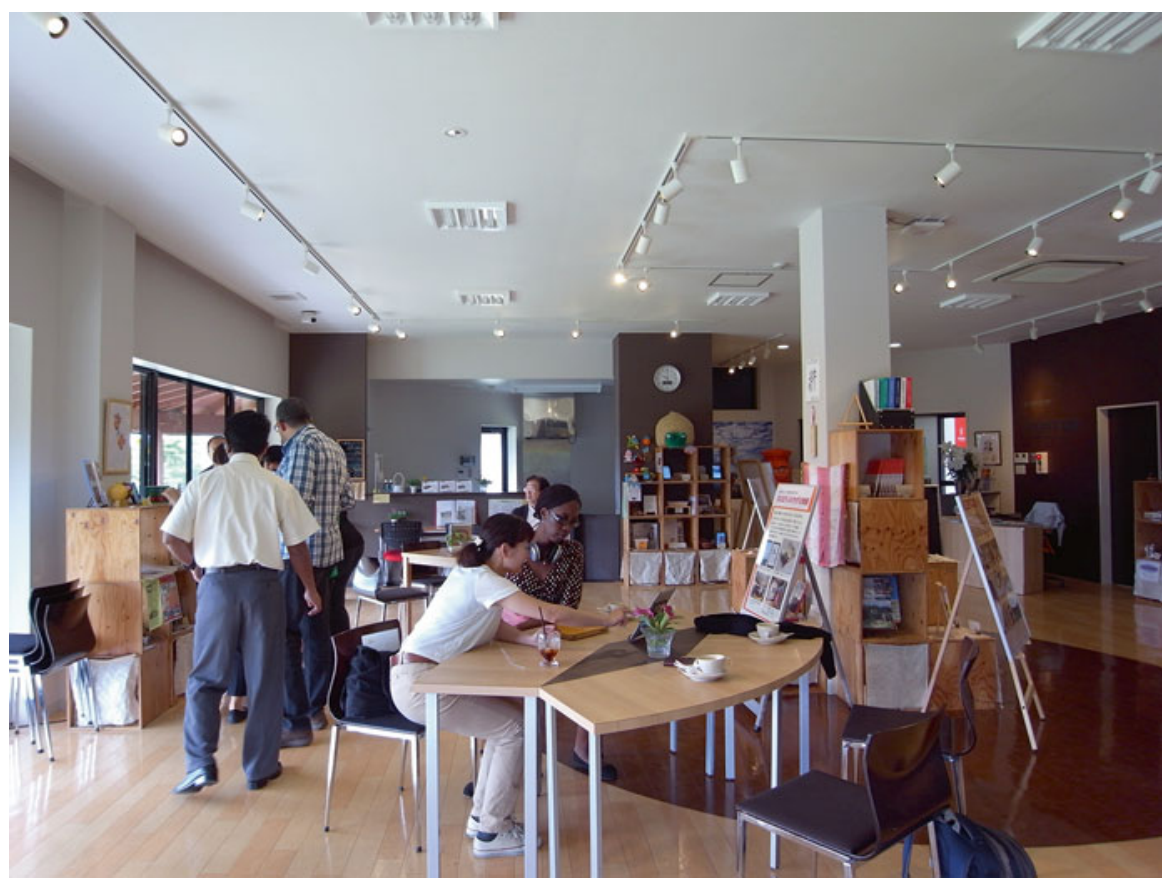

Fig. 4 Kizuna (Bonds/Ties) Center of Kawaguchi 


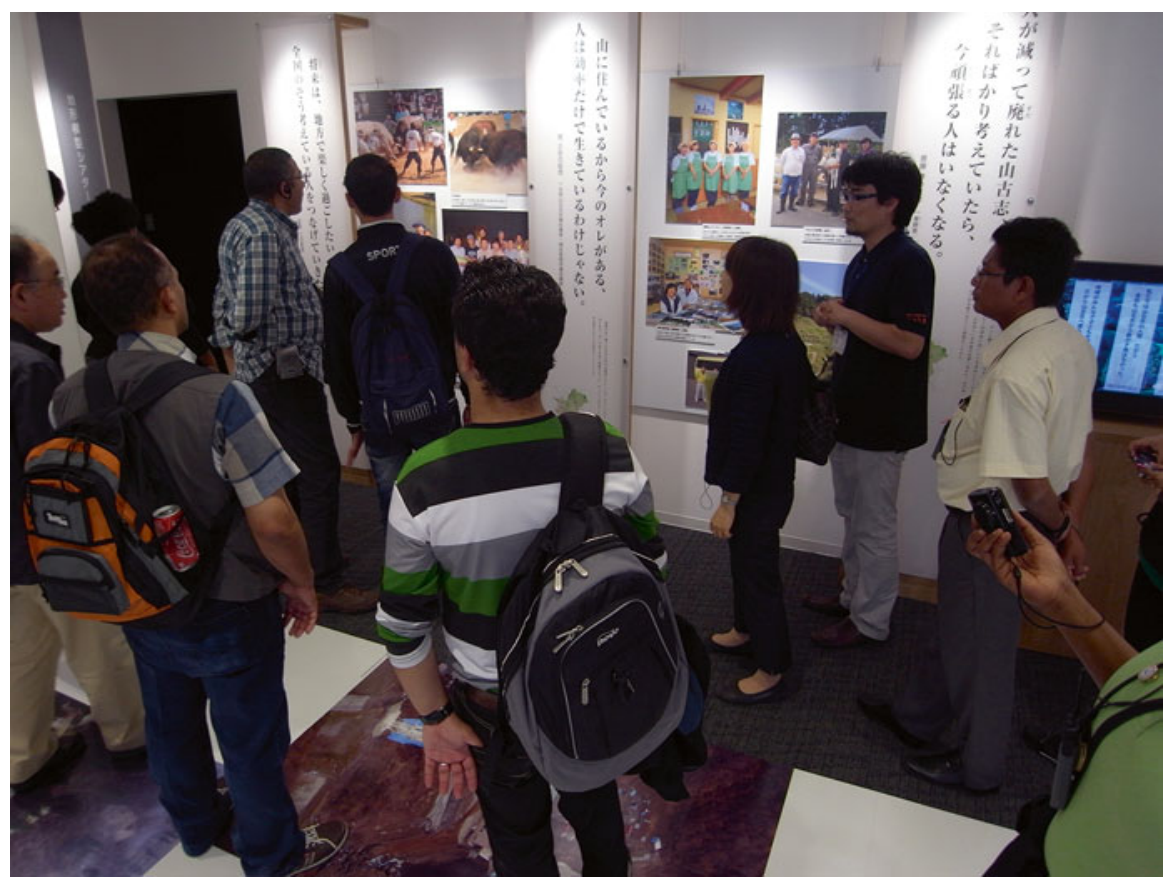

Fig. 5 Yamakoshi Restoration Exchange Center-Orataru (My/Our Place)

revive their hometown, even after being subjected to the extensive destruction of the earthquake.

The three memorial parks are located in places representative of the earthquake. Myoken Earthquake Memorial Park (Fig. 6) was established as a "park for prayer" located near a disaster site where several cars were engulfed in a large-scale landslide. Every year on October 23rd, many flowers are offered to the departed on a flower alter. Kogomo Memorial Park (Fig. 7) was established as a "park for remembering" located near the site of a village that was submerged by a river channel blockage due to the biggest landslide of the Chuetsu Earthquake. The submerged houses still remain as they were at the time of the destruction. The local residents there established and operate an exchange facility called Satomian, where they currently sell local products, such as vegetables, to tourists while they discuss aspects of the disaster and lessons learned. The Epicenter of the Chuetsu Earthquake Memorial Park (Fig. 8) was established as a "park for beginnings" located at the site of the epicenter of the Chuetsu Earthquake. As an event to mark the first anniversary of the earthquake, local residents and other participants, including myself, found the site of the earthquake epicenter using GPS technology. It was located in the center of a terraced rice field. 


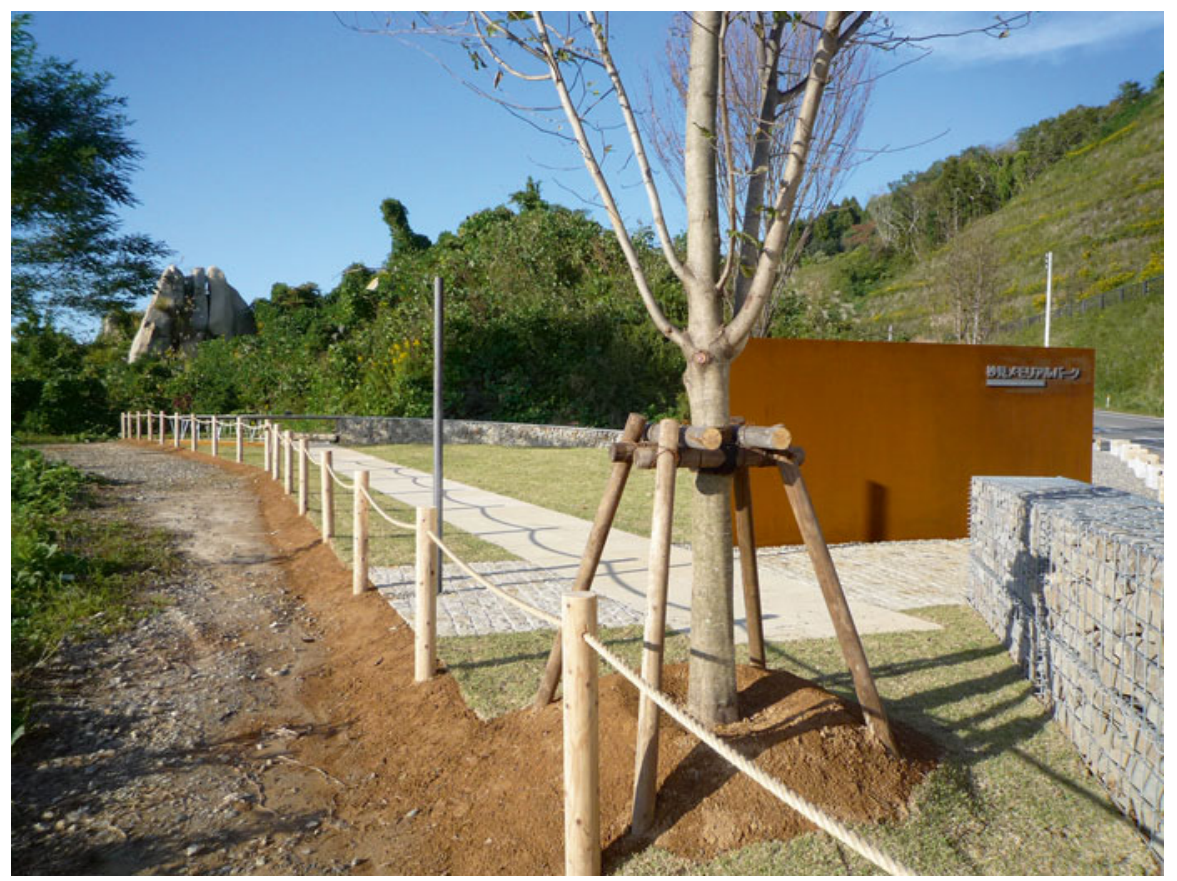

Fig. 6 Myoken Earthquake Memorial Park

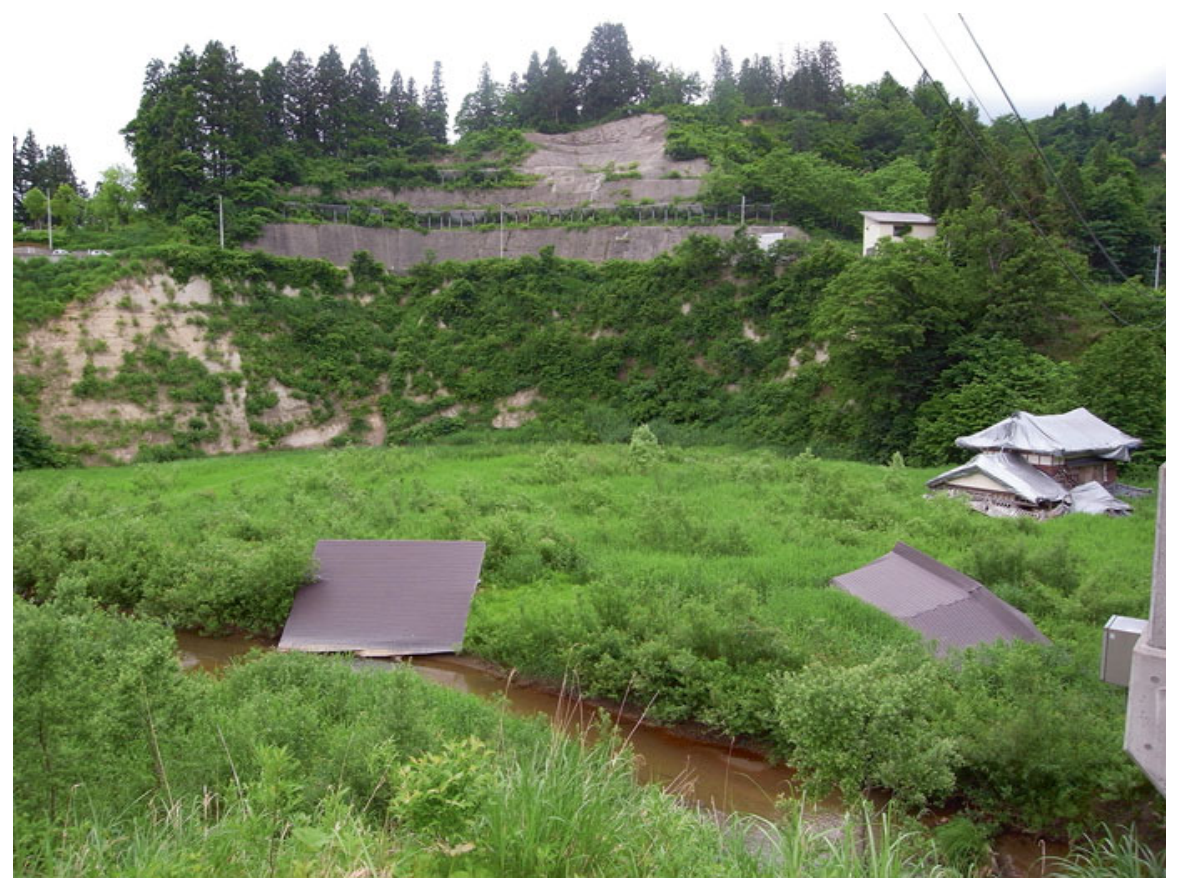

Fig. 7 Kogomo Memorial Park 


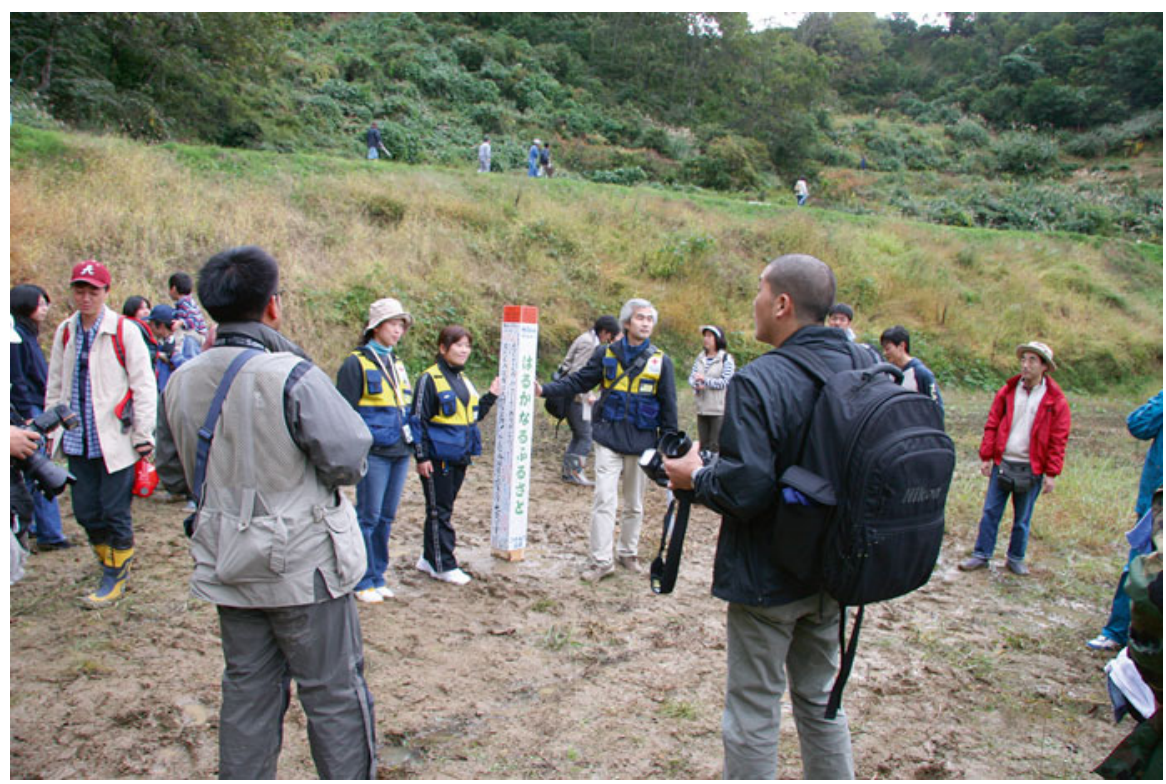

Fig. 8 Epicenter of the Chuetsu Earthquake Memorial Park

\subsection{Resident-Led Initiatives}

Yamakoshi's residents conceived of the Yamakoshi Restoration Exchange CenterOrataru. As the name indicates, the residents actively take part in the management of the Center's exhibition facilities. An NPO founded by Yamakoshi's residents, NPO Chuetsu Disaster Prevention Frontier, is commissioned to manage the facility, and they not only give tours of the building but they also foster storytelling guides who tour all of Yamakoshi, as they convey the story of their earthquake experience and lessons learned. Management of the Kizuna Center of Kawaguchi is also commissioned to an NPO founded by Kawaguchi's residents, the Life Support Echigo-Kawaguchi. At the Ojiya Earthquake Disaster Museum-Sonaekan, storytelling programs, lectures, etc. are carried out through collaboration with an NPO founded by Ojiya's residents, NPO Disaster Prevention Support Ojiya. In this manner, the Chuetsu Earthquake Memorial Corridor functions to collect and disseminate memories of the Chuetsu Earthquake, and local residents are actively involved with its management.

\section{Background to the Establishment of the Facilities}

There are many museums in which citizens carry out volunteer activities or museums that are established by a municipality but total or partial management is privately commissioned, i.e., publicly built and privately operated museums. One significant 
distinctive characteristic of the Chuetsu Earthquake Memorial Corridor facilities is that from the stage at which the establishment of the facilities was under consideration, places were secured where local residents could share their options, and residents have been actively participating in the management of the facilities since their opening.

A distinctive characteristic of the Niigata Chuetsu Earthquake was that it hit mountainous areas where depopulation and aging of the population was already worsening. Due to the earthquake, mountains crumbled, sediment blocked roads and became embedded in rice paddies and reservoirs, and in some cases, terraced rice fields and ponds themselves caved in. At one point, 61 different villages were isolated in a state in which it was difficult for relief supplies to be delivered.

The Chuetsu region is an area that is subject to heavy snowfall and is also an area prone to landslides. Despite the harsh environment, Koshihikari-brand rice is produced on the terraced rice fields created on sloped surfaces formed from landslides, and buyers from places such as China, America, and Europe come to the Chuetsu region seeking Japanese colored carp. It is a land that has bred its own unique culture such as bullfighting, fireworks, and Bon festival dances that vary slightly between each village. However, it was feared that the villages in the mountainous regions affected by the earthquake would further decline by becoming uninhabitable and the residents "descending the mountain" to live in urban areas. The existing decline and aging of the population was in fact exacerbated by this earthquake, which is why Niigata Prefecture adopted "obtaining new sustainability that is full of vitality" as one of the pillars in their reconstruction plans.

In mountainous regions where the decline and aging of the population worsened further due to the earthquake, reconstruction was carried out by first rebuilding individual lives (rebuilding houses and restoring farmlands) and then by rebuilding regional communities. In order to rebuild communities, in addition to restoring infrastructure, shrines and community centers that were the foundation of the community were repaired and rebuilt, events aimed at revitalization were held, and plans for autonomous reconstruction were developed and implemented. Furthermore, exchange programs with outside groups were actively carried out, and community businesses were born, such as farm restaurants and inns jointly managed by the community. These initiatives and the Chuetsu Earthquake Memorial Corridor have created a synergistic effect.

\section{Intermediary Organizations and Reconstruction Fund}

Operation and management of the Chuetsu Earthquake Memorial Corridor is being conducted by the Chuetsu Organization for a Safe and Secure Society. This organization is a public interest incorporated association founded in 2006. This association aims to encourage and support activities related to recording and researching the Chuetsu Earthquake Disaster, while utilizing the research results to create a safe and secure society and to promote disaster prevention and safety industries, by taking advantage of a conglomeration of educational and research institutions in the 
Chuetsu region, through the cooperation and participation of various entities (government, educational and research institutions, companies, and individuals). The Niigata Chuetsu Earthquake Reconstruction Fund established in 2005 is being used as the source of funds for developing the facilities. The Reconstruction Fund is retained under a government reconstruction initiative, and was established with the aim of advancing, over the long term and in a flexible manner, aid and self-support for victims and reconstruction countermeasures in affected areas, and reviving the affected areas into attractive localities. The director of the fund is the governor of Niigata Prefecture. The scale of the fund was 300 billion yen, and operating at an interest rate of $2 \%$ per year, would amount to 60 billion yen over 10 years (Fig. 9).

Since the memorial facilities were viewed as something that would contribute to future disaster response by recording and disseminating the life-rebuilding process, a tool for expressing gratitude for the support received from throughout the nation, and something indispensable to the reconstruction of affected areas, the Reconstruction Fund contributed to the development expenses of the memorial facilities.

The Chuetsu Organization for a Safe and Secure Society acted as a coordinator for connecting support groups, such as the Chuetsu Reconstruction Citizens' Council and specialized institutions like libraries, and residents in affected areas, and it is thought that these connections are also being put to use in the management of the memorial facilities. A portion of the collected materials is currently being exhibited in the Memorial Corridor facilities.

\section{Support by Disaster Reconstruction Fund and Intermediary Organizations}

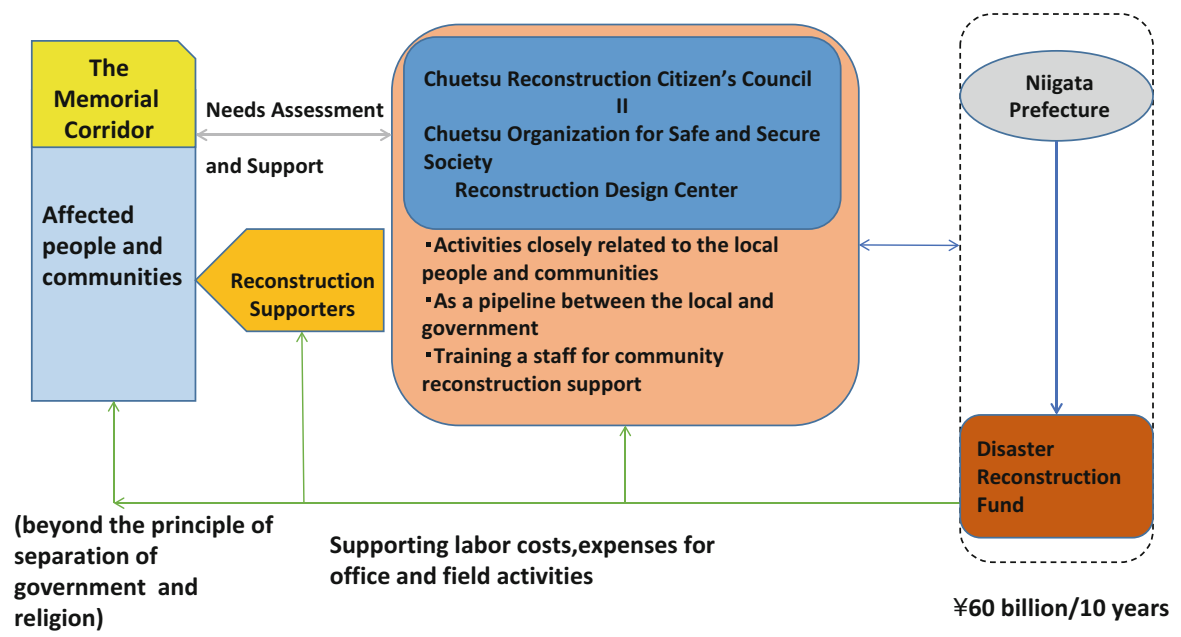

(modified from Aota, Murosaki and Hokugo 2010)

Fig. 9 Support by Disater Reconstructon Fund and Intermediary Organizations (Modified from Aota et al. (2010)) 


\section{Summary}

Interspersing earthquake disaster memorial facilities and the like as a circuit throughout the affected areas, and disseminating information about the earthquake itself and lessons learned, while operating in conjunction with facilities such as roadside rest areas and farm restaurants, lead to the activation of a community in which residents are active players. This serves as a highly suggestive reference case for newly appearing disaster-affected areas, such as those affected by the Great East Japan Earthquake, who are searching for models of post-disaster reconstruction. Moreover, this not only serves as a reference case for reconstruction from disaster but also serves various people, such as administrative officials in charge of regional development, general citizens, and members of volunteer disaster prevention organizations who value connections between neighbors, or even families and small groups of youngsters who want to become acquainted with "mountain life" by interacting with the locals. In response to such needs, the Nagaoka Earthquake Disaster Archive Center-Kiokumirai in the center of Nagaoka City plays the role of introducing facilities and routes in the circuit that can be visited.

Although the Disaster Reduction and Human Renovation Institution in Kobe is a sort of centralized information facility that one can visit to learn a lot about the Great Hanshin-Awaji Earthquake, through circulating multiple facilities, the Chuetsu Earthquake Memorial Corridor introduces the disaster conditions of the regions where each of the facilities is located and the efforts that residents made toward reconstruction, and with this as a backdrop that makes up the region, the history, culture, and issues are also introduced. There are many spots scattered throughout the route circulating those regions that bring visitors into contact with the life of the people and records and memories of the disaster.

The Mt. Unzen Disaster Memorial Hall in the Shimabara Peninsula of Nagasaki Prefecture is also an example constituting a field museum comprising multiple facilities that convey the story of the volcano eruption disaster, such as the Sand Arrestation and Future Museum, the Heisei-shinzan Nature Center, and Onokoba Primary School, which was burned in the pyroclastic flow. However, there is little information about the whole field museum and not many opportunities for exchange with the locals. The Chuetsu Earthquake Memorial Corridor, on the other hand, is a facility where visitors can receive guidance from the Nagaoka Earthquake Disaster Archive Center-Kiokumirai as the gateway, can have the route they visit customized, and can learn about disaster and disaster response in the context of the culture and history of the region through interacting with locals at the destinations they visit.

\section{Notes}

1. The Reconstruction Design Council in Response to the Great East Japan Earthquake, Towards Reconstruction: Hope beyond the Disaster (2011) p. 2.

2. Yamakoshi Village was merged into Nagaoka City Municipality in April 2005.

3. The three pillars of reconstruction are "creative restoration" (restoration phase), "new sustainability full of vitality" (revitalization phase), and "creation of new norms for daily life beyond disaster reconstruction" (development phase). Third Niigata-Chuetsu Earthquake Disaster Reconstruction Plan. 
4. Five Reconstruction Funds were launched before the Great East Japan Earthquake 2011: Unzen-dake Eruption (1991.9 , \109 billion); Hanshin-Awaji Earthquake (1995.9 , 1900 billion); Chuetsu Earthquake (2005.3 , 1305 billion); Noto Peninsula Earthquake (2007.8 , 150 billion); and Chuetsu-Oki Earthquake (2007.10 , \120 billion). Aota et al. (2010), p. 4.

5. In the original estimate, development expenses alone were expected to be approximately 4.1 billion yen. However, the Nagaoka Earthquake Disaster Archive Center is a rented facility and the other three facilities were able to use existing buildings under a free loan, so the total amounted to 2.8 billion yen. Of that, it was decided in a Board of Directors meeting in May 2010 that the fund would contribute 2 billion yen.

Open Access This chapter is distributed under the terms of the Creative Commons AttributionNonCommercial 4.0 International License (http://creativecommons.org/licenses/by-nc/4.0/), which permits any noncommercial use, duplication, adaptation, distribution and reproduction in any medium or format, as long as you give appropriate credit to the original author(s) and the source, provide a link to the Creative Commons license and indicate if changes were made.

The images or other third party material in this chapter are included in the work's Creative Commons license, unless indicated otherwise in the credit line; if such material is not included in the work's Creative Commons license and the respective action is not permitted by statutory regulation, users will need to obtain permission from the license holder to duplicate, adapt or reproduce the material.

\section{References}

Aota, Ryosuke, Murosaki, Yoshiteru, and Hokugo Akitoshi. 2010. Study on the promotion of disaster reconstruction with local initiative, on the basis of the relationship between disaster reconstruction fund and Intermediary Organization. Journal for the Institute of Social Security Society No. 12. http://isss.jp.net/isss-site/wp-content/uploads/2013/08/2009-004_cd1.pdf. Accessed 5 Nov 2015.

The Reconstruction Design Council in Response to the Great East Japan Earthquake. Towards Reconstruction: Hope beyond the Disaster. http://www.cas.go.jp/jp/fukkou/english/pdf/ report20110625.pdf. Accessed 5 Nov 2015.

Thomas, Vinod. 2014. Towards disaster and climate resilience, Presented at the International Scientific Conference on Fisheries and Aquatic Sciences.http://www.slideshare.net/adbevaluation/upv-iloilo-keynote-disaster-and-climate-resilience-21-oct. Accessed 5 Nov 2015. 


\section{Part V \\ Museums and International Cooperation}




\title{
JICA's Cooperation in Museum Construction and Capacity Building of Human Resources
}

\author{
Shinichi Yoshihara
}

\begin{abstract}
Japan International Cooperation Agency (JICA), an Incorporated Administrative Agency, assisted developing countries in various fields as the executive agency for Japanese Official Development Assistance (ODA). JICA provides assistance through technical cooperation, loan aid, and grant aid in an integrated manner. The Agency also assists developing countries through dispatch of volunteers, emergency disaster relief, and citizen participatory cooperation. Examples of assistance to museums in Asia are given in this text. However, in comparison with other sectors such as infrastructure, health, and education, projects and training for museum development remain small scale.
\end{abstract}

\section{Preface}

Japan International Cooperation Agency (JICA), an Incorporated Administrative Agency, has been assisting developing countries in various fields as the executing agency of Japanese Official Development Assistance (ODA). JICA provides assistance with three principal schemes, Technical Cooperation, ${ }^{1}$ Loan Aid, ${ }^{2}$ and Grant $\mathrm{Aid}^{3}$ in an integrated manner. In addition to these schemes, JICA also assists developing countries through Dispatch of Volunteers, Emergency Disaster Relief, and Citizen Participatory Cooperation (Fig. 1).

In spite of its smaller scale compared to other sectors such as infrastructure, health, and education, JICA has been continuously implementing projects and training for museum development in developing countries utilizing the three principal schemes and Citizen Participatory Cooperation in cooperation with relevant organizations such as the National Museum of Ethnology.

This paper will explain the purpose of assistance and past achievements, representative projects, and foresight in terms of museums.

\footnotetext{
S. Yoshihara $(\bowtie)$

Japan International Cooperation Agency (JICA), Nibancho Center Building 5-25,

Niban-cho, Chiyoda-ku, Tokyo 102-8012, Japan

e-mail: Yoshihara.Shinichi@jica.go.jp
} 

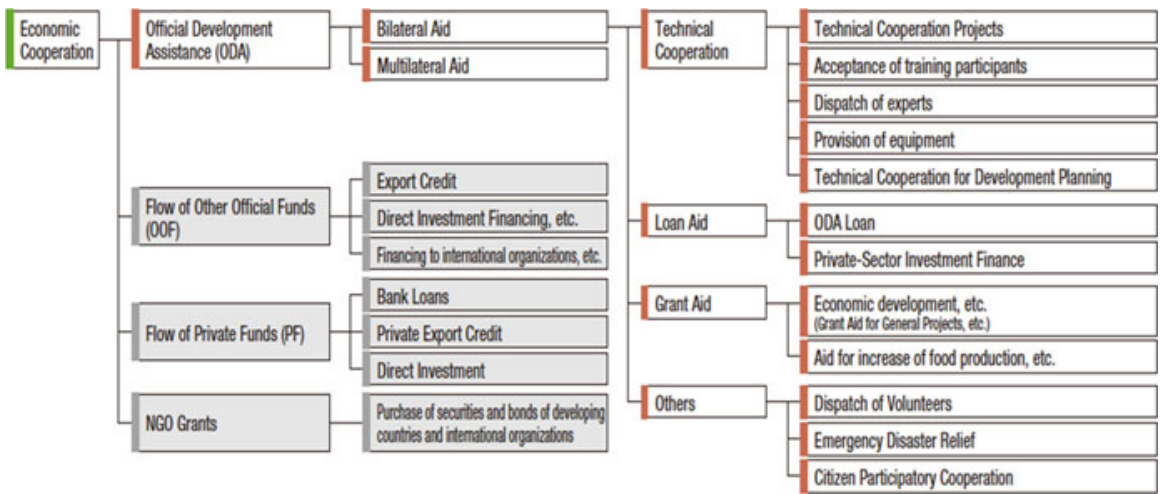

Fig. 1 Economic cooperation and ODA (Source: JICA Annual Report)

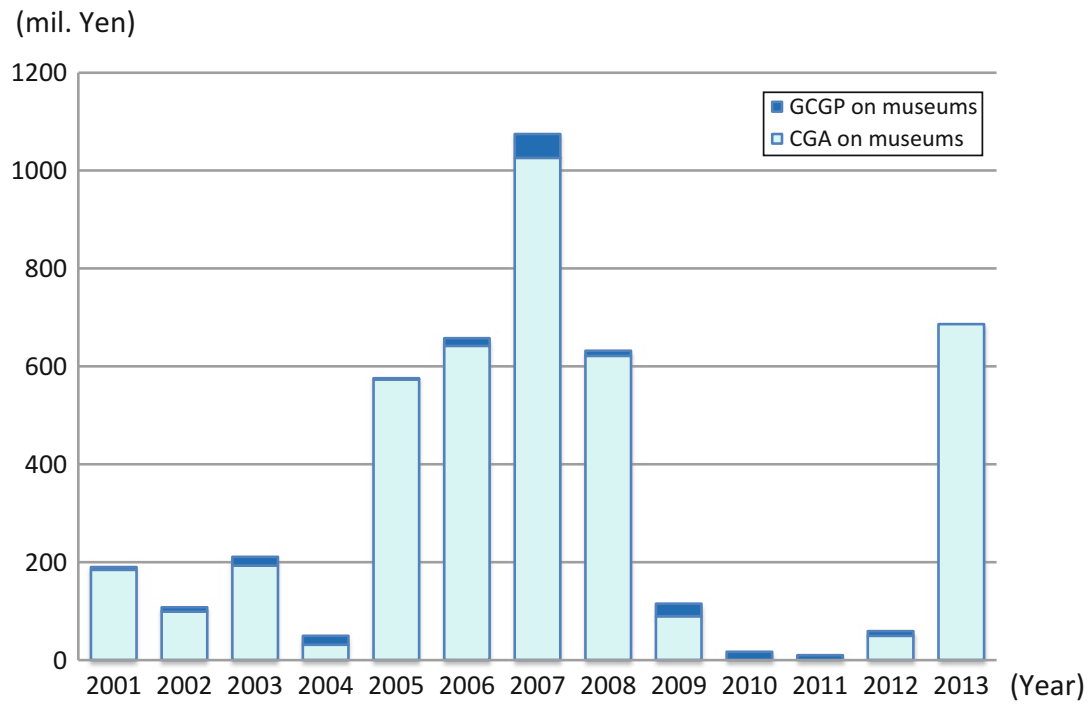

Fig. 2 Assistance to museums through GCGA and GACGP (from 2001 to 2013)

\section{Purpose of Assistance to Museums and Past Achievements}

Assistance to museums by Japanese ODA has mainly been implemented through General Cultural Grant Assistance (GCGA) started from 1975 and Grant Assistance for Cultural Grassroots Projects (GACGP) started from 2000 to contribute to the preservation of cultural heritage and to promote culture and higher education in developing countries. The number of past achievements is shown in Figs. 2, 3, and 4. The highest is Middle East, and Asia, Latin America, and Europe follow. 


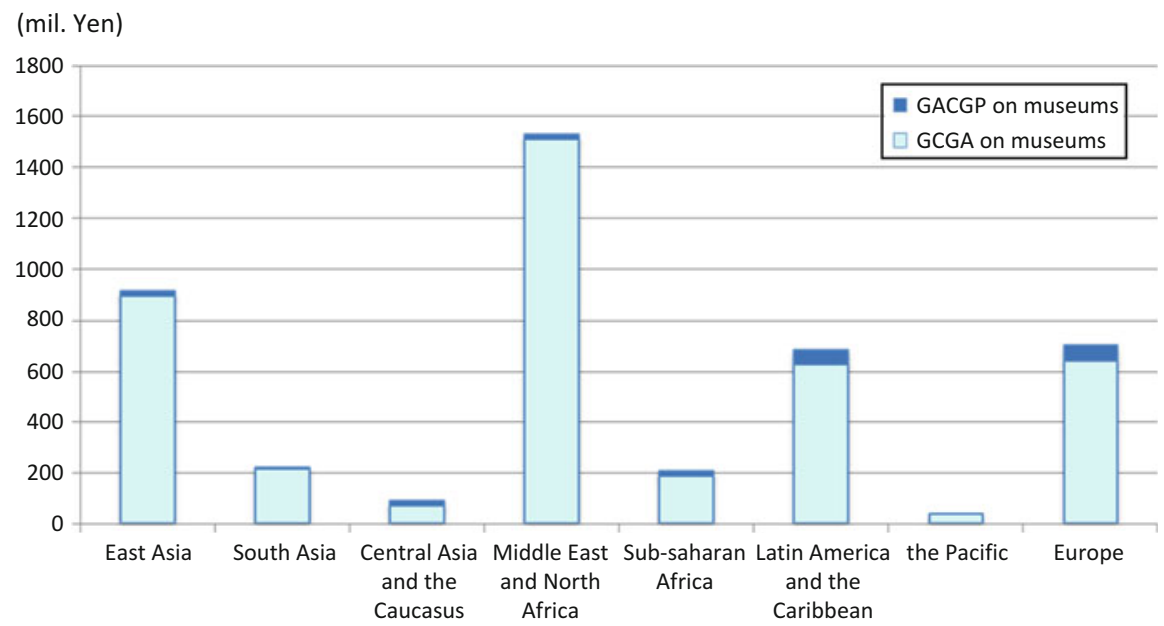

Fig. 3 Assistance to museums through GCGA and GACGP by region

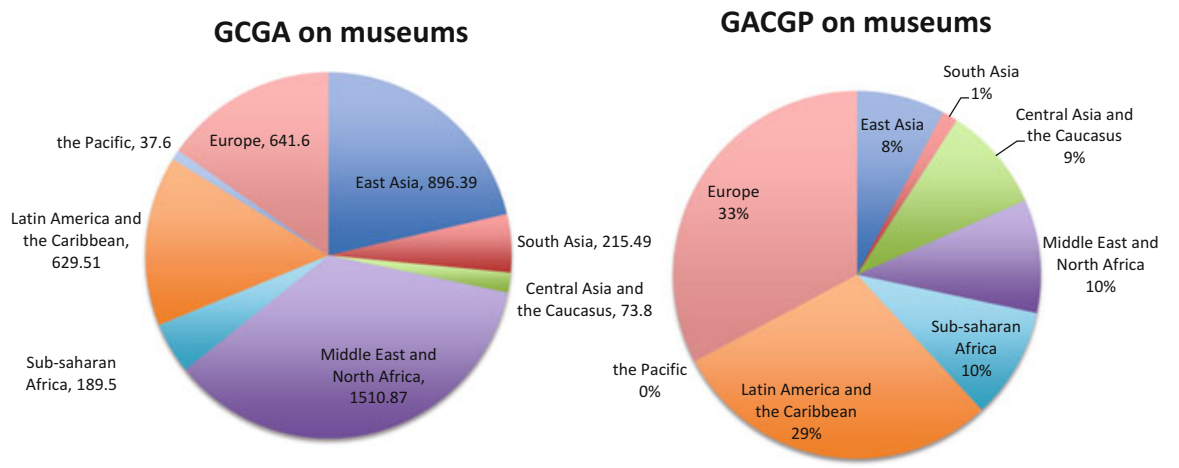

Fig. 4 Assistance to museums through GCGA and GCGP by region (from 2001 to 2013)

In recent years, some projects have been implemented with other schemes such as Technical Cooperation, ODA Loans, and JICA Partnership Programs. They further aim to promote museum-oriented development of a region and/or tourism, contributing to increase in job creation and income level among the local people. 


\section{Representative Projects of Assistance to Museums}

\subsection{Comprehensive Museology (Group- and Region-Focused Training)}

The most comprehensive and historical assistance to museums is the training program "Comprehensive Museology" conducted by the National Museum of Ethnology, Japan (Minpaku) and Lake Biwa Museum. The training course, which has been improving its contents and implementation structure since its commencement in 1994, consists of lectures and practical work for about 3 months.

The objectives of this training program are to provide participants with fundamental knowledge of museum management, as well as to share with them experiences and knowledge of museum activities in Japan. In order to achieve the aim, the program consists of a full set of opportunities for the participants to attend lectures by Japanese experts from various fields, and also to visit museums and cultural sites throughout Japan. Some special training courses, which participants can select according to their own interests, are also offered as options.

In addition to improving the management of museums and professional skills of participants from various countries, the training program also promotes sharing of knowledge and experiences among the participants from developing countries and the Japanese experts who deliver the lectures in the program. A total of 190 people from over 50 countries have completed the program so far and the learning network built up in this training program has expanded to become world-wide as a result of 21-year-long assistance.

\subsection{JICA Partnership Program}

As another approach to meeting the various needs of developing countries, JICA has been financing the "JICA Partnership Program (JPP)," implemented by Japanese museums to utilize their accumulated knowledge and experience in assistance activities for developing countries.

\subsubsection{Community Promotion Featuring Museums and Environmental Improvement around Cultural Assets (JICA Partnership Program, 2008-2011)}

In 2006, Fukuoka Prefecture signed a friendship agreement with Bangkok City, Thailand to strengthen cooperation and exchange information in various fields including the economy, environment, culture, and tourism. With this background, Bangkok requested assistance from Fukuoka with preserving cultural properties and also utilizing them for regional development, which led to Kyusyu National Museum (KNM)'s two consecutive projects under the JICA Partnership Program. 
First of all, KNM conducted training programs from 2008 to 2010 at the Bangkok National Museum (BNM) in Thailand and KNM in Japan, focusing on preservation and utilization of cultural properties, as well as strengthening the contribution of museums to local society.

In the second project, from 2010 to 2011, KNM organized an exhibition at the BNM co-sponsored by the Agency for Cultural Affairs, government of Japan. Through the preparation work for the exhibition, Thai experts worked together with Japanese experts, which led to the creation of an enticing exhibition.

This project contributed to strengthen the relationship between the two museums, and in 2012, KNM entered into an academic exchange agreement with the Fine Arts Department of the Ministry of Culture, Thailand.

\subsubsection{Cambodia-Okinawa "Peace Culture" Museum Cooperation (JICA Partnership Program, 2009-2015)}

The assistance needs of Tuol Sleng Genocide Museum (TSGM) in Cambodia regarding museum operations and management fit the experiences of the Okinawa Prefectural Peace Memorial Museum (OPPMM), which had been considering assisting overseas museums conforming with their establishment concept: passing onto future generations the historic lessons and conveying messages to the peoples of the world. ${ }^{4}$

OPPMM has been implementing two consecutive projects under the JICA Partnership Program.

The first project has started in 2009 and OPPMM provided technical transfer to TSGM in the field of collection, preservation, and exhibition of objects and museums activities on education.

In 2012, OPPMM and TSGM co-organized a special exhibition entitled "Two Peace' Peace Creation Exhibition by Two Peace Museums" at Tuol Sleng Genocide Museum as an achievement of 3-year cooperation. This is a remarkable example of a technical transfer at a museum from a museum that has the same exhibition theme of. Through the continuous cooperation between the two museums, the stage of the project is transitioning from technical transfer of curators to strengthening of museum management in the second project from 2012.

\subsection{Representative Projects in Asia}

\subsubsection{Cooperation to Sigiriya, Sri Lanka (Various Schemes, 2006-2010)}

The Sri Lankan government set the target of developing projects in the cultural and tourism sector as an important national policy, and the Japanese government implemented comprehensive and integrated support through various cooperation schemes. Japan/JICA offered ODA loans for upgrading the access road from the main 
highway to the Sigiriya area and for building facilities such as toilets and a spiral stairway in the Sigiriya Ruins, while it provided assistance for the procurement of display equipment for the Sigiriya Museum by GCGA and dispatched volunteers for promotion of the tourism industry in the surrounding area.

Considering the Sigiriya Museum to be an important tourist-attracting facility in the region, JICA also implemented the Technical Cooperation "Project for the Development of Culture-Oriented Tourism in Sigiriya" that aimed at, and succeeded in, strengthening and enhancing the role of Sigiriya Museum in tourism activities, leading to tourism development in the region by providing technical assistance for, for example, the lectures on management of the museum, making a tourism promotion plan, and tour guide training.

\subsection{Representative Projects in the Middle East}

\subsubsection{Tourism Promotion Through Museum Activities, Jordan (Technical Cooperation, 2004-2007)}

Tourism is one of the major industries in Jordan, and Japan/JICA has been assisting the promotion of this sector through development of facilities and technical transfer. JICA carried out a study on "National Tourism Development Strategy and Policy" between 1994 and 1996, and proposed future projects including the establishment of four major museums in Jordan. Based on this study result, Japan offered an ODA loan for promotion of tourism by construction of road and tourism facilities such as museums in 1999.

Parallel with this, JICA dispatched volunteers and short-term experts as well as accepting Jordanians for training in Japan. In the course of cooperation, the needs for improving museum management were ascertained.

In this context, JICA implemented the Technical Cooperation Project "Tourism Promotion through Museum Activities" providing capacity development assistance for museum management, collection, and display, of objects to the four model museums built by the Japanese ODA loan: National Museum, Karak Archaeological Museum, Dead Sea Museum, and Historic Old Salt Museum. As a result of this project, counterparts became able to make long-term plans, produce a newspaper, and conduct educational and local activities.

The cooperation with Minpaku in this project made it successful and had a positive impact on all target museums.

\subsubsection{Project for the Conservation Center in the Grand Egyptian Museum (Technical Assistance Related to Japanese ODA Loan, 2008-2016)}

With the assistance of the National Research Institute for Cultural Properties, Tokyo, JICA has been implementing a project providing technical transfer such as Preventive Conservation, Conservation, Conservation Science, and also management to the 
Grand Egyptian Museum Conservation Center (GEM-CC) affiliated with the Grand Egyptian Museum, which is currently under construction with support of a Japanese ODA loan.

In Phase 1 (2008-2011), building an accurate database as well as a department in charge of it was the main activity. In addition to this, JICA also conducted several training programs that were of high priority for GEM-CC.

In Phase 2 (2008-2016), JICA has planned 25 different kinds of training. A total of 85 training programs were conducted and 1036 GEM-CC staff members participated in total by December 2014.

\section{Foresight}

As mentioned above, Japan has been supporting museums of various countries through ODA. It is notable that JICA has the potential to connect overseas and Japanese museums. The experiences, knowledge, and networks gained through implementation of projects are expected to be utilized for further development of museums that promote the attractiveness of each region around the world.

\section{Notes}

1. Technical Cooperation draws on Japan's technology, knowhow, and experience in nurturing the human resources who will promote socioeconomic development in developing countries.

2. Loan Aid supports the efforts of developing countries to advance by providing these nations with the capital necessary for development under long-term and substantially lower interest rates than commercial rates.

3. Grant Aid, which is an assistance method that provides necessary funds to promote socioeconomic development, is financial cooperation with developing countries with no obligation for repayment.

4. Source: Website of OPPMM.

Open Access This chapter is distributed under the terms of the Creative Commons AttributionNonCommercial 4.0 International License (http://creativecommons.org/licenses/by-nc/4.0/), which permits any noncommercial use, duplication, adaptation, distribution and reproduction in any medium or format, as long as you give appropriate credit to the original author(s) and the source, provide a link to the Creative Commons license and indicate if changes were made.

The images or other third party material in this chapter are included in the work's Creative Commons license, unless indicated otherwise in the credit line; if such material is not included in the work's Creative Commons license and the respective action is not permitted by statutory regulation, users will need to obtain permission from the license holder to duplicate, adapt or reproduce the material. 


\title{
Museums and Community Development: With Special Reference to Zambian Cases
}

\author{
Kenji Yoshida
}

\begin{abstract}
The museum is not only a storage place for tangible objects of the past, or a destination for tourists, it is also a base for the accumulation and dissemination of local culture, and for creating people's pride in or identity to the community. Only when people have pride in themselves and their own culture, can they challenge and overcome various difficulties. Examples of movements in Africa, especially those in Zambia where the author has been working for more than 30 years, clearly demonstrate that the museum, an institution for constructing cultures, can also be appreciated from the viewpoint of community development. The identity museums to be created should be open-minded and those that admit cultural diversity, otherwise it will result only in creating a nationalistic ideology. The networking of museums, both nationally and internationally, is thus essential.
\end{abstract}

\section{Introduction}

When we look back, controversy had been growing over ethnographic exhibitions in museums in the 1980s and 90s. Ethnographic museums throughout the world had long been focusing on cultures extraneous to the country in which the museum is located. Museums were likely to approach this task from their vantage point of their own cultures. However, in the 1980s and 1990s, people of the world who had long been the subjects of ethnographic exhibitions in large-scale museums became more aware of their own cultures and histories, and thus begun to protest against this prevalent one-sided approach to exhibitions of ethnic cultures. Under the circumstances, it became common for large-scale museums to have collaborative relationships with the people who are represented in exhibitions, in organizing exhibitions or constructing databases of their collections. Involvement of people in the activities of those large-scale museums promoted people's awareness of their own culture and history, and there is now a vigorous movement in every corner of the globe to build local or community museums to present on site the culture of the community.

\footnotetext{
K. Yoshida $(\square)$

National Museum of Ethnology, Senri Expo Park, Suita, Osaka 565-8511, Japan

e-mail: yoshidak@idc.minpaku.ac.jp
} 
While globalization has been prevailing in every aspect of human life, the significance of the museum as a device that is rooted in each local community, inherits its culture, and furthermore, newly constructs it, has been recognized more widely.

\section{Museum Training Courses}

Along with an increase in the number of museums in the world, demand for the opportunity to acquire the knowledge or techniques required for managing museums has become more vociferous year by year. However, there are only limited occasions for acquiring substantial knowledge and techniques related to museums in an integrated manner. Under such circumstances, a series of museum training courses, which has been carried out by the National Museum of Ethnology, Japan (Minpaku) in collaboration with the Lake Biwa Museum as a project sponsored by Japan International Cooperation Agency (JICA), is a very unique attempt in the world.

A total of ten trainees participate in the course every year from all over the world. As for this year's course that started on the 18th of April and finished on the 25th of July 2014, there were ten trainee participants from four countries: Jamaica, Myanmar, Egypt, and Palestinian Authority. The subjects of this 4-month course range from the history of the museum, its latest trends, methods of collection management, conservation science, exhibition design, database construction, museum education, and development of museum goods to crisis management. All of these subjects are mainly undertaken in the workshop style focusing on discussion or practice rather than giving unilateral lectures. Lecturers of this course are researchers and curators of museums in Japan such as Minpaku or the Lake Biwa Museum, and other experts are also invited according to each specialized field. We would ask a professional of an art-transporting company to give a lecture in a workshop for packing art objects, and an expert individual who is in charge of marketing for business practices. After the 2011 Tohoku Earthquake and Tsunami, training in risk management and disaster prevention has been intensified. Training trips are also on the program during the course term to visit not only museums in the Kansai area but also the museums in the Hokkaido, Tokyo, and Hiroshima areas.

There is no model that is applicable to all aspects of museum management.

It is our planned scheme that the participants search for something that is applicable to the museum activity of their own country through directly experiencing the various activities that Japanese museums provide. As far as I know, there is no such occasion on a worldwide level as this course that comprehensively serves to provide training in a wide variety of museum activities.

While the course provides them with an opportunity for training, the "trainees" are actually curators who are well experienced and have been active on the frontlines of their country's museums. Thus, in reality, this training opportunity becomes like a forum where our experiences in Japan meet their experiences, so that we are able to learn from each other and share new knowledge and recognition. 


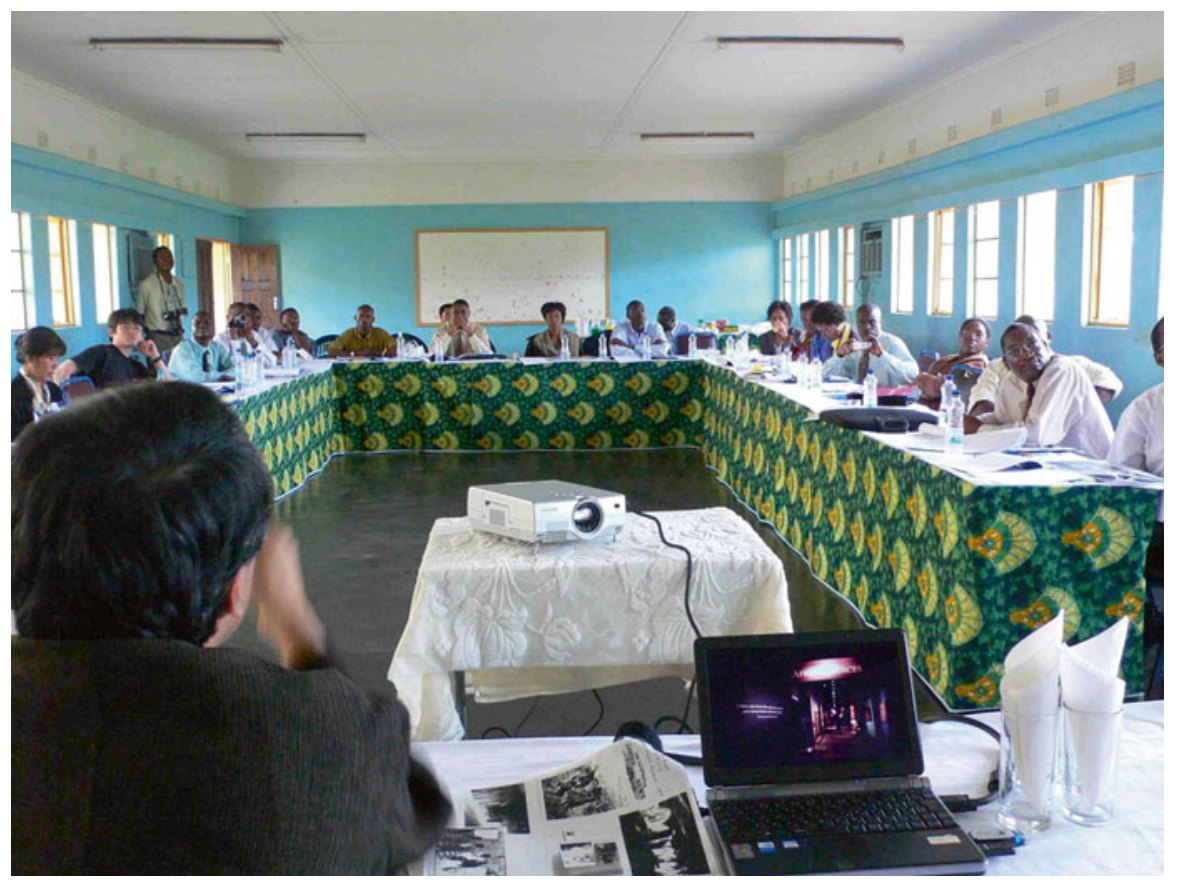

Fig. 1 Museology workshop in Livingstone 2005

We have accepted 216 trainees from 56 countries and regions in the last 21 years, considering the outcome of the current "Comprehensive Museology" course (which started in 2012 and its predecessors, i.e., the "Intensive Course on Museology" that lasted between 2004 and 2011) and the original "Museum Technology Course," which started in 1994 and lasted up to 2003. From next fiscal year 2015, we plan to renovate the course by placing more weight on the role of museums as an instrument of community development, and we will start the course under the new title of "Museums and Community Development." The global networks connecting the museums that have been constructed through these courses are a great fortune for all of the people and organizations involved in the course.

\section{Development of the Training in Japan}

But there is more than that. As for Zambia, by 2004, we had received six trainee participants in the courses. In Zambia, a workshop entitled "Museology Workshop in Livingstone 2005" (Fig. 1) was organized by the six former participants targeting museum curators of the country who did not have a chance to come to Japan for the period 4-9, December, 2005. It delighted us in that, in this way, the achievement of the training acquired in Japan can be further developed in each country and lead to unique activities of the locals. The initiative taken by the former participants in the 


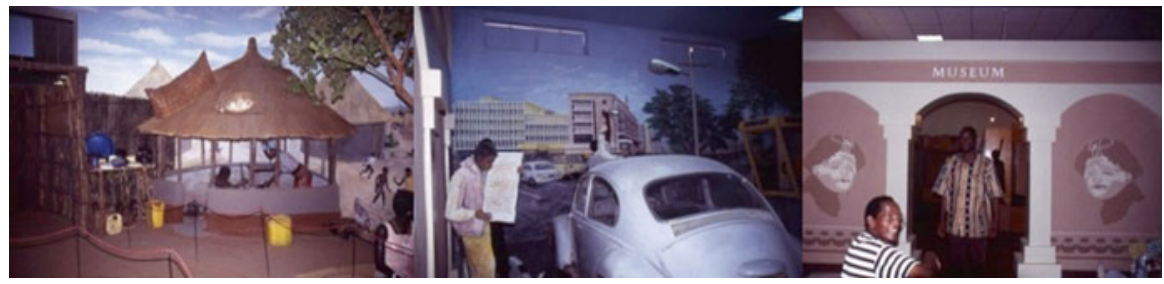

Fig. 2 New ethnographic gallery at the Livingstone Museum: village life (left), urban life (middle), and a corner called "Museum" (right)

museum training courses was highly appreciated by the JICA regional office, and from 2006 to 2008, a more intensive workshop on museum activities focusing on a particular subject each year (exhibition design in 2006, collection conservation in 2007, and documentation including the construction of a database and film making in 2008) was organized as a follow-up program to the training course. Each year, former participants in the course played the role of instructor, and we, Japanese museum specialists, also joined the workshop as facilitators. And the follow-up workshop really functions as an opportunity where a unique museology based on local specifics is jointly created by all participants. Needless to say, the current project "New Horizons in Asian Museums and Museology" which led by Professor Sonoda, has exactly the same intention and can be considered to create a unique museology in each Asian country. The form of development that we have aimed at from the very beginning of the project of the training course has finally been attained.

Visible results of the training course are now appearing in Zambia. Some temporary exhibitions on local communities at the Lusaka National Museum were installed by using the so-called carton-box technique, which was introduced during the training course in Japan. It is a form of technology that makes use of simple materials like carton boxes to make partitions and display walls for exhibitions. Achieving maximum efficiency by using minimum equipment is always a basic item on the training agenda.

The new ethnographic exhibition recently completed at the Livingstone Museum is a unique reflexive exhibition. In refurbishing the ethnographic gallery, the museum divided the gallery into three parts: Village Life, Urban Life, and a corner called "Museum" (Fig. 2). Visitors are invited to enter into the reconstruction of a village setting first, where a bicycle and plastic water tanks are placed in front of thatched huts, then to another reconstruction of urban life settings where familiar scenes in a town for visitors are reconstructed by combining paintings, photographs, and real objects, and finally to a corner called "Museum" where a typical ethnographic exhibition is developed by displaying objects visitors are actually using in their daily life. Through this exhibition, visitors are unconsciously led to review their own choice of where to live either, in a village or in town, which is a crucial question that all people in Zambia are facing, and are also invited to rethink about the nature of a museum that is showing their daily utensils. In this exhibition, visitors are not only visitors per se, but became active players in the exhibition. By being juxtaposed with reconstruction of village and urban settings, a typical ethnographic exhibition in the museum has become another reconstruction of a 
museum setting, all of which shed new light on visitors' experience either in a village, in a town, or in a museum. The curators who were engaged in realizing this exhibition said to me that they were inspired by the exhibition to which they were introduced during the course in Japan, that is "Images of Other Cultures" held at Minpaku in 1997, where the British Museum's old galleries and kiosks and roadside shops in Europe, Papua New Guinea, and Japan were reconstructed. In fact, I am the one who curated the exhibition. They say they digested some concepts of the "Images of Other Cultures" exhibition and created their new ethnographic gallery. It seems to me that this exhibition at the Livingstone Museum can be considered as a new type of reflexive exhibition that has been developed uniquely in Zambia by digesting their experience in Japan (Yoshida and John Mack 2008).

\section{Creation of Festivals and Local Museums}

Perhaps there is a particular reason that Zambian museums, or more precisely Zambian museum professionals, are now so acquisitive of knowledge and techniques in museology. It is not because of my involvement.

In Zambia, there have been few festivals organized based on a whole ethnic group. One of the few examples of this sort is kuomboka, or Royal Barge Festival, of the Lodzi people. Having been inspired by such a big-scale festival, in 1980, a ceremony called nchwala where the first harvest of the year is brought to the King was revived among the Ngoni people (Fig. 3). Following the Ngoni, a neighboring

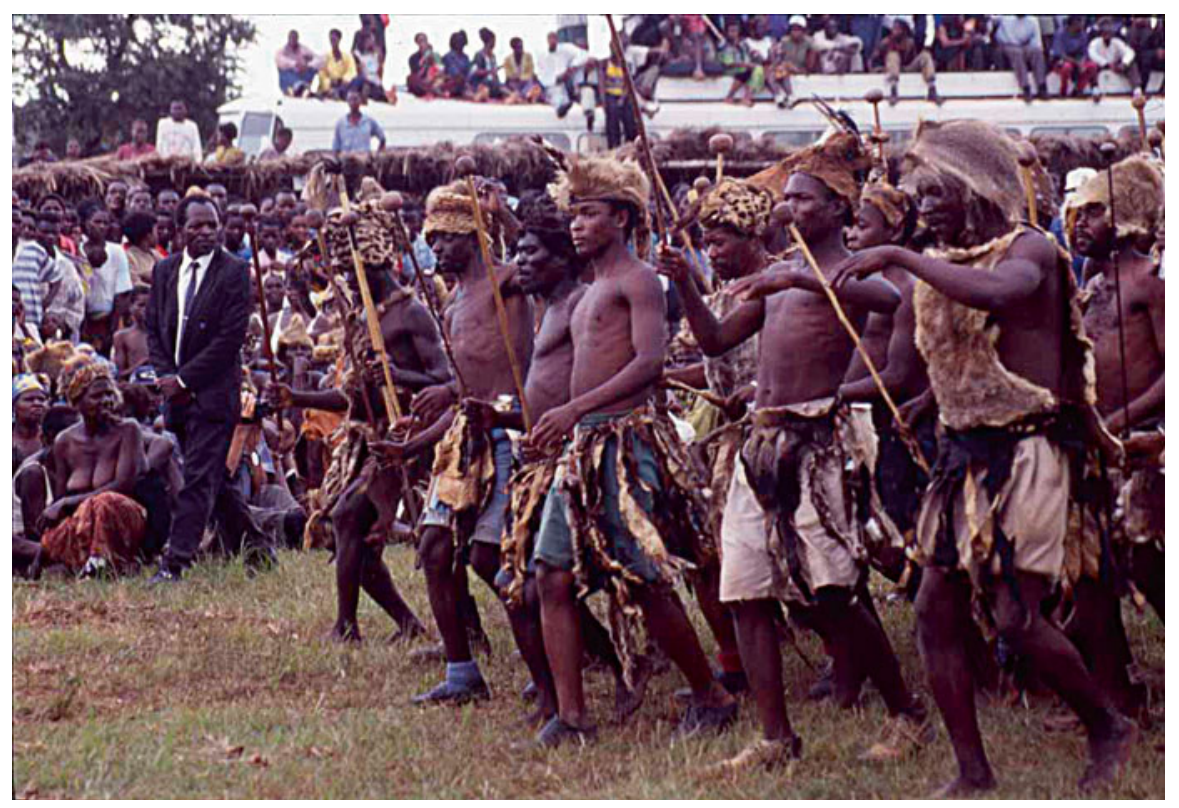

Fig. 3 Nchwala ceremony of Ngoni people. 1999 


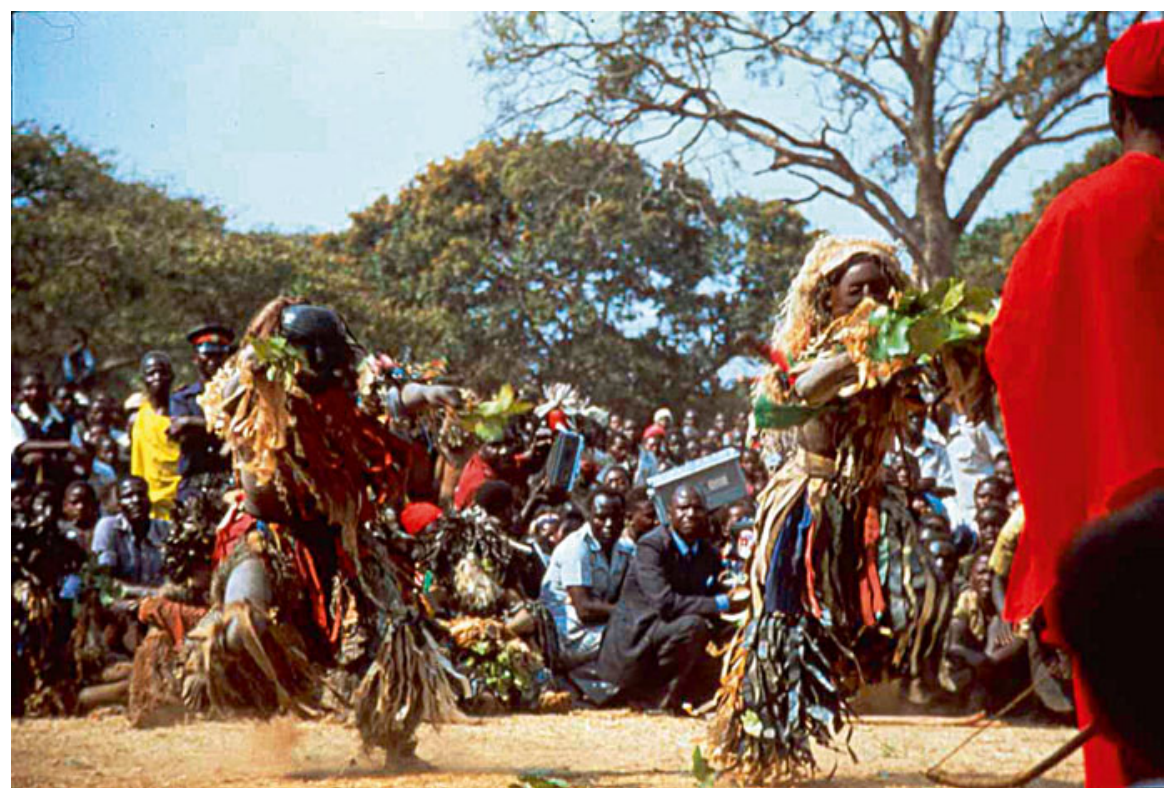

Fig. 4 Kulamba ceremony of Chewa people. 1984

ethnic group named Chewa created a harvest festival called kulamba in 1984, based on an old custom of annual tribute to their King (Fig. 4). Stimulated by these movements, yet another ethnic group in the region, the Nsenga, invented a rain-calling ceremony called twimba in 1988, by combining various old customs (Fig. 5). It is noteworthy that the purposes and dates of the ceremonies are well differentiated so that they do not overlap each other. The Nchwala of the Ngoni is to celebrate the first harvest of the year, and is thus held in the midst of the rainy season. The Chewa's kulamba is a harvest festival, and is held in the depths of the dry season. The twimba of the Nsenga is a rain-calling ceremony, and is held at the beginning of the rainy season. Since then, the movement of creating ethnic festivals is spreading over the whole country under similar slogans like "Let's start our tradition," and now almost all major ethnic groups, which number 73, have got their own annual festivals. Why are they differentiated in date and meaning? Some chiefs and kings explained by saying unanimously, "Otherwise, our own ceremony would not be well covered on TV, and we would also lose an important occasion for lodging appeals to the President and his ministers." The central government actually supports these movements by providing transport for audiences, and by sending representatives like ministers and in some cases the President himself to each festival.

In retrospect, there are not many options for various ethnic groups to proclaim their identity by means of festivals while getting along in harmony with others than to "revive" each ethnic group's festival in a short period. It was indeed a way of avoiding particular groups becoming prominent in society. 


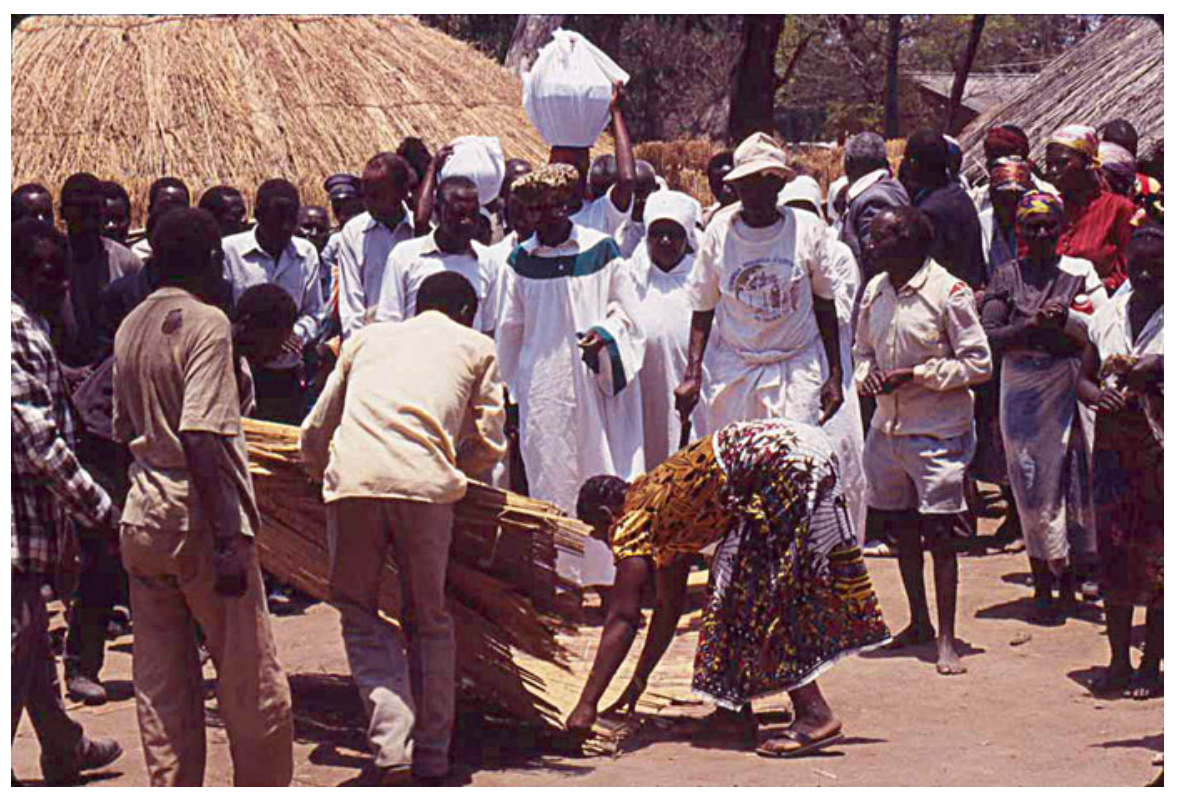

Fig. 5 Twimba ceremony of Nsenga people. 1999

In the 1990s, having created festivals, each group started planning to build its own museum to show its cultural heritage. Some have already been established, most of which are located at the very sites of the annual festivals. The Nayuma Museum built by the Lodzi people in 1986 is a pioneering museum in the trend (Fig. 6). The Choma Museum in Choma in the Southern Province, which is dedicated to the Tonga community, can also be mentioned in this context (Fig. 7).

Another example is the Moto Moto Museum, which was originally established by a Catholic Father, Jean Jacques Corbeil. He built an ethnographic collection that includes objects used in girls' initiation ceremony called chisuingu while he was working in Bemba land (Corbeil 1982). The collection was donated to the national government and the museum became one of the national museums in 1974. But because of the character of its collection, the museum is nowadays playing the role of a community museum for the Bemba people (Figs. 8 and 9).

Yet many other museums are now under construction or contemplation. Among them is a museum called Nsingo Hall in Ngoni land. The Ngoni people are now trying to convert the former municipal hall into their own community museum.

As for the Chewa people, with whom I have been carrying my fieldwork for more than 30 years, their masked dance called gule wamukulu (Fig. 10), together with another masked dance in Zambia, that is, the makishi dance of the Luvale people (Fig. 11), was registered in 2005 as Intangible Cultural Heritage by UNESCO. After the registration, the Chewa people, or more precisely, the Chewa Traditional Council 


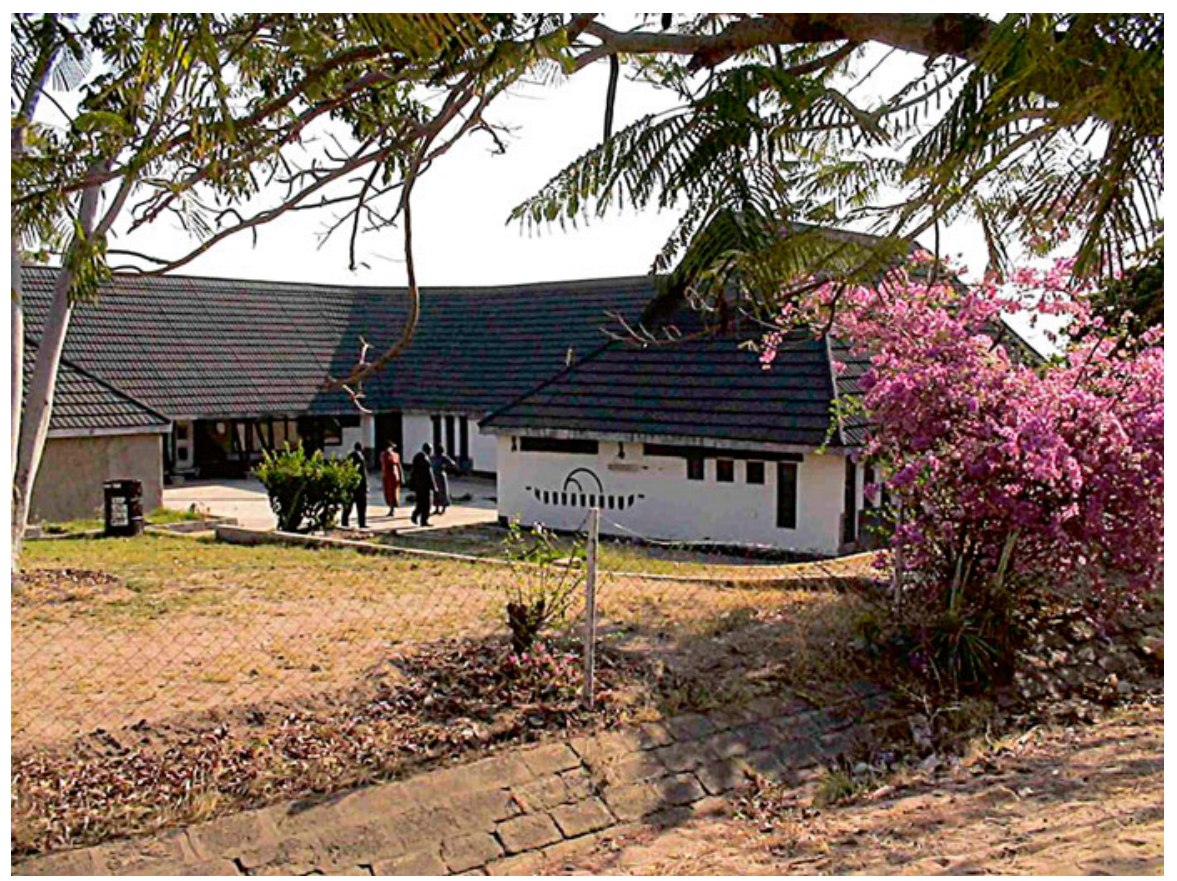

Fig. 6 Nayuma Museum in Mongu

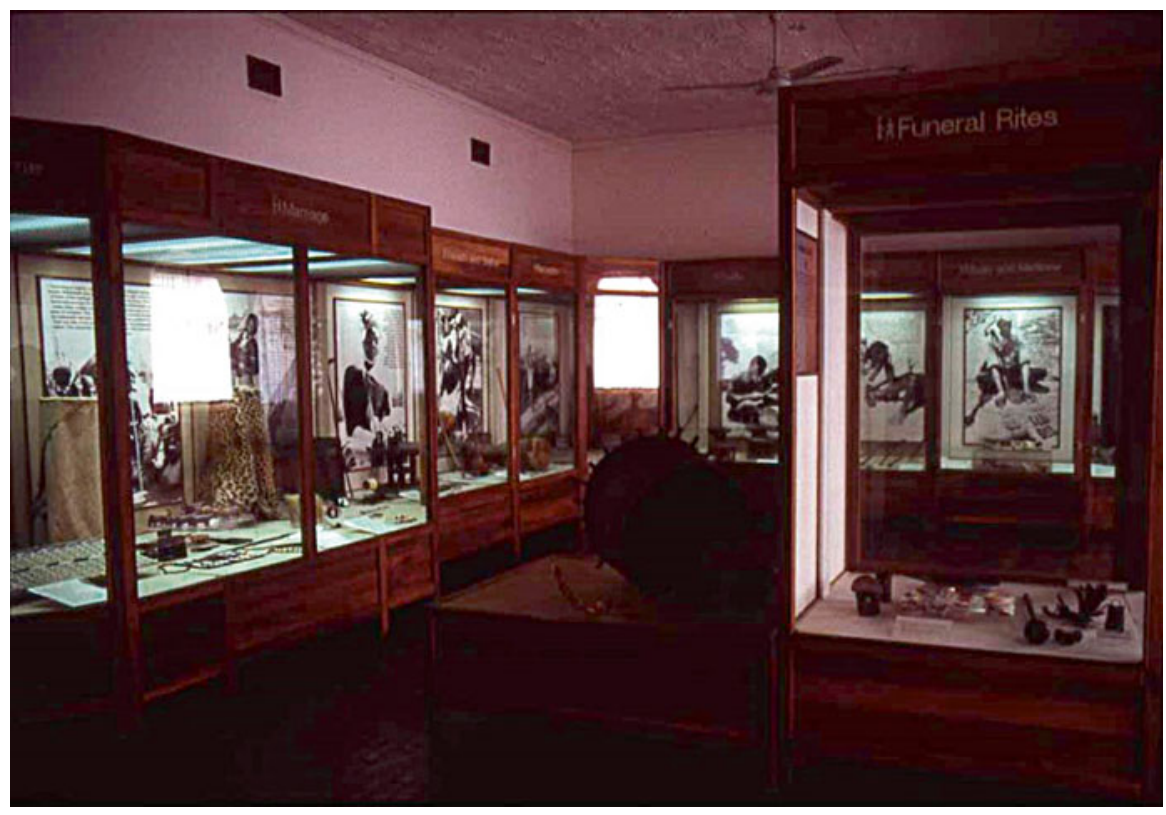

Fig. 7 Choma Museum in Choma 


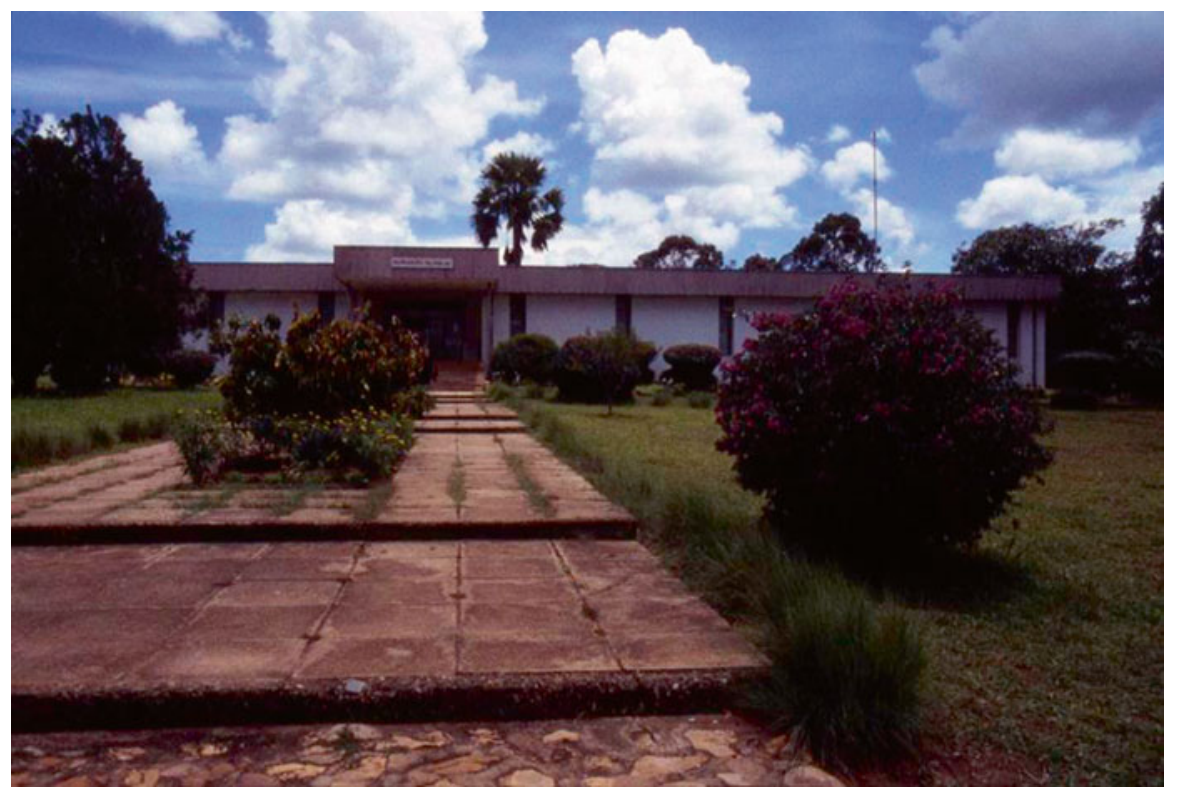

Fig. 8 Moto Moto Museum in Mbala

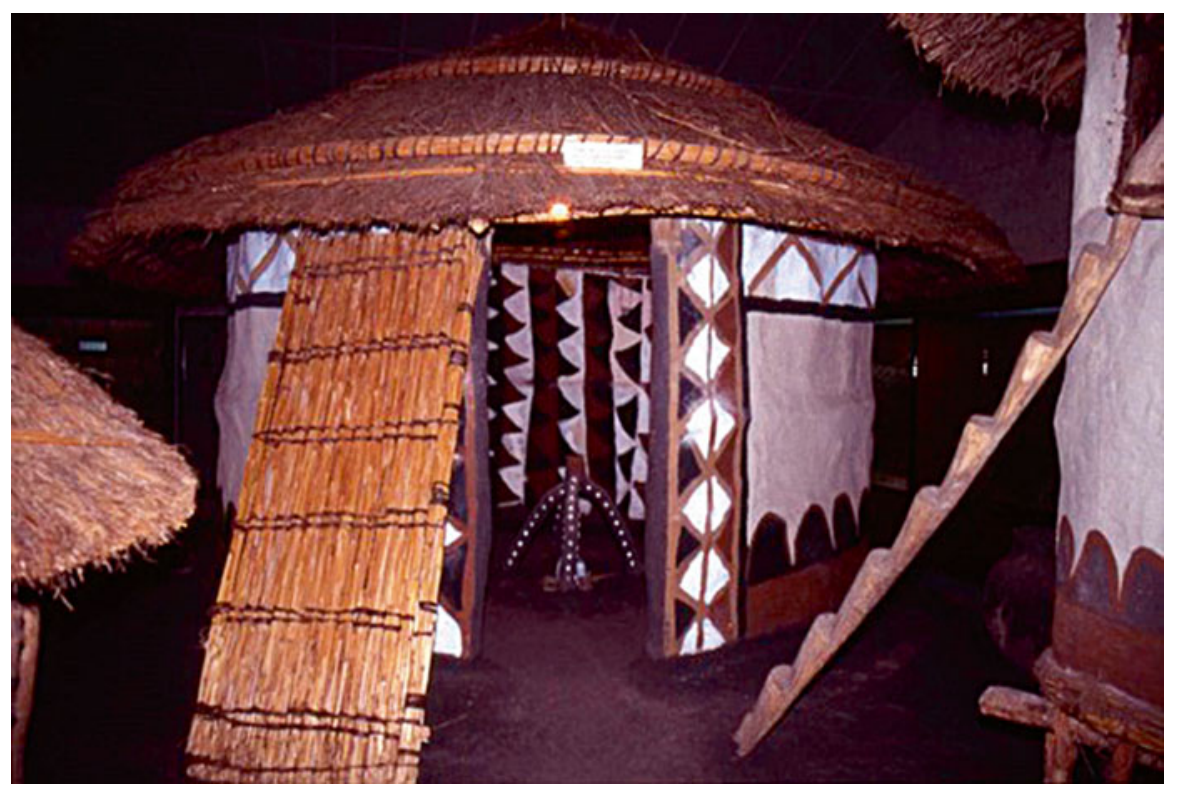

Fig. 9 Reconstructed chisuingu girls' initiation hut in the Moto Moto Museum 


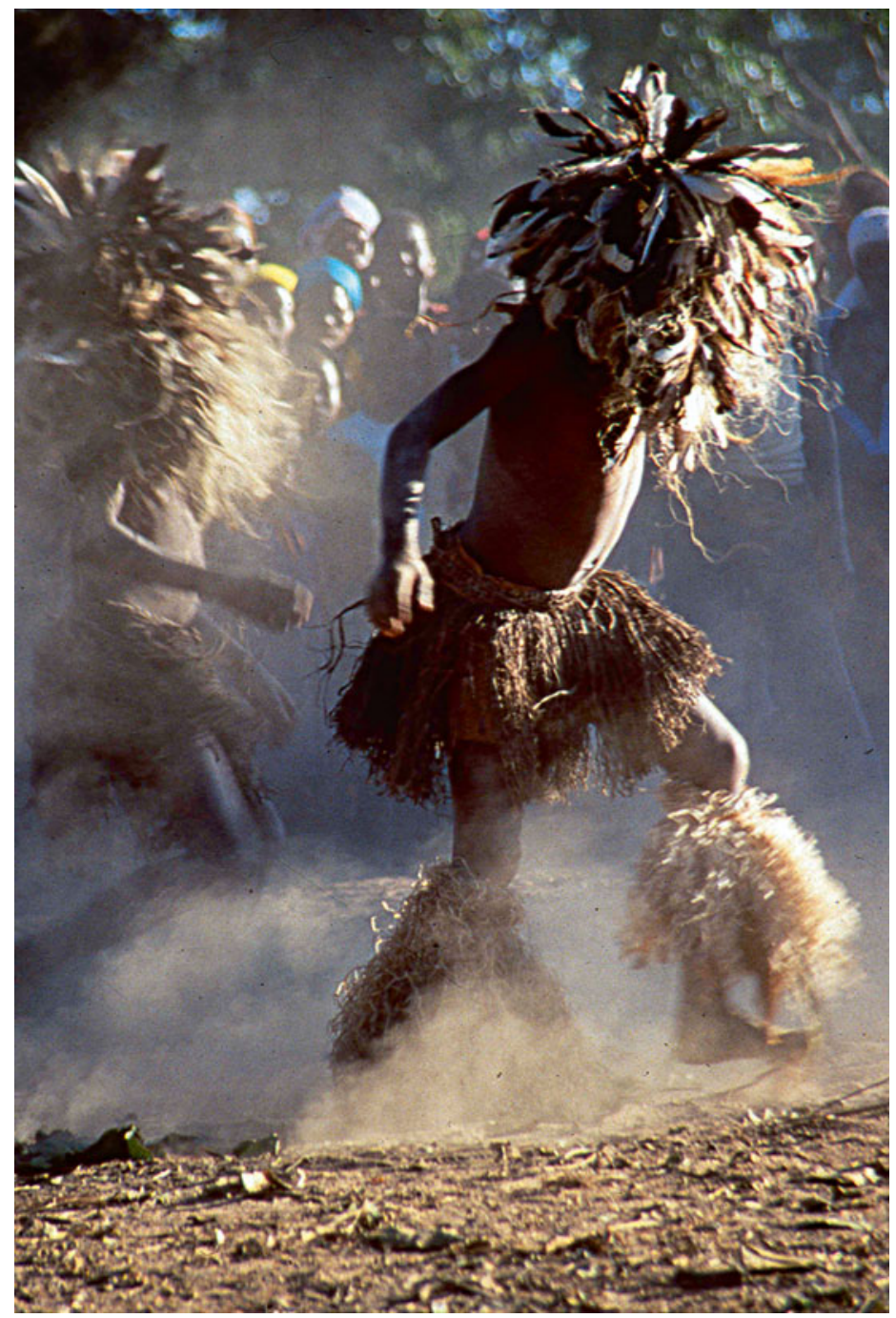

Fig. 10 Gule wamukulu dance of Chewa people

that was established at the time of the first kulamba ceremony in 1984 decided to create a museum at the site of the kulamba ceremony. Though the building is not yet completed, the plan is well underway. A similar movement is also going along among the Luvale people. When I started my fieldwork among the Chewa, it was scarcely known that the Chewa people has a masked-dance tradition (Yoshida 1993). When I think of those days, I feel I am living in a completely different age.

It is noteworthy that the target visitors of these museums are people of the local communities rather than tourists, and that the museums seek to strengthen people's 


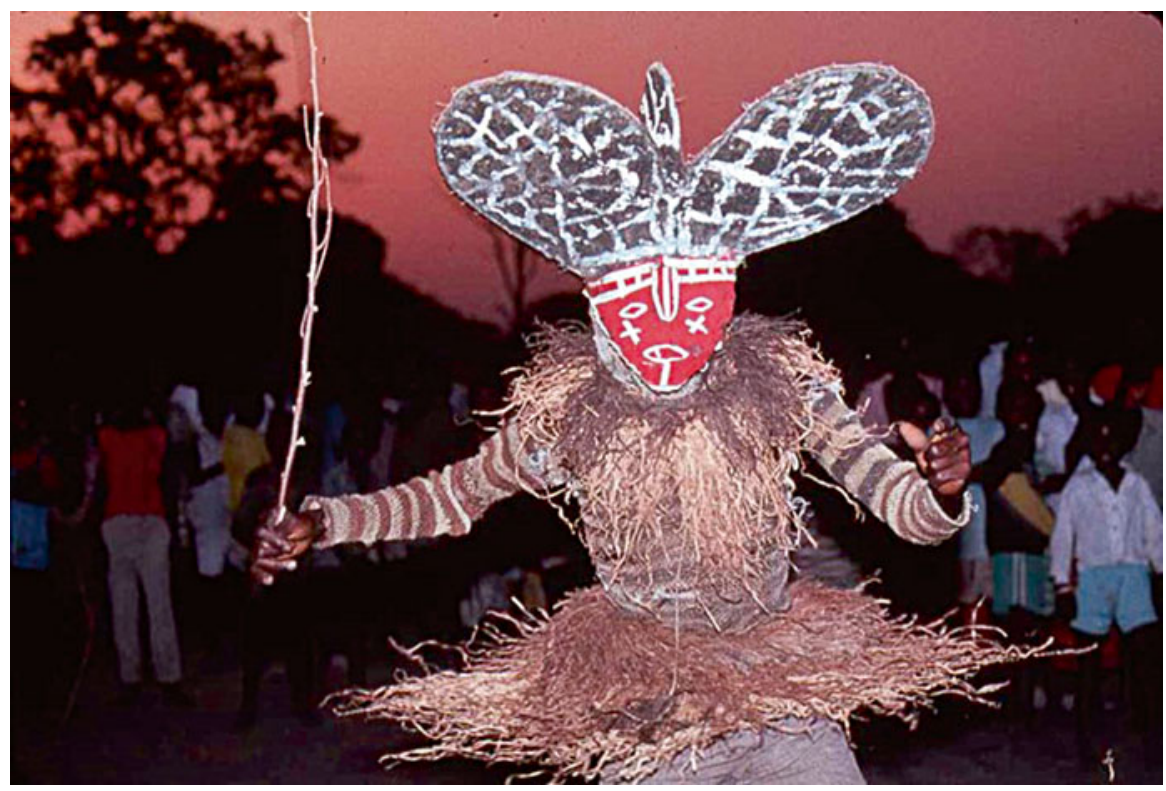

Fig. 11 Makishi dance of Luvale people

pride in their culture and to transmit their traditional culture to a younger generation. The notion of the museum is, however, quite new to the most of the local people. People are finding their own way of creating their museums.

Out of these endeavors, some notable activities are also emerging. Moto Moto Museum, which I introduced above as a community museum for the Bemba people, launched an outreach project to prevent HIV infection in their surrounding areas. Some pieces in their collection, which were used for traditional education during girls initiation ceremony called chisungu, were displayed and used for providing villagers, especially women, with information about prevention of HIV infection.

Another museum, the Livingstone Museum (Fig. 12), which again I referred to above, held an exhibition entitled "What we have been told about Independence" (Fig. 13), which was brought to fruition by collecting reports written by school children of what they had been told by their parents and grandparents about Independence. This exhibition gave people of the local community an opportunity to re-discover their historical heritage, and led to the development of some touristic spots.

In these ways, the museum is now playing the role of instrument for the development of communities. The museum, an institute of constructing cultures, can also be appreciated from the viewpoint of community development. 


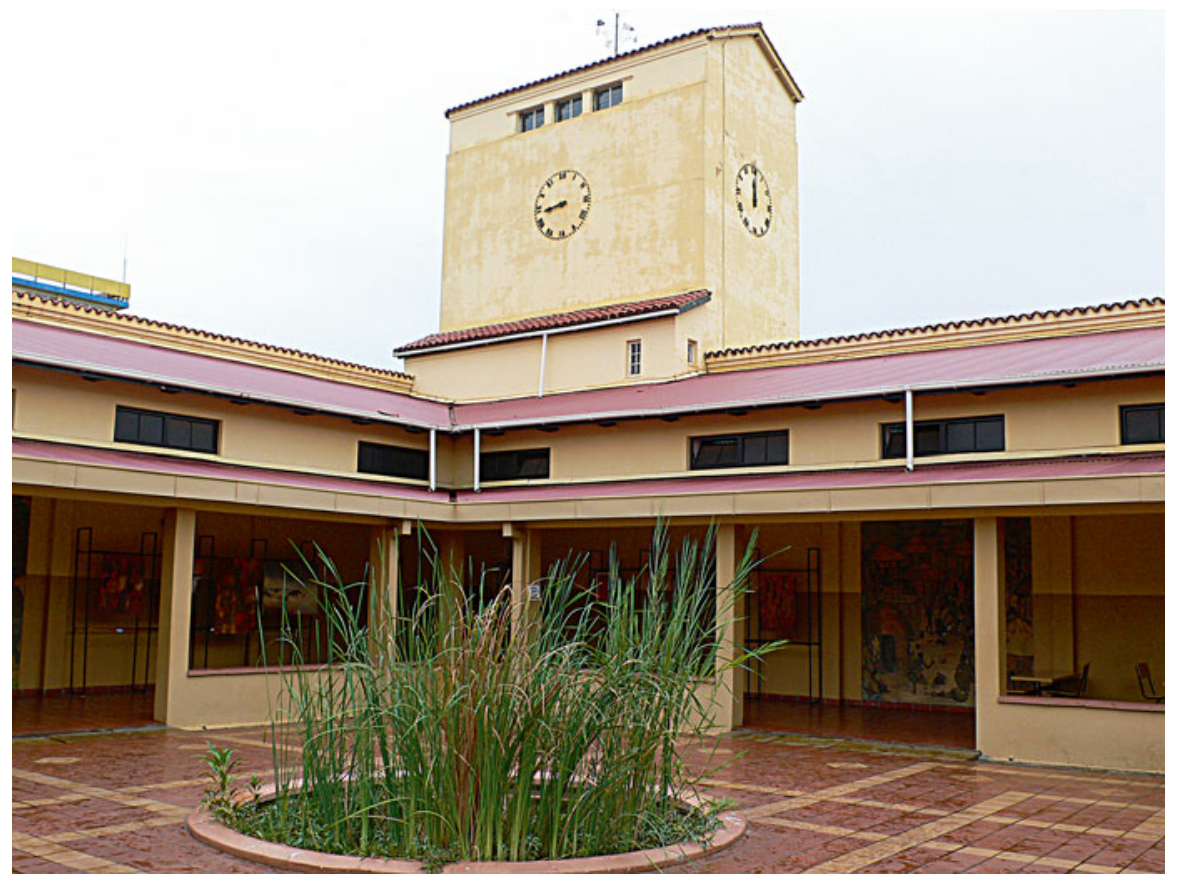

Fig. 12 Livingstone Museum in Livingstone

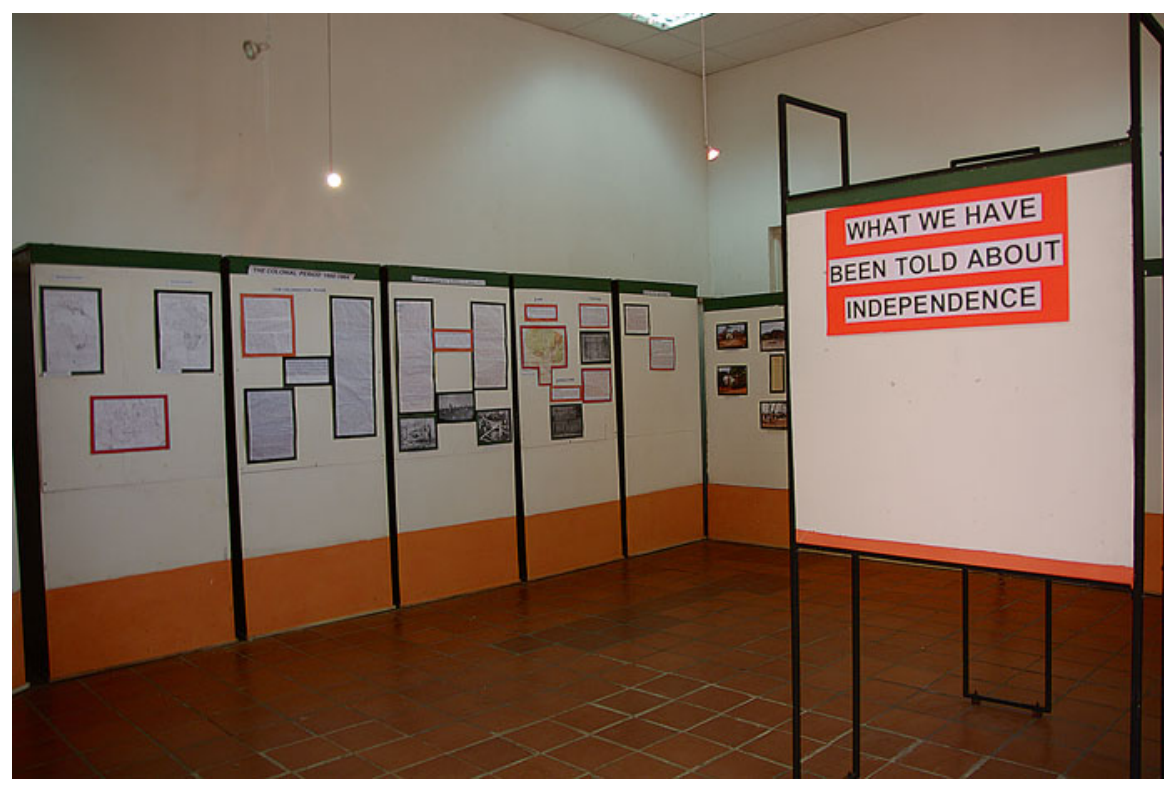

Fig. 13 "What we have been told about Independence" Exhibition at the Livingstone Museum 


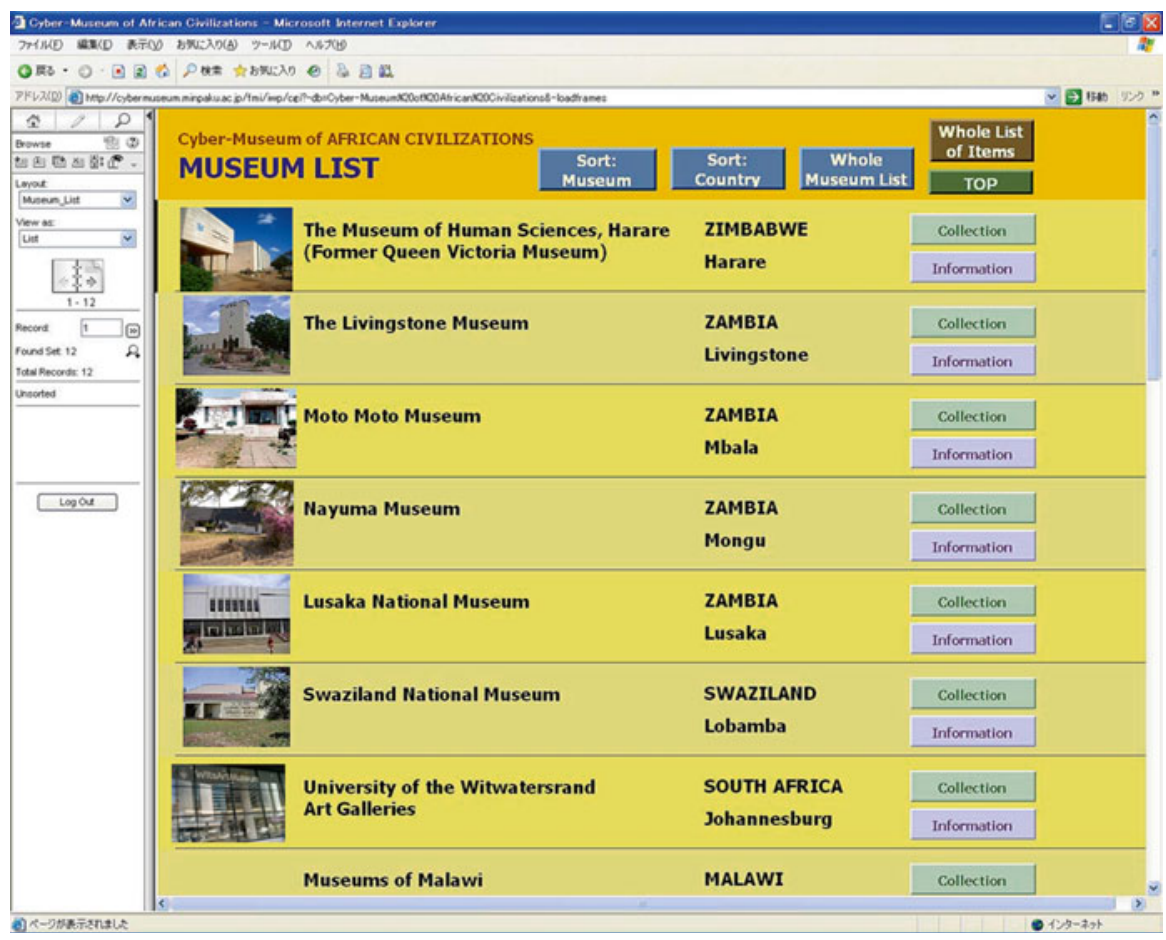

Fig. 14 Cyber-Museum of African Civilizations

\section{Conclusion}

Before concluding, it should be noted here that, if the identity created or strengthened by this movement is narrow-minded, it will result only in creating a nationalistic ideology. The identity museums to be created should be open-minded and those that admit cultural diversity. For this purpose, the networking of museums, both nationally and internationally, is essential.

In Zambia, the National Museums Board based in the capital city Lusaka is supporting the movement of establishing local museums on the one hand, and it is trying to network these movements on the other. I myself am also supporting their activities by connecting the network with the various programs carried out by our museum, the National Museum of Ethnology, Japan.

In this paper, I have introduced a series of museological workshops held in Zambia as follow-up programs to the training course in Japan. To these workshops, people who are involved in constructing community-based museums are also invited for the purpose of sharing knowledge and experience in the field of museology. A database sharing information on the collections of participating museums is also constructed (Fig. 14). Although there are many ethnic groups in Zambia, almost all of them belong to the so-called Bantu-speaking language group, and they share 
many aspects of materials culture. The database can demonstrate the existence of this commonality that crosses national borders. Construction of the database is also a part of our endeavor to foster an open-minded identity. The role of a museum as an instrument for constructing culture and society that is rooted in the relevant community and yet equipped with a sense of open-minded identity will certainly become increasingly vital in the coming age.

The museum has long been considered as a place of representation, preservation, and conservation of the tangible cultural properties of the past. From this viewpoint, there seems little room for museums to contribute to community development. However, the museum is not only a storage of tangible objects of the past, nor just a tourist spot, but a base of accumulation and dissemination of local culture, including knowledge, memory and technology that has been transmitted from one generation to another in the community, and thus, a base for creating people's pride in or identity to the community. Only when people have pride in themselves and their own culture can people challenge and overcome various difficulties. In this sense, museums may well be considered to be a fundamental instrument of community development, and thus development aid.

Open Access This chapter is distributed under the terms of the Creative Commons AttributionNonCommercial 4.0 International License (http://creativecommons.org/licenses/by-nc/4.0/), which permits any noncommercial use, duplication, adaptation, distribution and reproduction in any medium or format, as long as you give appropriate credit to the original author(s) and the source, provide a link to the Creative Commons license and indicate if changes were made.

The images or other third party material in this chapter are included in the work's Creative Commons license, unless indicated otherwise in the credit line; if such material is not included in the work's Creative Commons license and the respective action is not permitted by statutory regulation, users will need to obtain permission from the license holder to duplicate, adapt or reproduce the material.

\section{References}

Corbeil, J.J. 1982. Mbusa: Sacred Emblems of the Bemba. Mbala, Zambia: Moto Moto Museum. Yoshida, Kenji. 1993. Masks and Secrecy among the Chewa. African Arts 24(2): 34-45. 92.

Yoshida, Kenji and John Mack eds. 2008. Preserving the cultural heritage of Africa: Crisis or renaissance? Oxford: James Currey. 
Part VI

Afterword 


\title{
Twenty-Year of Cooperation
}

\author{
Tsuneyuki Morita
}

At the end of this 3-year project (Japan Society for the Promotion of Science (JSPS) Core-to-Core Program "New Horizons in Asian Museums and Museology") to advance the mutual collaboration of museum studies and practices in Asian countries, particularly Mongol, Myanmar, Thailand and Japan, I would like to express my delight at the fruitful gains made through sincere discussions.

Practically speaking, our project got underway 20 years ago, when the first international museology program was organized, featuring collaboration with National Museum of Ethnology, Japan (Minpaku) and the Japan International Cooperation agency (JICA). Three foreign participants at the present meeting, Ms. Jarunee Incherdchai, Mr. Ichinkhorloo Lkhagvasuren, and Ms. Nu Mra Zan, also joined in that program. At the time, some of us were instructors and above the three were students, but we are now warmer friends and colleagues. One of the unofficial purposes of the program and something which I personally expected as head of the steering committee was to cement closer links among museum professionals from various countries. Since that time, some of the seeds you brought back to your home countries have spawned thriving flowers all around the world. The younger members who participated in the same program in recent years surely supported this initiative. Of course, all countries have their own cultural background, so we showed you some ideas and numerous results from our own trial and error approach to use as a reference in your new activities. During the actual 3-day international symposium, we also learned a lot from you and were able to check and review the activities performed over our last 20 years of activities.

Museology only emerged as recently as the second quarter of the twentieth century in Europe and North America, at which time all Asian, African, South

\footnotetext{
T. Morita $(\bowtie)$

National Museum of Ethnology, Senri Expo Park, Suita, Osaka 565-8511, Japan

e-mail:mhf01623@nifty.ne.jp
} 
American and other areas were off limits for discussion in all respects. This might be inevitable, because most of those countries were colonies or semi-colonial states of Great Powers - a fact which led to a yawning chasm in international museum standards. So-called global standards only apply to target areas and most of the conditions in other areas were neglected. The museum, particularly in Asian countries, is demanded to find a local standard rather than respecting the "global standard."

We believe that the present project represents a positive trial occasion to reveal our own standard in Asia.

Open Access This chapter is distributed under the terms of the Creative Commons AttributionNonCommercial 4.0 International License (http://creativecommons.org/licenses/by-nc/4.0/), which permits any noncommercial use, duplication, adaptation, distribution and reproduction in any medium or format, as long as you give appropriate credit to the original author(s) and the source, provide a link to the Creative Commons license and indicate if changes were made.

The images or other third party material in this chapter are included in the work's Creative Commons license, unless indicated otherwise in the credit line; if such material is not included in the work's Creative Commons license and the respective action is not permitted by statutory regulation, users will need to obtain permission from the license holder to duplicate, adapt or reproduce the material. 